\author{
UNIVERSIDADE DE SÃO PAULO \\ FACULDADE DE FILOSOFIA, LETRAS E CIÊNCIAS HUMANAS \\ DEPARTAMENTO DE HISTÓRIA \\ PROGRAMA DE PÓS-GRADUAÇÃO EM HISTÓRIA ECONÔMICA
}

FAMÍLIAS ESCRAVAS EM ANGRA DOS REIS, 1801-1888

Marcia Cristina Roma de Vasconcellos

São Paulo

2006 


\author{
UNIVERSIDADE DE SÃO PAULO \\ FACULDADE DE FILOSOFIA, LETRAS E CIÊNCIAS HUMANAS \\ DEPARTAMENTO DE HISTÓRIA \\ PROGRAMA DE PÓS-GRADUAÇÃO EM HISTÓRIA ECONÔMICA
}

\title{
FAMÍLIAS ESCRAVAS EM ANGRA DOS REIS, 1801-1888
}

Marcia Cristina Roma de Vasconcellos

\begin{abstract}
Tese apresentada ao Programa de PósGraduação em História Econômica da Faculdade de Filosofia, Ciências e Letras da Universidade de São Paulo, para obtenção do título de Doutora.
\end{abstract}

Orientador: Professor Doutor José Flávio Motta

São Paulo

2006 


\section{DEDICATÓRIA}

Para a minha avó Olga (em memória), minha mãe Vilma e meu filho Leon. 


\section{AGRADECIMENTOS}

Muitas foram as pessoas que colaboraram direta ou indiretamente para a realização deste estudo. Tentarei não esquecer de ninguém.

Começo pela universidade: em primeiro lugar, agradeço ao meu orientador, Professor Doutor José Flávio Motta, por sua paciência e suas leituras; assim como, aos Professores Doutores Nelson Nozoe e Horácio Gutiérrez, que participaram do exame de qualificação e ofereceram preciosas contribuições. E, também, aos funcionários da Secretaria da Pós-graduação em História.

Sou grata ao Conselho Nacional de Ciência e Tecnologia, CNPq, pela concessão de uma bolsa de pesquisa, sem a qual seria difícil realizar esta reflexão.

Agradeço aos funcionários da Biblioteca Nacional, do Instituto Brasileiro de Geografia e Estatística (IBGE), da Igreja de Jacuecanga e do Convento do Carmo.

Em particular, agradeço aos funcionários do Museu da Justiça do Estado do Rio de Janeiro, representados pelo Sr. Miro. Sem a colaboração, a solidariedade e a amizade de todos, seria impossível realizar a pesquisa. Seria impossível, mesmo! A vocês, do Museu, muito obrigada. Vocês são um grande exemplo de respeito à memória e de compaixão. Ao Miro, a Margareth, a Iamara, a Tereza e ao Frederico, agradeço por tudo.

Sobre as pessoas do meu convívio, devo muito à minha mãe. Foi ela quem me ajudou a tornar-me mãe, em meio aos registros de batismo, de casamento... foi ela quem me auxiliou até a coletar os inventários, quando eu estava quase dando à luz. Ela foi o meu amparo, dando-me segurança emocional e psicológica. Junto à ela, em meio aos acontecimentos da vida, reencontrei o Paulo. Ele, sem saber, deu-me força e coragem para que eu pudesse terminar este estudo. Sem seu amor, amizade e companheirismo, eu teria parado no meio. Ao meu filho Leon, peço desculpas pelo meu “isolamento", mas saiba que sempre estive próxima em pensamento.

Destaco minhas dívidas para com Lília Laranjeira Telles da Silva, avó do Leon, pela hospedagem em Angra, pelo carinho e ajuda durante o levantamento dos registros paroquiais.

Agradeço a minha irmã, Beth, e a minha sobrinha, Carol, que me ajudaram na digitação dos documentos. Ao meu irmão, Roberto, pelos conselhos e incentivos, via 
“interurbano”. Ao meu sobrinho, Felipe, pela assistência nas horas em que o computador deu “pane”. Sou grata a Ana Luzia pela revisão do português. Valeu!

Sou grata, também a BSGI (Associação Brasil - Soka Gakkai Internacional) e aos novos amigos, membros daquela organização, em particular, Neide, Marcos e Bianca, por suas palavras de encorajamento.

Em meio a tantos eventos ocorridos nesses quatro anos, sinto apenas não poder contar com a presença de minha avó Olga.

Dedico este trabalho a minha avó Olga (em memória), minha mãe Vilma e meu filho Leon. 


\section{SUMÁRIO}

Índice

p. 8

Índice das Tabelas

p. 10

Índice de Figuras

p. 17

Resumo

p. 18

Abstract

p. 19

Introdução

p. 20

Parte I-Economia e demografia de Angra dos Reis no século XIX

Introdução

p. 32

Capítulo 1-Histórias de Angra dos Reis

p. 34

Capítulo 2-Evolução da população livre e escrava

p. 57

Capítulo 3-Mapeamento econômico e estrutura de posse de escravos

p. 74

Parte II-Famílias escravas e seus graus de legitimidade

Introdução

p. 101

Capítulo 4-Famílias nucleares e famílias matrifocais

p. 104

Capítulo 5-Casamento entre os escravos

p. 113

Capítulo 6-Mães casadas e mães solteiras

p. 132

Parte III-Compadrio entre escravos

Introdução

p. 142

Capítulo 7-Notas sobre o batismo

p. 144

Capítulo 8-Batismo de escravos adultos

p. 150

Capítulo 9-Batismo de crianças escravas e ingênuas

p. 164

Capítulo 10-Os pais espirituais

p. 193 
Parte IV-Estabilidade das famílias escravas

Introdução

p. 211

Capítulo 11-As famílias extensas

p. 213

Capítulo 12- Os laços parentais no momento da partilha dos bens

p. 224

Conclusão

p. 234

Anexos

p. 237

Apêndice

p. 249

Referências Bibliográficas

p. 255 


\section{ÍNDICE}

Introdução

p. 20

Parte I-Economia e demografia de Angra dos Reis no século XIX

Introdução

p. 32

Capítulo 1-Histórias de Angra dos Reis

p. 34

Capítulo 2-Evolução da população livre e escrava

p. 57

Capítulo 3-Mapeamento econômico e estrutura de posse de escravos

p. 74

Parte II-Famílias escravas e seus graus de legitimidade

Introdução

p. 101

Capítulo 4-Famílias nucleares e famílias matrifocais

p. 104

Capítulo 5-Casamento entre os escravos

p. 113

Capítulo 6-Mães casadas e mães solteiras

p. 132

Parte III-Compadrio entre escravos

Introdução

p. 142

Capítulo 7-Notas sobre o batismo

p. 144

Capítulo 8-Batismo de escravos adultos

p. 150

Capítulo 9-Batismo de crianças escravas e ingênuas

p. 164

Capítulo 10-Os pais espirituais

p. 193

Parte IV-Estabilidade das famílias escravas

Introdução

p. 211

Capítulo 11-As famílias extensas

p. 213

Capítulo 12- Os laços parentais no momento da partilha dos bens

p. 224

Conclusão

p. 234

Anexos

p. 237 
Apêndice

p. 249

Referências Bibliográficas

p. 255 


\section{ÍNDICE DAS TABELAS}

TABELA 1-Saída de barcos do litoral sul-fluminense em direção ao Rio de Janeiro, 1827-1888

p. 45

TABELA 2-Cargas transportadas pelos barcos saídos do litoral sul-fluminense em direção ao Rio de Janeiro, 1827-1888

p. 46

TABELA 3-Tipos de embarcações provenientes do litoral sul-fluminense rumo ao Rio de Janeiro, 1827-1888

p. 53

TABELA 4-População livre e escrava existente nas freguesias de Angra dos Reis, 18401872

p. 58

TABELA 5-Taxas de crescimento anual das populações livre e escrava existentes nas freguesias de Angra dos Reis, 1840-1872

p. 60

TABELA 6-Razão de sexo da população escrava existente nas freguesias de Angra dos

Reis, 1840-1872

p. 64

TABELA 7-Razão de sexo da população escrava entre 15 e 40 anos existente nas freguesias de Angra dos Reis, 1872

p. 65

TABELA 8-Origem dos escravos localizados nas freguesias de Angra dos Reis, 1856 e 1872

p. 66

TABELA 9-Procedências dos escravos crioulos existentes nas freguesias de Angra dos Reis, 1872

p. 67

TABELA 10-Faixas etárias dos escravos existentes nas freguesias de Angra dos Reis, 1856

p. 68

TABELA 11-Faixas etárias dos escravos existentes nas freguesias de Angra dos Reis, 1872 p. 69

TABELA 12-Número de propriedades, de escravos e de ingênuos constantes nos inventários post-mortem, por subperíodos. Angra dos Reis, 1800-1888

p. 74

TABELA 13-Faixa de tamanho de propriedades, por subperíodos. Angra dos Reis, 18001888

p. 77

TABELA 14-Atividades localizadas nos inventários de Angra dos Reis, entre 1800 e 1888

p. 80 
TABELA 15-Atividades citadas nos inventários de Angra dos Reis de escravistas e não escravistas, 1800-1888

p. 82

TABELA 16-Relação de inventariados que possuíam apólices, eram credores e complementavam suas rendas com aluguéis de imóveis ou de escravos. Angra dos Reis, 1800-1888

p. 84

TABELA 17-Relação de inventariados escravistas e não escravistas que possuíam apólices, eram credores e complementavam suas rendas com aluguéis de imóveis ou de escravos. Angra dos Reis, 1800-1888

p. 85

TABELA 18-Cultivos indicados nos inventários de Angra dos Reis, entre os anos de 1800 e 1888 p. 87

TABELA 19-Participação das dívidas passivas sobre o patrimônio dos inventariados por faixas de tamanho de propriedades. Angra dos Reis, 1800-1888 p. 89 TABELA 20-Número de escravos por faixas de tamanho de propriedades e por subperíodos. Angra dos Reis, 1800-1888

TABELA 21-Razão de sexo dos escravos inventariados por subperíodos. Angra dos Reis, 1800-1888

p. 93

TABELA 22-Razão de sexo dos escravos inventariados por faixas de tamanho de propriedades e por subperíodos. Angra dos Reis, 1800-1888 p. 93 TABELA 23-Faixas etárias dos escravos por subperíodos. Angra dos Reis, entre 1800 e 1888 p.94

TABELA 24-Idades dos escravos por faixas de tamanho de propriedades e por subperíodos. Angra dos Reis, 1800-1888

p. 95

TABELA 25-Origem dos escravos por faixas de tamanho de propriedades e por subperíodos. Angra dos Reis, 1800-1888

p. 96

TABELA 26-Atividades exercidas pelos escravos homens, segundo os inventários, por subperíodos. Angra dos Reis, 1800-1888 p. 97 TABELA 27-Atividades exercidas pelos escravos homens, segundo os inventários, por faixas de tamanho de propriedades. Angra dos Reis, 1800-1888 p. 98 TABELA 28-Atividades exercidas pelas escravas mulheres, segundo os inventários, por subperíodos. Angra dos Reis, 1800-1888 p. 99 
TABELA 29-Atividades exercidas pelas escravas mulheres, segundo as faixas de tamanho de propriedades. Angra dos Reis, 1800-1888

p. 99

TABELA 30-Frequiência de famílias nucleares e matrifocais presentes nos inventários. Angra dos Reis, 1800-1888 p. 105

TABELA 31-Freqüência de escravos envolvidos em laços familiares nucleares e matrifocais, presentes nos inventários. Angra dos Reis, 1800-1888 p. 107 TABELA 32-Freqüência de escravos envolvidos em laços familiares nucleares e matrifocais, presentes nos inventários, sobre o total de escravos avaliados. Angra dos Reis, 1800-1888 p. 108 TABELA 33-Freqüência de famílias nucleares e matrifocais por subperíodos e faixas de tamanho de propriedades. Angra dos Reis, 1800-1888 p. 109 TABELA 34-Freqüência de escravos envolvidos em famílias nucleares e matrifocais por subperíodos e faixas de tamanho de propriedades. Angra dos Reis, 1800-1888 p. 112 TABELA 35-Freqüência de casamentos por subperíodos. Angra dos Reis, entre 1830 e 1886 p. 118

TABELA 36-Freqüência de casamentos coletivos e simples por subperíodos. Angra dos Reis, 1830-1886 p. 120 TABELA 37-Locais das cerimônias de casamento por subperíodos. Angra dos Reis, 1830-1886

p. 121

TABELA 38-Horários das cerimônias de casamento por subperíodos. Angra dos Reis, 1830-1886

p. 122

TABELA 39-Sazonalidade das cerimônias de casamentos por subperíodos. Angra dos Reis, 1830-1886

p. 123

TABELA 40-Origens dos noivos por subperíodos. Angra dos Reis, entre os anos de 1830 e 1886 p. 127

TABELA 41-Origens das mães solteiras de crianças escravas e ingênuas batizadas por subperíodos. Angra dos Reis, 1805-1888

p. 132

TABELA 42-Concepção das crianças escravas e ingênuas ilegítimas por subperíodos. Angra dos Reis, 1830-1886 p. 136

TABELA 43-Concepção das crianças escravas e ingênuas legítimas por subperíodos. Angra dos Reis, 1830-1886 p. 137 
TABELA 44-Faixas etárias dos batizandos por subperíodos. Angra dos Reis, entre os anos de 1805 e 1888

TABELA 45-Sazonalidade das cerimônias de batismos de adultos por subperíodos. Angra dos Reis, 1805-1871

p. 150

TABELA 46-Sexo dos adultos batizados por subperíodos. Angra dos Reis, entre os anos de 1805 e 1871

p. 151

TABELA 47-Procedências dos adultos africanos batizados do sexo masculino por subperíodos. Angra dos Reis, 1805-1871

p. 153

TABELA 48-Procedências dos adultos africanos batizados do sexo feminino por subperíodos. Angra dos Reis, 1805-1871

p. 154

TABELA 49-Situação social de padrinhos de adultos batizados por subperíodos. Angra dos Reis, 1805-1871

p. 155

TABELA 50-Senhores de padrinhos escravos e de adultos batizados por subperíodos. Angra dos Reis, 1805-1871

p. 157

TABELA 51-Situação social de madrinhas de adultos batizados por subperíodos. Angra dos Reis, 1805-1871

p. 159

TABELA 52-Representações religiosas presentes nos batismos de adultos por subperíodos. Angra dos Reis, 1805-1871

p. 160

TABELA 53-Senhores de madrinhas escravas e de adultos batizados por subperíodos. Angra dos Reis, 1805-1871

p. 161

TABELA 54-Legitimidade das crianças escravas e ingênuas batizadas por subperíodos. Angra dos Reis, 1805-1888

p. 165

TABELA 55-Sazonalidade das cerimônias de batismos de crianças e ingênuas legítimas por subperíodos. Angra dos Reis, 1805-1888

p. 166

TABELA 56-Sazonalidade das cerimônias de batismos de crianças e ingênuas ilegítimas por subperíodos. Angra dos Reis, 1805-1888

p. 167

TABELA 57-Sexo das crianças escravas e ingênuas legítimas batizadas por subperíodos. Angra dos Reis, 1805-1888 p. 168 TABELA 58-Sexo das crianças escravas e ingênuas ilegítimas batizadas por subperíodos. Angra dos Reis, 1805-1888 p. 168 
TABELA 59-Idades em meses das crianças escravas e ingênuas legítimas quando do batismo por subperíodos. Angra dos Reis, 1805-1888

p. 169

TABELA 60-Idades em meses das crianças escravas e ingênuas ilegítimas quando do batismo por subperíodos. Angra dos Reis, 1805-1888

p. 170

TABELA 61-Situação social de padrinhos de crianças escravas e ingênuas legítimas por subperíodos. Angra dos Reis, 1805-1888

p. 172

TABELA 62-Situação social de padrinhos de crianças escravas e ingênuas ilegítimas por subperíodos. Angra dos Reis, 1805-1888

p. 173

TABELA 63-Senhores de padrinhos escravos e de pais de crianças escravas e ingênuas legítimas batizadas por subperíodos. Angra dos Reis, 1805-1888

p. 175

TABELA 64-Senhores de padrinhos escravos e de mães de crianças escravas e ingênuas ilegítimas batizadas por subperíodos. Angra dos Reis, 1805-1888

p. 176

TABELA 65-Origens dos pais de crianças escravas e ingênuas legítimas e dos padrinhos por subperíodos. Angra dos Reis, 1805-1888

p. 178

TABELA 66-Origens das mães de crianças escravas e ingênuas ilegítimas e dos padrinhos por subperíodos. Angra dos Reis, 1805-1888

p. 179

TABELA 67-Situação social de madrinhas de crianças escravas e ingênuas legítimas por subperíodos. Angra dos Reis, 1805-1888

p. 180

TABELA 68-Representações religiosas presentes nos batismos de crianças escravas e ingênuas legítimas por subperíodos. Angra dos Reis, 1805-1888

p. 181

TABELA 69-Situação social de madrinhas de crianças escravas e ingênuas ilegítimas por subperíodos. Angra dos Reis, 1805-1888

p. 182

TABELA 70-Representações religiosas presentes nos batismos de crianças escravas e ingênuas ilegítimas por subperíodos. Angra dos Reis, 1805-1888

p. 184

TABELA 71-Senhores de madrinhas escravas e de pais crianças escravas e ingênuas legítimas batizadas por subperíodos. Angra dos Reis, 1805-1888

p. 185

TABELA 72-Senhores de madrinhas escravas e de mães de crianças escravas e ingênuas ilegítimas batizadas por subperíodos. Angra dos Reis, 1805-1888

p. 187

TABELA 73-Origens dos pais de crianças escravas e ingênuas legítimas e das madrinhas por subperíodos. Angra dos Reis, 1805-1888

p. 188 
TABELA 74-Origens das mães de crianças escravas e ingênuas ilegítimas e das madrinhas por subperíodos. Angra dos Reis, 1805-1888

p. 189

TABELA 75-Nomes de batizandos crianças e ingênuos legítimos do sexo masculino, pais, mães, padrinhos e madrinhas por subperíodos. Angra dos Reis, 1805-1888 p. 194 TABELA 76-Nomes de batizandos crianças e ingênuos legítimos do sexo feminino, pais, mães, padrinhos e madrinhas por subperíodos. Angra dos Reis, 1805-1888 p. 194 TABELA 77-Nomes de batizandos crianças e ingênuos ilegítimos do sexo masculino, mães, padrinhos e madrinhas por subperíodos. Angra dos Reis, 1805-1888 p. 195 TABELA 78-Nomes de batizandos crianças e ingênuos ilegítimos do sexo feminino, mães, padrinhos e madrinhas por subperíodos. Angra dos Reis, 1805-1888 p. 196 TABELA 79-Freqüência de afilhados por padrinhos. Angra dos Reis, entre os anos de 1805 e 1888

TABELA 80-Freqüência de afilhados por madrinhas. Angra dos Reis, entre os anos de 1805 e 1888 p. 200

TABELA 81-Contato entre plantéis no momento do batismo, oferecendo padrinhos. Angra dos Reis, 1805-1888

p. 201

TABELA 82-Contato entre plantéis no momento do batismo, oferecendo madrinhas. Angra dos Reis, 1805-1888

p. 206

TABELA 83-Freqüência de escravos envolvidos em famílias nucleares, matrifocais, fraternais e extensas por subperíodos e faixas de tamanho de propriedades. Angra dos Reis, 1800-1888

p. 222

TABELA 84-Freqüência de separação de famílias nucleares e de seus parentes na partilha, por subperíodos. Angra dos Reis, 1800-1888 p. 226

TABELA 85-Freqüência de separação de famílias matrifocais e de seus parentes na partilha, por subperíodos. Angra dos Reis, 1800-1888 p. 227 TABELA 86-Tipo de separações ocorridas entre as famílias nucleares na partilha, por faixa de tamanho de propriedades e por subperíodos. Angra dos Reis, 1800-1888 p. 228 TABELA 87-Tipo de separações ocorridas entre as famílias matrifocais na partilha, por faixa de tamanho de propriedades e por subperíodos. Angra dos Reis, 1800-1888 p. 229 TABELA 88-Freqüência de separação de famílias fraternas e de seus parentes na partilha, por subperíodos. Angra dos Reis, 1800-1888 p. 231 
TABELA 89-Freqüência de separação de famílias extensas e de seus parentes na partilha, por subperíodos. Angra dos Reis, 1800-1888

p. 232 


\section{ÍNDICE DE FIGURAS}

FIGURA 1-Angra dos Reis no século XX

p. 37

FIGURA 2-Caracterização econômica do Rio de Janeiro, 1780-1840

p. 51

FIGURA 3-Contatos entre as propriedades oferecendo padrinhos

p. 204

FIGURA 4-Contatos entre as propriedades oferecendo madrinhas

p. 208

FIGURA 5-Família de Eva crioula, 1835

p. 215

FIGURA 6-Família de Catarina africana, 1862

p. 216

FIGURA 7-Família de Isabel crioula, 1871

p. 217

FIGURA 8-Família de Maria crioula, 1882

p. 219

FIGURA 9-Família de Maria africana

p. 220 


\section{RESUMO}

Em Angra dos Reis, a população local, na primeira metade do século XIX, dedicava-se ao autoconsumo e ao mercado interno. Desenvolveram-se o comércio e os transportes, pois seus portos foram um dos principais meios de escoamento do café do vale do Paraíba fluminense e paulista, dinamizando a vida econômica.

Entretanto, ao longo da segunda metade do Oitocentos, instalou-se, gradativamente, um quadro de transformações econômicas e demográficas, resultante do término do tráfico de escravos e da diminuição do movimento portuário em função da chegada da estrada de Ferro D. Pedro II ao vale.

Diante desse panorama, analisamos as características e o grau de estabilidade das famílias escravas, entre 1801 e 1888, e de que forma foram atingidos na segunda metade do século XIX. Tais reflexões tiveram como parâmetro os dois núcleos básicos familiares: os formados pelo casal sem ou com filhos e aqueles constituídos por mães solteiras e filhos. As fontes principais utilizadas foram os inventários post-mortem e os registros de batismo e de casamento. Avaliamos, também, temas como, o matrimônio, a maternidade, o intercurso sexual, as famílias extensas, as famílias fraternas e o compadrio. Realizamos um mapeamento econômico, verificando o evolver da estrutura de posse de escravos e os tipos de produções encetados; bem como o perfil demográfico da população livre e cativa. Para isso, manuseamos documentos como, o Jornal do Commércio, o Almanak Laemmert, os recenseamentos de 1840, 1850 e de 1856, o Censo Nacional 1872 e os relatos de viajantes e cronistas.

Portanto, com o presente estudo, desejamos contribuir para a produção do conhecimento sobre a escravidão e o litoral sul-fluminense, trazendo à tona a história das famílias cativas.

\section{PALAVRAS-CHAVE:}

Famílias escravas, demografia histórica, estrutura de posse de escravos, litoral sulfluminense e século XIX. 


\begin{abstract}
In Angra dos Reis, in the first half of the XIX century, the local population was devoted to the selfconsumption and internal market. The commerc and transportation grew, as its ports were one of the main means of outlet of the coffee from the vleey of the Paraiba river in Rio de Janeiro and São Paulo, making the economy more dynamic.

However, during the second half of XIX century, a panel of economic and demographic transformations was gradually settedresulting from the end of slave-traffic and the decreasing of the port activity due to the arrival of the D. Pedro II Raiboad to the valley.

In face of this panorama, we analysed the characteristics and the degree of stability of the slave families between 1801 and 1888 and in which way they were affected in the second half of the XIX century. Such reflexions had as a paramater the two basic nuclei of family: the ones composed of the compe with or without children and those composed of urmarried mothers and their children. Post-mortem inventories and baptism and weddingregisters were the main sources used. We also evaluated themes like the wedding, the motherhood, the sexual intercourse, the big families yhe fraternal families and the baptism, We carried out a map of the economy verifying the evolving of the structure of slaves ownership, the types of productions initiated, as well as the demographic profile of the free and captive populations. For this, we handled docunments like the Jornal do connercio, the Almmanak Laemmert, the 1840, 1850 and 1856 census, the 1872 National Census and the reports of travelers and chroniclers.

Therefore, with the present study, we wish to contribute to the production of Knowledge about slavery and the coast in the south osf Rio de Janeiro, bringing the history of the captive families to light.
\end{abstract}

KEY WORDS:

Slave families, historical demography, slaves owonership structure, coast of the south of Rio de Janeiro and XIX century. 


\section{INTRODUÇÃO}

Os trabalhos sobre escravidão, até a década de 1970, consideravam que a promiscuidade fazia parte do dia-a-dia do cativo. Anomalia resultante ou do estágio de desenvolvimento do negro (RODRIGUES, 1988) ou do próprio sistema - por ter retirado o africano de seu ambiente social e familiar, colocando-o numa nova realidade hostil, junto a pessoas estranhas (FREYRE, 1992) — ou das condições de cativeiro que eram adversas.

Outros estudos destacaram o desequilíbrio entre os sexos, decorrência da preferência, no tráfico Atlântico, por homens que, teoricamente, seriam os mais aptos ao serviço do eito; o desinteresse senhorial, já que a existência da família poderia dificultar a venda da escravaria; e o desinteresse dos próprios cativos, que procuravam evitar a procriação e, logo, a escravização dos filhos (cf. GORENDER, 1992; COSTA, 1998; CARDOSO, 1962).

Essas teses começaram a ser reavaliadas nos últimos trinta anos, quando, então, os laços familiares tornaram-se tema de pesquisas. Segundo Faria (1997), tal movimento inspirou-se em estudos norte-americanos (cf. GENOVESE, 1988, GUTMAN, 1976) e associou-se a uma reformulação da visão sobre o escravo. Não mais, somente agente histórico na fuga, na revolta ou no roubo, mas no seu dia-a-dia, ao lado da difusão do emprego de fontes paroquiais (casamento e batismo), cartorárias (inventários postmortem), censos populacionais, processos criminais e releituras críticas de relatos de viajantes e cronistas.

Pesquisas de demografia histórica também forneceram importantes contribuições, trazendo informações sobre a estrutura de posse de escravos e as características das populações livre e escrava. Tais trabalhos mostraram alguns padrões familiares e domiciliares e criticaram a noção de família patriarcal como modelo de família brasileira, embora não invalidando sua existência no Nordeste (MOTTA, 1999b).

No tocante as famílias escravas, inicialmente, foram analisadas àquelas identificadas no inventário de 1791, referente à escravaria da Fazenda Santa Cruz, no Rio de Janeiro, RJ (GRAHAM, 1979), e em Campinas, São Paulo (SLENES, 1976; SLENES, 1987); posteriormente, os registros de casamento passaram a ser minuciosamente 
analisados. Destacamos, entre outros trabalhos, o de uma Paróquia em Vila Rica, em Minas Gerais, entre 1727 e 1826 (LUNA \& COSTA, 1981) e o de 13 localidades de São Paulo, nos anos de 1776, 1804 e 1829 (LUNA, 1990). Demais pesquisas realizadas envolveram, dentre outras, localidades como Paraíba do Sul, no Rio de Janeiro, entre 1830 e 1872 (FRAGOSO \& FLORENTINO, 1987); o nordeste colonial e açucareiro (SCHWARTZ, 1995); e Santana do Parnaíba, em São Paulo, entre fins do século XVIII e princípios do seguinte (METCALF, 1990).

Os estudiosos concluíram que, em meio a dificuldades, como a desproporção entre os sexos, existiram espaços menos adversos para a formação de famílias legais. Logo, havia maior presença de crianças legítimas e de cativos casados e viúvos, por exemplo, entre propriedades médias e grandes de Campinas (SLENES, 1987, p. 218), de Bananal, em São Paulo, nos anos de 1801, 1817 e 1829 (MOTTA, 1999a, p. 304-308) e de Lorena, também em São Paulo, no ano de 1801 (COSTA, SLENES \& SCHWARTZ, 1987, p. 254).

Observaram que, no Brasil, havia um predomínio de casamentos "intrapropriedades" (cf. SLENES, 1999; SLENES, 1987; MOTTA, 1999a; METCALF, 1990; SCHWARTZ, 1995). Por conseguinte, em escravarias maiores, os cativos teriam mais chances em localizar parceiros (SLENES, 1987). O contrário também era verdade, quanto menor a propriedade, maior a freqüência de mães solteiras e, logo, de crianças "naturais".

Alguns trabalhos verificaram que muitas famílias resistiram aos momentos considerados mais delicados, como a partilha, quando da abertura do inventário do proprietário - tendência encontrada, entre outros trabalhos, para o agro fluminense entre 1790 e 1850 (FLORENTINO \& GÓES, 1997) e para Campinas (SLENES, 1999; ROCHA, 1999) - e a venda - por exemplo, em Paraíba do Sul (FRAGOSO \& FORENTINO, 1987, p. 164-165). Assim sendo, havia estabilidade familiar, garantindo, inclusive, a presença de famílias extensas, formadas por três gerações, e incluindo até o compadrio, considerado como parentesco fictício (cf. SCHWARTZ, 1995; NEVES, 1990; GÓES, 1993; FERREIRA, 2000).

Portanto, o reconhecimento da presença e relativa estabilidade das famílias escravas e, conseqüentemente, a descrença de que a sociedade escravista fosse 
caracterizada pela promiscuidade foram os grandes pontos em comum dessas pesquisas. Porém, existiram controvérsias no que diz respeito ao significado daquela instituição.

Para Florentino \& Góes (1997), a intensa chegada de africanos, considerados estrangeiros, criava um campo de conflito contornado mediante a criação de laços familiares, quando o desconhecido tornava-se conhecido e, assim, fundando a paz. Desta forma, as famílias auxiliavam na reprodução do sistema escravista, tendo um papel estrutural.

Esta perspectiva foi criticada por Slenes (1997, 1999). Ele acreditava que a família - embora respondesse a uma estratégia senhorial de formação de reféns, tanto dos anseios dos escravos quanto dos proprietários — apresentou-se como espaço por meio do qual experiências e memórias eram transmitidas. Os grupos parentais facilitavam o aparecimento de autonomia entre os cativos e tinham uma função “desestabilizadora”.

Ao contrário de estar relacionada à vivência do cativeiro, Castro (1995), a sua vez, considerava que, à medida que favoreciam a obtenção de roças e moradias separadas, os escravos envoltos em laços familiares adquiriam certo destaque junto à escravaria e acabavam vivenciando uma aproximação com o mundo dos livres.

Os dados até aqui apresentados baseavam-se, geralmente, em estudos de áreas que possuíam uma atividade econômica fortemente ligada ao mercado externo ${ }^{1}$. Contudo, as pesquisas que têm sido realizadas não se limitam a esse contexto, ilustrado, em especial, pelas regiões paulistas e fluminenses em meio à expansão da cafeicultura.

De fato, alguns trabalhos sobre Minas Gerais, Paraná e Piauí confirmaram a existência e a estabilidade dos laços familiares entre os escravos, apresentando, inclusive, novas nuances. Estas foram verificadas por pesquisas sobre áreas com uma ligação relativamente fraca com a exportação. Mostrou-se, por meio da observação da razão de sexo, da freqüência de crianças, do perfil da pirâmide etária, e da razão crianças/mulheres na faixa etária reprodutiva, que a reprodução natural positiva foi possível entre os cativos.

Segundo Paiva (1996), Minas Gerais, no Oitocentos, poderia ser dividida entre áreas onde a importação de escravos era o fator central de reposição de mão-de-obra, em outras, em que se combinava com nascimentos, e aquelas nas quais predominava a

\footnotetext{
${ }^{1}$ Exceções: Bananal, em 1801, estudado por Motta (1999a) e Lorena, em 1801, visto por Costa, Slenes \& Schwartz (1987).
} 
reprodução natural. Esta teria campo fértil em localidades mineiras de economia pouco dinâmica, como o Sertão do Alto São Francisco, Paracatu, Sertão, Minas Novas, Extremo Noroeste e Sertão do Rio Doce, visto que a razão de sexo seria baixa, o mesmo se dando com o número de africanos, e maior proporção de cativos com até 14 anos; ou em algumas áreas de economia ativa ou mediana que apresentassem exploração e condições de trabalho menos intensas.

Tendo como base de análise a condição econômica de Mariana, foram estudadas as famílias escravas, a reprodução das propriedades e a estabilidade daquelas relações, entre 1850 e 1888 (TEIXEIRA, 2001). Dentre as demais áreas de Minas Gerais analisadas, incluiu-se, também, Montes Claros, no norte, considerada de economia pouco intensa, entre 1830 e 1870. A considerável presença de crianças e mulheres, a razão de sexo tendente ao equilíbrio e à diminuição da idade mediana, presentes entre os escravos nascidos no Brasil, desde 1830, foram considerados indícios de que o crescimento populacional passava pela reprodução natural; informação confirmada mediante elevadas taxas brutas de natalidade (BOTELHO, 1998b, p. 216-219).

A população senhorial de Paracatu, no noroeste, e Santo Antônio do Monte, Patos e Dores da Marmelada, no oeste mineiro, entendidas como áreas de economias diversificadas e destinadas ao mercado interno, além de ter contado com as aquisições via compra de escravos, também se beneficiou da reprodução natural positiva. A afirmação baseou-se nos dados seguintes: entre 1831-1832, a razão de sexo era baixa sendo que, levando-se em conta somente os nascidos no Brasil, havia um equilíbrio entre todas as faixas etárias; a freqüência de crianças, com até 14 anos, girava em torno dos 30,0\%, sendo, predominantemente, nascidas no Brasil; e a razão de crianças/mulheres, considerando-se aquelas com zero a nove anos e mulheres com 15 a 49 anos, era de 894 (PAIVA \& LIBBY, 1995, p. 220). Entre 1831-1832 e 1873-1875, a razão de sexo diminuiu; as crianças, todas brasileiras, corresponderam a $32,6 \%$ e, embora tenha diminuído em relação a 1831-1832, a razão crianças/mulheres manteve-se relativamente alta, em 734 (PAIVA \& LIBBY, 1995, p. 226).

Campanha, no sul de Minas Gerais, onde conviviam atividades agrícolas e têxteis, além de destilarias e variado comércio, também foi estudada. Em 1831, a área possuía uma população escrava em torno de $29 \%$, sendo que $46 \%$ eram africanos, grupo 
responsável pelo maior desequilíbrio sexual ${ }^{2}$ (PAIVA \& KLEIN, 1992, p. 137). Em oposição, entre os nascidos no Brasil, havia um equilíbrio entre os sexos e a elevada razão crianças/mulheres, considerando-se aquelas com zero a nove anos e mulheres de 15 a 44 ou de 15 a 49 anos. Estes informes permitiram que os autores concluíssem que existia reprodução natural, ao lado da reposição de mão-de-obra por meio da importação de escravos (PAIVA \& KLEIN, 1992, p. 148).

No Paraná, caracterizado pela agricultura de subsistência, no litoral, e a pecuária, no planalto, e sem ligação direta com rotas internacionais, predominavam as propriedades com um a quatro escravos. Durante as três primeiras décadas do século XIX, a localidade tinha na reprodução natural uma importante alternativa para o crescimento e reposição dos escravos ${ }^{3}$. Isso foi verificado mediante o equilíbrio entre os sexos, mesmo entre aqueles com 15 a 40 anos, da presença percentualmente significativa de crianças, de uma elevada participação de cativos casados e da intensa presença de escravos nascidos no Brasil. A reprodução natural era um dado na renovação das escravarias, principalmente, nas maiores propriedades, que congregavam um maior número de crianças; contrariamente, à medida que diminuía o número de escravos por propriedades, havia uma tendência crescente dos senhores buscarem cativos no mercado.

Em Magé, no Rio de Janeiro, a população escrava conheceu um crescimento em números absolutos entre 1856 e 1872, que, apesar de não ter sido em todas as freguesias, foi intenso em Guapimirim, apresentando um crescimento na ordem de 117,54\% (SAMPAIO, 1998, p. 123). Paralelamente, ocorreu uma diminuição da razão de sexo, ao lado do aumento da faixa etária infantil, indicando que os nascimentos desempenhavam importante papel como mecanismo de manutenção da escravidão. A reprodução passava pela família, não nuclear ou extensa, mas matrifocal, além de compras realizadas nas áreas limítrofes ${ }^{4}$. Ao mesmo tempo, dois terços dos escravos mantiveram suas famílias após a partilha (SAMPAIO, 1998, p. 132-139).

\footnotetext{
${ }^{2}$ Fator ligado ao predomínio de homens entre os africanos desembarcados no Brasil e o maior percentual de alforrias entre as mulheres. Ver: Klein (1987).

${ }^{3}$ Quadro apontado igualmente para o Piauí (cf. KNOX, 1993).

${ }^{4}$ As famílias nucleares eram formadas pelo casal sem ou com filhos; as famílias matrifocais, por mães com filhos; e as extensas envolveram famílias formadas por mais de duas gerações.
} 
Outra nuance apresentada, quando do estudo de regiões vinculadas ao mercado interno, foi observada por Faria (1998), por ocasião de sua pesquisa sobre Campos dos Goitacazes, no estado do Rio de Janeiro, nos séculos XVII e XVIII. Verificou que "eram os tipos de produção, as localizações das áreas, o tamanho das unidades produtivas e o período que, dependendo de determinadas combinações, influíam nas possibilidades de casamento dos escravos” (FARIA, 1998, p. 323). Por exemplo, áreas com ilegitimidade superior a 66\% eram aquelas próximas a "portos, recebedores de africanos, e de bispados” (FARIA, 1998, p. 323), pois a proximidade do bispado levava à maior interferência da Igreja nas relações entre senhores e cativos, podendo aumentar o controle sobre a venda separadamente de escravos casados, prática censurada pela Igreja.

Num quadro econômico pouco dinâmico incluiu-se Apiaí, em São Paulo, uma vila beneficiada pela mineração no Setecentos, mas esgotada em 1780, conferindo reflexos no comportamento demográfico e econômico, ainda nas primeiras décadas do século XIX.

Motta (2001), em pesquisa sobre a escravaria de uma grande proprietária, constatou intensa presença da estrutura familiar. A estabilidade seria uma característica observada mediante a idade dos pais; o número de filhos e suas idades no ano de 1816; a presença de registros de casamentos de famílias localizadas em 1815 e em 1816; os casos de famílias com três gerações; e a idade da proprietária. Cruzando o inventário de 1819 e as listas nominativas de habitantes de 1820 e de 1824, Motta (2001, p. 14-15) concluiu que, das 24 famílias localizadas, 37,5\% não foram desmembradas, enquanto 58,3\% foram parcialmente e $29,2 \%$ foram totalmente separadas. Das parcial e totalmente desmembradas, houve casos de reordenações e uniões em anos posteriores. O autor também relativizou as separações, visto que famílias que viviam numa vila pequena não deveriam estar em propriedades afastadas.

Famílias escravas existentes numa área de economia pouco ativa foram localizadas na freguesia de Mambucaba, em Angra dos Reis (VASCONCELLOS, 2001, 2002). Em meio a um contexto de transformações econômicas e demográficas caracterizado pela diminuição dos números de escravos e de africanos, ao longo da segunda metade do século XIX — os casamentos baseados pela endogamia por origem, 
na primeira metade do século, foram diminuindo, enquanto as famílias matrifocais ${ }^{5}$ tornaram-se ainda mais representativas, após 1850. Os laços de compadrio que, entre 1830 e 1849, tenderam a ser estabelecidos, predominantemente, com padrinhos e madrinhas livres, envolveram, posteriormente, cativos, cada vez mais, de diferentes propriedades, daí a ampliação de escravarias interligadas via compadrio, chegando a 76,5\% ${ }^{6}$ (VASCONCELLOS, 2001, p. 113-116).

A pesquisa referida, correspondente a nossa dissertação de mestrado, demonstrou que a freguesia, além de apresentar-nos poucas fontes disponíveis, possuía características específicas; pois, era a de menor número populacional, tanto entre livres quanto em escravos e de maior razão de sexo comparativamente ao encontrado para o total de Angra dos Reis, apontando para uma relativa dinâmica das atividades produtivas em Mambucaba.

Propomos, no presente estudo, a análise dos laços formados pelos cativos que viviam em Angra dos Reis, entre 1801 e 1888. Trata-se de uma localidade, pouco explorada pela pesquisa histórica, constituída por caiçaras, que buscavam a sobrevivência da terra. Outros produziam a aguardente. O café era cultivado por muitos, no entanto, devido à umidade e temperatura elevadas da região, era de qualidade duvidosa e, portanto, comercializado no mercado interno. Ao mesmo tempo, foi um dos pólos, mediante diversos portos, do escoamento do café proveniente do vale do Paraíba, fluminense e paulista (PEREIRA, 1977). Como decorrência, foram criados armazéns de café que, em 1859, chegaram a 25, e se instalaram, no município, indivíduos ligados a sua comercialização (CAPAZ, 1996, p. 102). O movimento portuário dinamizou a vida econômica local, ao empregar moradores do litoral, promover o transporte e a venda de excedentes aos homens que subiam e desciam a serra. Mas isso logo se alterou. Em 1864, as linhas da Estrada de Ferro D. Pedro II chegaram a Barra do Piraí; em 1871, a Barra Mansa; e, em 1877, a Queluz, com a conseqüente diminuição do movimento do litoral ${ }^{7}$.

\footnotetext{
${ }^{5}$ As famílias matrifocais, formadas por mães e filhos, foram encontradas nos registros de batismo de crianças "naturais" e nos inventários onde não foram indicados os parceiros das genitoras. Embora possam incluir, no caso da última fonte, casos de mulheres viúvas ou casadas mas sem estar em companhia de seus maridos, acreditamos que grande parte daquelas mulheres eram, efetivamente, solteiras diante da Igreja.

${ }^{6}$ Diferentemente do que fora visto por Andrade (1995, p. 681); e acima dos 59,9\% encontrados por Góes (1993).

${ }^{7}$ Sobre a Estrada de Ferro, ver El-Kareh (1982).
} 
Por conseguinte, as estradas de Ariró e de Mambucaba, que ligavam a serra ao litoral, foram sendo arruinadas pelo mau estado de conservação (CAPAZ, 1996, 203).

Esses dois elementos conjugados conformaram um quadro de transformação econômica (cf. LIMA, 1972; MENDES, 1970), que atingiu a população livre e seus cativos. Houve diminuição do ritmo de crescimento numérico dos livres e grande decréscimo de escravos.

A segunda metade do século XIX foi assinalada, também, por uma série de medidas visando um processo gradual de abolição da escravidão. Esta marcha foi iniciada ainda com o término do tráfico de escravos, em 1850; e seguida pela Lei de 1869 que proibia a separação de famílias escravas, incluindo crianças menores doze anos; a Lei do Ventre Livre, de 1871, que libertava os rebentos nascidos a partir daquela data e criava o Fundo de Emancipação para libertação dos escravos; e a Lei dos Sexagenários, de 1885, tornando libertos todos os cativos acima dos 60 anos.

É nesse contexto que se desenrola o estudo das características e do grau de estabilidade dos laços familiares entre escravos, entre 1801 e 1888.

Buscamos demonstrar que a população escrava que vivia em Angra encontrou espaços a fim de organizar laços de familiaridade; envolvendo, inicialmente, pais e filhos, mas englobando também, compadres e comadres e parentes como avós, tios e sobrinhos. Entretanto, as características das famílias sofreram o impacto das transformações econômicas e demográficas, ocorridas no município, ao longo da segunda metade do século XIX.

Foi uma localidade onde as famílias, formadas por mães solteiras e seus filhos eram predominantes, em vista do grande número de pequenas escravarias. Nelas, a dificuldade na localização de parceiros e o pouquíssimo número de casamentos "interpropriedades” levaram à conformação de laços que não passaram pelo matrimônio, daí resultando o nascimento de crianças “naturais”. Além do tamanho das escravarias, muitos senhores, possivelmente, desestimularam o matrimônio entre seus escravos - a Lei de 1830, que determinava o término do tráfico externo de escravos ${ }^{8}$, fez com que os escravistas começassem a dificultar a oficialização das uniões entre seus escravos,

\footnotetext{
${ }^{8}$ Hoje sabemos que a Lei de 1831 não foi cumprida, mas os homens da época ficaram apreensivos diante da mesma.
} 
visando garantir, caso houvesse necessidade, a venda de um dos cônjuges, prática censurada pela Igreja.

Ao longo da segunda metade do século XIX, num quadro de diminuição de escravos nas propriedades ${ }^{9}$ e de crise econômica, a freqüência de famílias matrifocais aumentou. Isto foi resultado do acirramento da política senhorial contrária ao casamento, objetivando evitar qualquer tipo de interferência da Igreja. Deve ter existido escravos que também se sentiram menos estimulados a legalizar suas uniões, e cativos que encontraram dificuldades em localizar parceiros nos limites das propriedades em que viviam, diante do aumento de plantéis de pequeno porte. Conseqüentemente, os cativos se associaram a escravos de outros senhores, a forros e a livres.

Em oposição, ao longo dos anos, houve redução da participação de famílias legais, chamadas de nucleares. Elas foram mais comuns em grandes plantéis, mas também nesses, os escravos casaram menos, após $1850^{10}$.

Mesmo diante da grande incidência de famílias matrifocais, a estabilidade foi uma realidade para grande parte dos cativos aparentados, tanto na primeira quanto na segunda metade do século XIX. Os laços foram respeitados nos momentos de partilha dos bens dos inventariados, propiciando, por vezes, a formação de famílias extensas, constituídas por três ou mais gerações ${ }^{11}$.

Ao lado da consangüinidade e dos laços matrimoniais, os cativos compreenderam seus compadres e comadres como parentes. Ou seja, padrinhos e madrinhas eram entendidos como parentes rituais, que dariam amparo ou ajuda na criação dos afilhados.

Pais, filhos, padrinhos e madrinhas, eram alguns dos personagens presentes nos grupos parentais. Ao lado deles havia, ainda, avôs, tios, sobrinhos, irmãos, etc., formando famílias escravas alargadas que, por vezes, deveriam se confundir com a própria comunidade escrava.

O objetivo deste estudo é, portanto, confirmar dados já localizados por outras pesquisas, comprovar a viabilidade das idéias expostas, além de colaborar para a

\footnotetext{
${ }^{9}$ Sobre a perda de escravos nos pequenos e médios plantéis na sociedade escravista brasileira deste momento, ver Castro (1997).

${ }^{10}$ A divisão metodológica entre nucleares e matrifocais foi realizada também por Teixeira (2001).

${ }^{11}$ Acreditamos que a incidência de separações de parentes tenha sido maior nos casos de venda de escravos. Entretanto, não foi possível localizar registros de compra e venda.
} 
mudança do contexto apresentado por Faria de que "são bem poucos os trabalhos que tratam de áreas tidas como ‘insignificantes’ no quadro econômico colonial ou, mesmo, no século XIX” (FARIA, 1998, p. 57).

Visto que a análise das duas questões centrais da pesquisa — a característica das famílias e sua estabilidade — tem como pano de fundo o quadro econômico local, realizamos um mapeamento econômico, mediante observação da estrutura de posse de escravos e das produções existentes; o movimento portuário; e o grau de endividamento dos escravistas, sempre comparando os informes existentes para a primeira e a segunda metade do século.

Para avaliarmos as questões colocadas utilizamos os registros de batismo da freguesia da Ribeira, entre 1824 e 1826, da de Mambucaba, entre 1830 e 1871, e da Ilha Grande, entre 1805 e 1888; e os registros de casamento da Ribeira, entre 1827 e 1877, de Mambucaba, entre 1830 e 1871, e da Ilha Grande, entre 1851 e $1875^{12}$. Todos os registros foram localizados no Convento de Nossa Senhora do Carmo e na Igreja de Jacuecanga, ambos em Angra dos Reis.

Trabalhamos, também, com 250 inventários post-mortem, encontrados no Museu da Justiça do Estado do Rio de Janeiro, $\mathrm{RJ}^{13}$.

Organizamos, inicialmente, a massa documental paroquial e cartorária, reunindo os cativos citados em torno de seus proprietários ${ }^{14}$. Estando os escravos catalogados e distribuídos por plantéis, testamos as hipóteses, sempre comparando os dados para a primeira e a segunda metade do século $\mathrm{XIX}^{15}$.

Acerca dos principais documentos trabalhados, observamos que: os registros paroquiais desempenharam o papel de registros civis até a proclamação da república

\footnotetext{
${ }^{12}$ As informações foram anotadas por meio de fichas com os itens, no caso dos registros de batismo: data da cerimônia, nome do batizando, data de nascimento ou idade, cor, origem (crioulo ou de nação), procedência (Mina, Congo...), pais, suas origens, procedências (exclusivo no caso de crianças) e proprietários; nomes dos padrinhos e madrinhas, suas condições jurídicas (escravos, forros ou livres), origens e proprietários (quando escravos). No caso do casamento: data, cônjuges, suas origens, procedências, cor, pais (exclusivo no caso de crioulos), proprietários e testemunhas.

${ }^{13}$ Dos inventários copiamos: os nomes dos herdeiros; os bens indicados e valores; no caso do escravo, o nome, origem, procedência, idade, atividade realizada, preço e a relação de parentesco com outros cativos; os autos da partilha; os montes brutos e líquidos; e as dívidas passivas e ativas.

${ }^{14}$ Ver Apêndice.

15 Dividimos os dados em subperíodos menores para ser possível acompanharmos as mudanças. No entanto, a análise foi condicionada, principalmente, pela comparação dos informes para os anos anteriores a 1849 e posteriores a 1850 .
} 
(CASTRO, 1997) e reproduziram a hierarquia social da época mediante a separação entre livres, forros e escravos. Os registros de escravos, segundo Faria (1997) eram os que traziam menos informações, se comparados aos dois grupos sociais citados. Foram fontes que silenciaram sobre alguns itens, por exemplo, a cor e a procedência dos cativos. Já os inventários, tendo como objetivo central realizar o levantamento do patrimônio e a partilha do mesmo entre os herdeiros, reproduziu a hierarquia social da época. Esta fonte não tinha a obrigatoriedade de indicar a existência de famílias escravas, embora informasse, em geral, os laços entre pais e filhos. Não obstante, se mostrava indiferente à identificação de avós, tios e sobrinhos.

As lacunas presentes nos dois tipos de fontes foram preenchidas por meio do cruzamento das informações constantes nos documentos.

No que diz respeito às características familiares, examinamos os informes presentes no levantamento dos bens inventariados, uma vez que era comum os avaliadores citarem os laços que envolviam pais e filhos. Também analisamos os registros de casamento e de batismo.

Para a observação da segunda hipótese, o grau de estabilidade, acompanhamos a freqüência de separação, no momento da partilha, de pais sem ou com filhos e mães solteiras com filhos. Localizamos, mediante o cruzamento das fontes, se os casais sem ou com filhos e mães com filhos conviviam com demais parentes na mesma propriedade.

No que se refere às mudanças de comportamento dessas famílias diante do compadrio, a verificação se deu mediante análise dos registros de batismo.

Contudo, o estudo das mudanças econômicas e demográficas ocorridas no século XIX foram o pano de fundo para a reflexão sobre os laços familiares. Portanto, realizamos um mapeamento econômico, quando observamos os tipo de produções existentes e a avaliação da estrutura de posse de escravos. Para tal, analisamos os bens dos inventariados e os informes obtidos no Almanak Laemmert, lançado nos anos pares de 1844 até 1882, e as publicações dos anos de 1883 e 1885. Estas últimas fontes foram encontradas na Biblioteca Nacional, no Instituto Histórico e Geográfico Brasileiro (IHGB), ambas instituições localizadas no Rio de Janeiro, e na página da Universidade de Chicago <uchicago.edu/info/brazil/almanak2.htm>. 
Os demais documentos trabalhados foram os censos presentes nos relatórios dos presidentes de Província do Rio de Janeiro, para os anos de 1840, de 1850 e de 1856, encontrados na Biblioteca Nacional, e o Censo Nacional de 1872, presente no acervo do Instituto Brasileiro de Geografia e Estatística (IBGE), no Rio de Janeiro ${ }^{16}$. Em tais fontes verificamos o evolver da população e alguns dados demográficos, como origem, e, em menor escala, sexo e idades, que foram complementados pelos informes obtidos nas fontes paroquiais e cartorárias. No Jornal do Commércio, encontrado na Biblioteca Nacional, obtivemos dados relativos às embarcações saídas do litoral sul-fluminense que chegaram ao Rio de Janeiro entre 1828 e 1888 e as cargas transportadas. Com este levantamento, tivemos acesso ao movimento portuário. Estudamos os viajantes e cronistas que passaram pelo litoral sul-fluminense.

O trabalho está dividido em quatro partes. Na primeira, encontra-se três capítulos dedicados a história de Angra dos Reis, desde o século XVI, destacando-se a economia e sociedade do século XIX; as características e o evolver demográfico de livres e de escravos; um mapeamento econômico; e a estrutura de posse de escravos, entre 1800 e 1888.

Na segunda parte, formada por três capítulos, investigamos os perfis das famílias escravas e as transformações sofridas por aquela instituição parental, ao longo do século XIX; os casamentos realizados; e a questão da maternidade escrava.

Na terceira parte, organizada em quatro capítulos, estudamos os laços de compadrio, avaliando os batismos de escravos adultos, crianças escravas e ingênuas; as condições jurídicas dos padrinhos e das madrinhas; e os contatos entre os escravos de diferentes propriedades.

Na quarta parte, constituída por dois capítulos, as famílias extensas e fraternas assumem o papel principal. Além de localizar aquelas famílias, acompanhamos o destino dado às famílias nucleares, matrifocais, fraternas e extensas durante a partilha.

\footnotetext{
${ }^{16}$ Nas fontes citadas, anotamos o número de habitantes livres e de escravos nas freguesias, suas origens, e, quando possível, informações sobre sexo e faixa etária.
} 


\section{PARTE I}

\section{ECONOMIA E DEMOGRAFIA DE ANGRA DOS REIS NO SÉCULO XIX}

\section{INTRODUÇÃO}

A análise das famílias escravas em Angra dos Reis exige a compreensão da realidade na qual os cativos estavam inseridos. Por acreditar nesta tese, apresentamos a localidade que serve de recorte espacial, procurando mapeá-la do século XVI até o XIX.

A parte I divide-se em três capítulos. No primeiro, tratamos da história de Angra dos Reis, desde a chegada dos primeiros europeus até o século XIX. Damos destaque ao Oitocentos, pois corresponde ao recorte da pesquisa, priorizando os aspectos social, econômico e político. No segundo capítulo, nos detemos na evolução demográfica da população livre e escrava, em especial a cativa, observando a freqüência desta entre 1840 e 1872, a razão de sexo, a origem, a procedência, a faixa etária e a taxa de dependência ${ }^{17}$. No terceiro capítulo, por meio da análise dos inventários post-mortem, mapeamos as atividades produtivas realizadas pelos angrenses e as faixas de tamanho das escravarias.

Após a leitura dos citados capítulos, esperamos que fique perceptível o contexto no qual foram estudadas as famílias escravas: uma localidade onde seus moradores dedicavam-se à produção para o mercado interno, destacando-se a aguardente e o café. Ao mesmo tempo, os portos localizados na Baía da Ilha Grande especializaram-se, na primeira metade do século XIX, no escoamento do café proveniente do vale do Paraíba fluminense e paulista, estimulando a economia local. Na segunda parte do Oitocentos, o movimento portuário diminuiu e a obtenção de braços escravos tornou-se rarefeita. Ambos acontecimentos encorajaram a formação de um quadro de crise econômica que, conseqüentemente, influenciou a demografia local e as faixas de tamanho de propriedades.

\footnotetext{
${ }^{17}$ Origem corresponde à classificação do escravo como crioulo, nascido no Brasil, ou "de nação", nascido na África. A procedência, no caso do crioulo, representa o local de seu nascimento, por exemplo, Ilha Grande e, entre os africanos, definições como de Angola, Mina, Moçambique etc. Para uma avaliação a respeito dos possíveis significados das procedências entre os africanos, ver, por exemplo, Soares (2000) e Karasch (2000a).
} 
Nesta parte, lançamos mão das estimativas populacionais para os anos de 1840, 1850 e 1856, presentes nos relatórios de presidentes de província do Rio de Janeiro; do Censo Nacional de 1872; dos relatos de viajantes que estiveram em Angra dos Reis; dos dados relativos às embarcações que chegaram ao porto do Rio de Janeiro provenientes do litoral sul-fluminense, localizados no Jornal do Commércio, de 1827 a 1888; do Almanak Laemmert relativo aos anos pares entre 1844 e 1882 e os anos de 1883 e 1885; e dos inventários post-mortem, datados de 1800 até 1888. 


\section{CAPÍTULO 1-HISTÓRIAS DE ANGRA DOS REIS}

O litoral sul-fluminense, onde se localiza Angra dos Reis, não tem recebido muita atenção por parte dos historiadores. Isso decorre, dentre outros fatos, de que a economia local era, apenas, indiretamente vinculada à exportação, ou seja, ao mercado externo. Parati, por ser uma cidade que conseguiu conservar parte de seu centro histórico, desperta um maior interesse dos pesquisadores. Não somente por sua beleza, mas por sua intensa ligação com o escoamento do ouro no Setecentos ${ }^{18}$. Por Parati passava a produção proveniente de Minas Gerais, através do Caminho dos Guaianazes ou "Caminho Velho” do Rio de Janeiro.

Tentando contribuir para a produção do conhecimento sobre o dito litoral, apresentamos a história de Angra dos Reis. Optamos por fazer um apanhado da história local desde o século XVI pois contribuirá para a divulgação da trajetória vivida por homens e mulheres que habitaram as terras banhadas pela Baía da Ilha Grande. Nosso segundo objetivo com o capítulo é verificar as características econômicas e sociais existentes em Angra no século XIX. Desejamos com isso, demonstrar que a localidade, embora não diretamente vinculada ao mercado externo, possuía uma produção para consumo local e para o mercado interno e, o mais importante, contribuiu para o sucesso do café como principal produto de exportação. Como ocorreu em várias áreas do sudeste, os angrenses também se aventuraram como plantadores de café. No entanto, importante mesmo foi o papel desempenhado pelos portos angrenses como pólos de escoamento do café proveniente do vale do Paraíba paulista e fluminense.

A atividade portuária, por meio da navegação de cabotagem, contribuiu para períodos economicamente prósperos para Angra, na primeira metade do século XIX. Nas décadas seguintes, a construção da Estrada de Ferro D. Pedro II, responsável por desviar aquela produção dos portos angrenses, gerou uma crise econômica, só alterada na segunda década do século XX.

Ao longo do capítulo, usamos os escritos de historiadores locais; os comentários de viajantes que passaram pelo litoral sul-fluminense nos oitocentos; os dados extraídos do Almanak Laemmert relativos à província do Rio de Janeiro; e os informes constantes

${ }^{18}$ Sobre Parati citamos, entre outros, Souza (1994). 
no Jornal do Commércio, acerca das embarcações que chegaram ao Rio de Janeiro naquela centúria.

Na primeira metade do século XIX, o município de Angra dos Reis já apresentava as delimitações territoriais existentes hoje e que compõem o recorte geográfico da tese, indo do rio Caratucaia, limite com Mangaratiba, e o rio Mambucaba, fronteira com Parati.

Angra compunha-se das freguesias de Nossa Senhora da Conceição de Angra dos Reis; Nossa Senhora da Conceição da Ribeira; Nossa Senhora de Santana da Ilha Grande; Nossa Senhora do Rosário de Mambucaba; e Nossa Senhora da Santíssima Trindade de Jacuecanga.

Na freguesia de Nossa Senhora da Conceição de Angra dos Reis, atual centro da cidade, estão situados o Convento do Carmo, tendo sua construção iniciada em 1593, e o Convento de São Bernardino de Sena, de 1763 (LIMA, 1972 p. 158). No ano de 1889, sua superfície era de 50 quilômetros quadrados, com uma população de 4.800 habitantes.

Nossa Senhora da Conceição da Ribeira, criada em 1824, com superfície superior a 150 quilômetros quadrados, tinha, em 1889, 6.800 moradores (LIMA, 1972, p. 195). Localidades como Jurumirim, Itanema, Ariró, Bracuí, Frade, Cunhambebe, Ilha Comprida, entre outras, faziam parte do território da Ribeira. Cultivos de milho, feijão, café e de cana faziam parte da paisagem local.

Com mais de 193,53 quilômetros quadrados, a freguesia de Nossa Senhora de Santana da Ilha Grande, correspondendo à Ilha Grande, teve no cultivo do café uma de suas principais atividades. No ano de 1889, sua população estava em torno de 7.800 moradores (LIMA, 1972, p. 182).

A freguesia de Nossa Senhora do Rosário de Mambucaba, criada em $1808^{19}$, fazia fronteira com Parati e incluía Itaorna e Ilha de Sandre. Nela havia importante porto de onde era escoada a produção cafeeira local e do vale do Paraíba. Sua superfície de 220 quilômetros quadrados abrigava 3.800 habitantes, em 1889 (LIMA, 1972, p. 174).

Formada a partir de um desmembramento da freguesia da Conceição de Angra dos Reis, a de Nossa Senhora da Santíssima Trindade de Jacuecanga foi criada em 1856.

\footnotetext{
${ }^{19}$ Na verdade, a freguesia foi criada em 1803. Entretanto, por dificuldades encontradas para sobreviver na localidade, o vigário nomeado a abandonou em 1804. Em 1808, a freguesia foi reinstalada (cf. LIMA, 1972, p. 172-173). Todos os dados relativos às freguesias foram levantados por Lima (1972) que, no século XIX, era político e agricultor.
} 
Fronteiriça a Mangaratiba, possuía uma área de 56 quilômetros quadrados, onde viviam 4.500 habitantes, no ano de 1889 (LIMA, 1972, p. 203). 
FIGURA 1

Angra dos Reis

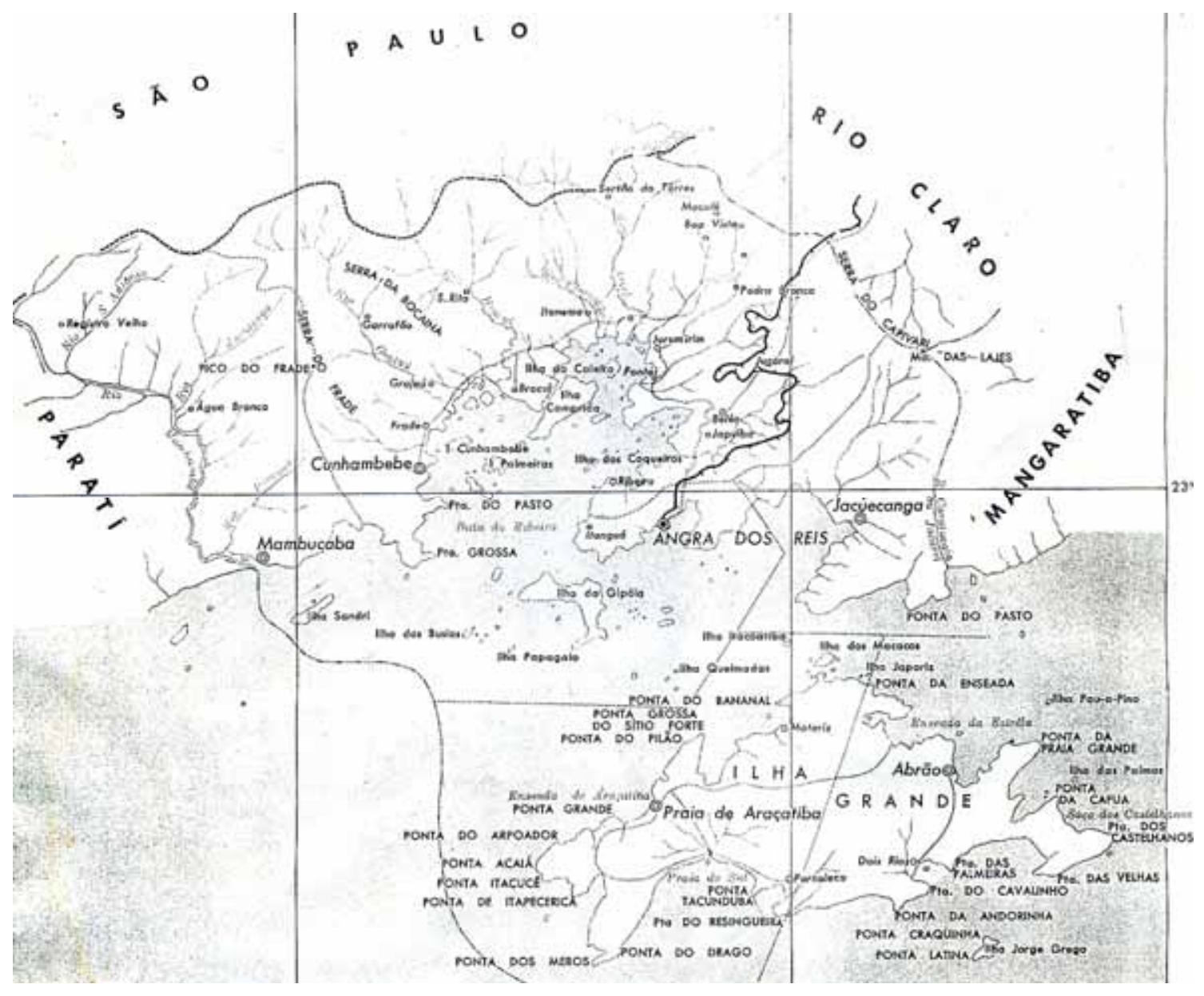

FONTE - Enciclopédia do Municípios Brasileiros 1959 - p. 199 
Feitas as apresentações iniciais, convidamos o leitor a fazer uma viagem até os idos anos do século XVI.

Angra dos Reis ${ }^{20}$ foi um dos primeiros núcleos conhecidos da Costa Sul de São Sebastião do Rio de Janeiro. Constituído por uma estreita porção de terra, cercado pela Serra do Mar e a Baía da Ilha Grande, Angra foi primeiramente visitado pelos colonizadores portugueses, em seis de janeiro, ou data próxima, de $1502 .^{21}$.

Poucos anos depois, os lusitanos encontraram aldeias indígenas tupinambás (CAPAZ, 1996, p. 28) que povoavam a Baía da Ilha Grande, gerando dificuldade para a ocupação do território por parte dos brancos, durante a primeira metade do século XVI.

Em torno de 1556, a região foi ocupada pelos filhos do Capitão-mor da Capitania de São Vicente, da qual a região fazia parte e, alguns anos depois, a Ilha Grande recebeu seus primeiros moradores europeus ${ }^{22}$. Este processo foi semelhante ao ocorrido em Parati e Ubatuba, pois "teve como primeiros habitantes brancos, pessoas vindas das vilas vicentinas, provavelmente trazidas pelos agraciados por sesmarias” (SOUZA, 1994, p. 30).

Entrementes, a fixação nem sempre foi bem sucedida e poucos portugueses renderam-se à aventura de ocupar o território. Na Ilha Grande, por exemplo, a ocupação por parte do homem branco foi lenta. Ela continuaria a ser nos séculos seguintes local de parada de corsários que buscavam terra firme para realizar reparos em suas embarcações ou reabastecê-las, mediante trocas de mercadorias com os nativos (CAPAZ, 1996, p. 119).

Em 1560, a localidade, no continente, foi elevada à condição de povoado, ocupando hoje o território conhecido como Vila Velha, em frente a Ilha da Gipóia. Em 1593, foi elevada à paróquia sob a invocação dos Santos Reis Magos, estendendo-se da margem esquerda do Rio Itaguaí à Ponta do Cairu, compreendendo, além do atual

\footnotetext{
${ }^{20}$ Até meados do século XVII, o nome que constava nos documentos oficiais era Nossa Senhora da Conceição, posteriormente Vila da Ilha Grande. A partir de 1835, com a elevação à cidade, recebeu o nome de Angra dos Reis (cf. CAPAZ, 1996, p. 21).

${ }^{21}$ André Gonçalves esteve à frente da expedição que chegou às terras que viriam a compor Angra dos Reis (MENDES, 1995, p. 7).

${ }^{22} \mathrm{O}$ ano de 1559 foi apontado como o da chegada dos primeiros moradores na Ilha Grande (cf. LIMA, 1972, p. 89).
} 
município de Angra, o maior em extensão, também os de Mangaratiba e de Parati (LIMA, 1972, p. 89).

Em fins do século XVI, uma das atividades produtivas desenvolvidas era a lavoura da cana-de-açúcar e de alimentos, além da pesca da baleia praticada na foz do rio Mambucaba (MACHADO, s.d., p. 20).

Em 1607, a povoação tornou-se vila. A mudança esteve associada, possivelmente, a sua localização estratégica, visto que estava no meio da rota marítima que ligava São Vicente a São Sebastião do Rio de Janeiro.

A sua localização poderia ter sido o motivo para a elevação, em oposição à idéia apresentada por historiadores locais que acreditaram que Angra estava vivenciando um desenvolvimento sócio-econômico (cf. LIMA, 1972; MENDES, 1970). Devemos, inclusive, tomar cuidado ao pensar numa vila em princípios do século XVII, pois:

“Chamar uma povoação de vila, por exemplo, não significava a presença de uma estrutura urbana, e sim a existência de uma pequena aglomeração, onde um número ínfimo de colonos de origem européia e seus agregados, em geral caboclos, se reuniam aos domingos para freqüentar a missa e as festas da igreja nos dias santificados” (MACHADO, s.d., p. 22).

Por volta de 1624, o povoado deslocou-se da Vila Velha, primeiro núcleo de ocupação, para o atual sítio, em frente à Ilha Grande ${ }^{23}$. Na ocasião foi iniciada a construção da Igreja Matriz de Nossa Senhora da Conceição, pronta somente em 1750. Em 1667, com a fundação da paróquia de Nossa Senhora dos Remédios de Parati, o território de Angra passou a ter como limites a faixa de terra entre o rio Itaguaí e o rio Mambucaba (LIMA, 1972, p. 153).

Durante o século XVII, o porto de Angra apresentou um modesto crescimento e um pequeno comércio era realizado com o interior, “serra acima”. Instalou-se, na segunda metade do século, um estaleiro para a construção de fragatas que seriam usadas para a navegação e policiamento marítimo, e difundiu-se a pesca da baleia.

\footnotetext{
${ }^{23} \mathrm{O}$ fato recebeu duas versões. A primeira considerou que o deslocamento foi resultado do assassinato do vigário por um morador, quando o Prelado do Rio de Janeiro suspendeu a nomeação de outro pároco, enquanto existissem, na vila, descendentes do assassino; e por isso os moradores decidiram ocupar outro local. Já a segunda versão defende que, antes do episódio, o novo sítio já vinha sendo ocupado, em função das vantagens que apresentava, como água em abundância, em contraposição aos mangues e lagoas, que incomodavam os moradores da Vila Velha (cf. CAPAZ, 1996, p. 78).
} 
O intenso contado com a Baía da Ilha Grande estimulou a pesca, atividade da qual os moradores retiravam parte de seus alimentos. A vinculação com o mar foi igualmente vista por Marcílio (1986), em relação a Ubatuba: “essa paisagem facilitou e, mesmo convidou seus moradores à vida marítima, da pesca artesanal à navegação costeira” (MARCÍlIO, 1986, p. 40).

Na virada para o século XVIII, a descoberta de ouro na região que denominou-se Minas Gerais causou uma grande modificação no ritmo de vida de toda a colônia, inicialmente visível para aquelas localidades que diretamente serviram-lhe de acesso (SOUZA, 1994, p. 32), como Parati e o resto do litoral sul-fluminense.

A partir daí, houve uma corrida de homens, estes vindos de outras partes da colônia e de “além-mar”, rumo às minas. Não obstante, a única alternativa de acesso ligando o Rio de Janeiro às minas era Parati (SOUZA, 1994, p. 33), por meio do “Caminho Velho” do Rio de Janeiro ou dos Guaianazes ${ }^{24}$.

Pelo “Caminho Velho”, ia-se do Rio de Janeiro, por mar, até Parati. De Parati seguia-se por terra até Taubaté, “onde era vencida a Serra do Facão” (SOUZA, 1994, p. 33), considerada de grande aspereza e hostil. De Taubaté, chegava-se a Pindamonhangaba, Guaratinguetá, até as roças de Garcia Rodrigues e, finalmente, ao Rio das Velhas (ANTONIL, 1982, p. 184). Segundo Antonil (1982, p. 184), o trajeto era concluído em 30 dias.

O movimento acabou dinamizando Parati. “A vila tinha crescido, cultivou-se mais a terra, aumentou o movimento do porto, do comércio, do transporte de mercadorias e escravos” (SOUZA, 1994, p. 37). A agitação que se abateu sobre a comunidade paratiense, também beneficiou a vila de Angra, para onde foram os “descaminhos" do ouro.

“A partir de Angra dos Reis, desde o início do século XVIII, subiam exploradores da Serra do Mar, provavelmente buscando alternativas para a saída do ouro proveniente das Minas. Podemos supor, assim, que por essa época o contrabando permitiu o sustento de muitas famílias e povoações angrenses” (MACHADO, s.d., p. 23).

\footnotetext{
${ }^{24}$ Embora o caminho tenha recebido grande contingente humano, ele já vinha sendo freqüentado por paulistas e paratienses, visando a realização de um pequeno comércio de trocas de produtos agrícolas de ambas localidades (cf. GURGEL \& AMARAL, 1973, p. 41).
} 
Por intermédio da correspondência de governadores do Rio de Janeiro, entre 1685 e 1733, Capaz (1996) localizou mais de quarenta entradas de barcos franceses, ingleses e holandeses na Baía da Ilha Grande. Muitos descarregavam contrabandos destinados ao Rio de Janeiro, São Paulo e Minas Gerais ${ }^{25}$.

Em virtude do constante risco de contrabando, principalmente realizado no percurso marítimo do “Caminho Velho”, da aspereza e da longa duração da viagem, o governo metropolitano incentivou a abertura de outro percurso que fosse somente terrestre entre o Rio de Janeiro e Minas Gerais (SOUZA, 1994, p. 33). "De fato, a Coroa passou a estimular a abertura de novos caminhos, oferecendo sesmarias, títulos e outros privilégios aos particulares que quisessem bancar a construção” (MACHADO, s.d., p. 23).

Foi construído o "Caminho Novo" ou de Garcia Rodrigues Paes (MACHADO, s.d., p. 23). Sobre ele, sabemos que as obras foram iniciadas ainda em 1698. Três anos depois, em 1701, dava passagem somente a pedestres (SOUZA, 1994, p. 33-34). Nos seis anos seguintes, Garcia Rodrigues Paes se dedicou à melhoria da estrada; enquanto Bernardo Soares de Proença realizou reparos, garantindo a diminuição do tempo de viagem, chegando, finalmente, a doze dias (SOUZA, 1994, p. 34).

O trajeto diminuiu o trânsito existente no porto de Parati e, indiretamente, no de Angra. Na segunda metade do século XVIII, os paratienses começaram a sentir a queda dos negócios: a venda de alimentos e a hospedagem aos que iam e aos que vinham de Minas. A abertura do "Caminho Novo" desviou grande parte do movimento comercial de Parati, porém, segundo Souza (1994, p. 38), a vila continuou articulada à efervescência mineira, através do vale do Paraíba - área cada vez mais povoada e produtiva, importante pólo de abastecimento das Minas. Ainda segundo a autora, "embora de importância secundária, o porto de Parati estava inserido na florescente economia da região” (SOUZA, 1994, p. 38). Os paratienses dedicavam-se também à agricultura de gêneros alimentícios e à produção da aguardente que, em pouco, se tornou uma das mais conhecidas (GURGEL \& AMARAL, 1973, p. 47-48).

\footnotetext{
${ }^{25}$ A atividade se intensificou com a mineração (cf. CAPAZ, 1996, p. 119).
} 
Diante da redução do fluxo pelo "Caminho Velho", foram abertos "caminhos" paralelos, ligando as Gerais aos portos do litoral sul-fluminense, que serviram para o contrabando do ouro. Este tornou-se prática tão habitual na região que foi criado um "sistema” de "apoio" aos contrabandistas, voltado para a comercialização de alimentos, "um sistema de suporte aos bucaneiros de além-mar, com a intensificação de contrabando e da venda irregular de mantimentos aos estrangeiros” (CAPAZ, 1996, p. 99). Esta prática ocorreu, igualmente, em diversos pontos do litoral brasileiro, por exemplo, o litoral norte paulista (FERNÁNDEZ, 1992, p. 53).

Na segunda metade do século XVIII, contribuíram para que a lavoura canavieira se espalhasse do Recôncavo da Guanabara para as planícies de Campos e Cabo Frio: a transferência da sede do vice-reinado para o Rio de Janeiro, o desenvolvimento do porto carioca, baseado em manufaturados, escravos e ouro, e o estímulo dado pela metrópole visando a intensificação da produção agrícola colonial, incluindo, além do açúcar, fumo, anil, café etc. (SOUZA, 1994, p. 38).

Para Angra, as mudanças ofereceram novas possibilidades de atividades econômicas, amenizando reflexos à economia local decorrentes da crise da mineração (MACHADO, s.d., p. 24). No final do século, o movimento portuário dinamizou-se, antigas atividades se ampliaram e novas surgiram ${ }^{26}$.

O cultivo de anil disseminou-se, principalmente entre as grandes propriedades ${ }^{27}$. Expandiram-se a lavoura de alimentos e a atividade pesqueira. No entanto, a produção com maior revitalização foi a aguardente, absorvendo o cultivo da cana-de-açúcar de Angra e de Parati.

Dados apresentados por Fragoso (1992) confirmaram a importância assumida pela aguardente. Segundo ele, entre os anos de 1769 e 1778, houve um crescimento no número de engenhos na Capitania do Rio de Janeiro, passando de 202 para 339 e uma pequena

\footnotetext{
${ }^{26}$ Em 1764, com a fundação da paróquia de Nossa Senhora da Guia de Mangaratiba, a paróquia de Angra diminuiu de extensão (cf. LIMA, 1972, p. 153).

${ }^{27}$ Sua importância foi tanta que uma das praias do atual centro de Angra recebeu seu nome, a Praia do Anil. O cultivo perdeu importância em princípios do século XIX (cf. MACHADO, s.d., p. 25).
} 
redução no número de engenhocas, de 183 para $181^{28}$. Durante aqueles anos, na vila de Angra, o número de engenhos passou de três a 10, e na vila de Parati, de zero a cinco.

Em 1778, o litoral sul-fluminense concentrava 3,5\% dos engenhos existentes na Capitania, enquanto 49,5\% estavam em Campos e 2,4\%, em Cabo Frio. No que se refere às engenhocas, o maior número encontrava-se no litoral sul-fluminense, sendo que Angra possuía 82 e Parati, 67 (FRAGOSO, 1992, p. 81). Em 1794, Angra dos Reis já contava com 14 engenhos e 91 engenhocas (ARAÚJO, 1945, p. 67). No ano de 1799, dos 616 engenhos localizados na Capitania, 324 (52,0\%) estavam ao redor de Campos, no litoral sul-fluminense havia 39 (6,3\%), 25 (2,1\%) em Cabo Frio e 228 (37,0\%) nos contornos da Guanabara. Das 253 engenhocas, Campos possuía quatro (1,6\%), Cabo Frio, nove (3,6\%), contornos da Guanabara, 85 (33,6\%) e o litoral sul, 155 (61,3\%) (MARCONDES, 1995, p. 247-248).

O norte fluminense, em particular Campos, se definiu como importante produtor de açúcar; enquanto, a aguardente foi fabricada, principalmente, no sul.

Araújo (1945, p. 79-80), em visita a Angra dos Reis, em fins do século XVIII, observou que:

“apesar de não ser das melhores a situação da vila, por circulada de morros a curta várzea, em que se levantou, fronteira à Ilha Grande (da qual tomou o nome a terra firme); é contudo acomodada à vivenda, por gozar de clima temperado, ar sadio, e abundante água e ser mui apta para o negócio mercantil, distando alguns palmos da foz do mar, onde se acha seguro ancoradouro para vasos de transportes”.

Segundo Araújo, havia um movimento comercial na vila, envolvendo cultivos da localidade, e "mais de quinze lanchas armadas a sumaca” (ARAUJO, 1945, p. 85), em 1800. Verificou, além da produção da aguardente, cultivos de arroz, café, anil, cacau, algodão, legumes, laranja, banana e mandioca para fabricação da farinha (ARAUJO, 1945, p. 68).

\footnotetext{
${ }^{28}$ Engenho refere-se a estabelecimento agrícola destinado à cultura da cana e à fabricação do açúcar; enquanto engenhoca corresponde a estabelecimento mais modesto e voltado, principalmente, à fabricação da aguardente (cf. ANTONIL, 1982, p. 212).
} 
Em fins do século XVIII, com a expansão cafeeira ${ }^{29}$, o pólo dinâmico da atividade econômica deslocou-se de Parati para Angra. Isso se deu em virtude não só das vantagens do porto localizado na vila de Angra, mais profundo e livre de assoreamento; mas também, pela existência de pequenos embarcadouros naturais, caso de Jurumirim, Bracuí, Ariró, Frade e Mambucaba, fixados na Baía da Ilha Grande, próximos às produtoras de café "serra acima” (CAPAZ, 1996, p. 100-101).

O litoral sul-fluminense especializou-se no escoamento da produção proveniente do vale do Paraíba. Isso ocorreu em função da abertura ou melhoria das estradas.

"A abertura ou melhoria das vias de comunicação no vale do Paraíba fluminense e paulista deve ter ocorrido entre fins do século dezoito e a primeira metade do dezenove, adicionalmente, como portas de saída para os cafés da mencionada região, desenvolveu-se os portos localizados no golfo angrense” (MOTTA, 1999a, p. 51).

Foram recuperados caminhos antigos e novos foram abertos:

“Pelo vale do Ariró, além da 'estrada de barro', à margem da qual surgiu, na primeira metade do século XIX, Santo Antônio do Capivari (hoje Lídice), no caminho em direção a São João Marcos, passavam as estradas do Caramujo (em direção a Bananal), e a 'estrada João de Oliveira', que desembocava na foz do Jurumirim. Pelo vale do Bracuí, outro caminho subia a serra em direção a Bananal. E pelo vale do Mambucaba atravessava a Serra da Bocaina em direção a Areias” (MACHADO, s.d., p. 26).

Em Angra chegavam tropas de São João Marcos, de Resende, de Piraí, de São Paulo e de Minas Gerais (cf. LAMEGO, 1964, p. 241). O porto, neste contexto, tornou-se de grande importância, "é o seu porto o mais próximo e o melhor dos surgidouros para a exportação” (LAMEGO, 1964, p. 241). Além desse, surgiram outros embarcadouros como os de Jurumirim, Ariró, Ribeira, Mambucaba, Bracuí e Frade (LAMEGO, 1964, p. 242).

Por meio da tabela 1 podemos verificar o movimento portuário local.

${ }^{29}$ A expansão do café iniciou-se na cidade do Rio de Janeiro. Posteriormente, o cultivo foi para Resende e São João Marcos, sendo que, entre 1830 e 1860, a região ocidental do vale do Paraíba foi detentora da produção cafeeira, incluindo, além de Resende, também Barra Mansa, Piraí, Vassouras, São João Marcos, Passa Três e Santa Ana (cf. MARCONDES, 1995, p. 252). 


\section{TABELA 1}

Saída de barcos do litoral sul-fluminense em direção ao Rio de Janeiro, 1827-1888

\begin{tabular}{|c|c|c|c|c|}
\hline Subperíodos & Localidades & Barcos & $\%$ & Média mensal \\
\hline \multirow[t]{4}{*}{ 1827-1829 } & Mangaratiba & 77 & 31,8 & 7,7 \\
\hline & Angra & 115 & 47,5 & 11,5 \\
\hline & Parati & 50 & 20,7 & 5,0 \\
\hline & St & 242 & 100,0 & 24,2 \\
\hline \multirow[t]{4}{*}{$1830-1839$} & Mangaratiba & 453 & 36,9 & 11,3 \\
\hline & Angra & 607 & 49,4 & 15,2 \\
\hline & Parati & 169 & 13,7 & 4,2 \\
\hline & St & 1.229 & 100,0 & 30,7 \\
\hline \multirow[t]{4}{*}{$1840-1849$} & Mangaratiba & 461 & 31,8 & 11,5 \\
\hline & Angra & 736 & 50,8 & 18,4 \\
\hline & Parati & 253 & 17,4 & 6,3 \\
\hline & St & 1.450 & 100,0 & 36,2 \\
\hline \multirow[t]{4}{*}{ 1850-1859 } & Mangaratiba & 439 & 27,9 & 10,9 \\
\hline & Angra & 900 & 57,3 & 22,5 \\
\hline & Parati & 232 & 14,8 & 5,8 \\
\hline & St & 1.571 & 100,0 & 39,3 \\
\hline \multirow[t]{4}{*}{ 1860-1869 } & Mangaratiba & 271 & 24,0 & 6,7 \\
\hline & Angra & 506 & 44,8 & 12,6 \\
\hline & Parati & 352 & 31,2 & 8,8 \\
\hline & St & 1.129 & 100,0 & 28,2 \\
\hline \multirow[t]{4}{*}{$1870-1879$} & Mangaratiba & 117 & 20,7 & 2,9 \\
\hline & Angra & 182 & 32,2 & 4,5 \\
\hline & Parati & 267 & 47,1 & 6,6 \\
\hline & St & 566 & 100,0 & 14,1 \\
\hline \multirow[t]{4}{*}{$1880-1888$} & Mangaratiba & 55 & 15,7 & 1,5 \\
\hline & Angra & 183 & 52,1 & 5,1 \\
\hline & Parati & 113 & 32,2 & 3,1 \\
\hline & St & 351 & 100,0 & 9,7 \\
\hline \multirow[t]{4}{*}{$1827-1888$} & Mangaratiba & 1.873 & 28,6 & 7,6 \\
\hline & Angra & 3.229 & 49,4 & 13,1 \\
\hline & Parati & 1.436 & 22,0 & 5,8 \\
\hline & Total & 6.538 & 100,0 & 26,6 \\
\hline
\end{tabular}

FONTE: Jornal do Commércio, meses de março, setembro, outubro e novembro, 1827-1888. Biblioteca Nacional, Rio de Janeiro, RJ.

NOTA: St=subtotal. 


\section{TABELA 2}

Cargas transportadas pelos barcos saídos do litoral sul-fluminense em direção ao Rio de Janeiro, 1827-1888

\begin{tabular}{|c|c|c|c|c|c|c|c|c|}
\hline Subperíodos & Localidades & $\begin{array}{c}\text { Café } \\
\mathrm{n}^{\circ}(\%)\end{array}$ & $\begin{array}{l}\text { Fumo } \\
\mathrm{n}^{\circ}(\%)\end{array}$ & \begin{tabular}{|c} 
Aguardente \\
$\mathrm{n}^{\circ}(\%)$
\end{tabular} & $\begin{array}{c}\text { Mantimento } \\
\mathrm{n}^{\circ}(\%)\end{array}$ & $\begin{array}{c}\text { Gêneros } \\
n^{\circ}(\%)\end{array}$ & $\begin{array}{l}\text { Outros } \\
n^{\circ}(\%)\end{array}$ & $\begin{array}{c}\text { Total } \\
\mathrm{n}^{\circ}(\%) \\
\end{array}$ \\
\hline \multirow[t]{4}{*}{$1827-1829$} & Mangaratiba & $51(49,0)$ & 0 & $9(8,6)$ & $30(28,9)$ & $11(10,6)$ & $3(2,9)$ & $104(100,0)$ \\
\hline & Angra & $76(55,1)$ & $5(3,6)$ & $46(33,3)$ & $5(3,6)$ & $6(4,4)$ & 0 & $138(100,0)$ \\
\hline & Parati & $37(42,0)$ & $18(20,5)$ & $28(31,8)$ & $3(3,4)$ & $2(2,3)$ & 0 & $88(100,0)$ \\
\hline & St 1 & $164(49,7)$ & $23(7,0)$ & $83(25,1)$ & $38(11,5)$ & $19(5,8)$ & $3(0,9)$ & $330(100,0)$ \\
\hline \multirow[t]{4}{*}{$1830-1839$} & Mangaratiba & $378(82,7)$ & $7(1,5)$ & $8(1,8)$ & $14(3,1)$ & $49(10,7)$ & $1(0,2)$ & $457(100,0)$ \\
\hline & Angra & $506(78,1)$ & $19(2,9)$ & $51(7,9)$ & 11( & $42(6,5)$ & $19(2,9)$ & $648(100,0)$ \\
\hline & Parati & $130(40,1)$ & $63(19,5)$ & $77(23,8)$ & $38(11,7)$ & $13(4,0)$ & $3(0,9)$ & $324(100,0)$ \\
\hline & St 2 & $1.014(71,0)$ & $89(6,2)$ & $136(9,5)$ & 63 & 104 & $23(1,6)$ & $1.429(100,0)$ \\
\hline \multirow[t]{4}{*}{$1840-1849$} & Mangaratiba & $451(97,8)$ & $1(0,2)$ & $2(0,4)$ & $2(0$ & $3(0,7)$ & $2(0,4)$ & $461(100,0)$ \\
\hline & Angra & $714(96,9)$ & $3(0,4)$ & ,5) & 5 & 10 & $1(0,1)$ & $737(100,0)$ \\
\hline & Parati & $214(47,2)$ & $123(27,2)$ & $47(10,4)$ & 7 & 53 & $9(2,0)$ & $43(100,0)$ \\
\hline & St 3 & $1.379(83,5)$ & $127(7,7)$ & $53(3,2)$ & 14 & 66 & $12(0,7)$ & $1.651(100,0)$ \\
\hline \multirow[t]{4}{*}{$1850-1859$} & Mangaratiba & $410(98,3)$ & $3(0,7)$ & 0 & 1 & $1(0,2)$ & $2(0,5)$ & 417 \\
\hline & Angra & 874 & $58(6,1)$ & 3( & & 12 & $7(0,7)$ & 955 \\
\hline & Parati & 202 & 143 & & & 55 & $3(0,7)$ & $00,0)$ \\
\hline & St 4 & $1.486(81,8)$ & $204(11,2)$ & 42( & 4 & 68 & $12(0,7)$ & $1.816(100,0)$ \\
\hline \multirow[t]{4}{*}{$1860-1869$} & Mangaratiba & $260(85,2)$ & $10(3$ & 21 & $1(0$ & 11 & $2(0,7)$ & $305(100,0)$ \\
\hline & Angra & $424(81,2)$ & $7(1,3)$ & $60(11,5)$ & 0 & $14(2,7)$ & $17(3,3)$ & $522(100,0)$ \\
\hline & Parati & $258(42,6)$ & $133(21,9)$ & $83(13,7)$ & $6(1,0)$ & $111(18,3)$ & $15(2,5)$ & $606(100,0)$ \\
\hline & St 5 & $942(65,7)$ & $150(10,5)$ & $164(11,4)$ & $7(0,5)$ & $136(9,5)$ & $34(2,4)$ & $1.433(100,0)$ \\
\hline \multirow[t]{4}{*}{$1870-1879$} & Mangaratiba & $68(55,3)$ & $8(6,5)$ & $13(10,6)$ & 31 & 19( & $12(9,8)$ & 123 \\
\hline & Angra & $133(47,5)$ & $1(0,3)$ & $104(37,1)$ & $19(6,8)$ & $9(3,2)$ & $14(5,0)$ & $280(100,0)$ \\
\hline & Parati & $54(18,4)$ & $32(10,9)$ & $65(22,2)$ & $6(2,0)$ & $117(39,9)$ & $19(6,5)$ & $293(100,0)$ \\
\hline & St 6 & $255(36,6)$ & $41(5,9)$ & $182(26,2)$ & $28(4,0)$ & $145(20,8)$ & $45(6,5)$ & $696(100,0)$ \\
\hline \multirow[t]{4}{*}{ 1880-1888 } & Mangaratiba & $7(77,8)$ & 0 & 0 & 0 & $2(22,2)$ & 0 & $9(100,0)$ \\
\hline & Angra & $55(42,3)$ & 0 & $60(46,1)$ & $1(0,8)$ & $8(6,1)$ & $6(4,6)$ & $130(100,0)$ \\
\hline & Parati & $18(12,0)$ & 0 & $52(34,6)$ & $1(0,7)$ & $69(46,0)$ & $10(6,7)$ & $150(100,0)$ \\
\hline & St 7 & $80(27,7)$ & 0 & $112(38,8)$ & $2(0,7)$ & $79(27,3)$ & $16(5,5)$ & $289(100,0)$ \\
\hline \multirow[t]{4}{*}{$1827-1888$} & Mangaratiba & $1.625(86,6)$ & $29(1,5)$ & $53(2,8)$ & $51(2,7)$ & $96(5,1)$ & $22(1,2)$ & $1.876(100,0)$ \\
\hline & Angra & $2.782(81,6)$ & $93(2,7)$ & $328(9,6)$ & $42(1,2)$ & $101(3,0)$ & $64(1,9)$ & $3.410(100,0)$ \\
\hline & Parati & $913(38,7)$ & $512(21,7)$ & $391(16,6)$ & $63(2,7)$ & $420(17,8)$ & $59(2,5)$ & $2.358(100,0)$ \\
\hline & Total & $5.320(69,6)$ & $634(8,3)$ & $772(10,1)$ & $156(2,0)$ & $617(8,1)$ & $145(1,9)$ & $7.644(100,0)$ \\
\hline
\end{tabular}

FONTE: Jornal do Commércio, meses de março, setembro, outubro e novembro, 1827-1888. Biblioteca Nacional, Rio de Janeiro, RJ.

NOTAS: St=subtotal; Entre os mantimentos foram incluídos, além das cargas assim definidas, arroz, feijão, carne, maçã, milho, farinha, peixe, toucinho e açúcar; entre os gêneros, computamos também louro, algodão, azeite, vinho e banha; e, no caso dos outros, cargas como cal, madeira, lenha, papel, papelão, cobre, vidro, carvão, couro, areia, taboa, garrafa e etc. 
As tabelas 1 e 2 serviram de dados relativos às embarcações que chegaram ao Rio de Janeiro, segundo o Jornal do Commércio dos anos de 1827 até $1888^{30}$.

Sobre a tabela 1, vale a observação de que houve embarcações, principalmente a partir de 1870, que haviam trafegado por mais de uma localidade, como o Vapor Pirahy, que transportava café e milho, e que passou por Angra e Mangaratiba ${ }^{31}$. Nesta situação, optamos por anotar o barco como procedente das duas regiões ${ }^{32}$. No caso da tabela 2, as cargas foram computadas uma única vez, pois o intento era as entradas no Rio de Janeiro.

Feitos os comentários, voltemos à tabela 1. Entre 1827 e 1888, 6.538 barcos saíram dos portos do litoral sul-fluminense.

Antes mesmo do século XIX, o movimento portuário no litoral já era intenso. Segundo notícias de 1791, aportaram 69 (13,9\%) embarcações provenientes de Angra dos Reis, com carregamentos de cachaça, mel, açúcar e feijão; enquanto que, de Parati, foram $86(17,4 \%)$ barcos, contendo toucinho, cachaça e tabaco. De ambas localidades chegaram 155 (31,3\%) embarcações, de um total de 495 que alcançaram o porto carioca (FRAGOSO, 1992, p. 87).

Nos anos de 1827 até 1888, das 6.538 saídas, grande parte dos barcos chegou ao Rio de Janeiro com carregamento de café, correspondendo a $5.320(69,6 \%)$ embarcações. A aguardente foi transportada por 772 (10,1\%) e 634 (8,3\%) naus trouxeram fumo.

Dos portos do litoral, entre 1827 e 1888, destacaram-se os de Angra, local por onde passaram 3.229 embarcações, com uma média mensal de 13,1 barcos saídos daquele município. De Mangaratiba vieram 1.873 barcos e 1.436, de Parati. Em média, foram, respectivamente, 7,6 e 5,8 sumacas, lanchas, etc. que embarcaram dos portos mangaratibano e paratiense.

\footnotetext{
${ }^{30}$ Os informes recolhidos foram relativos aos meses de março, setembro, outubro e novembro, excetuando o ano de 1827, ano de criação do jornal, que se referiu as informações dos meses de outubro e novembro. Como o objetivo era chegar a uma breve estimativa da cabotagem no litoral, não consideramos necessário recolher os dados de todos os meses, mas selecioná-los, aleatoriamente, quatro meses que viessem a servir de base para a análise.

${ }^{31}$ A embarcação foi citada no jornal do dia 20 de março de 1877.

${ }^{32}$ O número de barcos citado na tabela 1 não corresponde ao número de embarcações que chegaram ao Rio de Janeiro, mas, sim, às vezes que as embarcações passaram pelos portos do litoral. Por exemplo, o Vapor Pirahy foi contado duas vezes, tanto por ter passado por Angra quanto por Mangaratiba.
} 
O movimento foi apontado por Luccock (1975), quando analisou o comércio de cabotagem do sul para o Rio de Janeiro, em princípios do século XIX. Faziam parte da rota, os distritos da Ilha Grande, Santos, Santa Catarina e Rio Grande (LUCCOCK, 1975, p. 388), sendo que o porto da Ilha Grande, leia-se Angra dos Reis, foi considerado importante. Na localidade havia o predomínio de marinheiros que moravam nos arredores, e que também ocupavam-se da lavoura. Concomitantemente, entravam pelos portos do litoral sul-fluminense, artigos de primeira necessidade e de luxo (LUCCOCK, 1975, p. 402).

Entre 1828 e 1888, dos portos angrenses, grande parte das embarcações trouxeram café ao Rio de Janeiro, correspondendo a 2.782 (81, 6\%).

O café provinha de plantações locais, vistas por viajantes que passaram pela localidade. Segundo Pohl (1976, p. 69), que esteve no Brasil entre 1817 e 1821, os cafezais faziam parte da paisagem, além de cana-de-açúcar, bananeiras e laranjeiras. Já o viajante Kidder (1980) observou, em 1839, após a elevação da vila de Angra à categoria de cidade (CAPAZ, 1996, p. 175), plantações de café e de cana-de-açúcar nas terras da freguesia da Ilha Grande. (KIDDER, 1980, p. 183).

Dados extraídos do Almanak Laemmert indicaram a existência de fazendeiros e lavradores de café, somando, por exemplo, 114, em 1862, enquanto, em 1854, 10 eram definidos como fazendeiros de café e aguardente e 79 se dedicavam ao cultivo de café e mantimentos. Segundo este mesmo almanaque no ano de 1854, o café transportado provinha de Angra, mas também da "serra acima": "navegam por este município cinco vapores e vários barcos que carregam café da província de São Paulo e deste município, sendo o do município acima de 250.000 arrobas”33.

Angra recebia a produção do vale do Paraíba fluminense, de regiões como Barra Mansa, Rio Claro e Capivari ${ }^{34}$. Do vale paulista, vinham sacas de café provenientes de plantações de Bananal, Areias e Cunha.

O escoamento foi garantido por estradas e por armazéns de café, instalados ao longo do litoral. Sobre eles, o dito periódico, de 1848, citou a presença de 21 armazéns, além de negociantes de café, correspondendo a 15, no ano de 1856.

\footnotetext{
${ }^{33}$ A informação foi retirada do Almanak Laemmert do ano de 1854, p. 23.

${ }^{34}$ Atual distrito de Lídice, pertencente ao Município de Rio Claro, estado do Rio de Janeiro.
} 
O mesmo tipo de carregamento foi transportado por grande parte dos barcos que passaram por Mangaratiba. Das 1.873 (28,6\%) saídas, entre 1827 e 1888 (cf. tabela 1), a rubiácea foi indicada por 1.625 (86,6\%) mestres de embarcações.

O café transportado provinha da produção local, mas, também, de São João Marcos, São Joaquim e Arrozal.

De Parati saíram 1.436 (22,0\%) das 6.538 embarcações que chegaram ao Rio de Janeiro, segundo a tabela 1. Foram 913 (38,7\%) barcos que carregaram café, fruto de plantações locais, e de regiões como Cunha. Do porto paratiense saía uma diversidade de produtos, por exemplo o fumo, compreendendo a carga de $512(21,7 \%)$ barcos. Ele era produzido pelos paratienses e também pelos mineiros. Cargas definidas como gêneros, 420 (17,8\%), e aguardente, 391 (16,6\%), também se destacaram. A bebida, realizada no município desde o século XVIII, era fabricada, com freqüência em 1817 (SPIX \& MARTIUS, 1981, p. 72).

Enfim, em parte do século XIX, a população de todo o litoral e, em particular, da região em estudo, estava voltada para o cultivo de café e de alimentos. O movimento de seus portos, por sua vez, estimulou a economia, por meio da venda de excedentes aos homens que subiam e desciam a serra.

A atividade portuária existente em Angra foi comum as demais localidades, como o litoral norte paulista. Dentre elas, Ubatuba se destacou. Além de ter sido importante produtora de café, escoava, em maior volume, “a produção das terras de seu hinterland serra acima” (FERNÁNDEZ, 1992, p. 65).

Por último, é interessante citar o estudo de Marcondes (1995) sobre a dinâmica demográfica do Rio de Janeiro, entre 1780 e 1840. Para a análise, o autor dividiu a capitania, posteriormente província do Rio de Janeiro, em áreas, tendo como critério o tipo de cultivo predominante nas suas diversas partes. Da comparação surgiram quatro grandes grupos: o chamado "Rio”, que correspondia a Corte; “açúcar”, envolvendo localidades onde a cana era o principal cultivo; “café”, que incluía aquelas cuja atividade predominante era a cafeicultura; e, finalmente, “outros”, compreendendo regiões onde o café e o açúcar não eram predominantes, embora existentes e dividindo a atenção de seus moradores com a produção da aguardente, e também das atividades de transporte e de comércio. Segundo o pesquisador, o litoral sul-fluminense foi incluído na área definida 
como “outros”, ao lado da baixada fluminense, Macacu e Magé (MARCONDES, 1995, p. 246).

Na próxima página, o mapa elaborado por Marcondes (1995). 
FIGURA 2

Caracterização econômica do ômica do Rio de Janeiro, 1780-1840.

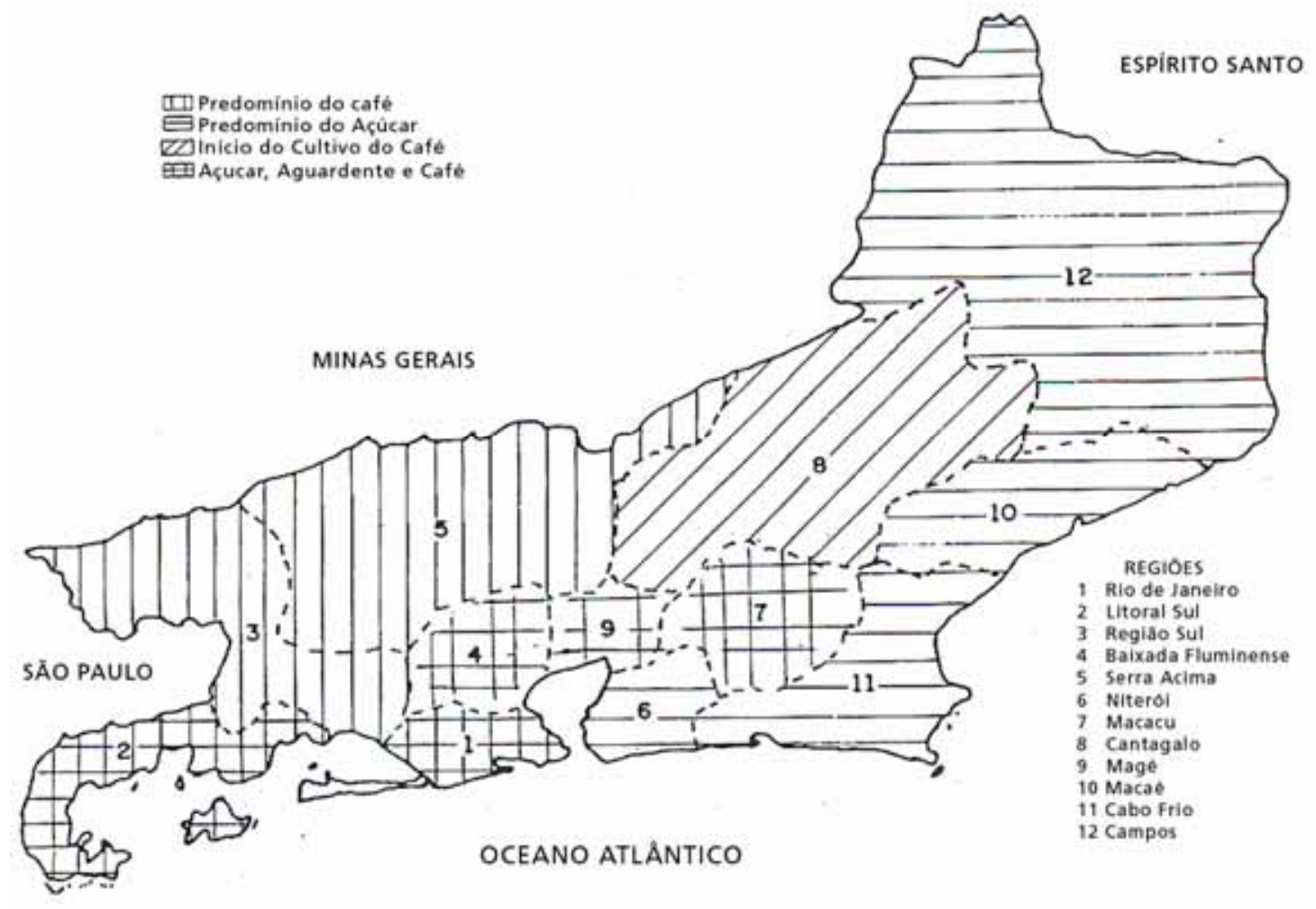

FONTE - Marcondes (1995, p. 246) 
Segundo ele, o grupo “outros” é o

"mais heterogêneo e com respeito ao qual não conseguimos determinar o predomínio de uma cultura como nas demais áreas em função de todas apresentarem alguma produção de açúcar e mesmo café, com maior ou menor intensidade. Nelas, as demais atividades também desempenhavam papel importante, como o transporte, o comércio e a produção de bens de subsistência” (MARCONDES, 1995, p. 253).

Consideramos a caracterização feita por Marcondes (1995) uma boa definição de Angra dos Reis, podendo oferecer ao leitor uma noção acerca das atividades existentes na região em observação.

Portanto, os gêneros alimentícios cultivados nas terras angrenses eram consumidos pelos próprios agricultores e vendidos para os armazéns locais. O café e a aguardente além de serem consumidos pela população, também eram comercializados no Rio de Janeiro. Além da pesca, atividade que complementava a dieta alimentar, os habitantes contavam com a atividade de transporte do café.

No entanto, o movimento portuário variou ao longo dos oitocentos. Houve um movimento ascendente até 1859, quando, em média, 39,3 embarcações saíam, por mês, do litoral sul-fluminense em direção ao porto carioca e, em seguida, um decréscimo pois, entre 1880 e 1888, 9,7 barcos deixaram os portos do dito litoral.

Percebemos que a partir de 1860 houve uma diminuição da atividade portuária no litoral e uma mudança, no tipo predominante de nau e de sua capacidade de transporte de cargas. 
TABELA 3

Tipos de embarcações provenientes do litoral sul-fluminense rumo ao Rio de Janeiro, 1827-1888

\begin{tabular}{cccccccccc}
\hline Embarcações & $\begin{array}{c}1827-1829 \\
\mathrm{n}^{\circ}(\%)\end{array}$ & $\begin{array}{c}1827-1829 \\
\mathrm{n}^{\circ}(\%)\end{array}$ & $\begin{array}{c}1827-1829 \\
\mathrm{n}^{\circ}(\%)\end{array}$ & $\begin{array}{c}1827-1829 \\
\mathrm{n}^{\circ}(\%)\end{array}$ & $\begin{array}{c}1827-1829 \\
\mathrm{n}^{\circ}(\%)\end{array}$ & $\begin{array}{c}1827-1829 \\
\mathrm{n}^{\circ}(\%)\end{array}$ & $\begin{array}{c}1827-1829 \\
\mathrm{n}^{\circ}(\%)\end{array}$ \\
\hline Barca & 0 & 0 & 0 & $1(0,1)$ & $1(0,1)$ & 0 & 0 \\
Barco & 0 & $1(0,1)$ & $1(0,1)$ & 0 & 0 & 0 & 0 \\
Bergantim & 0 & $1(0,1)$ & 0 & 0 & 0 & 0 & 0 \\
Brigue & 0 & $1(0,1)$ & 0 & $26(1,6)$ & 0 & 0 & 0 \\
Brigue escuna & $1(0,4)$ & $2(0,2)$ & $212(14,6)$ & $163(10,4)$ & $27(2,4)$ & 0 & $1(0,3)$ \\
Canhoeira & 0 & 0 & 0 & $1(0,1)$ & 0 & 0 & $3(0,9)$ \\
Canoa & $24(9,9)$ & $2(0,2)$ & 0 & 0 & 0 & 0 & 0 \\
Corveta & 0 & 0 & 0 & 0 & 0 & 0 & $6(1,7)$ \\
Cruzador & 0 & 0 & 0 & 0 & 0 & 0 & $1(0,3)$ \\
Cuter de guerra & 0 & 0 & $1(0,1)$ & 0 & 0 & $1(0,2)$ & 0 \\
Escuna & $2(0,8)$ & $97(7,9)$ & $14(0,9)$ & $13(0,8)$ & $29(2,6)$ & $22(3,9)$ & $2(0,6)$ \\
Fragata & $1(0,4)$ & 0 & 0 & $1(0,1)$ & $3(0,3)$ & $1(0,2)$ & $1(0,3)$ \\
Iate & 0 & $54(4,4)$ & $42(2,9)$ & $13(0,8)$ & $33(2,9)$ & $39(6,8)$ & $23(6,5)$ \\
Ilegível & $1(0,4)$ & $3(0,2)$ & $2(0,2)$ & $5(0,3)$ & $2(0,2)$ & $1(0,2)$ & 0 \\
Lancha & $208(86,0)$ & $104(8,5)$ & $6(0,4)$ & $1(0,1)$ & 0 & 0 & $1(0,3)$ \\
Monitor & $1(0,4)$ & 0 & 0 & 0 & 0 & 0 & 0 \\
Paquete & 0 & $8(0,6)$ & $1(0,1)$ & 0 & 0 & 0 & $6(1,7)$ \\
Patacho & 0 & $15(1,2)$ & $98(6,7)$ & $317(20,2)$ & $280(24,8)$ & $68(12,0)$ & $65(18,5)$ \\
Rebocador & $2(0,8)$ & 0 & 0 & 0 & 0 & 0 & 0 \\
Sumaca & $2(0,8)$ & $940(76,4)$ & $968(66,7)$ & $546(34,7)$ & $331(29,3)$ & $78(13,8)$ & $25(7,1)$ \\
Vapor & 0 & $1(0,1)$ & $105(7,3)$ & $484(30,8)$ & $423(37,4)$ & $356(62,9)$ & $217(61,8)$ \\
Total & $240(100,0)$ & $1.229(100,0)$ & $1.450(100,0)$ & $1.571(100,0)$ & $1.129(100,0)$ & $566(100,0) 351(100,0)$ \\
\hline
\end{tabular}

FONTE: Jornal do Commércio, meses de março, setembro, outubro e novembro, 1827-1888.

Biblioteca Nacional, Rio de Janeiro, RJ.

Segundo a tabela $3^{35}$, de 1830 a 1859, grande parte das embarcações eram sumacas $^{36}$, passando, posteriormente, a prevalecer os vapores. Como decorrência de tal mudança, o tempo de duração das viagens diminuiu.

Além do fator tempo, houve uma variação de tonelagem ${ }^{37}$. No caso das sumacas, houve um predomínio de tonelagem entre 40-49, respondendo por 693 (26,8\%) embarcações e, seguido por 582 (22,5\%) barcos com 60 a 69 toneladas. Enquanto isso, os vapores apresentavam, preponderantemente, a tonelagem entre 60-69, correspondendo a 348 (28,2\%) barcos, e 263 (21,2\%) embarcações com 80 a 89.

\footnotetext{
${ }^{35}$ As embarcações foram contadas uma única vez.

${ }^{36}$ Segundo Cunha (1982, p. 743), sumaca era antigo navio à vela. Ferreira (1986, p. 1.628) definiu sumaca como barco semelhante ao patacho, porém menor.

37 Tonelagem é entendida como a capacidade interna de uma embarcação (cf. FERREIRA, 1986, p. 1.688).
} 
Por conseguinte, os vapores eram embarcações de maior porte, o que amenizava o impacto causado pela grande queda verificada no movimento portuário local. Em termos de carregamento, transportavam mais quantidade de mercadorias. Entretanto, também a circulação desse tipo de barco, no litoral sul-fluminense, diminuiu a partir de 1860 .

A queda na saída de embarcações pelo litoral, independentemente de ter vindo acompanhada pela mudança do tipo de barco, promoveu a diminuição do fluxo de homens, pelos caminhos abertos em direção ao interior, desestruturando todo o sistema que vinha junto à cabotagem. Sobre a cabotagem realizada entre os portos brasileiros, sabemos que:

“o comércio através da navegação de cabotagem propiciou, ainda, o aumento da oferta de empregos assalariados. Mestres de embarcações, marinheiros, caixeiros de negociantes circulavam constantemente na rota do comércio. Parte da população livre encontrou maiores oportunidades de ganhar o seu sustento no manejo dos pontos de pernoite que se formaram no percurso das tropas. Forneciam alimentação, lugar para dormir, foragem para os animais” (MARTINHO \& GORENSTEIN, 1993, p. 167).

A diminuição das saídas pelos portos esteve associada à construção da Estrada de Ferro D. Pedro II que, em 1864, chegou a Barra do Piraí, em 1871, a Barra Mansa e, em 1877, a Queluz (EL-KAREH, 1982).

A produção cafeeira que era até então escoada pelos portos do litoral sulfluminense passou a ser transportada por via férrea, oferecendo aos seus usuários, mais rapidez e segurança. Além disso, a estrada de ferro

"rompia com os antigos parâmetros de localização e velocidade, ou seja, mexia com o espaço e o tempo; mais concretamente, a ferrovia era capaz de transportar grandes quantidades de carga entre Rio e São Paulo, deixando para trás as antigas trilhas e estradas de barro, com suas tropas, cavalos e liteiras. Estas continuaram a ser utilizadas, porém perderam seu papel de transporte dominante" (MACHADO, s.d., p. 28).

Processo semelhante ocorreu no litoral norte paulista, particularmente no porto ubatubense, que conheceu uma redução de seu movimento, associada à “construção das 
estradas de ferro que comunicavam todas as regiões produtoras com o porto de Santos" (FERNÁNDEZ, 1992, p. 68).

Examinando as cargas transportadas pelas embarcações saídas do litoral sulfluminense, na tabela 2, notamos que a diminuição do movimento portuário esteve associada à redução do café como carga. O café, embora tenha continuado a ser o principal carregamento, foi perdendo importância desde os anos de 1860, para o transporte da aguardente. Por exemplo, em Angra, nos anos entre 1860 e 1869, o café foi transportado por $81,2 \%$ dos barcos que chegaram ao Rio de Janeiro e a aguardente por $11,5 \%$. Nos anos entre 1870 e 1879, 47,5\% trouxeram café ao porto carioca, enquanto $37,1 \%$ carregaram aguardente (cf. TABELA 2).

Vinculado à queda do escoamento do café, a partir de 1870, “em Angra dos Reis, os casarões assobradados que tinham depósitos de café na parte térrea, foram sendo abandonados e começaram a ruir" (CAPAZ, 1996, p. 202). Destino semelhante tiveram as estradas que conduziam as produções até o litoral, como as de Ariró, de Mambucaba e de Parati (CAPAZ, 1996, p. 203).

Ao lado desse fator, podemos citar o término do tráfico de escravos, em 1850. Com isso, grosso modo, ocorreu o encarecimento da mão-de-obra escrava, gerando dificuldades por parte dos pequenos produtores escravistas na obtenção de trabalhadores, levando muitos, inclusive, a vender seus escravos para o tráfico interno ${ }^{38}$.

Na década de 1880, havia em Angra um pequeno cultivo de cana-de-açúcar e o café, ainda plantado em Mambucaba e Ilha Grande, rendia ao município apenas 40.000 quilos, com preços de quatro mil réis (4\$000) para cada 10 quilos (LIMA, 1872, p. 127).

A aguardente continuava a ser fabricada. Mambucaba, em 1889, possuía quatro engenhos, produzindo em torno de 600 pipas anuais (LIMA, 1972, p. 175); na Ilha Grande havia seis engenhos, com fabricação de 700 pipas anuais (LIMA, 1972, p. 183); na Ribeira, 15 engenhos, dando, anualmente, 1.500 pipas de aguardente (LIMA, 1972, p. 195); e em Jacuecanga, 10 engenhos produziam 1.200 pipas anuais (LIMA, 1972, p. 203).

Naqueles anos, o município lançou uma campanha para a construção de uma estrada de ferro, "para que o município de Angra dos Reis erga-se do abatimento em que

\footnotetext{
${ }^{38}$ Segundo Castro, a segunda metade do século XIX caracterizou-se no Brasil "pelo recrudescimento do número de brancos empobrecidos, nas diversas situações rurais, locais e regionais” (CASTRO, 1995, p. 104).
} 
se acha e dê vida aos municípios vizinhos” (LIMA, 1972, p. 130). Para tal, contava-se com a sensibilidade do governo, para conceder a Estrada de Ferro do Cruzeiro à cidade de Angra 39 .

Estas e outras propostas visaram à recuperação da economia, mas pouco ou nada foi feito, acelerando uma “estagnação” econômica que começou a ser revertida na década de 1920.

Portanto, os laços familiares que serão tratados nos próximos capítulos foram formados num contexto de expansão das atividades econômicas em Angra, durante a primeira metade do século XIX e, posteriormente, num gradativo quadro de crise, caracterizado pela diminuição do movimento portuário. Observamos, a seguir, de que forma a economia atingiu a demografia livre e escrava.

${ }^{39}$ A estrada levaria todos os produtos do norte da província de São Paulo e do sul de Minas Gerais até o porto de Angra, percorrendo uma distância não superior a 125 quilômetros. 


\section{CAPÍTULO 2-EVOLUÇÃO DA POPULAÇÃO LIVRE E ESCRAVA}

A evolução da população livre e, mais detalhadamente, a escrava é o tema tratado. Acompanhamos, ainda, alguns dados demográficos como a razão de sexo e a faixa etária dos cativos, entre outros.

Sabemos que o Oitocentos foi marcado por mudanças econômicas na localidade. Essas mudanças, sem dúvida, atingiram os percentuais de livres e de escravos; em particular, o de escravos. Acreditamos que, em meio as dificuldades para manter suas atividades, muitos homens e mulheres livres se viram na necessidade de vender alguns de seus cativos. Outros, devido ao elevado preço dos escravos verificado na segunda metade do século XIX, tiveram grandes dificuldades em recorrer ao tráfico interno. Logo, o número de cativos diminuiu.

Nós entendemos este movimento decrescente como um indício do grau em que estavam as atividades produtivas locais, ou seja, em processo de contínua crise.

Para demonstrar tal processo, há fontes que cobrem os anos entre 1840 e 1872. Os documentos analisados foram as estimativas populacionais presentes nos relatórios de presidentes de província do Rio de Janeiro de 1841, de 1851 e de 1858, onde constaram os dados para os anos de 1840, de 1850 e de 1856, respectivamente. Contamos, igualmente, com o Censo Nacional de $1872^{40}$.

\footnotetext{
${ }^{40}$ Todos os dados levantados devem ser entendidos como estimativas, visto que havia uma dificuldade na contagem dos habitantes do Brasil Império. Sobre isso, Botelho (1998a), em seu estudo sobre a demografia brasileira no século XIX, afirmou que os comandantes de ordenanças, os capitães-mores e, em seguida, os juízes de paz e subdelegados foram os responsáveis pela contagem da população em toda a colônia e depois no império. Essas atividades eram realizadas sem remuneração e sem nenhum tipo de especialização ou treino. Com a racionalização do censo, ao longo do século XIX, o levantamento começou a ser feito por burocratas da Corte (BOTELHO, 1998a, p. 64-65). Acerca do primeiro Recenseamento Geral do Império, do ano de 1872, Botelho (1998a, p. 70) localizou uma série de problemas.
} 


\section{TABELA 4}

População livre e escrava existente nas freguesias de Angra dos Reis, 1840-1872

\begin{tabular}{|c|c|c|c|c|c|c|c|c|}
\hline \multirow[t]{2}{*}{ Freguesia } & \multicolumn{2}{|c|}{1840} & \multicolumn{2}{|c|}{1850} & \multicolumn{2}{|c|}{1856} & \multicolumn{2}{|c|}{1872} \\
\hline & $\begin{array}{l}\text { Livres } \\
\mathrm{n}^{\circ}(\%)\end{array}$ & $\begin{array}{c}\text { Escravos } \\
n^{\circ}(\%)\end{array}$ & $\begin{array}{l}\text { Livres } \\
\mathrm{n}^{\circ}(\%)\end{array}$ & $\begin{array}{c}\text { Escravos } \\
n^{\circ}(\%)\end{array}$ & $\begin{array}{l}\text { Livres } \\
\mathrm{n}^{\circ}(\%)\end{array}$ & $\begin{array}{r}\text { Escravos } \\
n^{\circ}(\%)\end{array}$ & $\begin{array}{l}\text { Livres } \\
\mathrm{n}^{\circ}(\%)\end{array}$ & $\begin{array}{r}\text { Escravos } \\
n^{\circ}(\%)\end{array}$ \\
\hline $\mathrm{C}$ & $3.52653,5)$ & $3.063(46,5)$ & $4.796(59,6)$ & $3.254(40,4)$ & $5.087(62,9)$ & $2.998(37,1)$ & $5.482(78,7)$ & $1.482(21,3)$ \\
\hline IG & $3.464(52,4)$ & $3.147(47,6)$ & $4.661(58,7)$ & $3.283(41,3)$ & $5.421(65,1)$ & $2.900(34,9)$ & $6.062(80,0)$ & $1.512(20,0)$ \\
\hline $\mathrm{R}$ & $3.791(55,5)$ & $3.040(44,5)$ & $3.495(59,1)$ & $2.417(40,9)$ & $4.006(61,9)$ & $2.462(38,1)$ & $3.694(77,5)$ & $1.073(22,5)$ \\
\hline M & $1.269(49,4)$ & $1.302(50,6)$ & $1.784(53,9)$ & $1.526(46,1)$ & $2.092(61,7)$ & $1.299(38,3)$ & $2.051(81,1)$ & $477(18,9)$ \\
\hline Total & $12.050(53,3)$ & $10.552(46,7)$ & $14.736(58,4)$ & $10.480(41,6)$ & $16.606(63,2)$ & $9.659(36,8)$ & $17.289(79,2)$ & $4.544(20,8)$ \\
\hline
\end{tabular}

FONTES: Relatórios de Presidentes de Província do Rio de Janeiro, 1841, 1851 e 1858. Biblioteca Nacional, Rio de Janeiro, RJ. Censo Nacional de 1872. Instituto Brasileiro de Geografia e Estatística (IBGE), Rio de Janeiro, RJ.

NOTAS: C=Conceição; IG=Ilha Grande; R=Ribeira; M=Mambucaba. Os dados de 1872 relativos à freguesia de Jacuecanga foram somados aos da freguesia da Conceição.

Houve um predomínio de livres sobre os escravos em todos os anos analisados e em todas as freguesias, ocorrendo, inclusive, um aumento numérico ${ }^{41}$.

Nos anos de 1840, a distribuição de livres e escravos, nas freguesias, foi, ligeiramente equilibrada, tendo o município 46,7\% de escravos ${ }^{42}$. No ano de 1850, a participação dos livres aumentou e a de escravos se reduziu. No ano de 1856, os livres já representavam 63,2\% da população total, percentual que chegou, em 1872, a 79,2\%.

A elevação numérica da população livre foi observada antes mesmo de 1840. Segundo Marcondes (1995), o litoral sul-fluminense conheceu um aumento de habitantes livres desde 1780. Dividindo por subperíodos, o autor constatou que o grupo “outros”, grupo no qual a região em estudo fazia parte, chegou a uma taxa geométrica anual média de 0,55\%, entre 1780 e 1821, e 1,29\%, entre 1821 e 1840 (MARCONDES, 1995, p. 259).

Confrontando os percentuais encontrados para o município de Angra, observamos que, o peso dos escravos sobre o total populacional, foi menor que o calculado para Mangaratiba, onde os percentuais foram de 56,2\%, em 1840; 49,4\%, em 1850; 41,3\%, em

\footnotetext{
${ }^{41}$ A freguesia de Jacuecanga foi criada na década de 1850 e informações relativas a ela só apareceram no Censo de 1872. Antes, o seu território compreendia parte da extensão da freguesia da Conceição de Angra dos Reis. Optamos pelo somatório dos dados das freguesias da Conceição de Angra dos Reis e de Jacuecanga.

${ }^{42}$ Percentual maior que o encontrado, por exemplo, na cidade do Recife, em 1828, onde $31 \%$ da população era escrava (cf. CARVALHO, 1998, p. 51).
} 
1856; e 22,1\%, em $1872^{43}$. Já, em Parati, os cativos representaram, respectivamente, $37,7 \%, 34,9 \%, 27,7 \%$ e $16,9 \%{ }^{44}$ do contingente populacional.

No ano de $1872^{45}$, o percentual de 20,8\% de escravos existentes em Angra ${ }^{46}$ foi menor do que o encontrado para Capivary ${ }^{47}$, estimado em 22\% da população (CASTRO, 1987, p. 41). Foi abaixo, também, do encontrado para Magé, área especializada no abastecimento interno da Corte, onde os escravos representaram 39,6\% (SAMPAIO, 1994, p. 144). Em Paraíba do Sul, região produtora de café, os escravos estavam em torno de 48,0\% (RIOS, 1990, p. 21). Na província do Piauí, o percentual de escravos chegou a 11,77\% (KNOX, 1993, p. 31). E, em Juiz de Fora e Muriaé, áreas produtoras de café da Zona da Mata Mineira, havia, respectivamente, 37\% e 20\% de escravos (ANDRADE, 1995, p. 74).

A evolução populacional pode ser vista mediante a verificação das taxas de crescimento anual, presentes na tabela 5 .

A taxa calculada para população livre foi de 2,02\%, entre 1840 e 1856. Tal crescimento esteve, possivelmente, relacionado ao contexto econômico favorável, com a atividade portuária e a existência de armazéns de café, estimulando a ida de homens livres vinculados ao comércio da rubiácea, para a localidade. Por exemplo, a freguesia de Mambucaba apresentou a maior taxa, 3,17\%. Nesta localidade a atividade de escoamento do café por meio do porto local foi de suma importância, havendo um núcleo urbano comparável com o existente no centro de Angra (LIMA, 1972). Este crescimento foi visto, também nas freguesias da Ilha Grande e da Conceição de Angra dos Reis. Um ritmo menor foi verificado na Ribeira, com uma taxa de 0,34\%. Esta freguesia, contraditoriamente, também contava com importante atividade associada ao escoamento do café, e também do cultivo desse produto e de cana.

\footnotetext{
${ }^{43}$ Vale destacar que os dados relativos ao ano de 1872 excluíram as crianças nascidas a partir da Lei do ventre livre (1872). Com certeza a não contagem dos ingênuos colaborou para a queda numérica dos cativos.

${ }^{44}$ Relatórios de Presidentes de Província do Rio de Janeiro, de 1841, 1851 e 1858 e o Censo Nacional de 1872. Fontes localizadas na Biblioteca Nacional e no Instituto Brasileiro de Geografia e Estatística (IBGE). Rio de Janeiro, RJ.

${ }^{45}$ Os escravos representavam 37,46\% da população de toda a província do Rio de Janeiro, no ano de 1872 (BOTELHO, 1998a, p. 79).

${ }^{46}$ A escravaria angrense correspondeu a 1,3\% de todos os cativos existentes na Corte e na Província do Rio de Janeiro (cf. SILVA, 1992, p. 355).

${ }^{47}$ Atual Município de Silva Jardim, estado do Rio de Janeiro.
} 
TABELA 5

Taxas de crescimento anual da população livre e escrava existentes nas freguesias de Angra dos Reis, 1840-1872

\begin{tabular}{c|c|c|c|c}
\hline Freguesias & $\begin{array}{c}1840-1856 \\
\text { Livre } \\
\%\end{array}$ & $\begin{array}{c}1840-1856 \\
\text { Escrava } \\
\%\end{array}$ & $\begin{array}{c}1856-1872 \\
\text { Livre } \\
\%\end{array}$ & $\begin{array}{c}1856-1872 \\
\text { Escrava } \\
\%\end{array}$ \\
\hline C & 2,31 & $-0,13$ & 0,47 & $-4,30$ \\
IG & 2,89 & $-0,50$ & 0,70 & $-3,98$ \\
R & 0,34 & $-1,30$ & 0,50 & $-5,05$ \\
M & 3,17 & $-0,01$ & 0,12 & $-6,06$ \\
Total & 2,02 & $-0,55$ & 0,25 & $-4,60$ \\
\hline
\end{tabular}

FONTES: Relatórios de Presidentes de Província do Rio de Janeiro, 1841, 1851 e 1858. Biblioteca Nacional, Rio de Janeiro, RJ. Censo Nacional de 1872. Instituto Brasileiro de Geografia e Estatística (IBGE), Rio de Janeiro, RJ.

NOTAS: C=Conceição; IG=Ilha Grande; R=Ribeira; M=Mambucaba. Os dados de 1872 relativos à freguesia de Jacuecanga foram somados aos da freguesia da Conceição.

O ritmo de crescimento dos habitantes livres, verificado entre 1840-1856, não se repetiu entre 1856 e 1872. Neste intervalo, a taxa de crescimento anual foi de 0,25\%.

Isto é, se no intervalo anterior houve um aumento de livres, podendo, inclusive, estar vinculado a uma migração para a localidade, nos anos da segunda metade, esta elevação ficou longe do que se viu. Vale lembrar que a diminuição da taxa de crescimento anual ocorreu num período em que a economia local estava numa gradativa crise. Possivelmente houve a saída daqueles indivíduos ligados ao transporte e à comercialização do café.

A queda da taxa ocorreu em quase todas as freguesias: em Mambucaba, a taxa calculada foi a maior das encontradas para Angra nos anos de 1840-1856: já nos anos de 1856-1872, foi a menor. A freguesia estava num momento de abatimento econômico mais intenso que as demais. Não por acaso foi considerada por Lima (1972, p. 173), em 1889, a mais pobre de Angra dos Reis. Embora fosse a maior em superfície, foi a que contava com menor número de habitantes, 3.800, no ano de 1889 (LIMA, 1972, p. 174). Já a Ribeira, por sua vez, apresentou uma taxa de crescimento ligeiramente acima que a verificada para os anos entre 1840 e 1856.

A taxa anual de crescimento dos livres de Angra, entre 1840 e 1856, foi menor que a encontrada em Parati e em Mangaratiba. Na primeira, a população livre cresceu a uma taxa anual de 2,67\% e, na segunda, a 3,56\%. Nos anos de 1856 a 1872, as taxas 
foram, respectivamente, de $0,94 \%$ e de $0,08 \%{ }^{48}$. Ou seja, o ritmo de crescimento visto nos anos de 1840 a 1856 foi comum a todo o litoral sul-fluminense e o movimento ascendente reduzido entre 1856 e 1872, também.

O movimento populacional dos livres foi comum aos três municípios do litoral, estando associado ao fato de que nas ditas localidades, seus habitantes dedicavam-se às atividades semelhantes. Nas três houve um intenso movimento portuário, na primeira metade do século XIX, assim como uma crise econômica, ao longo da segunda metade do século.

Já a evolução numérica dos escravos foi totalmente diferente ao que se viu entre os livres. Houve um decréscimo dos cativos. Este movimento não foi visto por Marcondes (1995), entre 1780 e 1821. Naqueles anos a taxa geométrica anual média do grupo “outros" foi de $1,15 \%$ e, entre 1821 e 1840 , foi de $0,59 \%{ }^{49}$.

Entre 1840 e 1856, o índice de crescimento de escravos em Angra foi de -0,55\%. O decréscimo ocorreu em todas as freguesias. Menor impacto foi observado para Mambucaba, com uma taxa de -0,01\%. Esta freguesia apresentou o maior indicador de crescimento de livres, naqueles anos. Portanto, os anos citados foram mais favoráveis para a localidade. A Ribeira, por sua vez, além de ter tido a menor proporção de crescimento anual de livres foi a que teve o maior de decréscimo de escravos, $-1,30 \%$.

Mesmo estando num momento relativamente favorável à economia local, a população escrava de Angra já apresentava, nestes anos, um movimento de decréscimo. Entretanto, a redução foi mais intensa nos anos entre 1856 e 1872.

Em anos de ausência de novos africanos devido ao término do tráfico externo de escravos (1850) e por uma reposição de mão-de-obra, via reprodução natural e o tráfico interno, os escravistas de Angra não estavam conseguindo garantir e, muito menos, repor os trabalhadores que se "perdiam". Nestes anos a taxa foi de $-4,60 \%{ }^{50}$.

\footnotetext{
${ }^{48}$ As taxas de crescimento anual apresentadas foram calculadas a partir dos dados presentes nos Relatórios de Presidentes de Província do Rio de Janeiro de 1841 e de 1858 e o Censo Nacional de 1872. As fontes foram localizadas na Biblioteca Nacional e no Instituto Brasileiro de Geografia e Estatística (IBGE), no Rio de Janeiro, RJ.

${ }^{49}$. Os números encontrados para o grupo "outros" ficaram, apenas, à frente dos localizados para o "Rio", enquanto as maiores taxas foram calculadas para as regiões cafeicultoras (MARCONDES, 1995, p. 259).

${ }^{50}$ A taxa de decréscimo dos escravos em Angra foi maior que a localizada, por exemplo, entre 1856-1872, para Capivary, calculada em menos 2,65\%. A contagem foi feita a partir dos números oferecidos por Castro (1987, p. 41).
} 
O decréscimo no número de escravos foi comum a várias localidades, principalmente naquelas dedicadas ao abastecimento interno, na segunda metade do século XIX (SAMPAIO, 1994, p. 145). Em Capivary, por exemplo, “entre 1856 e 1872, a população escrava do município decresceu de 5.999, cerca de 40\% do total recenseado, para 3.903, 22\% do conjunto da população” (CASTRO, 1987, p. 41).

Em Magé, em oposição, a escravaria conheceu um crescimento, passando de 5.770 (42,99\%), em 1856, para 7.418 (39,59\%), em 1872 (SAMPAIO, 1994, p. 144). Sobre o dito município, Sampaio (1994) localizou este movimento na freguesia de Guapimirim, localidade que estava vivendo um momento de criação e/ou expansão do sistema agrícola; enquanto as freguesias de Piedade e Suruí seguiram a tendência de diminuição do contingente escravo (SAMPAIO, 1994, p. 146). E, finalmente, a província do Espírito Santo conheceu um aumento em números absolutos e percentuais ${ }^{51}$, possuindo, em 1856, 12.269 (25\%) escravos, e, em 1872, 22.552 (27,5\%) cativos (ALMADA, 1984, p. 69).

A diminuição numérica de escravos ocorreu em todo o litoral sul-fluminense. Em Parati, entre 1840 e 1856, a taxa de crescimento anual dos escravos foi de -0,23\% e, entre 1856 e 1872, de -2,93\%. Em Mangaratiba foram, respectivamente, $-0,24 \%$ e $-5,44 \%{ }^{52}$.

A redução do número de escravos em Angra esteve associado à incapacidade do sistema escravista local em manter e repor sua mão-de-obra, principalmente, na segunda metade do século XIX. Por exemplo, entre os anos de 1856 e 1840, Mambucaba apresentou um elevado aumento de livres e o menor decréscimo de escravos. Isso esteve vinculado ao porto existente na localidade. Entre 1872 e 1856, a freguesia teve um aumento de livres bem reduzido e o maior decréscimo de escravos. Na Ilha Grande, observamos um incremento no crescimento de livres e uma diminuição no decréscimo de cativos. Esta freguesia era distante da atividade portuária, onde a diminuição do

\footnotetext{
${ }^{51}$ O crescimento esteve associado à expansão cafeeira que, em 1872, havia substituído a cana-de-açúcar (cf. ALMADA, 1984 p. 68).

${ }^{52}$ As taxas de crescimento anual apresentadas foram calculadas a partir dos dados presentes nos Relatórios de Presidentes de Província do Rio de Janeiro de 1841 e de 1858 e o Censo Nacional de 1872. As fontes foram localizadas na Biblioteca Nacional e no Instituto Brasileiro de Geografia e Estatística (IBGE). Enquanto o litoral sul-fluminense vivia um decréscimo do número de escravos, na província do Rio de Janeiro houve, entre 1872 e 1850, um crescimento anual de 2,86 cativos (BOTELHO, 1998a, p. 75).
} 
movimento do porto não provocou maiores impactos, ao contrário das freguesias do continente.

O desaparecimento dos cativos teve como motivos altas taxas de mortalidade, alforrias, fugas ou vendas deles para as áreas de ponta na economia imperial.

Sobre um dos motivos para a diminuição do número de escravos no município, o Jornal do Commércio aponta para um processo de saída de cativos de Angra. Acompanhando os dados relativos às entradas de embarcações no porto carioca, o referido jornal informava o número e o nome dos passageiros que vinham nas embarcações, incluindo “escravos a entregar”. Entre 1830 e 1839, chegaram ao Rio de Janeiro, 88 “escravos a entregar”; entre 1840 e 1849, 198; entre 1850 e 1859, 459; entre 1860 e 1869, 531; nos anos de 1870 a 1879, 380, incluindo cinco ingênuos; e de 1880 até 1888, 22 cativos.

A expressão “escravos a entregar” pode indicar a venda de cativos. Pelo que parece, aqueles estavam sendo conduzidos a seus novos donos. Se isso for verdade, podemos afirmar que muitos escravistas estavam vendendo seus cativos. No entanto, uma dúvida: os escravos que chegavam ao porto do Rio de Janeiro provinham do litoral ou do interior? Poderiam ter sido apenas embarcados pelos portos do litoral sul-fluminense, mas tinham sua procedência para além da serra. Mesmo com as observações e dado a grande perda em números de escravos, é seguro que estavam aí, entre os “escravos a entregar”, alguns, ou muitos, dos cativos desaparecidos no censo de 1872.

Tal processo não parece duvidoso, em função do contexto econômico vivenciado na localidade e o processo, grosso modo, de encarecimento da mão-de-obra após a abolição do tráfico externo de escravos, em $1850^{53}$.

\footnotetext{
${ }^{53}$ Em estudo sobre o meio urbano e rural do Rio de Janeiro, Florentino concluiu: "Entre 1799 e 1870, os cativos adultos do campo e da cidade tiveram seus preços nominais multiplicados por 8 e por 18, respectivamente. Os valores de meninos e meninas (0-14 anos de idade) cresceram de 10 a 17 vezes - de 7 a 14 vezes, no caso dos escravos com mais de 40 anos. Em libras esterlinas, adultos, crianças e pretos velhos tornaram-se de três a cinco vezes mais caros entre 1810 e 1870” (FLORENTINO, 2005, p. 341).
} 
TABELA 6

Razão de sexo da população escrava existente nas freguesias de Angra dos Reis, 1840-1872

\begin{tabular}{c|c|c|c|c}
\hline Freguesias & 1840 & 1850 & 1856 & 1872 \\
\hline C & 125 & 113 & 115 & 86 \\
IG & 135 & 121 & 125 & 103 \\
R & 128 & 129 & 125 & 102 \\
M & 138 & 128 & 148 & 115 \\
Total & 130 & 122 & 124 & 98 \\
\hline
\end{tabular}

FONTES: Relatórios de Presidentes de Província do Rio de Janeiro, 1841, 1851 e 1858. Biblioteca Nacional, Rio de Janeiro, RJ. Censo Nacional de 1872. Instituto Brasileiro de Geografia e Estatística (IBGE), Rio de Janeiro, RJ.

NOTAS: C=Conceição; IG=Ilha Grande; R=Ribeira; M=Mambucaba; J=Jacuecanga. Os dados de 1872 relativos à freguesia de Jacuecanga foram somados aos da freguesia da Conceição. A Razão encontrada para Jacuecanga em 1872 foi de 87 e para Conceição, de 85 .

O ritmo decrescente da empresa escravista, anteriormente apontado pela diminuição do peso de escravos sobre a população total, é confirmado pela razão de sexo (tabela 6). Para a afirmação, partimos da constatação de que a razão de sexo é uma boa medida da capacidade de investimento da empresa escravista, vista pela compra de escravos homens em idade produtiva. É verdade que os dados apresentados não especificam a faixa etária dos envolvidos, mas, de qualquer forma, é visto uma queda no número de homens ${ }^{54}$.

Em 1840, a razão de sexo foi de 130; em 1850, 122; em 1856, 124; e em 1872, 98. A freguesia da Conceição de Angra apresentou, em todos os anos, a menor razão de sexo, chegando, em 1872, a 86. Esta localidade, correspondendo ao atual centro de Angra, era uma área onde havia intensa atividade urbana, com intensa participação feminina.

Ocorreu, então, em Angra uma queda da razão de sexo, principalmente, na segunda metade do século XIX, exatamente quando observamos uma redução percentual de escravos no município. Com isso, podemos pensar que houve um processo de venda de escravos do sexo masculino, por serem mais aceitos no mercado, ou que a reprodução natural foi, gradativamente, promovendo um equilíbrio entre os sexos. Na verdade, acreditamos na conjunção de ambos acontecimentos.

A razão de sexo vista em três dos quatro anos para Angra foi inferior àquela encontrada, por exemplo, em Magé. Nesta região, em 1850, a dita razão era de 165;

\footnotetext{
${ }^{54}$ Devemos recordar que os dados para os anos de 1872 não incluíram os ingênuos, tornados livres após a Lei do Ventre Livre.
} 
enquanto, que, em 1856, correspondia a 140 e, em 1872, a 112 (SAMPAIO, 1994, p. 148). Também foi menor que a localizada para Capivary, no ano de 1872, correspondendo a 111,3 (CASTRO, 1987, p. 42), e inferior aos 134 homens para 100 mulheres, vista no Paraíba do Sul, em 1872 (RIOS, 1990, p. 21).

Logo, Angra, além de ter reduzido percentual de escravos, em 1872, se comparado a algumas localidades da província do Rio de Janeiro, também detinha menor razão de sexo. Ou seja, a empresa escravista angrense passava por dificuldades.

\section{TABELA 7}

Razão de sexo da população escrava entre 15 e 40 anos existente nas freguesias de Angra dos Reis, 1872

\begin{tabular}{c|c}
\hline Freguesias & 1872 \\
\hline $\mathrm{C}$ & 89 \\
$\mathrm{IG}$ & 90 \\
$\mathrm{R}$ & 103 \\
$\mathrm{M}$ & 104 \\
Total & 93 \\
\hline
\end{tabular}

FONTE: Censo Nacional de 1872. Instituto Brasileiro de Geografia e Estatística (IBGE), Rio de Janeiro, RJ.

NOTAS: C=Conceição; IG=Ilha Grande; R=Ribeira; M=Mambucaba; J=Jacuecanga. Os dados de 1872 relativos à freguesia de Jacuecanga foram somados aos da freguesia da Conceição. A razão de sexo calculada para Jacuecanga foi de 101 e, para Conceição, de 82.

A razão de sexo na faixa etária adulta, entre escravos de 15 a 40 anos, em 1872, foi ainda menor que a verificada naquele ano (cf. tabela 6). A razão encontrada na tabela 7, de 93, demonstra uma ligeira predominância das mulheres. O equilíbrio numérico entre homens e mulheres foi observado na Ribeira, onde a razão foi de 103, chegando a 104 em Mambucaba. Na Ilha Grande, a razão de sexo foi de 90. E unindo-se os dados da Conceição com a de Jacuecanga, encontramos 89.

Dos escravos existentes em Angra, desde a década de 1850, já havia uma predominância dos crioulos sobre os africanos. Entre 1856 e 1872, o percentual dos cativos nascidos no Brasil elevou-se. 


\section{TABELA 8}

Origem dos escravos localizados nas freguesias de Angra dos Reis, 1856 e 1872

\begin{tabular}{c|lr|lrr}
\hline Freguesias & \multicolumn{2}{|c|}{1856} & $\begin{array}{r}\text { Africanos } \\
\mathrm{n}^{\circ}(\%)\end{array}$ & $\begin{array}{l}\text { Crioulos } \\
\mathrm{n}^{\circ}(\%)\end{array}$ & $\begin{array}{r}\text { Africanos } \\
\mathrm{n}^{\circ}(\%)\end{array}$ \\
\hline $\mathrm{C}$ & $1.888(63,0)$ & $1.110(37,0)$ & $1.215(82,0)$ & $267(18,0)$ \\
$\mathrm{n}(\%)$ & $1.851(63,8)$ & $1.049(36,2)$ & $1.211(80,1)$ & $301(19,9)$ \\
R & $1.595(67,8)$ & $867(35,2)$ & $945(88,1)$ & $128(11,9)$ \\
M & $709(54,6)$ & $590(45,4)$ & $397(83,2)$ & $80(16,8)$ \\
Total & $6.043(62,6)$ & $3.616(37,4)$ & $3.768(82,9)$ & $776(17,1)$ \\
\hline
\end{tabular}

FONTES: Relatório de Presidente de Província do Rio de Janeiro de 1858. Biblioteca Nacional, Rio de Janeiro, RJ. Censo Nacional de 1872. Instituto Brasileiro de Geografia e Estatística (IBGE), Rio de Janeiro, RJ.

NOTAS: C=Conceição; IG=Ilha Grande; R=Ribeira; M=Mambucaba; J=Jacuecanga. Os dados de 1872 relativos à freguesia de Jacuecanga foram somados aos da freguesia da Conceição. Naquele ano havia em Jacuecanga 411 crioulos e 76 africanos.

A prevalência de cativos oriundos do Brasil foi visível desde 1856, quando a influência do tráfico de escravos ainda era forte nas diversas localidades do Brasil. Em Magé, por exemplo, 50,24\% dos cativos, em 1856, eram africanos (SAMPAIO, 1994, p. 155).

Desde princípios da segunda metade do século XIX, Angra estava vivenciando o que denominamos “crioulização”. Esse comportamento foi observado em todas as freguesias.

A “crioulização” foi maior em Magé, onde o número de escravos nascidos no Brasil chegou a 89,08\%, em 1872 (SAMPAIO, 1994, p. 155). Perfil diferente foi visto em Paraíba do Sul, onde havia, mais ou menos, um terço de africanos, entre 1865 e 1870 (FRAGOSO \& FLORENTINO, 1987, p. 159).

A diminuição de africanos e o aumento percentual de crioulos apontam, mais uma vez, para a venda de escravos (geralmente homens, muitos dos quais africanos) ou para falecimentos, ou para a reprodução interna que promoveu uma “crioulização" da escravaria. Tais acontecimentos geraram uma queda da razão de sexo.

Em Mambucaba, em 1856, o percentual de africanos foi de 45,4\%, o maior dos encontrados para as freguesias. Esta mesma localidade teve uma razão de sexo de 148, também a maior das calculadas. Sabendo-se que, entre a população africana, a freqüência de homens tendeu a ser maior, em decorrência da preferência que o tráfico externo de africanos dava aos cativos do sexo masculino, concluímos que a maior participação de 
homens naquela freguesia, no ano de 1856, esteve associada à presença de africanos. Esta freguesia contava também com a maior taxa de crescimento de adultos.

Sobre os informes encontrados até agora para Angra, deduzimos que estava ocorrendo mais do que um processo de "crioulização", a formação de uma comunidade escrava que tinha uma origem comum, um histórico de antepassados africanos, porém de profunda vivência geracional na senzala.

\section{TABELA 9}

Procedências dos escravos crioulos existentes nas freguesias de Angra dos Reis, 1872

\begin{tabular}{c|c|c|c|c|c}
\hline Freguesias & $\begin{array}{c}\text { Rio de Janeiro } \\
\mathrm{n}^{\circ}(\%)\end{array}$ & $\begin{array}{c}\text { Sudeste } \\
\mathrm{n}^{\circ}(\%)\end{array}$ & $\begin{array}{c}\text { Nordeste } \\
\mathrm{n}^{\circ}(\%)\end{array}$ & $\begin{array}{c}\text { Sul } \\
\mathrm{N}^{\circ}(\%)\end{array}$ & $\begin{array}{c}\text { Total } \\
\mathrm{n}^{\circ}(\%)\end{array}$ \\
\hline $\mathrm{C}$ & $1.057(94,6)$ & $19(1,7)$ & $41(3,7)$ & 0 & $1.117(100,0)$ \\
IG & $1.210(99,9)$ & 0 & $1(0,1)$ & 0 & $1.211(100,0)$ \\
R & $928(98,3)$ & $8(0,8)$ & $8(0,8)$ & $1(0,1)$ & $945(100,0)$ \\
M & $391(98,5)$ & $2(0,5)$ & $4(1,0)$ & 0 & $397(100,0)$ \\
Total & $3.586(97,7)$ & $29(0,8)$ & $54(1,5)$ & $1(0,1)$ & $3.670(100,0)$ \\
\hline
\end{tabular}

FONTE: Censo Nacional de 1872. Instituto Brasileiro de Geografia e Estatística (IBGE), Rio de Janeiro, RJ. NOTAS: C=Conceição; IG=Ilha Grande; R=Ribeira; M=Mambucaba. Os dados relativos a freguesia de Jacuecanga foram somados aos da freguesia da Conceição. Em Jacuecanga foram encontrados 409 cativos provenientes do Rio de Janeiro e dois do Nordeste. Não foram contabilizados 98 cativos devido à ausência de informações acerca de suas procedências, todos escravos existentes na Conceição.

Dos crioulos de 1872, grande parte tinha nascido na província do Rio de Janeiro, correspondendo a 3.586 (97,7\%) escravos. Em segundo, vinham os cativos do Nordeste, respondendo por 54 (1,5\%); em terceiro, os do Sudeste, somando 29 ou 0,8\%; e em último, um cativo do Sul, ou 0,1\%.

O percentual de cativos originados do Rio de Janeiro foi semelhante ao encontrado para Magé — 95,43\% dos escravos tinham sua origem na própria província em que viviam e trabalhavam (SAMPAIO, 1994, p. 155).

A origem dos crioulos resultou da compra por parte dos proprietários mais enriquecidos ou, o que parece mais plausível, da reprodução natural. Entretanto, mais uma vez, reforçamos a idéia, tal como apontado por Sampaio (1994), da existência de uma comunidade escrava que vinha se formando, caracterizada por cativos nascidos no Brasil, ou mais precisamente, na própria província. Sobre Magé, disse Sampaio (1994, p. 157-158), 
“A pequena participação de africanos em sua população e o fato de serem quase todos os crioulos nascidos no Rio de Janeiro dava-lhes uma grande unidade cultural e devia também traduzir-se num forte sentimento de pertencimento a uma comunidade, com vivências e valores bastante semelhantes, pois forjados em realidades igualmente próximas”.

TABELA 10

Faixas etárias dos escravos existentes nas freguesias de Angra dos Reis, 1856

\begin{tabular}{c|cccc|c|c}
\hline Faixas etárias & $\begin{array}{c}\mathrm{C} \\
\mathrm{n}^{\circ}(\%)\end{array}$ & $\begin{array}{c}\mathrm{IG} \\
\mathrm{n}^{\circ}(\%)\end{array}$ & $\begin{array}{c}\mathrm{R} \\
\mathrm{n}^{\circ}(\%)\end{array}$ & $\begin{array}{c}\mathrm{M} \\
\mathrm{n}^{\circ}(\%)\end{array}$ & $\begin{array}{c}\text { Total } \\
\mathrm{n}^{\circ}(\%)\end{array}$ \\
\hline $0-7$ & $412(14,1)$ & $464(16,0)$ & $364(14,8)$ & $196(15,1)$ & $1.436(15,0)$ \\
$7-14$ & $412(14,1)$ & $425(14,7)$ & $315(12,8)$ & $161(12,4)$ & $1.313(13,7)$ \\
$15-40$ & $1.204(41,3)$ & $1.244(42,9)$ & $715(29,0)$ & $665(51,2)$ & $4.180(43,7)$ \\
41 ou mais & $884(30,4)$ & $767(26,4)$ & $715(29,0)$ & $277(21,3)$ & $2.643(27,6)$ \\
Total & $2.912(100,0)$ & $2.900(100,0)$ & $2.461(100,0)$ & $1.299(100,0)$ & $9.572(100,0)$ \\
\hline
\end{tabular}

FONTE: Relatório de Presidente de Província do Rio de Janeiro de 1858. Biblioteca Nacional, Rio de Janeiro, RJ. NOTAS: C=Conceição; IG=Ilha Grande; R=Ribeira; M=Mambucaba. Não foram calculados 87 cativos em função da ausência de informações sobre suas idades.

No ano de 1856, os idosos corresponderam a 27,6\% dos 9.572 cativos; as crianças, de zero a 14 anos, representaram 28,7\%; e os adultos, 43,7\%. Portanto, havia um predomínio de cativos considerados mais aptos ao trabalho ou, em tese, mais valiosos ${ }^{55}$.

A maior participação de escravos adultos foi localizada na freguesia de Mambucaba. Os escravos de 15 a 40 anos chegaram a 51,2\%; 27,5\% dos cativos eram crianças, de zero a 14 anos; e, 21,3\% tinham mais de 41 anos. Foi esta mesma localidade que apresentou nesse ano, o maior percentual de africanos e de razão de sexo. Parece-nos, portanto, que a escravaria de Mambucaba, no ano de 1856, era preparada para atividades agrícolas e a mais valiosa, dentre as existentes nas outras freguesias.

\footnotetext{
${ }^{55}$ Diversos estudos que trabalharam com os preços dos cativos observaram que os adultos valiam mais que as crianças e os idosos. Entretanto, outras variáveis também determinaram os preços, por exemplo, o sexo, as condições de saúde e as especializações (cf. TEIXEIRA, 2001).
} 
TABELA 11

Faixas etárias dos escravos existentes nas freguesias de Angra dos Reis, 1872

\begin{tabular}{c|c|c|c|c|c}
\hline Faixas etárias & C & IG & R & M & Total \\
& $\mathrm{n}^{\circ}(\%)$ & $\mathrm{n}^{\circ}(\%)$ & $\mathrm{n}^{\circ}(\%)$ & $\mathrm{n}^{\circ}(\%)$ & $\mathrm{n}^{\circ}(\%)$ \\
\hline $0-10$ & $389(26,7)$ & $140(9,3)$ & $315(30,6)$ & $114(23,9)$ & $958(21,4)$ \\
$11-15$ & $78(5,4)$ & $81(5,4)$ & $109(10,6)$ & $44(9,2)$ & $312(7,0)$ \\
$16-40$ & $749(51,5)$ & $561(37,1)$ & $347(33,7)$ & $196(41,1)$ & $1.853(41,5)$ \\
41 ou mais & $238(16,4)$ & $729(48,2)$ & $257(25,1)$ & $123(25,8)$ & $1.347(30,1)$ \\
Total & $1.454(100,0)$ & $1.511(100,0)$ & $1.028(100,0)$ & $477(100,0)$ & $4.470(100,0)$ \\
\hline
\end{tabular}

FONTE: Censo Nacional de 1872. Instituto Brasileiro de Geografia e Estatística (IBGE), Rio de Janeiro, RJ. NOTAS: C=Conceição; IG=Ilha Grande; R=Ribeira; $M=$ Mambucaba. Os dados relativos a Jacuecanga foram somados aos da Conceição. Em Jacuecanga havia 84 escravos com até 10 anos; 30 com 11 a 15 anos; 287 com 16 a 40 anos; e 82 com 41 anos ou mais. Não foram incluídos na tabela dados relativos a 74 cativos pois não havia informações acerca de suas idades.

Entre 1856 e 1872, o perfil etário dos cativos foi pouco alterado. No ano de 1872, os adultos corresponderam a 41,5\%, os idosos representaram 30,1\% e as crianças, de zero a 15 anos, $28,4 \%{ }^{56}$.

A freqüência de crianças sobre o total dos escravos manteve-se estável, o de adultos sofreu uma pequena diminuição e o de idosos, uma ligeira elevação percentual. Na Ilha Grande, por exemplo, os idosos representaram 26,4\% e 48,2\% dos cativos, respectivamente, em 1856 e em 1872.

A população escrava de Angra estava envelhecendo, visto que o único percentual que aumentou, entre 1856 e 1872, foi o dos cativos de 41 anos ou mais. O envelhecimento atingiu, possivelmente, os cativos de origem africana, já que, no ano de 1872, havia se passado 22 anos da abolição do tráfico de escravos e, portanto, de suspensão da entrada de cativos de “além-mar”.

O percentual de adultos, representando sempre o maior na comparação com os demais, comprovava a existência de proprietários locais que conseguiram garantir a manutenção de uma mão-de-obra apta ao trabalho. No entanto, em geral, houve uma certa incapacidade do sistema na manutenção da escravidão no município. O dado é

\footnotetext{
${ }^{56}$ A distribuição das faixas etárias nas tabelas 10 e 11 estiveram condicionadas à distribuição dos informes nas respectivas fontes. Por isso as idades usadas para as crianças entre 1856 e 1872 sofreram uma pequena alteração. Sobre os números das crianças em 1872, por certo houve subnumeração, visto que os ingênuos não foram contados.
} 
confirmado pelas elevadas taxas de dependência para os anos de 1856 e 1872, respectivamente, 1,28 e $1,41^{57}$.

Em 1856 e em 1872, 28\% dos cativos tinham até 14 anos. Esse percentual foi menor que os localizados por GUTIÉRREZ (1986, p. 116), em estudo sobre o Paraná, por exemplo. Lá, as crianças, consideradas até os 15 anos, corresponderam a 40,5\%, em 1798; 39,8\%, em 1810; 39,6\%, em 1824; e 37,0\% em 1836. Em Magé, nos anos de 18501851, 1870-1871 e 1885-1886, respectivamente, as crianças representaram 22,73\%, 33,33\% e 21,01\% do total de escravos (SAMPAIO, 1994, p. 158).

O percentual de crianças, em torno de $28 \%$, e o gradativo equilíbrio entre os sexos na segunda metade do século XIX, são indícios de uma reprodução natural, comum não apenas ao município, mas a diversas localidades, como Minas Gerais e Magé. Ao mesmo tempo, verificamos um distanciamento do mercado, no caso, do tráfico interno ${ }^{58}$.

Portanto, a diminuição do número de cativos atingiu, principalmente, os homens, muitos deles africanos e em idade adulta. Possivelmente, houve um processo de venda de escravos para fora do município ${ }^{59}$. Dito de outra forma, a venda foi um dos destinos dos escravos que viviam em Angra, provavelmente encaminhados as áreas cafeeiras do vale do Paraíba.

A venda teria atingido, em menor volume, as crianças e os idosos. Os primeiros, em torno de seus dez anos, estariam aptos a realizar algumas atividades e os idosos, embora com reduzida capacidade produtiva, poderiam ainda trabalhar, caso não sofressem de uma grave doença.

\footnotetext{
${ }^{57}$ A taxa de dependência no ano de 1856 foi maior que a de Magé, correspondente a 0,85. Ver Sampaio (1994, p. 159).

${ }^{58}$ Florentino e Góes (2005) foram alguns dos diversos autores que afirmaram que a diminuição da aquisição de escravos via mercado promoveu, gradativamente, a redução percentual de adultos e de homens. Ao mesmo tempo, gerou um equilíbrio numérico de crianças. Trabalhando com o meio rural do Rio de Janeiro, observaram que o desequilíbrio entre os sexos variava de acordo com as flutuações do tráfico Atlântico, sendo que, em tempos de desembarques, a diferença aumentava (FLORENTINO \& GÓES, 2005, p. 210). Em fazendas que, por vinte anos, não compravam cativos, o equilíbrio sexual era comum e as crianças correspondiam a 1/3 dos cativos. Nas propriedades que não adquiriram escravos via compra a 50 anos, as crianças poderiam chegar a metade de todos os escravos (FLORENTINO \& GÓES, 2005, p. 210).

${ }^{59}$ A tendência, na segunda metade do século XIX de envio de escravos dos pequenos senhores, de vilas e de outras regiões do Brasil rumo às áreas de grande lavoura foi citada por Castro (1995, p. 38).
} 
Além da venda, as alforrias contribuíram para a diminuição da escravaria local ${ }^{60}$.

Segundo Castro (1997, p. 360), muitos senhores do Sudeste alforriaram seus cativos:

"Ao contrário do que se poderia esperar, num contexto de escassez de mãode-obra, as alforrias se multiplicaram ao longo da segunda metade do século XIX. Há o fato de que a instituição escravista sofria uma perda progressiva de legitimidade. Mas há também a circunstância de que se tornava perigoso, para os senhores, frustrar as expectativas do trânsito para a liberdade dos próprios cativos”.

Dos inventários de escravistas disponíveis para Angra dos Reis, em 24 encontramos a prática da alforria na segunda metade do século XIX ${ }^{61}$. Joaquina Maria de Jesus, em seu testamento, libertou três dos seus 20 escravos. Os mesmos foram citados como forros no seu inventário de $1863^{62}$.

Outros escravos devem ter falecido, pois sabemos que elevadas taxas de mortalidade foram comuns entre cativos no Brasil (SCHWARTZ, 1995, p. 303-308).

Enfim, o século XIX, de modo geral, foi caracterizado por dois momentos: o primeiro, até meados do século, definido como de estímulo à economia, baseado, por exemplo, na atividade portuária. O segundo, desenhado gradativamente ao longo da segunda metade do século, entendido como de crise econômica. Esta foi calcada na diminuição do movimento portuário, no fechamento dos armazéns de café localizados no litoral e mais dificuldades no acesso ao trabalhador cativo, provocadas pelo fim do tráfico Atlântico. Os acessos ao tráfico interno e à reprodução natural teriam amenizado a falta de braços. Entretanto, os escravistas locais não foram intensos compradores de cativos provenientes do tráfico interno.

\footnotetext{
${ }^{60}$ Alguns estudos constataram que as mulheres escravas, as crianças e os adultos jovens foram os mais beneficiados com a alforria. Isto foi visto em Campos no século XVIII por Faria (1998, p.107). As mulheres foram preferenciais nas alforrias concedidas no Recife, nos anos de 1827 e de 1842, correspondendo, respectivamente, a 60,8\% e 54,4\%, dos libertos (CARVALHO, 1998, p. 222). Em Salvador, entre 1684 e 1745, foram duas mulheres para cada homem liberto (SCWARTZ, 2001, p. 184).

${ }^{61}$ Em 17 inventários, datados de 1800 até 1848, houve escravos sendo alforriados.

${ }^{62}$ Os escravos alforriados foram João, de nação Moçambique, com 70 anos, sua esposa Luzia, de nação Benguela, com 60 anos, e Teresa, de nação Rebolo, com 55 anos. Inventário de Joaquina Maria de Jesus, 1863. Museu da Justiça do Estado do Rio de Janeiro, RJ.
} 
A segunda metade do século foi definidora não apenas para Angra, mas para o sistema escravista brasileiro. Naqueles anos foram aprovadas leis que trataram diretamente do emprego da mão-de-obra como a Lei do Ventre Livre, de 1871. Esta deixava livre toda criança nascida de ventre escravo a partir de 28 de setembro de $1871^{63}$ e criava o Fundo de Emancipação para libertação dos cativos. Na verdade, os ingênuos poderiam ser empregados pelos senhores de suas mães até a idade de $21 \operatorname{anos}^{64}$. Foi aprovada também a Lei dos Sexagenários, de 1885, libertando os escravos com mais de 60 anos. Em 1869 foi aprovada a lei que proibia a separação das famílias escravas por vendas ou doações.

Portanto, ao longo do século XIX houve um movimento numérico decrescente de escravos, principalmente na segunda metade do século, paralelamente à queda da razão de sexo e da presença de africanos. Em oposição, aumentou o percentual de crioulos, muitos deles nascidos na província e, quiçá, no próprio município.

Os cativos constituíram uma comunidade cada vez mais envelhecida e formada por crianças que, da mesma forma que garantiram a formação de laços parentais, ofereceram aos seus proprietários a esperança de reporem as perdas de braços, sofridas naqueles anos.

As transformações ocorridas na segunda metade do século foram intensas, por exemplo, em Mambucaba. A freguesia, nos anos entre 1840 e 1856, teve a maior taxa de crescimento anual de livres e a menor taxa de decréscimo de escravos. Em 1856, 45,4\% dos escravos eram africanos, 51,2\% eram adultos e existiam 148 homens para cada cem mulheres. Ou seja, a escravaria da localidade, dentre as existentes em Angra, era, em tese, a mais apta ao trabalho e considerada mais valiosa. Nessa freguesia, a atividade portuária foi intensa, existiam armazéns de café, cultivos de café e de cana, além de diversas famílias francesas e agentes consulares franceses que, além de Mambucaba, se instalaram em outras regiões do Brasil no século XIX. A fixação dos mesmos esteve vinculada à importância comercial das áreas e, no caso de Mambucaba, relacionou-se à comercialização do café do vale do Paraíba (cf. VASCONCELLOS, 2001, p. 58).

\footnotetext{
${ }^{63}$ Sobre a Lei do Ventre Livre ver, entre outros: Pena (2001) e Brandão (1996).

${ }^{64}$ Diversos inventários de Angra dos Reis, datados de 1872 em diante, indicaram na avaliação dos bens, valores para os serviços dos ingênuos.
} 
Entretanto, entre 1856 e 1872, a taxa de crescimento anual de livres foi a menor das calculadas para as freguesias, além da maior taxa de decréscimo de escravos. Em 1872, o percentual de africanos foi o mais baixo dos encontrados, embora ainda houvesse maior razão de sexo e um dos mais representativos percentuais de cativos adultos. Nesse período, o movimento portuário já havia perdido importância e os cafezais diminuíram (cf. VASCONCELLOS, 2001, p. 99). A freguesia estava num quadro de abatimento econômico e, ligado a ele, o ritmo de crescimento numérico de livres foi menos intenso. As atividades produtivas locais não estavam conseguindo manter seus cativos, embora houvesse senhores que possuíam escravos homens e em idade adulta. Em 1889, a freguesia foi considerada a mais pobre das existentes em Angra (LIMA, 1972).

Finalmente, visando obtermos um panorama da economia e da demografia, analisamos no próximo capítulo os inventários, o que nos possibilitou elaborar um mapeamento da economia da região e da distribuição de escravos nas propriedades. 


\section{CAPÍTULO 3-MAPEAMENTO ECONÔMICO E ESTRUTURA DE POSSE DE ESCRAVOS}

Trabalhamos com os processos relativos à Angra dos Reis, no século XIX, existentes no Museu da Justiça do Rio de Janeiro.

Dividimos os inventários entre os seguintes subperíodos: de 1800-1815; de 18161826; de 1827-1837; de 1838-1848; de 1849-1859; 1869-1871; e de 1872-1888. Entretanto, utilizamos também dois grandes recortes temporais, de 1800 até 1848 e entre 1849 e 1888.

Duzentos e cinqüenta inventários foram localizados, sendo que 228 (91,2\%) citaram a presença de escravos.

\section{TABELA 12}

Número de propriedades, de escravos e de ingênuos constantes nos inventários post-mortem, por subperíodos.

Angra dos Reis, 1800-1888

\begin{tabular}{c|c|c|c|c|c|c|c|c}
\hline & $1800-1815$ & $1816-1826$ & $1827-1837$ & $1838-1848$ & $1849-1859$ & $1860-1871$ & $1872-1888$ & Total \\
\hline Propriedades & 5 & 15 & 31 & 37 & 45 & 62 & 33 & 228 \\
\% Propriedades & 2,2 & 6,6 & 13,6 & 16,2 & 19,7 & 27,2 & 14,5 & 100,0 \\
Escravos & 23 & 182 & 435 & 479 & 443 & 890 & 234 & 2686 \\
\% Escravos & 0,8 & 6,8 & 16,2 & 17,8 & 16,6 & 33,1 & 8,7 & 100,0 \\
Ingênuos & 0 & 0 & 0 & 0 & 0 & 0 & 32 & 32 \\
\% Ingênuos & & & & & & & 100,0 & 100,0 \\
\hline
\end{tabular}

FONTES: Inventários post-mortem de escravistas de Angra dos Reis, 1800-1888. Museu da Justiça do Estado do Rio de Janeiro, RJ.

Dispomos de fontes para todos os subperíodos, destacando-se os documentos abertos entre 1849-1859 e entre 1860-1871.

Dos anos de 1800 até 1848, encontramos 88 (38,6\%) processos e, entre 1849 e $1888^{65}, 140$ (61,4\%). A representatividade documental para a segunda metade do século resultou na maior amostragem de escravos, $58,3 \%{ }^{66}$.

\footnotetext{
${ }^{65}$ Entre os processos datados de 1888, foram anotados os documentos abertos até 13 de maio pois, após esta data os escravos não fizeram mais parte do patrimônio, visto que se tornaram livres com a Lei Áurea, assinada pela Princesa Isabel. Para informações acerca da lei, ver, entre outros: Daibert Júnior (2004).

${ }^{66}$ A maior quantidade de inventários na segunda metade do século XIX resultou da disponibilidade documental existente no acervo do Museu da Justiça. Além de que, documentos "mais recentes” estão menos vulneráveis aos efeitos do tempo.
} 
A fim de analisar a evolução das propriedades escravas ao longo dos anos, efetuamos o cálculo da média de escravos por senhores: entre 1800-1816, a média encontrada foi de 4,6 cativos; nos anos de 1816 até 1826, 12,1; já entre 1827 e 1837, 14,0; e nos tempos de 1838 até 1848, 12,9; enquanto de 1849 a 1859, 9,8; por idos de 1860 a 1871, 14,3; e por fim, entre 1872 e 1888, 8,1.

Durante o período de 1816 a 1848, as escravarias, em média, possuíam mais de 10 cativos, correspondendo às propriedades de médio porte. Entre 1849-1859, a média chegou a 9,8; contudo, no subperíodo seguinte elevou-se para 14,3. No último subperíodo a queda foi visível, pois existiam 8,1 cativos por senhores ${ }^{67}$.

A redução em finais do período escravista era esperada: em primeiro lugar, porque os escravos acima dos 60 anos e, posteriormente, com mais de 65 anos, foram libertos pela Lei dos Sexagenários ou Lei Saraiva-Cotegipe; e, em segundo, porque aquele período caracterizou-se por um intenso esvaziamento numérico nas escravarias, resultante de alforrias concedidas, de vendas, de falecimentos e de fugas.

No entanto, 22 processos não foram contabilizados na tabela 12. Entre 1800 e 1848, três, e entre 1849 e 1888, 19 inventários não citaram a existência de escravos. A maior presença de não escravistas na segunda metade dos oitocentos resultou, possivelmente, da dificuldade em adquirir cativos, visto que o preço dos mesmos atingiu valores elevados, após o término do tráfico de escravos, em 1850. Este dado confirma, também, o agravamento do momento econômico local, avaliado no capítulo 2, quando constatamos que o número de escravos reduziu-se consideravelmente.

Dentre os proprietários de escravos, predominaram os donos de até cinco cativos $^{68}$, totalizando 119 , de 1800 até 1888.

As pequenas escravarias foram comuns em outras áreas e recortes temporais. Esta constatação resultou das pesquisas realizadas a partir de 1980, colocando "por terra" afirmações consideradas, até então, como "verdades históricas": a de que no Brasil, grande parte dos senhores de escravos eram donos de muitas "almas"69.

\footnotetext{
${ }^{67}$ Para o cálculo da média após 1872 incluímos os ingênuos, resultantes da Lei do Ventre Livre ou Lei Rio Branco, de 28 de setembro de 1871.

${ }^{68}$ Ver tabela 13.

${ }^{69}$ O principal autor reavaliado foi Prado Júnior pois considerava que o exemplo típico de propriedade era o latifúndio, dedicado à monocultura que contava com muitos escravos. Esta afirmação era aplicada tanto à área rural quanto à mineradora (PRADO JÚNIOR, 1972, p.117-185).
} 
A revisão sobre o tema da estrutura de posse de escravos iniciou-se com os estudos sobre Minas Gerais e mostrou que os senhores com até cinco trabalhadores eram os mais freqüentes. Por exemplo, no ano de 1804, em São Caetano, 70,2\% dos escravistas detinham até cinco cativos; em Serro do Frio, em 1738, chegaram a 78,4\% (COSTA \& LUNA, 1982, p. 38). O mesmo perfil foi encontrado em Vila Rica, em 1804 (COSTA, 1979, p. 185).

Os pesquisadores dedicaram-se também à análise das listas nominativas de habitantes, disponíveis para São Paulo. Dentre outros, o estudo de 25 localidades de São Paulo, congregando áreas de diferentes economias, como o vale do Paraíba, a Capital, o Oeste Paulista, o Caminho do Sul e o Litoral, nos anos de 1777, 1804 e 1829, encontrou uma ampla participação de propriedades com até cinco escravos, com percentuais que variavam de 60 a 70\%, excepcionando o Oeste Paulista, quando em 1829, 57,1\% dos senhores detinham até cinco cativos (LUNA, 1998, p. 153).

Os escravistas de Lorena, no vale do Paraíba paulista, no ano de 1801, dedicados ao cultivo de gêneros de subsistência ou ao autoconsumo ${ }^{70}, 69,7 \%$ possuíam até cinco trabalhadores (COSTA \& NOZOE, 1989, p. 327). Na mesma localidade, nos anos de 1818 e de 1829, quando o café já estava sendo cultivado, os proprietários com até quatro escravos chegaram a, respectivamente, 57,1\% e 59,2\% (MARCONDES, 1998, p. 90-91).

Em Areias, São Paulo, os percentuais daquele perfil de escravistas foram de 69,1\%, em 1817; 66,8\%, no ano de 1822; 58,6\%, em 1829; e de 58,2\%, em 1836 (LUNA, 1995, p. 10). A redução percentual a partir de 1829 deve-se à proliferação do cultivo do café na localidade, que promoveu o aumento da participação de propriedades com 11 a 20 cativos. Em Bananal, os senhores possuidores de até quatro trabalhadores compulsórios corresponderam a 52,3\%, em 1801, antes da entrada do café na região; por 60,3\%, no ano de 1817, quando iniciou-se a cultura da rubiácea; e por 49,7\%, em 1829, quando o café já estava disseminado por toda a parte (MOTTA, 1999a , p. 168) ${ }^{71}$.

No distrito norte-mineiro, atual Bocaiúva, nos intervalos de 1831/1832 e de 1838/1840, quando a vida econômica local caracterizava-se por uma diversidade de

\footnotetext{
${ }^{70}$ A aguardente e toucinho eram gêneros de subsistência e arroz, milho, feijão e mandioca eram destinados ao autoconsumo (COSTA \& NOZOE, 1989, p. 320).

${ }^{71}$ Todos os autores citados utilizaram as listas nominativas de habitantes existentes para as respectivas áreas.
} 
cultivos e por um comércio ativo, houve "nítida concentração de proprietários escravistas na faixa de um a três escravos” (GODOY, 1992, p.69) ${ }^{72}$. Na freguesia urbana de São Cristóvão, no Rio de Janeiro, 78,6\% dos senhores ${ }^{73}$ tinham até cinco escravos, no ano de 1870 (MOTTA, NOZOE \& COSTA, s.d., p. 10). Após comparar os dados encontrados por diversas pesquisas dedicadas às mais variadas localidades, com diferentes características econômicas, em recortes temporais também diversos, Motta, Nozoe \& Costa (s.d., p. 50) terminaram seu artigo com a seguinte afirmação:

"Enfim se, como sabido, panos de fundo socioeconômicos distintos podem dar suporte a populações cujas estruturas demográficas apresentam perfis estatísticos em boa medida semelhantes, este é o caso do padrão de distribuição da propriedade escrava no Brasil dos séculos XVIII e XIX. Nesse padrão figuravam, de forma inequívoca, vale a pena repisar, como escravista majoritário, o que possuía poucos cativos (...)”

Portanto, o perfil de propriedade escrava existente em Angra reforça as conclusões apresentadas acima. Apresentamos, agora, a distribuição das faixas de tamanho de propriedades para os subperíodos.

TABELA 13

Faixa de tamanho de propriedades, por subperíodos. Angra dos Reis, 1800-1888

\begin{tabular}{c|c|c|c|c|c|c|c|c}
\hline FTP & $\begin{array}{c}1800-1815 \\
\mathrm{n}^{\mathrm{o}}(\%)\end{array}$ & $\begin{array}{c}1816-1826 \\
\mathrm{n}^{\circ}(\%)\end{array}$ & $\begin{array}{c}1827-1837 \\
\mathrm{n}^{\circ}(\%)\end{array}$ & $\begin{array}{c}1838-1848 \\
\mathrm{n}^{\circ}(\%)\end{array}$ & $\begin{array}{c}1849-1859 \\
\mathrm{n}^{\circ}(\%)\end{array}$ & $\begin{array}{c}1860-1871 \\
\mathrm{n}^{\circ}(\%)\end{array}$ & $\begin{array}{c}1872-1888 \\
\mathrm{n}^{\circ}(\%)\end{array}$ & $\begin{array}{c}\text { Total } \\
\mathrm{n}^{\circ}(\%)\end{array}$ \\
\hline $1-5$ & $4(80,0)$ & $6(40,0)$ & $14(45,2)$ & $18(48,6)$ & $27(60,0)$ & $30(48,5)$ & $20(60,6)$ & $119(52,2)$ \\
$6-10$ & 0 & $2(13,3)$ & $6(19,4)$ & $9(24,3)$ & $8(17,8)$ & $11(17,7)$ & $4(12,1)$ & $40(17,5)$ \\
$11-20$ & $1(20,0)$ & $4(26,7)$ & $2(6,4)$ & $4(10,8)$ & $3(6,7)$ & $11(17,7)$ & $5(15,2)$ & $30(13,2)$ \\
21 ou mais & 0 & $3(20,0)$ & $9(29,0)$ & $6(16,3)$ & $7(15,5)$ & $10(16,1)$ & $4(12,1)$ & $39(17,1)$ \\
Total & $5(100,0)$ & $15(100,0)$ & $31(100,0)$ & $37(100,0)$ & $45(100,0)$ & $62(100,0)$ & $33(100,0)$ & $228(100,0)$ \\
\hline
\end{tabular}

FONTES: Inventários post-mortem de escravistas de Angra dos Reis, 1800-1888. Museu da Justiça do Estado do Rio de Janeiro, RJ.

NOTAS: FTP=faixa de tamanho de propriedade. Entendemos como pequenas propriedades as formadas por até cinco cativos; as médias congregavam de seis a vinte escravos; e as grandes, com 21 ou mais trabalhadores.

Ao longo dos anos, todas as faixas de tamanho de propriedades oscilaram, ora aumentando, ora diminuindo sua participação, em percentuais.

\footnotetext{
${ }^{72}$ Godoy (1992) também trabalhou com listas nominativas, existentes para Minas Gerais.

${ }^{73}$ Os autores fizeram uso de um arrolamento da população do município do Rio de Janeiro, no ano de 1870.
} 
Encontramos pouca alteração quando separamos os dados entre os anos de 18001848 e de 1849-1888: no primeiro intervalo de tempo, as escravarias com até cinco cativos representaram 47,7\%; os donos de seis a 10 escravos corresponderam a $19,3 \%$; $12,5 \%$ dos senhores tinham de 11 a 20 cativos; e 20,5\%, 21 ou mais escravos. No segundo intervalo, os percentuais calculados foram, respectivamente, 55,0\%, 16,4\%, 13,6\% e 15,0\%. Ou seja, os senhores com até cinco escravos foram comuns na primeira e na segunda metade do século XIX. Podemos ir além e afirmar que a representatividade daquele perfil de propriedade aumentou após 1850.

Congregando os plantéis e dividindo-os entre pequenas (1-5 escravos), médias (620) e grandes (21 ou mais) propriedades, percebemos que as primeiras continuaram a ser predominantes, seguidas pelas segundas; já as últimas responderam por 20,0\% de 1800 1815; entre 1816 e 1826, chegaram a 40,0\%; de 1827 até 1837, 25,8\%; de 1838-1848, 35,1\%; entre 1849 e 1859, 24,5\%; de 1860 a 1871, 35,4\%; e de 1872-1888, 27,3\%. No intervalo da pesquisa, entre 1800 e 1888, 30,7\% dos escravistas possuíam entre seis e vinte trabalhadores compulsórios.

Portanto, em Angra, as pequenas propriedades escravas eram as mais comuns, seguidas pelas médias. As grandes foram menos freqüentes, diminuindo, inclusive, percentualmente, após 1849.

Dentre as grandes propriedades são dignas de nota três escravarias que se destacaram pelo número de cativos: a primeira pertencia a Cândido Teixeira de Carvalho. Em seu inventário, aberto no ano de 1871, constavam 126 escravos. Ele possuía terras, casas, engenhos, ranchos para guardar canoas, plantações de café, mandioca, frutas e milho, na Enseada da Estrela, na freguesia da Ilha Grande. Na freguesia da Conceição, atual centro de Angra, ele era proprietário de casas e de prédios. Quando de sua morte, tinha dinheiro e dez apólices da dívida pública. Com certeza, era dono de um dos maiores patrimônios localizados, totalizando cem contos, duzentos e dezoito mil e quatrocentos e dezessete réis (100:218\$417).

O segundo maior escravista encontrado foi José da Silva Guimarães, cujo inventário foi iniciado no ano de 1847. Todos os seus bens estavam localizados em Mambucaba e eram formados por 127 escravos, terras, casas, engenhos, olaria, plantações de café e semoventes. Seu patrimônio somava sessenta e um contos, 
oitocentos e trinta e oito mil e seiscentos e quarenta réis (61:838\$640). No entanto, ao contrário do senhor Cândido, José da Silva Guimarães possuía uma dívida passivaa ${ }^{74}$, 30\% acima do valor de seus bens.

O Comendador José Francisco da Silva, em seu inventário de 1862, era senhor de 139 escravos, além de terras, casas térreas e de sobrado na freguesia da Conceição, engenho, rancho para tropas, serraria, além de estabelecimentos comerciais, dentre lojas de fazendas e negócios secos e molhados, nas freguesias de Mambucaba e da Ribeira ${ }^{75}$.

Sabemos que o pequeno proprietário era o típico modelo de senhor angrense. Cabem, agora, as perguntas: quais as atividades econômicas realizadas pelos escravistas e, também, pelos não escravistas, no momento de abertura de seus inventários? Será que suas ocupações eram semelhantes aos informes oferecidos pelos viajantes do século XIX, pelo Almanak Laemmert e pelos historiadores locais ${ }^{76}$ ?

A tabela 14 foi confeccionada tendo em mente a obtenção de respostas, sendo organizada a partir de todas as informações que havia nos processos ${ }^{77}$.

\footnotetext{
${ }_{75}^{74}$ Dívidas que o inventariado tinha que pagar a outrem.

${ }^{75}$ Os inventários nos quais havia avaliação de escravos estão distribuídos da seguinte forma: 31 processos contavam com apenas um escravo; 27 , com dois; 28 , com três; 19 , com quatro; 14, com cinco; oito, com seis cativos; 10, com sete escravos; oito, com oito trabalhadores; quatro, com nove; 10, com 10 escravos; quatro, com 11 cativos; um, com 12; seis, com 13 cativos; um, com 14; quatro, com 15; dois, com 16; quatro, com 17; dois, com 18; três, com 19; três, com 20; um, com 21; três, com 22; dois, com 23; um, com 24; dois, com 26; um, com 28; quatro, com 29; três, com 30; dois, com 32; um, com 33; um, com 34; um, com 38; três, com 39; dois, com 40; um, com 43; dois, com 44; um, com 50; um, com 51; um, com 54; um, com 57 escravos; um, com 126 cativos; um com 127; e, finalmente, um, com 139 escravos.

${ }^{76}$ Trabalhamos com as fontes indicadas no capítulo 1 .

77 Oitenta e oito inventários encontrados não tinham identificação das atividades realizadas pelos inventariados. Estes processos ficaram de fora da tabela 14. No entanto, existiram inventários que indicaram mais de uma atividade, por exemplo, a agricultura e a pesca. Nestes casos, os inventariados foram anotados duas vezes, uma vez como agricultores e a outra, como pescadores.
} 
TABELA 14

Atividades localizadas nos inventários de Angra dos Reis, entre 1800 e 1888

\begin{tabular}{|c|c|c|c|c|c|c|c|c|}
\hline Atividades & $\begin{array}{c}1800-1815 \\
n^{\circ}(\%)\end{array}$ & $\begin{array}{c}1816-1826 \\
n^{\circ}(\%) \\
\end{array}$ & $\begin{array}{c}1827-1837 \\
\mathrm{n}^{\circ}(\%) \\
\end{array}$ & $\begin{array}{c}1838-1848 \\
n^{\circ}(\%) \\
\end{array}$ & $\begin{array}{c}1849-1859 \\
\mathrm{n}^{\circ}(\%) \\
\end{array}$ & $\begin{array}{c}1860-1871 \\
\mathrm{n}^{\circ}(\%) \\
\end{array}$ & $\begin{array}{c}1872-1888 \\
\mathrm{n}^{\circ}(\%) \\
\end{array}$ & $\begin{array}{c}\text { Total } \\
\mathrm{n}^{\circ}(\%) \\
\end{array}$ \\
\hline Pesca & 0 & $6(31,6)$ & $8(21,6)$ & $9(20,9)$ & $7(18,4)$ & $17(25,8)$ & $11(23,9)$ & $58(23,1)$ \\
\hline Agricultura & $2(100,0)$ & $9(47,4)$ & $17(45,9)$ & $27(62,8)$ & $21(55,2)$ & $37(56,1)$ & $19(41,3)$ & $132(52,6)$ \\
\hline $\begin{array}{c}\text { Beneficiamento } \\
\text { açúcar }\end{array}$ & 0 & 0 & $3(8,1)$ & $4(9,3)$ & 0 & $4(6,1)$ & $2(4,4)$ & $13(5,2)$ \\
\hline $\begin{array}{l}\text { Beneficiamento } \\
\text { aguardente }\end{array}$ & 0 & $1(5,3)$ & $3(8,1)$ & $2(4,6)$ & $5(13,2)$ & $7(10,6)$ & $6(13,0)$ & $24(9,6)$ \\
\hline Ofícios & 0 & $1(5,3)$ & $3(8,1)$ & $1(2,3)$ & 0 & 0 & $2(4,4)$ & $7(2,7)$ \\
\hline Comércio & 0 & $2(10,5)$ & $3(8,1)$ & 0 & $5(13,2)$ & $1(1,4)$ & $6(13,0)$ & $17(6,8)$ \\
\hline Total & $2(100,0)$ & $19(100,0)$ & $37(100,0)$ & $43(100,0)$ & $38(100,0)$ & $66(100,0)$ & $46(100,0)$ & $251(100,0)$ \\
\hline
\end{tabular}

FONTES: Inventários post-mortem de Angra dos Reis, 1800-1888. Museu da Justiça do Estado do Rio de Janeiro, RJ.

Como era de se esperar, 52,6\% dos inventariados estavam vinculados ao cultivo da terra. Tratavam-se de inventários que indicavam plantações de café, mandioca, arroz, etc $^{78}$. Esta constatação não é nenhuma novidade, visto que o período exibe um Brasil eminentemente rural. Sendo assim, Angra dos Reis não poderia ser diferente do resto do Império.

As freguesias da Ilha Grande, de Mambucaba, da Ribeira e de Jacuecanga ${ }^{79}$ eram áreas onde a vida cotidiana circulava em torno da agricultura, ao contrário da freguesia da Conceição, mais comprometida com a “urbanidade”.

Cinqüenta e oito inventariados (23,1\%) exerciam funções vinculadas à pesca, utilizando suas redes de arrasto para recolher peixes, sardinhas, etc. Por meio da Baía da Ilha Grande, os moradores locais obtinham complemento alimentar. Grande era a variedade de peixes à disposição:

“garoupas, badejos, miras, merotes, parabijus, bijupirás, caranhas, robalos, cavalos, pampos, charéus, pescadas chernes, tainhas, vermelhos, paragicas, chereles, pargos, dourados, anchovas, bicudas, espadas, salgos, sardos, sororocas, caramburus, olhetes, olho de boi, pitangas, sarabiquaras, etc., não se falando nos paratis, carapebas, caratingas, galos, corcorocas, goreiras, goetes, salimas, gordinhos, sardinhas, etc” (LIMA, 1972, p.109)

\footnotetext{
${ }^{78}$ Veremos, mais adiante, os plantios indicados nos processos.

${ }^{79}$ Formada a partir de um desmembramento da freguesia de Nossa Senhora da Conceição de Angra dos Reis. Cf. capítulo 1 e 2.
} 
Também era por mar que se ia, muitas vezes, de uma freguesia a outra, de uma localidade à outra. Por isso, canoas foram indicadas em 127 inventários, ao lado de ranchos para “guardar canoas”, citados em 60 processos.

A produção de aguardente, fabricada em engenhocas, foi anotada em 9,6\% dos processos. A bebida era consumida tanto na localidade, quanto vendida fora da região ${ }^{80}$. Já a atividade comercial era a ocupação de 6,8\% dos inventariados. A maior parte destes homens possuíam um “pequeno” comércio. Oito viviam somente de seus negócios, sendo que quatro deles não eram escravistas.

Ludovina Maria Raymunda, após a morte de seu marido, o comerciante Joaquim Raymundo da Silva, deu início ao levantamento dos bens do casal. No ano de abertura do processo, 1874, a família possuía uma casa de vivenda onde funcionava um estabelecimento comercial, na freguesia da Ribeira. Além da casa e algumas mercadorias, havia uma mesa de jantar, algumas poucas louças e uma besta velha. A favor do casal existia uma dívida ativa no valor de um conto de réis, resultante de um crédito concedido a João Antônio de Oliveira, morador na Serra D’ Água, também na Ribeira. No entanto, a dívida foi considerada perdida. O que não estava perdido era um crédito com hipoteca e prêmios que o inventariado tinha adquirido em vida ${ }^{81}$. Esta dívida passiva ultrapassava o patrimônio da família.

A realidade contada no processo acima ilustra a situação de outro comerciante não escravista, que também perdeu seu patrimônio com pagamento de dívidas. Os outros dois não escravistas, por sua vez, conjugavam seus negócios com a concessão de empréstimos a terceiros $^{82}$. Existia, ainda, nove comerciantes que se dedicavam à agricultura, contando com a contribuição de seus escravos.

Dentre os inventariados havia sete $(2,7 \%)$ que possuíam algum ofício, sendo três sapateiros e quatro carpinteiros.

\footnotetext{
${ }^{80}$ Existiram embarcações saídas de Angra que chegaram ao Rio de Janeiro, com carregamento de aguardente. A bebida, produzida no município, também servia para abastecer o mercado carioca e outras localidades fluminenses.

${ }^{81}$ Inventário de Joaquim Raymundo da Silva, 1874. Angra dos Reis, RJ. Museu da Justiça do Estado do Rio de Janeiro, RJ.

${ }^{82}$ A prática de investimentos em empréstimos e a aquisição de apólices e títulos será analisada posteriormente.
} 
Comparando os dados para os subperíodos de 1800-1848 e de 1849-1888, constatamos que: a pesca foi citada em $22,8 \%$ dos processos, no primeiro subperíodo, e em 23,3\%, no segundo; a atividade agrícola foi indicada em 54,6\% e 51,3\%, respectivamente; o beneficiamento de açúcar era realizado por 6,9\% e 4,0\% dos inventariados, na primeira e na segunda metade dos oitocentos, respectivamente; o beneficiamento da aguardente apareceu em 5,9\% dos processos abertos até 1848 e 12,0\% dos inventários, após 1849; os inventariados com ofícios representaram 4,9\% dos documentos, entre 1800-1848, e 1,3\%, entre 1849-1888; e o comércio foi anotado em 4,9\% e 8,1\% dos inventários, respectivamente, entre 1800-1848 e entre 1849-1888.

Portanto, comparando-se os informes para a primeira e a segunda metade do século XIX, constatamos que o cultivo da terra e a pesca continuaram a ser as ocupações mais comuns à população angrense. No entanto, houve uma diminuição de inventários que indicaram a existência de engenhos de cana, aumentando a presença de engenhocas. Assim como aumentou também os inventários de comerciantes.

\section{TABELA 15}

Atividades citadas nos inventários de Angra dos Reis de escravistas e não escravistas, 1800-1888

\begin{tabular}{|c|c|c|c|c|c|}
\hline Atividades & $\begin{array}{c}\text { Não } \\
\text { escravistas } \\
\mathrm{n}^{\circ}(\%) \\
\end{array}$ & $\begin{array}{c}1-5 \\
\text { escravos } \\
\mathrm{n}^{\circ}(\%) \\
\end{array}$ & $\begin{array}{c}\text { 6-10 } \\
\text { escravos } \\
n^{\circ}(\%)\end{array}$ & $\begin{array}{c}11-20 \\
\text { escravos } \\
\mathrm{n}^{\circ}(\%)\end{array}$ & $\begin{array}{c}21 \text { ou mais } \\
\text { escravos } \\
n^{\circ}(\%)\end{array}$ \\
\hline \multicolumn{6}{|l|}{$1800-1848$} \\
\hline Pesca & 0 & $6(21,5)$ & $7(30,4)$ & $4(26,7)$ & $6(17,2)$ \\
\hline Agricultura & 0 & $18(64,3)$ & $14(60,8)$ & $8(53,3)$ & $15(42,9)$ \\
\hline $\begin{array}{l}\text { Beneficiamento } \\
\text { açúcar }\end{array}$ & 0 & $2(7,1)$ & 0 & 0 & $5(14,4)$ \\
\hline $\begin{array}{l}\text { Beneficiamento } \\
\text { aguardente }\end{array}$ & 0 & 0 & $1(4,4)$ & $2(13,3)$ & $3(8,5)$ \\
\hline Ofícios & 0 & $2(7,1)$ & 0 & 0 & $3(8,5)$ \\
\hline Comércio & 0 & 0 & $1(4,4)$ & $1(6,7)$ & $3(8,5)$ \\
\hline Total & 0 & $28(100,0)$ & $23(100,0)$ & $15(100,0)$ & $35(100,0)$ \\
\hline \multicolumn{6}{|l|}{ 1849-1888 } \\
\hline Pesca & $7(43,7)$ & $11(21,6)$ & $7(33,3)$ & $6(24,0)$ & $5(13,2)$ \\
\hline Agricultura & $4(25,0)$ & $33(64,7)$ & $11(52,4)$ & $12(48,0)$ & $17(44,7)$ \\
\hline $\begin{array}{l}\text { Beneficiamento } \\
\text { açúcar }\end{array}$ & 0 & 0 & 0 & 0 & $6(15,8)$ \\
\hline $\begin{array}{l}\text { Beneficiamento } \\
\text { aguardente }\end{array}$ & $1(6,3)$ & $2(3,9)$ & $1(4,7)$ & $6(24,0)$ & $8(21,0)$ \\
\hline Ofícios & 0 & $1(1,9)$ & 0 & $1(4,0)$ & 0 \\
\hline Comércio & $4(25,0)$ & $4(7,9)$ & $2(9,6)$ & & $2(5,3)$ \\
\hline Total & $16(100,0)$ & $51(100,0)$ & $21(100,0)$ & $25(100,0)$ & $38(100,0)$ \\
\hline
\end{tabular}

FONTES: Inventários post-mortem de Angra dos Reis, 1800-1888. Museu da Justiça do Estado do Rio de Janeiro, RJ. 
Nos anos de 1800-1848, todos os inventariados escravistas estavam vinculados à agricultura e à pesca. No entanto, a participação da primeira atividade diminuía à medida que aumentava a faixa de tamanho de propriedade. Da mesma forma, a existência de benfeitorias, como engenhos e engenhocas, era mais comum nas maiores propriedades. $\mathrm{O}$ comprometimento dos inventariados com o comércio era mais regular nas propriedade com seis ou mais cativos.

Portanto, quanto mais pobre o inventariado, maior ligação possuía com a cultura da terra e, ao contrário, quanto mais rico era o falecido, maior envolvimento com a

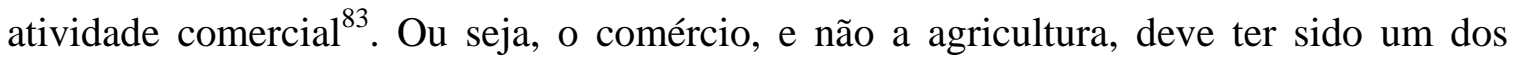
principais meios de enriquecimento em Angra. Junto ao comércio, os proprietários de 1800-1848 dedicavam-se à terra e adquiriam escravos.

Infelizmente, não foram encontrados documentos que permitissem verificar se os médios e os grandes escravistas começaram seu patrimônio com o comércio e depois foram investindo em terras e cativos. Mas esse processo pode ter ocorrido na localidade, confirmando conclusões apresentadas por outros estudos como, por exemplo, o de Fragoso (1992) que, pesquisando os grandes negociantes da praça mercantil do Rio de Janeiro, verificou que muitos acabaram optando por ter status. O ter status não era adquirido por meio do comércio, atividade considerada pouco honrosa, mas sim pela conversão da fortuna em terras e almas.

No entanto, podemos afirmar que a primeira metade do século XIX foi favorável às transações comerciais em Angra. A localidade, naqueles anos, foi pólo de escoamento do café do vale do Paraíba paulista e fluminense, por isso foram instalados armazéns de café ao longo do litoral angrense. Todos, ou quase todos, ganharam com o movimento de homens indo para o interior e vindo: uns lucraram mais e outros complementaram suas rendas, vendendo alimentos aos tropeiros. Enfim, foi, principalmente, o comércio que garantiu anos mais promissores à economia de Angra.

Todos os inventários datados da segunda metade do século XIX corroboram que a agricultura e a pesca foram atividades realizadas pelos falecidos. Também nesses anos as propriedades com menor número de escravos possuíam maior comprometimento com o

\footnotetext{
${ }^{83}$ Dos comerciantes, sete possuíam barcos ou sumacas.
} 
cultivo da terra. No entanto, o comércio apareceu como ocupação de inventariados com menor número de escravos e até mesmo por não escravistas. Sobre isso, consideramos duas explicações possíveis: a primeira pondera que a diminuição do movimento portuário, vista no capítulo 1, promoveu, de fato, uma desaceleração nas transações comerciais. Assim sendo, o enriquecimento de comerciantes tornou-se mais lento ou mais difícil. A segunda explicação está baseada na mudança de investimentos realizados por alguns dos donos de estabelecimentos comerciais, passando a investir em empréstimos e apólices, por exemplo. Ambas idéias são complementares, embora a primeira atinja diretamente a economia local.

Defendemos aqui, também, que a população de Angra dos Reis beneficiou-se, economicamente, mais da atividade comercial que da agricultura. Por isso, a segunda metade do século foi traumática para os angrenses, quando armazéns de café foram abandonados, após a chegada da Estrada de Ferro D. Pedro II ao vale do Paraíba.

TABELA 16

Relação de inventariados que possuíam apólices, eram credores e complementavam suas rendas com aluguéis de imóveis ou de escravos. Angra dos Reis, 1800-1888

\begin{tabular}{|c|c|c|c|c|c|c|c|c|}
\hline Atividades & $\begin{array}{c}1800-1815 \\
\mathrm{n}^{\circ}(\%)\end{array}$ & $\begin{array}{c}1816-1826 \\
\mathrm{n}^{\circ}(\%)\end{array}$ & $\begin{array}{c}1827-1837 \\
\mathrm{n}^{\circ}(\%)\end{array}$ & $\begin{array}{c}1838-1848 \\
\mathrm{n}^{\circ}(\%)\end{array}$ & $\begin{array}{c}1849-1859 \\
\mathrm{n}^{\circ}(\%)\end{array}$ & $\begin{array}{c}1860-1871 \\
\mathrm{n}^{\circ}(\%)\end{array}$ & $\begin{array}{c}1872-1888 \\
\mathrm{n}^{\circ}(\%)\end{array}$ & $\begin{array}{c}\text { Total } \\
\mathrm{n}^{\circ}(\%)\end{array}$ \\
\hline $\begin{array}{l}\text { Empréstimos e } \\
\text { créditos }\end{array}$ & 0 & $2(66,7)$ & $9(90,0)$ & $6(85,7)$ & $12(92,3)$ & $8(72,7)$ & $6(66,7)$ & $43(81,2)$ \\
\hline Aluguéis & 0 & $1(33,3)$ & $1(10,0)$ & $1(14,3)$ & $1(7,7)$ & 0 & $1(11,1)$ & $5(9,4)$ \\
\hline $\begin{array}{l}\text { Ações, apólices } \\
\text { da dívida pública }\end{array}$ & 0 & 0 & 0 & 0 & 0 & $3(27,3)$ & $2(22,2)$ & $5(9,4)$ \\
\hline Total & 0 & $3(100,0)$ & $10(100,0)$ & $7(100,0)$ & $13(100,0)$ & $11(100,0)$ & $9(100,0)$ & $53(100,0)$ \\
\hline
\end{tabular}

FONTES: Inventários post-mortem de Angra dos Reis, 1800-1888. Museu da Justiça do Estado do Rio de Janeiro, RJ. NOTA: Os inventariados indicados como credores foram aqueles que possuíam de quatro ou mais empréstimos concedidos para diferentes pessoas.

Alguns inventariados aplicaram seus bens em empréstimos, na aquisição de apólices e em aluguéis.

Das modalidades citadas, o empréstimo foi a mais comum, aparecendo em 81,2\% dos processos. Aluguéis e ações ou apólices representaram, respectivamente, 9,4\% e 9,4\%. Entre 1800-1848, empréstimos foram indicados em 17 (85,0\%) inventários; o recebimento de dinheiro na forma de aluguéis foram praticados por três $(15,0 \%)$ inventariados. De 1849-1888, inventariados que tinham emprestado dinheiro a mais de 
quatro pessoas diferentes somaram 26 (78,8\%); os aluguéis foram indicados em dois (6,1\%) processos; e cinco (15,1\%) inventariados adquiriram ações e apólices.

\section{TABELA 17}

Relação de inventariados escravistas e não escravistas que possuíam apólices, eram credores e complementavam suas rendas com aluguéis de imóveis ou de escravos. Angra dos Reis, 1800-1888

\begin{tabular}{|c|c|c|c|c|c|}
\hline Atividades & $\begin{array}{c}\text { Não } \\
\text { escravistas } \\
\mathrm{n}^{\circ}(\%)\end{array}$ & $\begin{array}{c}1-5 \\
\text { escravos } \\
n^{\circ}(\%)\end{array}$ & $\begin{array}{c}6-10 \\
\text { escravos } \\
n^{\circ}(\%)\end{array}$ & $\begin{array}{c}11-20 \\
\text { escravos } \\
n^{\circ}(\%)\end{array}$ & $\begin{array}{c}21 \text { ou mais } \\
\text { escravos } \\
n^{\circ}(\%)\end{array}$ \\
\hline \multicolumn{6}{|l|}{$1800-1848$} \\
\hline Empréstimos & $1(100,0)$ & $5(71,4)$ & $2(100,0)$ & $3(75,0)$ & $6(100,0)$ \\
\hline Aluguéis & 0 & $2(28,6)$ & 0 & $1(25,0)$ & 0 \\
\hline Ações e apólices & 0 & 0 & 0 & 0 & 0 \\
\hline Total & $1(100,0)$ & $7(100,0)$ & $2(100,0)$ & $4(100,0)$ & $6(100,0)$ \\
\hline \multicolumn{6}{|l|}{ 1849-1888 } \\
\hline Empréstimos & $3(75,0)$ & $10(76,9)$ & $5(100,0)$ & $2(66,7)$ & $6(75,0)$ \\
\hline Aluguéis & 0 & $1(7,7)$ & 0 & $1(33,3)$ & 0 \\
\hline Ações e apólices & $1(25,0)$ & $2(15,4)$ & 0 & 0 & $2(25,0)$ \\
\hline Total & $4(100,0)$ & $13(100,0)$ & $5(100,0)$ & $3(100,0)$ & $8(100,0)$ \\
\hline
\end{tabular}

FONTES: Inventários post-mortem de Angra dos Reis, 1800-1888. Museu da Justiça do Estado do Rio de Janeiro, RJ.

Nos anos de 1800 a 1848, os empréstimos eram concedidos por não escravistas, pequenos escravistas, médios e, principalmente, grandes. Dos escravistas com até cinco cativos, dois viviam apenas de empréstimos. Os demais credores, independentemente da faixa de tamanho de propriedade, conjugavam a prática do empréstimo com cobrança de juros, e a agricultura. Já os aluguéis referiam-se à locação de casas.

Nos anos entre 1849 e 1888, o empréstimo foi concedido por escravistas e não escravistas. Em seis inventários, sendo dois de não escravistas, três de proprietários de um a cinco cativos, e um com seis a 10 escravos, houve apenas referência à concessão de dinheiro a outrem. Os demais credores eram também agricultores, obtinham seus alimentos por meio da pesca e produziam aguardente. O recebimento de aluguéis resultaram de aluguéis de escravos e de casas. E a obtenção de ações e apólices foi realizada por não escravistas e donos de 1-5 escravos e de 21 ou mais cativos.

Portanto, observamos que, com a chegada da segunda metade dos oitocentos, houve um maior interesse pela obtenção de ações e apólices da dívida pública. 
No ano de 1880, Cândida Moreira de Paiva deu início ao inventário de seu finado marido, João de Alvarenga Rocha ${ }^{84}$. Ele era comerciante com loja estabelecida na freguesia da Conceição, além de possuir uma casa assobradada "em perfeito estado". Não tinha escravos, mas objetos de casa, mercadorias da loja e prata. Entretanto, 74,0\%, ou trinta e um contos, noventa e cinco mil e cento e oitenta réis (31:095\$180), de todo seu patrimônio estava aplicado em dívidas ativas, ações e apólices.

João de Alvarenga Rocha era credor da firma comercial Barbosa \& Guimarães e Cia, localizada no Rio de Janeiro. Detinha, ainda, 15 apólices da dívida pública, 10 ações do Banco Mercantil, 40 ações do Banco Nacional,15 ações da Companhia das Minas de Ouro e Cobre do Sul do Brasil e um título da Companhia da Estrada de Ferro de MacaéCampos.

O inventariado acima foi um dos indivíduos que, após 1850, começou a investir em apólices, substituindo a aplicação em terras e escravos ${ }^{85}$.

Os homens mais enriquecidos de Angra, além de terem consciência que a escravidão não demoraria muito para acabar, não contavam mais com a promissora atividade comercial vinculada ao escoamento do café. Como conseqüência, quem pôde, investiu em ações e apólices. Entretanto, esta não foi a realidade de grande parte da população angrense.

\footnotetext{
${ }^{84}$ Inventário de João de Alvarenga Rocha, 1880. Angra dos Reis, RJ. Museu da Justiça do Estado do Rio de Janeiro, RJ.

${ }^{85}$ Fragoso \& Rios (1995) analisaram a trajetória de um dos homens mais ricos da última década do Império, o Comendador Manoel de Aguiar Vallim, residente em Bananal, no vale do Paraíba paulista. Até meados do século XIX, era um típico empresário rural, vivendo de empréstimos a juros altos e da falência de terceiros. Todo o patrimônio adquirido era investido na compra de terras e de escravos, correspondendo a $80 \%$ dos seus bens, até meados de 1860 . Entretanto, ao longo da segunda metade do século XIX, tanto Vallim quanto outros, deixaram de comprar escravos e terras e passaram a investir em ações não agrícolas (FRAGOSO \& RIOS, 1995, p. 199).
} 
TABELA 18

Cultivos indicados nos inventários de Angra dos Reis, entre os anos de 1800 e 1888

\begin{tabular}{c|ccc|c|c|c|c|c}
\hline Agricultura & $\begin{array}{c}1800-1815 \\
\mathrm{n}^{\circ}(\%)\end{array}$ & $\begin{array}{c}1816-1826 \\
\mathrm{n}^{\circ}(\%)\end{array}$ & $\begin{array}{c}1827-1837 \\
\mathrm{n}^{\circ}(\%)\end{array}$ & $\begin{array}{c}1838-1848 \\
\mathrm{n}^{\circ}(\%)\end{array}$ & $\begin{array}{c}1849-1859 \\
\mathrm{n}^{\circ}(\%)\end{array}$ & $\begin{array}{c}1860-1871 \\
\mathrm{n}^{\circ}(\%)\end{array}$ & $\begin{array}{c}1872-1888 \\
\mathrm{n}^{\circ}(\%)\end{array}$ & $\begin{array}{c}\text { Total } \\
\mathrm{n}^{\circ}(\%)\end{array}$ \\
\hline Subsistência \\
Arroz & 0 & 0 & $1(2,3)$ & $2(3,5)$ & $2(3,8)$ & $2(1,9)$ & 0 & $7(2,3)$ \\
Feijão & 0 & 0 & $2(4,5)$ & $1(1,7)$ & $3(5,7)$ & $3(2,9)$ & 0 & $9(2,9)$ \\
Milho & 0 & 0 & $1(2,3)$ & $1(1,7)$ & $4(7,5)$ & $3(2,9)$ & 0 & $9(2,9)$ \\
Laranjeiras & 0 & $1(6,6)$ & $5(11,4)$ & $6(10,5)$ & $4(7,5)$ & $10(9,8)$ & 0 & $26(8,6)$ \\
Coqueiros da Bahia & 0 & 0 & $3(6,8)$ & $3(5,3)$ & $3(5,7)$ & $9(8,9)$ & $4(14,3)$ & $22(7,3)$ \\
Bananeiras & 0 & 0 & $1(2,3)$ & 0 & $2(3,8)$ & $7(6,9)$ & 0 & $10(3,3)$ \\
Jabuticabeiras & 0 & 0 & 0 & $1(1,7)$ & 0 & $4(3,9)$ & $1(3,6)$ & $6(1,9)$ \\
Frutos em geral & 0 & 0 & 0 & 0 & 0 & $4(3,9)$ & 0 & $4(1,4)$ \\
St & 0 & $1(6,6)$ & $13(29,5)$ & $14(24,6)$ & $18(33,9)$ & $42(41,2)$ & $5(17,9)$ & $93(30,8)$ \\
\hline Mercado & \multicolumn{7}{c}{0} \\
Café & $1(33,3)$ & $6(40,0)$ & $17(38,6)$ & $25(43,8)$ & $19(35,8)$ & $31(30,4)$ & $15(53,6)$ & $114(37,7)$ \\
Cana & $1(33,3)$ & $3(20,0)$ & $2(4,5)$ & $4(7,0)$ & $3(5,7)$ & $5(4,9)$ & $6(21,4)$ & $24(7,9)$ \\
Mandioca & $1(33,3)$ & $5(33,3)$ & $12(27,3)$ & $13(22,8)$ & $12(22,6)$ & $24(23,5)$ & 0 & $67(22,2)$ \\
St & $3(100,0)$ & $14(93,4)$ & $31(70,5)$ & $42(73,7)$ & $34(64,1)$ & $60(58,8)$ & $21(75,0)$ & $205(67,9)$ \\
\hline Outros & 0 & 0 & 0 & $1(1,7)$ & $1(1,9)$ & 0 & $2(7,1)$ & $4(1,4)$ \\
\hline Total & $3(100,0)$ & $15(100,0)$ & $44(100,0)$ & $57(100,0)$ & $53(100,0)$ & $102(100,0)$ & $28(100,0)$ & $302(100,0)$ \\
\hline
\end{tabular}

FONTES: Inventários post-mortem de Angra dos Reis, 1800-1888. Museu da Justiça do Estado do Rio de Janeiro, RJ. NOTAS: St=subtotal. Outros cultivos=algodão e fumo.

Dos inventários com avaliação de plantações, os cafezais foram os mais freqüentes, citados em 37,7\% dos processos. Como resultado, 67,9\% possuíam vinculação com a venda de cultivos para o mercado. A segunda cultura mais indicada foi a da mandioca, presente em 22,2\% das propriedades. Não obstante, 30,8\% das culturas eram destinadas à subsistência ${ }^{86}$.

Por ocasião do inventário de Manoel Alves de Campos, em 1834, sua viúva Ana Joaquina de Jesus apresentou aos avaliadores, dentre os demais itens do patrimônio do casal, 355 braças de terra de testada na Enseada da Estrela, na Ilha Grande, repletas por cafezais; cana, que daria cinco e meia pipas de aguardente, mandioca, que produziria 646 alqueires de farinha; vários pés de laranjeiras, arroz, feijão preto e coqueiros da Bahia. Todos os cultivos eram cuidados por 51 cativos $^{87}$.

\footnotetext{
${ }^{86}$ Com certeza, a produção para subsistência deveria ser maior do que a freqüência encontrada por nós.

${ }^{87}$ O casal possuía, ainda, casas, paiol, rancho, diversos móveis de casa, roupa, louça, oito canoas, uma rede de arrasto, uma roda de ralar mandioca, ferramentas, semoventes, ouro, prata, pedras preciosas, dinheiro e dívidas ativas. Inventário de Manoel Joaquim de Campos, 1834. Angra dos Reis, RJ. Museu da Justiça do Estado do Rio de Janeiro, RJ.
} 
A família dedicava-se tanto ao cultivo de alimentos para consumo, quanto por itens que seriam vendidos no mercado, como o café e a aguardente.

Mas, ao longo da segunda metade do século XIX, a cafeicultura e, portanto, a produção destinada ao mercado, diminuiu: de 1800-1848, alimentos representaram 23,7\% e a produção para o mercado, 76,3\%. Entre 1849 e 1888, os percentuais foram de 36,1\% e de 63,9\%. O café foi citado em 41,5\% dos processos datados de 1800 até 1848 e 36,1\%, entre 1849 e 1888.

Entre 1800 e 1848, das escravarias com até cinco escravos, 55,2\% possuíam cafeeiros; 45,2\% das propriedades com 6-10 escravos dedicavam-se ao plantio do café; atividade realizada por $38,9 \%$ das escravarias com $11-20$; e $36,1 \%$ das escravarias com 21 ou mais cativos. Ou seja, o envolvimento com a cultura do café diminuía com o aumento da faixa de tamanho de propriedade (FTP). Entretanto, as maiores propriedades destacavam-se pela variedade agrícola, incluindo arroz, feijão e milho.

Nos anos de 1849 até 1888, dois inventariados não escravistas plantavam café, representando 28,6\% dos itens agrícolas indicados nos processos, enquanto $57,1 \%$ dos cultivos referiam-se a frutos. Nas escravarias com 1 a 5 trabalhadores, 44,8\% das plantações eram formadas por cafeeiros; no caso das propriedades com 6-10, 39,3\% possuíam cafeeiros; 47,8\% de inventariados com 11-20 cativos também apontaram a existência da rubiácea; e, finalmente, 30,2\% dos grandes escravistas eram cafeicultores.

Independentemente do intervalo de tempo, em geral, quanto maior a propriedade, maior era a diversidade de cultivos e menor percentual de cafeeiros.

Acompanhando a diminuição do movimento portuário, do quadro de enfraquecimento econômico, os anos da segunda metade dos oitocentos foram marcados pela diminuição do cultivo do café; diga-se, de passagem, rubiácea de qualidade inferior à plantada “serra-acima”.

Portanto, entre a primeira e a segunda metade dos oitocentos, houve a diminuição da participação dos comerciantes/agricultores possuidores de médias e grandes escravarias; a indicação ao café reduziu-se; além do esvaziamento de escravos nas propriedades (Cf. capítulo 2); e do abandono dos portos locais. Após 1850 aumentou a participação de não escravistas dentre os inventariados. E, um novo dado, elevou-se a 
incidência de inventários que tinham $50 \%$ ou mais do patrimônio comprometido com dívidas passivas.

\section{TABELA 19}

Participação das dívidas passivas sobre o patrimônio dos inventariados por faixas de tamanho de propriedades. Angra dos Reis, 1800-1888

\begin{tabular}{|c|c|c|c|c|c|c|}
\hline Dívidas passivas & $\begin{array}{c}\text { Não } \\
\text { escravistas }\end{array}$ & $\begin{array}{c}1-5 \\
\text { escravos }\end{array}$ & $\begin{array}{c}\text { 6-10 } \\
\text { escravos }\end{array}$ & $\begin{array}{c}11-20 \\
\text { escravos }\end{array}$ & $\begin{array}{l}21 \text { ou mais } \\
\text { escravos }\end{array}$ & Total \\
\hline \multicolumn{7}{|l|}{$1800-1848$} \\
\hline 50 a $60 \%$ do patrimônio & 0 & 1 & 0 & 0 & 0 & 1 \\
\hline 61 a 70\% do patrimônio & 0 & 0 & 1 & 0 & 0 & 1 \\
\hline 71 a $80 \%$ do patrimônio & 0 & 0 & 0 & 1 & 0 & 1 \\
\hline 81 a $90 \%$ do patrimônio & 0 & 0 & 0 & 0 & 0 & 0 \\
\hline 91 a $100 \%$ do patrimônio & 0 & 0 & 0 & 0 & 0 & 0 \\
\hline $\begin{array}{l}\text { Patrimônio menor que as } \\
\text { dívidas passivas }\end{array}$ & 0 & 2 & 0 & 0 & 1 & 3 \\
\hline Total & 0 & 3 & 1 & 1 & 1 & 6 \\
\hline \multicolumn{7}{|l|}{$1849-1888$} \\
\hline 50 a $60 \%$ do patrimônio & 1 & 3 & 1 & 0 & 0 & 5 \\
\hline 61 a $70 \%$ do patrimônio & 0 & 2 & 2 & 0 & 0 & 4 \\
\hline 71 a $80 \%$ do patrimônio & 0 & 1 & 1 & 0 & 0 & 2 \\
\hline 81 a 90\% do patrimônio & 0 & 1 & 0 & 0 & 1 & 2 \\
\hline 91 a 100\% do patrimônio & 2 & 0 & 0 & 0 & 0 & 2 \\
\hline $\begin{array}{c}\text { Patrimônio menor que as } \\
\text { dívidas passivas }\end{array}$ & 3 & 5 & 1 & 1 & 0 & 10 \\
\hline Total & 6 & 12 & 5 & 1 & 1 & 25 \\
\hline
\end{tabular}

FONTES: Inventários post-mortem de Angra dos Reis, 1800-1888. Museu da Justiça do Estado do Rio de Janeiro, RJ.

Nos anos anteriores a 1849, seis inventários estavam com mais da metade do patrimônio comprometido com o pagamento de dívidas, destacando-se os processos pertencentes aos pequenos escravistas. Entre 1849 e 1888 encontramos 25 inventariados com dívidas passivas elevadas, destacando-se 10 processos nos quais os bens tiveram que ser arrematados para o pagamento dos credores. Nestes anos houve intensa participação de não escravistas e de pequenos proprietários endividados.

De todos os 91 inventariados (escravistas e não escravistas), da primeira metade do século, 6,6\% estavam em situação econômica desfavorável. No entanto, o percentual elevou-se para 15,7\% (de 159 processos), após 1849.

Francisco Xavier Simões, morador na Enseada da Estrela, na Ilha Grande, vivia das suas plantações de café e mandioca e da pesca. No ano de 1864, quando foi iniciado o seu inventário, ele tinha sete escravos. No entanto, 76,3\% do seu patrimônio estava 
comprometido com dívidas passivas ${ }^{88}$. Dona Maria Antônia de Jesus, inventariante dos bens de seu marido, Manoel Pedro da Silva, encontrava-se em situação mais complicada no ano de 1874. Ela, moradora em Palmas, na Ilha Grande, viu seu único escravo, Caetano crioulo, de 24 anos, ser arrematado para pagamento das dívidas passivas, calculadas em 83,4\% dos bens do casal ${ }^{89}$. Em 1880, os herdeiros dos bens de João Corrêa da Cruz, lavrador e morador na Parnaioca, também na Ilha Grande, não tiveram como arcar com uma dívida, "por capital e juros emprestado" de um conto, oitocentos e quarenta e cinco mil e cento e noventa e seis réis (1:845\$196), assumida pelo inventariado com o negociante e morador de Angra dos Reis, Major Antônio José da Silva $^{90}$. O patrimônio de João Corrêa da Cruz não chegava a 600 mil réis.

Finalmente, com base na análise dos inventários, constatamos que a agricultura era a base da vida econômica local, em particular, as culturas do café e da mandioca. No entanto, na primeira metade do século, o comércio apareceu associado a alguns dos maiores patrimônios, medido em números de escravos. Estes comerciantes possivelmente se beneficiaram do intenso movimento portuário, estando, inclusive, vinculados ao transporte da rubiácea vinda da "serra acima” até o Rio de Janeiro. Porém, após os anos de 1850, houve a redução da atividade portuária, diminuição do cultivo do café e do número de escravos. A freqüência de inventários sem escravos elevou-se, assim como os patrimônios comprometidos com dívidas passivas acima de 50\% do valor dos bens.

O típico escravista de Angra dos Reis era senhor de poucos escravos. Esse foi o perfil mais comum de propriedade, tanto na primeira quanto na segunda metade do século XIX.

E os escravos? Qual a experiência mais comum? Viver em grandes propriedades ou compartilhar o dia-a-dia diretamente com homens livres, em escravarias reduzidas?

\footnotetext{
${ }^{88}$ Inventário de Francisco Xavier Simões, 1864. Angra dos Reis, RJ. Museu da Justiça do Estado do Rio de Janeiro, RJ.

${ }^{89}$ Inventário de Manoel Pedro da Silva, 1874. Angra dos Reis, RJ. Museu da Justiça do Estado do Rio de Janeiro, RJ.

${ }^{90}$ Inventário de João Corrêa da Cruz, 1880. Angra dos Reis, RJ. Museu da Justiça do Estado do Rio de Janeiro, RJ.
} 
TABELA 20

Número de escravos por faixas de tamanho de propriedades e por subperíodos. Angra dos Reis, 1800-1888

\begin{tabular}{c|c|c|c|c|c|c|c|c}
\hline FTP & $\begin{array}{c}1800-1815 \\
\mathrm{n}^{\circ}(\%)\end{array}$ & $\begin{array}{c}1816-1826 \\
\mathrm{n}^{\circ}(\%)\end{array}$ & $\begin{array}{c}1827-1837 \\
\mathrm{n}^{\circ}(\%)\end{array}$ & $\begin{array}{c}1838-1848 \\
\mathrm{n}^{\circ}(\%)\end{array}$ & $\begin{array}{c}1849-1859 \\
\mathrm{n}^{\circ}(\%)\end{array}$ & $\begin{array}{c}1860-1871 \\
\mathrm{n}^{\circ}(\%)\end{array}$ & $\begin{array}{c}1872-1888 \\
\mathrm{n}^{\circ}(\%)\end{array}$ & $\begin{array}{c}\text { Total } \\
\mathrm{n}^{\circ}(\%)\end{array}$ \\
\hline $1-5$ & $6(26,1)$ & $12(6,6)$ & $38(8,7)$ & $50(10,4)$ & $64(14,4)$ & $91(10,2)$ & $54(20,3)$ & $315(11,6)$ \\
$6-10$ & 0 & $14(7,7)$ & $40(9,2)$ & $73(15,2)$ & $69(15,7)$ & $91(10,2)$ & $31(11,6)$ & $318(11,7)$ \\
$11-20$ & $17(73,9)$ & $56(30,7)$ & $31(7,1)$ & $59(12,3)$ & $40(9,0)$ & $178(20,0)$ & $80(30,1)$ & $461(17,0)$ \\
21 ou mais & 0 & $100(55,0)$ & $326(75,0)$ & $297(62,1)$ & $270(60,9)$ & $530(59,6)$ & $101(38,0)$ & $1.624(59,7)$ \\
Total & $23(100,0)$ & $182(100,0)$ & $435(100,0)$ & $479(100,0)$ & $443(100,0)$ & $890(100,0)$ & $266(100,0)$ & $2.718(100,0)$ \\
\hline
\end{tabular}

FONTES: Inventários post-mortem de escravistas de Angra dos Reis, 1800-1888. Museu da Justiça do Estado do Rio de Janeiro, RJ.

NOTA: FTP=faixa de tamanho de propriedades.

Entre 1800 e 1888 mais de 50\% dos cativos pertenciam a escravarias com 21 ou mais trabalhadores compulsórios.

A característica aqui apresentada, assim como as faixas de tamanho de propriedades, confirma os dados encontrados para outras localidades. Alguns exemplos: no ano de 1817, em Areias, 34,9\% dos escravos pertenciam a senhores com 21 ou mais cativos. Em 1822, o percentual chegou a 45,2\%; 52,1\%, em 1829; e, em 1836, 47,1\% da escravaria de Areias vivia nas grandes propriedades (LUNA, 1995, p. 10). Em Bananal, dos escravos existentes, 50,6\%, 47,3\% e 62,2\%, respectivamente, nos anos de 1801, 1817 e de 1829 trabalhavam nas propriedades com 20 ou mais cativos (MOTTA, 1999a, p. 168).

Observamos nos dados da tabela 20, a evolução dos escravos nas diferentes faixas de tamanho de propriedade. Não se levando em conta o primeiro subperíodo (18001815), devido ao pequeno número de inventários, verificamos o aumento da presença de escravos em grandes propriedades. De 1816-1826 até 1827-1837, a participação daqueles passou de 55\% para 75\%. No último subperíodo, quase todos os cativos avaliados estavam em grandes escravarias. De 1838 até 1871, o percentual girou em torno de 50\%. No entanto, entre 1872 e 1888, apenas 38,0\% dos cativos pertenciam a grandes senhores $^{91}$.

\footnotetext{
${ }^{91}$ As médias de escravos nos subperíodos foram de: 4,6; 12;1; 14,0; 12,9; 9,8;14,4; e 8,1; respectivamente, entre 1800-1815, 1816-1826, 1827-1837, 1838-1848, 1849-1859, 1860-1871 e 1872-1888.
} 
Isto é, nos anos mais favoráveis economicamente, um determinado grupo de homens livres encontrou possibilidades de acumular mão-de-obra. Com o passar da segunda parte dos oitocentos, a diminuição do número de escravos, em todo o município, se fez sentir também nas grandes propriedades.

Nos anos entre 1800 e 1848, 9,5\% dos escravos estavam nas pequenas propriedades; 25,9\%, nas médias (6-20 cativos); e 64,6\%, nas grandes. Portanto, foi um período de concentração de cativos em poucas mãos. Entre 1849 e 1888, a participação de trabalhadores nas pequenas escravarias chegou a 13,1\%; nas médias estavam 30,5\% dos escravos avaliados; e nas grandes, 56,4\%. Nesses anos, aumentou a freqüência de escravos em pequenas e médias propriedades. Isso ocorreu não porque o acesso aos cativos tenha se tornado mais fácil, pelo contrário, a possibilidade de aquisição dos mesmos tornou-se mais difícil ${ }^{92}$. Assim sendo, a probabilidade de acumular cativos diminuiu. A tendência, possivelmente, foi a transformação de médias propriedades, em pequenas, e grandes, em médias. Entretanto, na segunda metade dos oitocentos, 50\% dos cativos anotados pelos avaliadores pertenciam aos grandes senhores.

Os percentuais de trabalhadores nas maiores escravarias, independentemente dos dois subperíodos, foram mais representativos nas faixas de tamanho de propriedades com 21 ou mais cativos.

As freqüências ultrapassaram alguns números calculados por outros pesquisadores. Dentre eles, Godoy (1992, p. 75) localizou 41,3\%, em 1832, e 31,7\%, em 1839, de escravos nas mãos dos senhores com 21 ou mais trabalhadores compulsórios, em Bocaiúva, no norte de Minas. Costa \& Nozoe (1989, p. 327), estudando Lorena, no vale do Paraíba paulista, no ano de 1801, chegaram a 30,0\% de escravos nas propriedades com 16 a 41 cativos.

A diante, alguns dos informes demográficos encontrados nos inventários serão apresentados, contribuindo para complementar as conclusões obtidas no capítulo 2.

\footnotetext{
${ }^{92}$ Vale a pena recordar que a representatividade de escravos no município diminuiu: em 1840 havia 46,7\% de cativos, sobre o total da população de Angra; no ano de 1850, 41,6\%; em 1856, 36,8\%; e em 1872, 20,8\% (cf. capítulo 2).
} 
TABELA 21

Razão de sexo dos escravos inventariados por subperíodos. Angra dos Reis, 1800-1888

\begin{tabular}{c|c|c|c|c|c|c|c|c}
\hline Subperíodos & $1800-1815$ & $1816-1826$ & $1827-1837$ & $1838-1848$ & $1849-1859$ & $1860-1871$ & $1872-1888$ & Total \\
\hline $\begin{array}{c}\text { Razão de } \\
\text { sexo }\end{array}$ & 175 & 130 & 98 & 120 & 97 & 122 & 110 & 113 \\
\hline
\end{tabular}

FONTES: Inventários post-mortem de escravistas de Angra dos Reis, 1800-1888. Museu da Justiça do Estado do Rio de Janeiro, RJ.

Excluindo os anos de 1800 a 1815, quando havia 175 homens para cada 100 mulheres, e de 1816 a 1826, quando a razão de sexo foi de 130, nos demais, podemos dizer que houve uma tendência ao equilíbrio numérico entre homens e mulheres.

Portanto, como foi visto no capítulo 2, a população escrava masculina não possuía grande representatividade, assim como houve uma tendência ao equilíbrio entre os sexos, favorecendo, conseqüentemente, a possibilidade de reprodução interna. Observamos isso mais claramente quando dividimos os dados para a primeira e a segunda metade dos oitocentos: entre 1800 e 1848, a razão encontrada foi de 115 e, entre 1849 a 1888, de 113.

\section{TABELA 22}

Razão de sexo dos escravos inventariados por faixas de tamanho de propriedades e por subperíodos. Angra dos Reis, 1800-1888

\begin{tabular}{ccc|c|c|c|c|c|c}
\hline FTP & $1800-1815$ & $1816-1826$ & $1827-1837$ & $1838-1848$ & $1849-1859$ & $1860-1871$ & $1872-1888$ & Total \\
\hline $\begin{array}{c}1-5 \\
\text { Razão de sexo }\end{array}$ & 200 & 100 & 75 & 108 & 90 & 127 & 150 \\
\hline $\begin{array}{c}6-10 \\
\text { Razão de sexo }\end{array}$ & 0 & 366 & 120 & 132 & 74 & 93 & 107 \\
\hline $\begin{array}{c}11-20 \\
\text { Razão de sexo }\end{array}$ & 166 & 107 & 106 & 145 & 53 & 91 & 92 \\
\hline $\begin{array}{c}21 \text { ou mais } \\
\text { Razão de sexo }\end{array}$ & 0 & 133 & 98 & 115 & 118 & 141 & 98 \\
\hline
\end{tabular}

FONTES: Inventários post-mortem de escravistas de Angra dos Reis, 1800-1888. Museu da Justiça do Estado do Rio de Janeiro, RJ.

NOTA: FTP=faixa de tamanho de propriedades.

Quando comparamos as faixas de tamanho de propriedades, entre 1800 e 1888, observamos a maior discrepância na freqüência entre homens e mulheres nas maiores propriedades, com razão de sexo de 120. Este número é aceitável, já que foram os senhores mais enriquecidos que tiveram mais acesso aos escravos do sexo masculino, dado o maior valor que era cobrado por eles no mercado. 
No entanto, excluindo algumas razões de sexo elevadas como, entre 1800-1815, e de 1872-1888, na FTP de 1-5; nos anos de 1816-1826, quando a razão foi de 366, na FTP de 6-10; e 145, nas propriedades de 11-20 cativos; podemos afirmar que, praticamente os escravos das diferentes FTP não conheceram grande diferença numérica, entre homens e mulheres.

\section{TABELA 23}

Faixa etária dos escravos por subperíodos. Angra dos Reis, entre 1800 e 1888

\begin{tabular}{c|c|c|c|c|c|c|c|c}
\hline Idades & $\begin{array}{c}1800-1815 \\
n^{\circ}(\%)\end{array}$ & $\begin{array}{c}1816-1826 \\
n^{\circ}(\%)\end{array}$ & $\begin{array}{c}1827-1837 \\
n^{\circ}(\%)\end{array}$ & $\begin{array}{c}1838-1848 \\
n^{\circ}(\%)\end{array}$ & $\begin{array}{c}1849-1859 \\
n^{\circ}(\%)\end{array}$ & $\begin{array}{c}1860-1871 \\
n^{\circ}(\%)\end{array}$ & $\begin{array}{c}1872-1888 \\
n^{\circ}(\%)\end{array}$ & $\begin{array}{c}\text { Total } \\
n^{\circ}(\%)\end{array}$ \\
\hline 0-7 anos & $5(22,7)$ & $28(15,5)$ & $80(18,8)$ & $89(18,9)$ & $70(17,7)$ & $163(18,7)$ & $26(10,6)$ \\
$461(17,7)$ \\
8-14 anos & $5(22,7)$ & $31(17,2)$ & $46(10,8)$ & $56(11,9)$ & $60(15,2)$ & $109(12,5)$ & $39(16,0)$ & $346(13,3)$ \\
$15-40$ anos & $4(18,2)$ & $91(50,6)$ & $243(57,2)$ & $227(48,3)$ & $197(49,7)$ & $381(43,6)$ & $117(48,0)$ & $1.260(48,3)$ \\
41 ou mais & $8(36,4)$ & $30(16,7)$ & $56(13,2)$ & $98(20,9)$ & $69(17,4)$ & $220(25,2)$ & $62(25,4)$ & $543(20,7)$ \\
Total & $22(100,0)$ & $180(100,0)$ & $425(100,0)$ & $470(100,0)$ & $396(100,0)$ & $873(100,0)$ & $244(100,0)$ & $2.610(100,0)$ \\
\hline
\end{tabular}

FONTES: Inventários post-mortem de escravistas de Angra dos Reis, 1800-1888. Museu da Justiça do Estado do Rio de Janeiro, RJ.

NOTA: Ficaram de fora da contagem 108 escravos, pois suas idades não foram indicadas.

A maior parte dos escravos avaliados eram adultos, representando 48,3\%. As crianças corresponderam a 31,0\% e os idosos, 20,7\%. O mesmo perfil etário foi encontrado para todos os subperíodos. Ou seja, além do ligeiro predomínio de homens entre os cativos, os escravos adultos representaram a maioria, seguidos pelas crianças e pelos idosos. No entanto, organizando o material a partir dos dois grandes recortes temporais, 1800-1848 e 1849-1888, observamos: no primeiro subperíodo, 51,5\% dos escravos eram adultos, 31,0\% eram crianças e 17,5\%, idosos; no segundo subperíodo, os percentuais foram de, respectivamente, 45,9\%, 30,8\% e 23,2\%.

Ao longo dos anos, os adultos continuaram sendo o perfil mais comum de escravos avaliados, entretanto, a participação de idosos aumentou ao longo da segunda metade do século XIX. Essa tendência também já tinha sido vista no capítulo 2 e resultou do envelhecimento dos trabalhadores, pois sem o tráfico de escravos, a partir de 1850 , os senhores contaram, principalmente, com a reprodução interna ${ }^{93}$.

\footnotetext{
${ }^{93}$ É bem verdade que o tráfico interno garantiu a reposição de mão-de-obra em várias áreas do centro sul do Brasil, mas em Angra, por certo, a reposição era feita pelos nascimentos de novos cativos.
} 
TABELA 24

Idade dos escravos por faixas de tamanho de propriedades e por subperíodos. Angra dos Reis, 1800-1888

\begin{tabular}{|c|c|c|c|c|c|c|c|c|}
\hline FTP & $\begin{array}{c}1800-1815 \\
\mathrm{n}^{\circ}(\%) \\
\end{array}$ & $\begin{array}{c}1816-1826 \\
\mathrm{n}^{\mathrm{o}}(\%) \\
\end{array}$ & $\begin{array}{c}1827-1837 \\
\mathrm{n}^{\circ}(\%)\end{array}$ & $\begin{array}{c}1838-1848 \\
\mathrm{n}^{\circ}(\%) \\
\end{array}$ & $\begin{array}{c}1849-1859 \\
\mathrm{n}^{\circ}(\%)\end{array}$ & $\begin{array}{c}1860-1871 \\
\mathrm{n}^{\circ}(\%)\end{array}$ & $\begin{array}{c}1872-1888 \\
\mathrm{n}^{\circ}(\%) \\
\end{array}$ & $\begin{array}{c}\text { Total } \\
\mathrm{n}^{\circ}(\%) \\
\end{array}$ \\
\hline \multicolumn{9}{|l|}{$1-5$} \\
\hline 0-7 anos & $1(16,6)$ & 0 & $5(14,3)$ & $7(14,6)$ & $9(14,7)$ & $14(17,1)$ & $2(4,0)$ & $38(12,9)$ \\
\hline 8-14 anos & $3(50,0)$ & $2(16,7)$ & $4(11,4)$ & $3(6,3)$ & $6(9,8)$ & $8(9,7)$ & $6(12,0)$ & $32(10,9)$ \\
\hline $15-40$ anos & $1(16,6)$ & $6(50,0)$ & $22(62,8)$ & $21(43,7)$ & $33(54,1)$ & $39(47,6)$ & $27(54,0)$ & $149(50,7)$ \\
\hline 41 ou mais & $1(16,6)$ & $4(33,3)$ & $4(11,4)$ & $17(35,4)$ & $13(21,3)$ & $21(25,6)$ & $15(30,0)$ & $75(25,5)$ \\
\hline St & $6(100,0)$ & $12(100,0)$ & $35(100,0)$ & $48(100,0)$ & $61(100,0)$ & $82(100,0)$ & $50(100,0)$ & $294(100,0)$ \\
\hline \multicolumn{9}{|l|}{$6-10$} \\
\hline 0-7 anos & 0 & $1(7,1)$ & $5(15,2)$ & $13(18,1)$ & $14(20,6)$ & $20(22,5)$ & $4(14,8)$ & $57(18,8)$ \\
\hline 8-14 anos & 0 & $5(35,7)$ & $4(12,1)$ & $7(9,7)$ & $8(11,8)$ & $13(14,6)$ & $6(22,2)$ & $43(14,2)$ \\
\hline $15-40$ anos & 0 & $7(50,0)$ & $17(51,5)$ & $45(62,5)$ & $38(55,8)$ & $39(43,8)$ & $14(51,8)$ & $160(52,8)$ \\
\hline 41 ou mais & 0 & $1(7,1)$ & $7(21,2)$ & $7(9,7)$ & $8(11,8)$ & $17(19,1)$ & $3(11,2)$ & $43(14,2)$ \\
\hline St & 0 & $14(100,0)$ & $33(100,0)$ & $72(100,0)$ & $68(100,0)$ & $89(100,0)$ & $27(100,0)$ & $303(100,0)$ \\
\hline \multicolumn{9}{|l|}{$11-20$} \\
\hline 0-7 anos & $4(25,0)$ & $9(16,1)$ & $6(19,3)$ & $16(27,1)$ & $10(25,0)$ & $48(27,6)$ & $10(13,0)$ & $103(22,7)$ \\
\hline 8-14 anos & $2(12,5)$ & $9(16,1)$ & $4(12,9)$ & $10(16,9)$ & $6(15,0)$ & $28(16,1)$ & $15(19,5)$ & $74(16,3)$ \\
\hline $15-40$ anos & $3(18,8)$ & $28(50,0)$ & $13(41,9)$ & $26(44,1)$ & $14(35,0)$ & $70(40,2)$ & $28(36,4)$ & $182(40,2)$ \\
\hline 41 ou mais & $7(43,7)$ & $10(17,8)$ & $8(25,8)$ & $7(11,8)$ & $10(25,0)$ & $28(16,1)$ & $24(31,1)$ & $94(20,8)$ \\
\hline St & $16(100,0)$ & $56(100,0)$ & $31(100,0)$ & $59(100,0)$ & $40(100,0)$ & $174(100,0)$ & $77(100,0)$ & $453(100,0)$ \\
\hline \multicolumn{9}{|l|}{21 ou mais } \\
\hline 0-7 anos & 0 & $18(18,4)$ & $64(19,6)$ & $53(18,2)$ & $37(16,3)$ & $81(15,3)$ & $10(11,1)$ & $263(16,9)$ \\
\hline 8-14 anos & 0 & $15(15,3)$ & $34(10,4)$ & $36(12,3)$ & $40(17,6)$ & $60(11,4)$ & $12(13,3)$ & $197(12,6)$ \\
\hline $15-40$ anos & 0 & $50(51,0)$ & $191(58,6)$ & $135(46,4)$ & $112(49,3)$ & $233(44,1)$ & $48(53,4)$ & $769(49,3)$ \\
\hline 41 ou mais & 0 & $15(15,3)$ & $37(11,3)$ & $67(23,0)$ & $38(16,7)$ & $154(29,2)$ & $20(22,3)$ & $331(21,2)$ \\
\hline St & 0 & $98(100,0)$ & $326(100,0)$ & $291(100,0)$ & $227(100,0)$ & $528(100,0)$ & $90(100,0)$ & $1.560(100,0)$ \\
\hline
\end{tabular}

FONTES: Inventários post-mortem de escravistas de Angra dos Reis, 1800-1888. Museu da Justiça do Estado do Rio de Janeiro, RJ.

NOTA: St=subtotal.

Em todas as FTP, de 1800-1888, os adultos sempre foram mais freqüentes, particularmente naquelas caracterizadas por 1-5 e por 21 ou mais escravos. Enquanto isso, houve maior participação de crianças nas faixas de 11-20 e de 6-10 cativos. As duas últimas FTP foram aquelas onde as razões de sexo foram menores, respectivamente, 98 e 106. Ou seja, escravarias onde o equilíbrio entre os sexos garantiu a reprodução interna. Entretanto, as propriedades que tinham maior número de adultos, possuíam as “maiores” razões de sexo, as FTP de 1-5, com 111, e de 21 ou mais escravos, com razão de sexo de 120. 
TABELA 25

Origem dos escravos por faixas de tamanho de propriedades e por subperíodos.

Angra dos Reis, 1800-1888

\begin{tabular}{|c|c|c|c|c|c|c|c|c|}
\hline FTP & $\begin{array}{c}1800-1815 \\
\mathrm{n}^{\circ}(\%)\end{array}$ & $\begin{array}{c}1816-1826 \\
n^{\circ}(\%)\end{array}$ & $\begin{array}{c}1827-1837 \\
\mathrm{n}^{\circ}(\%) \\
\end{array}$ & $\begin{array}{c}1838-1848 \\
\mathrm{n}^{\circ}(\%)\end{array}$ & $\begin{array}{c}1849-1859 \\
\mathrm{n}^{\circ}(\%)\end{array}$ & $\begin{array}{c}1860-1871 \\
\mathrm{n}^{\circ}(\%) \\
\end{array}$ & $\begin{array}{c}1872-1888 \\
\mathrm{n}^{\circ}(\%) \\
\end{array}$ & $\begin{array}{c}\text { Total } \\
\mathrm{n}^{\circ}(\%)\end{array}$ \\
\hline \multicolumn{9}{|l|}{$1-5$} \\
\hline Africanos & $4(66,7)$ & $5(83,4)$ & $16(53,4)$ & $18(40,9)$ & $26(49,1)$ & $31(41,3)$ & $7(17,5)$ & $107(42,1)$ \\
\hline Crioulos & $2(33,3)$ & $1(16,6)$ & $14(46,6)$ & $26(59,1)$ & $27(50,9)$ & $44(58,7)$ & $33(82,5)$ & $147(57,9)$ \\
\hline St & $6(100,0)$ & $6(100,0)$ & $30(100,0)$ & $44(100,0)$ & $53(100,0)$ & $75(100,0)$ & $40(100,0)$ & $254(100,0)$ \\
\hline \multicolumn{9}{|l|}{$6-10$} \\
\hline Africanos & 0 & $12(85,7)$ & $16(48,5)$ & $36(52,2)$ & $25(39,1)$ & $19(24,4)$ & 0 & $108(37,5)$ \\
\hline Crioulos & 0 & $2(14,3)$ & $17(51,5)$ & $33(47,8)$ & $39(60,9)$ & $59(75,6)$ & $30(100,0)$ & $180(62,5)$ \\
\hline St & 0 & $14(100,0)$ & $33(100,0)$ & $51(100,0)$ & $64(100,0)$ & $78(100,0)$ & $30(100,0)$ & $288(100,0)$ \\
\hline \multicolumn{9}{|l|}{$11-20$} \\
\hline Africanos & $8(50,0)$ & $17(35,4)$ & $13(44,8)$ & $18(35,3)$ & $9(25,0)$ & $34(20,5)$ & $18(22,5)$ & $117(27,5)$ \\
\hline Crioulos & $8(50,0)$ & $31(64,6)$ & $16(55,2)$ & $33(64,7)$ & $27(75,0)$ & $132(79,5)$ & $62(77,5)$ & $309(72,5)$ \\
\hline St & $16(100,0)$ & $48(100,0)$ & $29(100,0)$ & $51(100,0)$ & $36(100,0)$ & $166(100,0)$ & $80(100,0)$ & $426(100,0)$ \\
\hline \multicolumn{9}{|l|}{21 ou mais } \\
\hline Africanos & 0 & $54(59,3)$ & $146(46,3)$ & $98(35,1)$ & $93(35,9)$ & $163(33,4)$ & $18(18,6)$ & $572(37,4)$ \\
\hline Crioulos & 0 & $37(40,6)$ & $169(53,7)$ & $181(64,9)$ & $166(64,1)$ & $325(66,6)$ & $79(81,4)$ & $957(62,6)$ \\
\hline St & 0 & $91(100,0)$ & $315(100,0)$ & $279(100,0)$ & $259(100,0)$ & $488(100,0)$ & $97(100,0)$ & $1.529(100,0)$ \\
\hline \multicolumn{9}{|l|}{ Total } \\
\hline Africanos & $12(54,5)$ & $88(55,3)$ & $191(46,9)$ & $170(38,4)$ & $153(37,1)$ & $247(30,6)$ & $43(17,4)$ & $904(36,2)$ \\
\hline Crioulos & $10(45,5)$ & $71(44,7)$ & $216(53,1)$ & $273(61,6)$ & $259(62,9)$ & $560(69,4)$ & $204(82,6)$ & $1.593(63,8)$ \\
\hline St & $22(100,0)$ & $159(100,0)$ & $407(100,0)$ & $443(100,0)$ & $412(100,0)$ & $807(100,0)$ & $247(100,0)$ & $2.497(100,0)$ \\
\hline
\end{tabular}

FONTES: Inventários post-mortem de escravistas de Angra dos Reis, 1800-1888. Museu da Justiça do Estado do Rio de Janeiro, RJ.

NOTA: St=subtotal.

De 1800 até 1888, os escravos nascidos no Brasil foram predominantes, correspondendo a 63,8\%. Os africanos, por sua vez, chegaram a 36,4\%. Excluindo os dois primeiros subperíodos de 1800-1815 e de 1816-1826, quando o tráfico de africanos influenciou na grande participação de cativos provenientes do outro lado do Atlântico, nos demais intervalos de tempo, os crioulos tornaram-se mais freqüentes, chegando a 82,6\% dos escravos, entre 1872 e 1888.

Fugindo um pouco ao que fora dito, também foram observadas as grandes propriedades. Nelas, a razão de sexo, entre 1800-1888, foi maior, assim como havia mais adultos. No entanto, a representatividade de crioulos chegou a 62,6\%. Evidentemente que os grandes escravistas fizeram uso da reprodução natural a fim de repor seus escravos mortos ou fugidos. Percebemos que eles também obtiveram cativos no mercado local, possivelmente, adquirindo crioulos em idade adulta, daí a 
participação, se comparada às demais FTP, de escravos com 15 a 40 anos. Enfim, estes senhores possuíam capital necessário para comprar escravos.

TABELA 26

Atividades exercidas pelos escravos homens, segundo os inventários, por subperíodos. Angra dos Reis, 1800-1888

\begin{tabular}{|c|c|c|c|c|c|c|c|c|}
\hline Atividades & $\begin{array}{c}1800- \\
1815 \\
n^{\circ}(\%)\end{array}$ & $\begin{array}{c}1816- \\
1826 \\
n^{\circ}(\%)\end{array}$ & $\begin{array}{c}1827- \\
1837 \\
n^{\circ}(\%)\end{array}$ & $\begin{array}{c}1838- \\
1848 \\
n^{\circ}(\%)\end{array}$ & $\begin{array}{c}1849- \\
1859 \\
n^{\circ}(\%)\end{array}$ & $\begin{array}{c}1860- \\
1871 \\
\mathrm{n}^{\circ}(\%)\end{array}$ & $\begin{array}{c}1872- \\
1888 \\
n^{\circ}(\%)\end{array}$ & $\begin{array}{c}\text { Total } \\
\mathrm{n}^{\circ}(\%)\end{array}$ \\
\hline Roça & $1(100,0)$ & $43(97,7)$ & $97(73,5)$ & $130(75,1)$ & $89(78,6)$ & $208(68,2)$ & $48(80,0)$ & $616(74,4)$ \\
\hline Doméstico & & & $2(1,5)$ & $1(0,6)$ & $3(2,8)$ & $6(2,0)$ & $1(1,7)$ & $13(1,6)$ \\
\hline $\begin{array}{l}\text { Pilota canoas ou } \\
\text { remeiro }\end{array}$ & & & $23(17,4)$ & $21(12,1)$ & $9(7,9)$ & $17(5,6)$ & 0 & $70(8,4)$ \\
\hline Pescador & & & 0 & $4(2,3)$ & 0 & $2(0,7)$ & 0 & $6(0,7)$ \\
\hline Carpinteiro & & $1(2,3)$ & $3(2,3)$ & $4(2,3)$ & $3(2,8)$ & $15(5,0)$ & $2(3,3)$ & $28(3,4)$ \\
\hline Marceneiro & & & 0 & 0 & 0 & $3(0,9)$ & 0 & $3(0,5)$ \\
\hline Marinheiro & & & 0 & 0 & $1(0,9)$ & $5(1,6)$ & 0 & $6(0,7)$ \\
\hline Padeiro & & & 0 & 0 & 0 & 0 & $1(1,7)$ & $1(0,1)$ \\
\hline Caixeiro & & & 0 & 0 & 0 & 0 & $1(1,7)$ & $1(0,1)$ \\
\hline Chapeleiro & & & 0 & 0 & 0 & 0 & $1(1,7)$ & $1(0,1)$ \\
\hline Pedreiro & & & 0 & $4(2,3)$ & $2(1,7)$ & $12(3,9)$ & 0 & $18(2,2)$ \\
\hline Sapateiro & & & $4(3,0)$ & $2(1,2)$ & $1(0,9)$ & $1(0,3)$ & 0 & $8(0,9)$ \\
\hline Cabouqueiro & & & 0 & $1(0,6)$ & 0 & 0 & 0 & $1(0,1)$ \\
\hline Ferreiro & & & 0 & $3(1,7)$ & 0 & $13(4,3)$ & 0 & $16(1,9)$ \\
\hline Serrador & & & $1(0,7)$ & 0 & $1(0,9)$ & $1(0,3)$ & 0 & $3(0,5)$ \\
\hline Quitandeiro & & & $1(0,7)$ & 0 & 0 & 0 & 0 & $1(0,1)$ \\
\hline Feitor & & & 0 & 0 & $2(1,7)$ & $1(0,3)$ & $1(1,7)$ & $4(0,5)$ \\
\hline Boleeiro & & & 0 & 0 & 0 & $2(0,7)$ & 0 & $2(0,2)$ \\
\hline Falquejador & & & $1(0,7)$ & 0 & $2(1,7)$ & $5(1,6)$ & 0 & $8(0,9)$ \\
\hline Pastor & & & 0 & $1(0,6)$ & 0 & 0 & 0 & $1(0,1)$ \\
\hline Oleiro & & & 0 & $1(0,6)$ & 0 & 0 & 0 & $1(0,1)$ \\
\hline Canoeiro & & & 0 & 0 & 0 & 0 & $2(3,3)$ & $2(0,2)$ \\
\hline Alambiqueiro & & & 0 & 0 & 0 & 0 & $1(1,7)$ & $1(0,1)$ \\
\hline Cargueiro & & & 0 & 0 & 0 & $3(0,9)$ & $2(3,3)$ & $5(0,6)$ \\
\hline Alfaiate & & & 0 & 0 & 0 & $1(0,3)$ & 0 & $1(0,1)$ \\
\hline Pajé & & & 0 & 0 & 0 & $4(1,3)$ & 0 & $4(0,5)$ \\
\hline Tropeiro & & & 0 & 0 & 0 & $2(0,7)$ & 0 & $2(0,2)$ \\
\hline Cozinheiro & & & 0 & $1(0,6)$ & 0 & $4(1,3)$ & 0 & $5(0,7)$ \\
\hline Total & $1(100,0)$ & $\begin{array}{c}44 \\
(100,0)\end{array}$ & $\begin{array}{c}132 \\
(100,0)\end{array}$ & $\begin{array}{c}173 \\
(100,0)\end{array}$ & $\begin{array}{c}113 \\
(100,0)\end{array}$ & $\begin{array}{c}305 \\
(100,0)\end{array}$ & $\begin{array}{c}60 \\
(100,0)\end{array}$ & $\begin{array}{c}828 \\
(100,0)\end{array}$ \\
\hline
\end{tabular}

FONTES: Inventários post-mortem de escravistas de Angra dos Reis, 1800-1888. Museu da Justiça do Estado do Rio de Janeiro, RJ.

Em todos os subperíodos predominaram os escravos dedicados às atividades agrícolas, daí a representatividade de cativos “de roça”. Isso condiz com a ocupação da maior parte dos senhores, dedicados, na maior parte das vezes, ao cultivo da terra.

Entretanto, na FTP de 21 havia cativos com outras funções (tropeiro, feitor, alambiqueiro, etc.), ou com funções mais especializadas (ofícios de carpinteiro, ferreiro, alfaiate, sapateiro, etc). Estas propriedades, devido ao seu tamanho e às diversas atividades realizadas, requeriam escravos com diferentes aptidões. 
TABELA 27

Atividades exercidas pelos escravos homens, segundo os inventários, por faixas de tamanho de propriedades. Angra dos Reis, 1800-1888

\begin{tabular}{c|c|c|c|c|c}
\hline Atividades & $\begin{array}{c}1-5 \\
\text { escravos } \\
\mathrm{n}^{\circ}(\%)\end{array}$ & $\begin{array}{c}6-10 \\
\text { escravos } \\
\mathrm{n}^{\circ}(\%)\end{array}$ & $\begin{array}{c}11-20 \\
\text { escravos } \\
\mathrm{n}^{\circ}(\%)\end{array}$ & $\begin{array}{c}21 \text { ou mais } \\
\text { escravos } \\
\mathrm{n}^{\circ}(\%)\end{array}$ & $\begin{array}{c}\text { Total } \\
\mathrm{n}^{\circ}(\%)\end{array}$ \\
\hline Roça & $52(72,1)$ & $48(70,6)$ & $79(80,6)$ & $437(74,1)$ & $616(74,4)$ \\
Doméstico & $4(5,6)$ & $3(4,4)$ & $2(2,0)$ & $4(0,7)$ & $13(1,6)$ \\
Pilota canoas ou remeiro & $7(9,7)$ & $8(11,7)$ & $7(7,1)$ & $48(8,1)$ & $70(8,4)$ \\
Pescador & $1(1,4)$ & $2(2,9)$ & $3(3,1)$ & 0 & $6(0,8)$ \\
Carpinteiro & $1(1,4)$ & $1(1,5)$ & $5(5,1)$ & $21(3,6)$ & $28(3,4)$ \\
Marceneiro & 0 & 0 & 0 & $3(0,5)$ & $3(0,5)$ \\
Marinheiro & $2(2,8)$ & $1(1,5)$ & 0 & $3(0,5)$ & $6(0,7)$ \\
Padeiro & $1(1,4)$ & 0 & 0 & 0 & $1(0,1)$ \\
Caixeiro & $1(1,4)$ & 0 & 0 & 0 & $1(0,1)$ \\
Chapeleiro & $1(1,4)$ & 0 & 0 & 0 & $1(0,1)$ \\
Pedreiro & $1(1,4)$ & $1(1,5)$ & 0 & $16(2,7)$ & $18(2,2)$ \\
Sapateiro & 0 & $2(2,9)$ & $1(1,1)$ & $5(0,8)$ & $8(0,9)$ \\
Cabouqueiro & 0 & $1(1,5)$ & 0 & 0 & $1(0,1)$ \\
Ferreiro & 0 & 0 & 0 & $16(2,7)$ & $16(1,9)$ \\
Serrador & 0 & 0 & 0 & $3(0,5)$ & $3(0,5)$ \\
Quitandeiro & 0 & 0 & 0 & $1(0,2)$ & $1(0,1)$ \\
Feitor & 0 & 0 & 0 & $4(0,7)$ & $4(0,5)$ \\
Boleeiro & 0 & 0 & 0 & $2(0,3)$ & $2(0,2)$ \\
Falquejador & 0 & 0 & 0 & $8(1,4)$ & $8(0,9)$ \\
Pastor & 0 & 0 & 0 & $1(0,2)$ & $1(0,1)$ \\
Oleiro & 0 & 0 & 0 & $1(0,2)$ & $1(0,1)$ \\
Canoeiro & 0 & 0 & 0 & $2(0,3)$ & $2(0,2)$ \\
Alambiqueiro & 0 & 0 & 0 & $1(0,2)$ & $1(0,1)$ \\
Cargueiro & 0 & 0 & 0 & $5(0,8)$ & $5(0,6)$ \\
Alfaiate & 0 & 0 & 0 & $1(0,2)$ & $1(0,1)$ \\
Pajé & 0 & 0 & 0 & $4(0,7)$ & $4(0,5)$ \\
Tropeiro & 0 & 0 & 0 & $2(0,3)$ & $2(0,2)$ \\
Cozinheiro & $1(1,4)$ & $1(1,5)$ & $1(1,1)$ & $2(0,3)$ & $5(0,6)$ \\
Total & $72(100,0)$ & $68(100,0)$ & $98(100,0)$ & $590(100,0)$ & $828(100,0)$ \\
\hline & & & & & \\
\hline
\end{tabular}

FONTES: Inventários post-mortem de escravistas de Angra dos Reis, 1800-1888. Museu da Justiça do Estado do Rio de Janeiro, RJ.

Também entre as mulheres, 72,2\% estavam envolvidas em funções vinculadas à terra. As atividades associadas à casa compreendiam 18,9\% das cativas. 


\section{TABELA 28}

Atividades exercidas pelas escravas mulheres, segundo os inventários, por subperíodos. Angra dos Reis, 1800-1888

\begin{tabular}{c|c|c|c|c|c|c|c|c}
\hline Atividades & $\begin{array}{c}1800-1815 \\
\mathrm{n}^{\circ}(\%)\end{array}$ & $\begin{array}{c}1816-1826 \\
\mathrm{n}^{\circ}(\%)\end{array}$ & $\begin{array}{c}1827-1837 \\
\mathrm{n}^{\circ}(\%)\end{array}$ & $\begin{array}{c}1838-1848 \\
\mathrm{n}^{\circ}(\%)\end{array}$ & $\begin{array}{c}1849-1859 \\
\mathrm{n}^{\circ}(\%)\end{array}$ & $\begin{array}{c}1860-1871 \\
\mathrm{n}^{\circ}(\%)\end{array}$ & $\begin{array}{c}1872-1888 \\
\mathrm{n}^{\circ}(\%)\end{array}$ & $\begin{array}{c}\text { Total } \\
\mathrm{n}^{\circ}(\%)\end{array}$ \\
\hline Roça & 0 & $17(60,7)$ & $81(76,4)$ & $96(81,4)$ & $80(74,2)$ & $140(64,8)$ & $36(76,6)$ & $450(72,2)$ \\
Doméstico & 0 & $11(39,3)$ & $18(17,0)$ & $16(13,7)$ & $17(15,7)$ & $46(21,3)$ & $10(21,3)$ & $118(18,9)$ \\
Cozinheira & 0 & 0 & $2(1,9)$ & $1(0,8)$ & $5(4,7)$ & $5(2,3)$ & $1(2,1)$ & $14(2,2)$ \\
Lavadeira & 0 & 0 & $1(0,9)$ & 0 & $2(1,8)$ & $5(2,3)$ & 0 & $8(1,3)$ \\
Engomadeira & 0 & 0 & $1(0,9)$ & $1(0,8)$ & 0 & $6(2,8)$ & 0 & $8(1,3)$ \\
Costureira & 0 & 0 & $3(2,9)$ & $3(2,5)$ & $2(1,8)$ & $12(5,6)$ & 0 & $20(3,2)$ \\
Mucama & 0 & 0 & 0 & $1(0,8)$ & $2(1,8)$ & $2(0,9)$ & 0 & $5(0,9)$ \\
Total & 0 & $28(100,0)$ & $106(100,0)$ & $118(100,0)$ & $108(100,0)$ & $216(100,0)$ & $47(100,0)$ & $623(100,0)$ \\
\hline
\end{tabular}

FONTES: Inventários post-mortem de escravistas de Angra dos Reis, 1800-1888. Museu da Justiça do Estado do Rio de Janeiro, RJ.

Também nas grandes propriedades havia escravas com diferentes ocupações, como lavadeiras, costureiras e engomadeiras.

\section{TABELA 29}

Atividades exercidas pelas escravas mulheres, segundo as faixas de tamanho de propriedades. Angra dos Reis, 1800-1888

\begin{tabular}{c|c|c|c|c|c}
\hline Atividades & $\begin{array}{c}1-5 \\
\text { escravos } \\
\mathrm{n}^{\circ}(\%)\end{array}$ & $\begin{array}{c}6-10 \\
\text { escravos } \\
\mathrm{n}^{\circ}(\%)\end{array}$ & $\begin{array}{c}11-20 \\
\text { escravos } \\
\mathrm{n}^{\circ}(\%)\end{array}$ & $\begin{array}{c}21 \text { escravos } \\
\text { ou mais } \\
\mathrm{n}^{\circ}(\%)\end{array}$ & $\begin{array}{c}\text { Total } \\
\mathrm{n}^{\circ}(\%)\end{array}$ \\
\hline Roça & $23(60,5)$ & $39(60,9)$ & $70(70,0)$ & $318(75,5)$ & $450(72,2)$ \\
Doméstico & $9(23,7)$ & $18(28,1)$ & $25(25,0)$ & $66(15,7)$ & $118(18,9)$ \\
Cozinheira & $2(5,3)$ & $3(4,7)$ & $3(3,0)$ & $6(1,4)$ & $14(2,2)$ \\
Lavadeira & $1(2,6)$ & $1(1,6)$ & 0 & $6(1,4)$ & $8(1,3)$ \\
Engomadeira & $1(2,6)$ & 0 & 0 & $7(1,7)$ & $8(1,3)$ \\
Costureira & $1(2,6)$ & $1(1,6)$ & $2(2,0)$ & $16(3,8)$ & $20(3,2)$ \\
Mucama & $1(2,6)$ & $2(3,1)$ & 0 & $2(0,5)$ & $5(0,8)$ \\
Total & $38(100,0)$ & $64(100,0)$ & $100(100,0)$ & $421(100,0)$ & $623(100,0)$ \\
\hline
\end{tabular}

FONTES: Inventários post-mortem de escravistas de Angra dos Reis, 1800-1888. Museu da Justiça do Estado do Rio de Janeiro, RJ.

Portanto, grande parte dos escravos viviam em grandes propriedades. Dentre os cativos avaliados, houve um ligeiro predomínio dos homens. Por faixas etárias, destacaram-se os adultos, mas a participação de crianças era intensa.

No entanto, comparando-se os dados para a primeira e a segunda metade dos oitocentos, observamos um processo de envelhecimento dos escravos, resultante do término do tráfico Atlântico, em 1850. 
Todos eles, homens e mulheres, trabalhavam, principalmente, na roça, o que coincidia com a ocupação de seus proprietários.

Finalmente, colocando em paralelo os informes encontrados para a primeira e a segunda parte do século XIX, verificamos um aumento da participação de inventariados não escravistas. Observamos maior incidência de inventários comprometidos com elevadas somas em dívidas passivas, além de patrimônios totalmente perdidos com a arrematação dos bens, visando o pagamento dos credores.

Houve a manutenção de pequenos escravistas, que era o modelo mais comum de senhor de escravos em Angra dos Reis, assim como viver em grandes escravarias foi a experiência da maior parte dos cativos locais. Entretanto, a participação dos últimos diminuiu percentualmente, após 1850. Ocorreu também a redução de adultos e de africanos em todas as FTP.

Diante do exposto, não podemos deixar de considerar que houve mudanças econômicas e demográficas em Angra dos Reis, no século XIX. 


\section{PARTE II}

\section{FAMÍLIAS ESCRAVAS E SEUS GRAUS DE LEGITIMIDADE}

\section{INTRODUÇÃO}

As pesquisas sobre famílias escravas ${ }^{94}$ derrubaram as idéias de que a vida dos cativos esteve baseada na promiscuidade (cf. RODRIGUES, 1988; FREYRE, 1992), que a instituição familiar não foi comum em suas vidas e que, quando conseguiam estabelecer laços parentais, eram instáveis e de curta duração (cf. GORENDER, 1992; COSTA, 1988; CARDOSO, 1962).

Hoje, após trinta anos de estudos sobre o tema, as pesquisas buscam:

“aprofundar cada vez mais a análise das características apresentadas pela família cativa, sua estabilidade possível, seus vínculos com a atividade econômica encetada e com o tamanho dos plantéis de escravos. Sobretudo, estuda-se a questão da natureza mesma dessa instituição familiar e o papel a ela reservado no período escravista brasileiro” (MOTTA, 2002, p. 251-252).

Visando contribuir para o alargamento dos conhecimentos sobre os laços familiares, nos dedicamos, nos próximos capítulos, às famílias formadas por cativos que viveram e trabalharam em Angra dos Reis, no litoral sul-fluminense, entre 1801 e 1888.

Na presente parte, visamos comprovar: em primeiro lugar, que as famílias escravas existentes em Angra eram formadas, majoritariamente, por mulheres solteiras, aos olhos da Igreja, e por seus filhos. Esta tendência decorreu, principalmente, da falta de interesse dos senhores em verem seus cativos sacramentarem suas uniões. Segundo a Igreja, cativos unidos em matrimônio não poderiam ser separados durante a venda. Tal intervenção não era bem vista pelos senhores, principalmente os angrenses, que conviveram com um quadro de abatimento econômico, ao longo do Oitocentos. Portanto, melhor seria que os escravos não estivessem envoltos em laços de casamento. Talvez os

\footnotetext{
${ }^{94}$ Um balanço historiográfico sobre o tema é encontrado na Introdução. (cf. GRAHAM, 1979; SLENES, 1976; SLENES, 1987; LUNA \& COSTA, 1981; LUNA, 1990; FRAGOSO \& FLORENTINO, 1987; SCHWARTZ, 1995; SLENES, 1999; FARIA, 1998. MOTTA; 1999a).
} 
cativos tenham se desinteressado pelo matrimônio, e outros tenham encontrado dificuldades em encontrar parceiros nos plantéis em que trabalhavam.

Em segundo, mostramos que com o passar dos anos, a freqüência de famílias formadas pela ilegitimidade aumentou, exatamente quando se agravaram os problemas relativos à reposição de mão-de-obra no Brasil. Neste momento, quando o preço dos cativos aumentou, muitos senhores, estando em dificuldades, encontraram como alternativa vender seus cativos às áreas de ponta da economia imperial.

Entretanto, o desinteresse senhorial era um dos aspectos a explicar o perfil familiar. Citamos, aqui, também, o possível desinteresse de cativos e, o que consideramos mais pertinente, a dificuldade na localização de companheiros. Nos capítulos anteriores ficou constatado que o número de escravos sofreu grande decréscimo na segunda metade dos oitocentos, e que houve um processo de crioulização da população não-liberta. Ambos acontecimentos aumentaram, possivelmente, as dificuldades na localização de parceiros entre os cativos de mesmo senhor, pois uma condição para a oficialização das uniões entre escravos era que os noivos pertencessem ao mesmo escravista.

Em terceiro, analisamos o perfil dos escravos que “chegaram ao altar”. Quando os cativos casavam, os cônjuges apresentavam, em geral, características comuns relativas à origem e à propriedade. Tais aspectos acabavam por “dar uma cara” aos casais.

Em quarto lugar, verificamos a maternidade escrava. Ter filhos entre os escravos de Angra significava um dos meios para a constituição de famílias. Comparamos a procriação entre as mães casadas e as solteiras, como o intervalo entre os nascimentos. Embora seja essencial a maternidade a fim de formar um novo núcleo familiar, as casadas, em função da proximidade de seus consortes, possuíam um menor intervalo entre os nascimentos de seus filhos.

Para verificar todas as questões explicitadas, trabalhamos com os registros de casamento e de batismo de escravos encontrados no Convento do Carmo e na Igreja de Jacuecanga, em Angra dos Reis. Após o levantamento do material, cruzamos os dados com os informes recolhidos nos inventários post-mortem.

Entretanto, a maior parte dos documentos pesquisados foram produzidos pela Igreja Católica. Portanto, a compreensão de família ficou condicionada à concepção da Igreja. Por exemplo, um filho legítimo, definido em registro de batismo, era uma criança 
nascida de pais unidos em matrimônio. Da mesma forma que um batizando natural foi gerado por um ventre de mulher solteira. Ela, tanto poderia estar participando de uma relação estável, quanto poderia ter tido seus filhos acidentalmente. Conseqüentemente, sempre que tratarmos de mulheres com filhos, estamos compreendendo que as mães não participavam de uniões legitimadas ${ }^{95}$.

A Parte II está dividida em três capítulos: no capítulo 4 nos dedicamos à verificação das duas questões assinaladas, ou seja, as características das famílias quanto à legitimidade e sua evolução ao longo do tempo; no capítulo 5 analisamos o perfil dos casais escravos; no capítulo 6, estudamos as mães casadas e solteiras e os padrões de maternidade.

\footnotetext{
${ }^{95}$ Na parte III alargamos a visão de família, compreendendo que o laço de compadrio era um meio no qual os escravos agregavam outros indivíduos a fim de fazer parte de suas famílias. Na parte IV observamos que os cativos não conviviam apenas com pais, padrinhos e madrinhas, mas também com avós e tios.
} 


\section{CAPÍTULO 4-FAMÍLIAS NUCLEARES E FAMÍLIAS MATRIFOCAIS}

Analisamos as características das famílias formadas entre 1800 e $1888^{96}$, numa localidade cujo perfil econômico voltava-se para o consumo e o mercado interno, além de dedicar-se ao transporte do café. Observamos também de que forma as ditas características foram alteradas em decorrência da transformação econômica e demográfica verificada na região, com o passar da segunda metade do século XIX.

As famílias legitimadas pelo matrimônio não foram predominantes em Angra, correspondendo a 23,1\%, entre 1800 e 1888. As constituídas por mães solteiras e seus filhos, representaram 76,9\%. As últimas resultaram, quer de uniões estáveis, quer de encontros acidentais (cf. tabela 30).

A representatividade de mães solteiras e filhos, já marcante na primeira metade do século XIX, tornou-se mais intensa após 1850, num momento de transformação econômica e demográfica. Unindo os dados da tabela 30, encontramos: 67,8\% de famílias matrifocais, entre 1800 e 1848, e 83,9\%, entre 1849 e 1888. Enquanto isso, os percentuais para as famílias nucleares foram de, respectivamente, 32,2\% e 16,1\%.

Este perfil resultou do desinteresse senhorial na oficialização da união de seus cativos, evitando, assim, a intervenção da Igreja em sua relação com os escravos e, particularmente, quando houvesse necessidade de vender separadamente um dos cônjuges. Esta preocupação aumentou na segunda metade do século XIX, num contexto onde a oferta de cativos africanos havia cessado e existia um mercado ávido por adquirir novos braços. Neste momento, muitos senhores estavam encontrando dificuldades em manter suas atividades produtivas e acabaram recorrendo ao tráfico interno, não para adquirir trabalhadores, mas para vender seus escravos. Tais negociações foram facilitadas quando envolveram cativos solteiros aos olhos da Igreja. Esta atitude dos senhores foi mantida mesmo após a lei de $1869^{97}$, que proibia a separação das famílias, legais ou não (SLENES, 1999, p. 100-101).

No caso de senhores que apoiassem ou tolerassem o casamento de seus escravos, os últimos deveriam buscar cônjuges nos limites das propriedades em que viviam e

\footnotetext{
${ }^{96}$ O recorte temporal esteve condicionado à disponibilidade de inventários.

${ }^{97}$ Os proprietários poderiam ter burlado a lei, por exemplo, indicando uma criança com menos de 12 anos, como de filiação desconhecia. Tal atitude apareceu em alguns inventários de Angra posteriores a 1869.
} 
trabalhavam $^{98}$. Entretanto, na segunda metade dos oitocentos a diminuição do número de cativos representou a redução de trabalhadores de muitos plantéis e, conseqüentemente, menor oferta de possíveis noivos. Já o processo de “crioulização” daqueles que continuaram em cativeiro promoveu a formação de escravarias que dispunham de laços parentais $^{99}$. Os dois movimentos geraram uma dificuldade na localização de parceiros nos limites das propriedades. Alguns cativos conseguiram casar. Entretanto, a maior parte buscou seus companheiros, quando escravos, nas propriedades vizinhas, inviabilizando a oficialização da união. Outros se associaram aos forros e, os demais, aos livres.

TABELA 30

Freqüência de famílias nucleares e matrifocais presentes nos inventários. Angra dos Reis, 1800-1888

\begin{tabular}{c|c|c|c|c|c|c|c|c}
\hline $\begin{array}{c}\text { Tipos de } \\
\text { famílias }\end{array}$ & $\begin{array}{c}1800-1815 \\
\mathrm{n}^{\circ}(\%)\end{array}$ & $\begin{array}{c}1816-1826 \\
\mathrm{n}^{\circ}(\%)\end{array}$ & $\begin{array}{c}1827-1837 \\
\mathrm{n}^{\circ}(\%)\end{array}$ & $\begin{array}{c}1838-1848 \\
\mathrm{n}^{\circ}(\%)\end{array}$ & $\begin{array}{c}1849-1859 \\
\mathrm{n}^{\circ}(\%)\end{array}$ & $\begin{array}{c}1860-1871 \\
\mathrm{n}^{\circ}(\%)\end{array}$ & $\begin{array}{c}1872-1888 \\
\mathrm{n}^{\circ}(\%)\end{array}$ & $\begin{array}{c}\text { Total } \\
\mathrm{n}^{\circ}(\%)\end{array}$ \\
\hline $\begin{array}{c}\text { Famílias } \\
\text { nucleares }\end{array}$ & $2(100,0)$ & $4(22,2)$ & $29(43,9)$ & $11(19,3)$ & $13(26,5)$ & $12(11,9)$ & $5(13,9)$ & $76(23,1)$ \\
$\begin{array}{c}\text { Famílias } \\
\text { matrifocais } \\
\text { Total }\end{array}$ & 0 & $14(77,8)$ & $37(56,1)$ & $46(80,7)$ & $36(73,5)$ & $89(88,1)$ & $31(86,1)$ & $253(76,9)$ \\
& $2(100,0)$ & $18(100,0)$ & $66(100,0)$ & $57(100,0)$ & $49(100,0)$ & $101(100,0)$ & $36(100,0)$ & $329(100,0)$ \\
\hline
\end{tabular}

FONTES: Inventários post-mortem de escravistas de Angra dos Reis, 1800-1888. Museu da Justiça do Estado do Rio de Janeiro, RJ.

A diminuição de uniões perante a Igreja, ao longo do século XIX, foi vista, também, em outras localidades das províncias do Rio de Janeiro e de São Paulo.

Faria (1998) verificou, nos séculos XVII e XVIII, uma variação da legitimidade. Esta decorreu das características das regiões analisadas. Áreas com ilegitimidade acima de 66\% tinham em comum o fato de estarem próximas a portos, garantindo a reposição da mão-de-obra africana, e de bispados, embora com atividades econômicas variadas. A proximidade de bispado oferecia maior interferência da Igreja nas relações entre senhores e escravos, podendo, inclusive, vir a dificultar a venda de um dos cônjuges. Localidades com alta legitimidade compreendiam áreas rurais e relativamente distantes de portos e de bispados (FARIA, 1998, p. 324).

No entanto, no século XIX as diferenças anteriormente vistas desapareceram, em prol do aumento da ilegitimidade entre as crianças escravas. A partir daquele século, num

\footnotetext{
${ }^{98}$ Os casamentos no Brasil ocorriam, geralmente, entre escravos de um mesmo senhor.

${ }^{99}$ A crioulização resultou da reprodução natural.
} 
momento de acirramento das pressões inglesas em favor da abolição do tráfico de escravos africanos, culminando na Lei de 1831 e na Lei de 1850, levaram a uma mudança de atitude senhorial com relação a seus cativos. Enquanto a reposição de mão-de-obra era facilmente garantida, a intervenção da Igreja nas relações senhor-escravo era amenizada. Contudo quando a oferta de trabalhadores diminuiu, não se poderia mais admiti-la. Daí o aumento da ilegitimidade e, é claro, de diminuição de casamentos entre escravos: “cristalizou o processo de interferência direta dos senhores na vida particular dos negros cativos” (FARIA, 1998, p. 339). Ao lado disso, a autora levantou, também, a hipótese do aumento de práticas africanas, que passaram a ditar as vidas e as formas de organização familiar, em decorrência do grande desembarque de cativos africanos na primeira metade do século XIX.

Florentino \& Góes (1997, p. 141-144) observaram a diminuição de famílias legitimadas no agro fluminense, na primeira metade do século XIX. Segundo eles, o aumento do número de africanos, correspondendo à chegada de estrangeiros, de não aparentados, gerou uma urgência na criação de laços, fazendo com que eles se unissem, sem passar necessariamente pelo sacramento do matrimônio.

A partir da comparação dos números de escravos casados, viúvos e filhos legítimos e os de mães solteiras e filhos naturais, encontrados em Lorena, em 1801, e em Lorena e Cruzeiro, em 1874, Motta \& Marcondes (2000, p. 109) verificaram a diminuição percentual de escravos envolvidos em famílias legitimadas e o aumento de cativos ligados às formadas por mães solteiras. Os percentuais de escravos que participaram das famílias legitimadas foram de 38,8\%, no ano de 1801, e de $27 \%$, em 1874. Os trabalhadores compulsórios vinculados às famílias formadas por mães solteiras corresponderam a 14,2\% dos escravos, no início do século, e 26,0\%, na década de 1870 (MOTTA \& MARCONDES, 2000, p. 109-110).

Slenes (1999), analisando a queda, após 1850, do número de escravos que experimentaram o matrimônio, nas províncias do Rio de Janeiro e de São Paulo, constatou que a diminuição foi maior na primeira. A diferença era explicada a partir do grau de envolvimento dos senhores de São Paulo com o catolicismo, em comparação com os do Rio de Janeiro. Em suas palavras, 
“A relação peculiar entre Estado, Igreja e sociedade em São Paulo não apenas teria incidido diretamente nas taxas de nupcialidade, mas teria mantido ou fortalecido um clima 'ideológico' no seio da elite, favorável à idéia do casamento religioso como instituição benéfica e moralizadora para todas as classes sociais” (SLENES, 1999, p. 91).

Isto explicaria, inclusive, a tendência à diminuição da taxa citada nas localidades fluminenses à medida que se distanciavam de São Paulo.

Como decorrência da representatividade de famílias matrifocais, em Angra dos Reis, e seu aumento percentual ao longo dos anos, a principal referência dos escravos foi a ilegitimidade. Portanto, dos cativos com laços parentais, 74,6\% viviam em famílias encabeçadas por mulheres solteiras. Enquanto isso, 25,4\% dos trabalhadores compulsórios participavam de famílias nucleares. Os últimos representaram 35,9\% dos escravos envolvidos em famílias, nos anos de 1800 até 1848. De 1849 a 1888, o percentual reduziu-se para 17,0\%. Nos subperíodos de 1860-1871 e de 1872-1888, apenas 13,0\% estavam na presença de seus cônjuges, pais e filhos.

\section{TABELA 31}

Freqüência de escravos envolvidos em laços familiares nucleares e matrifocais, presentes nos inventários. Angra dos Reis, 1800-1888

\begin{tabular}{c|c|c|c|c|c|c|c|c}
\hline $\begin{array}{c}\text { Tipos de } \\
\text { famílias }\end{array}$ & $\begin{array}{c}1800-1815 \\
\mathrm{n}^{\circ}(\%)\end{array}$ & $\begin{array}{c}1816-1826 \\
\mathrm{n}^{\circ}(\%)\end{array}$ & $\begin{array}{c}1827-1837 \\
\mathrm{n}^{\circ}(\%)\end{array}$ & $\begin{array}{c}1838-1848 \\
\mathrm{n}^{\circ}(\%)\end{array}$ & $\begin{array}{c}1849-1859 \\
\mathrm{n}^{\circ}(\%)\end{array}$ & $\begin{array}{c}1860-1871 \\
\mathrm{n}^{\circ}(\%)\end{array}$ & $\begin{array}{c}1872-1888 \\
\mathrm{n}^{\circ}(\%)\end{array}$ & $\begin{array}{c}\text { Total } \\
\mathrm{n}^{\circ}(\%)\end{array}$ \\
\hline $\begin{array}{c}\text { Famílias } \\
\text { nucleares }\end{array}$ & $8(100,0)$ & $15(27,3)$ & $94(44,5)$ & $41(24,7)$ & $40(29,2)$ & $38(13,0)$ & $16(13,0)$ & $252(25,4)$ \\
$\begin{array}{c}\text { Famílias } \\
\text { matrifocais }\end{array}$ & 0 & $40(72,7)$ & $117(55,5)$ & $125(75,3)$ & $97(70,8)$ & $254(87,0)$ & $107(87,0)$ & $740(74,6)$ \\
$\quad$ Total & $8(100,0)$ & $55(100,0)$ & $211(100,0)$ & $166(100,0)$ & $137(100,0)$ & $292(100,0)$ & $123(100,0)$ & $992(100,0)$ \\
\hline
\end{tabular}

FONTES: Inventários post-mortem de escravistas de Angra dos Reis, 1800-1888. Museu da Justiça do Estado do Rio de Janeiro, RJ.

Entretanto, não houve apenas redução da participação de escravos em famílias nucleares, em geral, houve uma diminuição de escravos envolvidos nos dois tipos de famílias $^{100}$ : entre 1800 e 1848, 39,3\% dos escravos avaliados foram citados como estando

\footnotetext{
100 Tratam-se dos laços consangüíneos e matrimoniais. No caso deles, sim, observamos uma diminuição percentual dos escravos envoltos naqueles vínculos. No entanto, como já foi dito no início do estudo, consideramos como famílias escravas, não apenas as matrifocais e nucleares, mas também o apadrinhamento e as famílias extensas. Nos próximos capítulos, estudaremos o batismo e as famílias formadas por três ou mais gerações.
} 
inseridos em famílias; já nos anos de 1849 até 1888, a participação foi de 34,5\%. A diminuição percentual deve ter resultado do aumento de inventários sem informações sobre as famílias. Agindo assim, os avaliadores e herdeiros poderiam ter mais liberdade para separar os grupos parentais ${ }^{101}$.

Não obstante, quando incluímos os escravos que participavam de famílias fraternas e extensas, constatamos que, ao contrário de uma redução do parentesco, houve um aumento da participação de cativos em família, correspondendo a 40,9\%, até 1849, e 41,2\%, após 1850. Estes percentuais foram encontrados após o cruzamento de registros paroquiais com inventários e, quando possível, com as matrículas de escravos, de 1872.

\section{TABELA 32}

Freqüência de escravos envolvidos em laços familiares nucleares e matrifocais, presentes nos inventários, sobre o total de escravos avaliados. Angra dos Reis, 1800-1888

\begin{tabular}{|c|c|c|c|c|c|c|c|c|}
\hline $\begin{array}{l}\text { Tipos de } \\
\text { famílias }\end{array}$ & $\begin{array}{c}1800-1815 \\
n^{\circ}(\%)\end{array}$ & $\begin{array}{c}1816-1826 \\
n^{\circ}(\%)\end{array}$ & $\begin{array}{c}1827-1837 \\
\mathrm{n}^{\circ}(\%)\end{array}$ & $\begin{array}{c}1838-1848 \\
\mathrm{~N}^{\circ}(\%) \\
\end{array}$ & $\begin{array}{c}1849-1859 \\
\mathrm{n}^{\circ}(\%)\end{array}$ & $\begin{array}{c}1860-1871 \\
n^{\circ}(\%)\end{array}$ & $\begin{array}{c}1872-1888 \\
n^{\circ}(\%)\end{array}$ & $\begin{array}{c}\text { Total } \\
\mathrm{n}^{\circ}(\%)\end{array}$ \\
\hline $\begin{array}{c}\text { Escravos } \\
\text { com laços } \\
\text { familiares }\end{array}$ & $8(34,8)$ & $55(30,2)$ & $211(48,5)$ & $166(34,6)$ & $137(34,6)$ & $292(32,8)$ & $123(46,2)$ & $992(36,5)$ \\
\hline $\begin{array}{c}\text { Total de } \\
\text { escravos } \\
\text { avaliados }\end{array}$ & $23(100,0)$ & $182(100,0)$ & $435(100,0)$ & $479(100,0)$ & $443(100,0)$ & $890(100,0)$ & $266(100,0)$ & $2.718(100,0)$ \\
\hline
\end{tabular}

FONTES: Inventários post-mortem de escravistas de Angra dos Reis, 1800-1888. Museu da Justiça do Estado do Rio de Janeiro, RJ.

Não podemos deixar afirmar que, mesmo diante das dificuldades encontradas pelos escravos, em torno de $30 \%$ dos cativos anotados em inventários estavam com seus familiares $^{102}$, no caso seus maridos e/ou filhos. Portanto, será que a realidade escravista estimulava a promiscuidade? Os cativos eram simples “marionetes” nas mãos de seus senhores? Será que não era importante para os escravos, e para alguns senhores, a socialização parental?

A vida dos escravos não se baseava na promiscuidade, e muito menos, os cativos eram apenas "mercadorias”. Pelo contrário, tanto os senhores quanto seus escravos, estavam em constante negociação. Uns, procurando manter o trabalho e a autoridade

${ }^{101} \mathrm{Na}$ parte IV, observamos que houve, em alguns casos, desinteresse dos avaliadores em indicar os vínculos parentais dos cativos.

${ }^{102}$ Esse percentual, com certeza, seria maior se incluíssemos os padrinhos, as madrinhas, os tios e as avós. 
sobre suas “peças” e os outros, formas de melhor sobreviver. Neste jogo de “interesses”, a família apareceu como um meio de garantir a permanência do cativo na propriedade, já que evitaria fugir e deixar seus parentes, assim como ofereceu aos escravizados, humanidade, solidariedade e sociabilidade.

A condição de riqueza, observada a partir do número de escravos nas propriedades, influenciava o perfil familiar.

TABELA 33

Freqüência de famílias nucleares e matrifocais por subperíodos e faixas de tamanho de propriedades.

Angra dos Reis, 1800-1888

\begin{tabular}{|c|c|c|c|c|c|c|c|c|}
\hline FTP & $\begin{array}{c}1800-1815 \\
n^{\circ}(\%)\end{array}$ & $\begin{array}{c}1816-1826 \\
n^{\circ}(\%)\end{array}$ & $\begin{array}{c}1827-1837 \\
\mathrm{n}^{\circ}(\%)\end{array}$ & $\begin{array}{c}1838-1848 \\
\mathrm{n}^{\circ}(\%)\end{array}$ & $\begin{array}{c}1849-1859 \\
n^{\circ}(\%)\end{array}$ & $\begin{array}{c}1860-1871 \\
\mathrm{n}^{\circ}(\%)\end{array}$ & $\begin{array}{c}1872-1888 \\
n^{\circ}(\%)\end{array}$ & $\begin{array}{c}\text { Total } \\
\mathrm{n}^{\circ}(\%)\end{array}$ \\
\hline \multicolumn{9}{|l|}{$1-5$} \\
\hline FN & 0 & 0 & 0 & 0 & 0 & 0 & $1(25,0)$ & $1(4,3)$ \\
\hline FM & 0 & 0 & $4(100,0)$ & $3(100,0)$ & $5(100,0)$ & $7(100,0)$ & $3(75,0)$ & $22(95,7)$ \\
\hline St & 0 & 0 & $4(100,0)$ & $3(100,0)$ & $5(100,0)$ & $7(100,0)$ & $4(100,0)$ & $23(100,0)$ \\
\hline \multicolumn{9}{|l|}{$6-10$} \\
\hline FN & 0 & 0 & $1(33,4)$ & 0 & $1(14,3)$ & 0 & 0 & $2(6,2)$ \\
\hline FM & 0 & $1(100,0)$ & $2(66,7)$ & $8(100,0)$ & $6(85,7)$ & $11(100,0)$ & $2(100,0)$ & $30(93,8)$ \\
\hline St & 0 & $1(100,0)$ & $3(100,0)$ & $8(100,0)$ & $7(100,0)$ & $11(100,0)$ & $2(100,0)$ & $32(100,0)$ \\
\hline \multicolumn{9}{|c|}{$11-20$} \\
\hline FN & $2(100,0)$ & $3(25,0)$ & 0 & 0 & 0 & $7(25,9)$ & $3(21,4)$ & $15(22,4)$ \\
\hline FM & 0 & $9(75,0)$ & $4(100,0)$ & $5(100,0)$ & $3(100,0)$ & $20(74,1)$ & $11(78,6)$ & $52(77,6)$ \\
\hline St & $2(100,0)$ & $12(100,0)$ & $4(100,0)$ & $5(100,0)$ & $3(100,0)$ & $27(100,0)$ & $14(100,0)$ & $67(100,0)$ \\
\hline \multicolumn{9}{|c|}{21 ou mais } \\
\hline FN & 0 & $1(20,0)$ & $28(50,9)$ & $11(26,8)$ & $12(35,3)$ & $5(8,9)$ & $1(6,3)$ & $58(28,0)$ \\
\hline FM & 0 & $4(80,0)$ & $27(49,1)$ & $30(73,2)$ & $22(64,7)$ & $51(91,1)$ & $15(93,7)$ & $149(72,0)$ \\
\hline St & 0 & $5(100,0)$ & $55(100,0)$ & $41(100,0)$ & $34(100,0)$ & $56(100,0)$ & $16(100,0)$ & $207(100,0)$ \\
\hline
\end{tabular}

FONTES: Inventários post-mortem de escravistas de Angra dos Reis, 1800-1888. Museu da Justiça do Estado do Rio de Janeiro, RJ.

NOTAS: FTP=faixa de tamanho de propriedades; FN=famílias nucleares; FM=famílias matrifocais; St=subtotal.

Notamos que, à medida que aumentava a FTP, a freqüência de famílias nucleares elevava-se e a representatividade das matrifocais diminuía. Nas propriedades com até cinco cativos, 95,7\% das famílias eram formadas por mães solteiras; na FTP de 6-10, o percentual chegou a 93,8\%; entre os senhores com 11 a 20 escravos, 77,6\%; e nas grandes propriedades, 72,0\%. Logo, existiu, entre 1800 e 1888, uma correlação entre FTP e os tipos de famílias mais freqüentes.

Houve uma tendência, no Brasil, de casamentos entre escravos de mesmo senhor $^{103}$ : para a freguesia repleta de canaviais de São Gonçalo do Recôncavo da

\footnotetext{
${ }^{103}$ No próximo capítulo, retornaremos à questão.
} 
Guanabara, no século XVII, 97,1\% dos casamentos envolveram escravos de mesma propriedade (FARIA, 1998, p. 315). Semelhante tendência foi vista na Bahia Colonial (SCHWARTZ, 1995, p. 313), e em Lorena, em 1801, quando o café ainda não era o cultivo predominante, onde "deve-se notar, por fim, a baixa incidência de casamentos entre elementos não pertencentes ao mesmo escravista; vale dizer, raros eram os casos de uniões entre pessoas de plantéis diferentes" (COSTA, SLENES \& SCHWARTZ, 1987, p. 254-257).

Por conseguinte, plantéis com maior número de cativos facilitaram a localização de possíveis cônjuges. Dado encontrado, por exemplo, para Lorena e Cruzeiro, áreas caracterizadas por produção de alimentos, de café, de cana e início de uma atividade comercial, em 1874. Dos cativos de propriedades com até quatro escravos, 16,7\% estavam envolvidos em uniões legítimas, contra $71,6 \%$ de escravos das propriedades com 40 ou mais cativos (MOTTA \& MARCONDES, 2000, p. 111). Em Bananal, nos anos de 1801, antes da difusão do café na localidade, em 1817, no momento de introdução do cultivo, e em 1829, quando a região caminhava para plantation, as freqüências de casados e de viúvos aumentaram com a elevação do número de cativos por propriedades (MOTTA, 1999a, p. 307).

O maior número de casamentos nas maiores propriedades ocorreu mesmo tendo elevadas razões de sexo. Dentre outros, Luna (1992, p. 458), em estudo sobre 25 localidades de São Paulo nos anos de 1777, de 1804 e de 1829, afirmou que:

"Nos maiores plantéis, apesar da alta razão de masculinidade, a influência do tamanho do plantel na determinação da proporção de casamentos mostrava-se suficientemente forte para provocar maior proporção de casamentos”.

O mesmo foi encontrado por Costa \& Nozoe (1989, p. 342) em Lorena, no ano de 1801, onde os percentuais de escravos casados e viúvos, calculados sobre a população escrava acima de 14 anos, e o número de homens escravos, tenderam a aumentar com a faixa de tamanho dos plantéis.

Portanto, quanto maior a propriedade, maiores eram as chances dos cativos encontrarem parceiros e, caso desejassem, legalizar suas uniões. Assim sendo, a freqüência de famílias nucleares, em Angra, elevava-se nas maiores escravarias. 
Em Angra, nos anos de 1800 até 1848, as famílias ilegítimas corresponderam a 100,0\%, 91,7\%, 78,3\% e 60,4\%, respectivamente nas FTP de 1-5, de 6-10, de 11-20 e de 21 ou mais cativos. Famílias formadas a partir do casamento não foram localizadas na FTP de 1-5; mas chegaram a 8,3\%, na FTP de 6-10; 21,7\%, nas escravarias com 11 a 20 cativos; e 39,6\%, nas maiores propriedades.

Entretanto, entre 1849 e 1888, o maior percentual de famílias nucleares foi calculado nas escravarias com 11 a 20 escravos, e não nas maiores propriedades ${ }^{104}$. Já as matrifocais corresponderam a 93,7\%, 95,0\%, 77,3\% e 83,0\%, respectivamente, nas FTP de 1-5, de 6-10, de 11-20 e de 21 ou mais escravos.

Embora a participação da legitimidade fosse mais comum nas propriedades maiores, as famílias matrifocais predominaram em todas as FTP. Conseqüentemente, a maior parte dos cativos com indicação parental anotada nos inventários, participava de famílias formadas por mães não casadas.

Entre 1800 e 1888, 96,4\% dos aparentados, pertencentes aos pequenos proprietários, conviviam com suas mães solteiras; na FTP de 6-10, o percentual chegou a 90,1\%; na FTP de 11-20, 76,8\% dos escravos faziam parte de famílias matrifocais; e na FTP de 21 ou mais, 69,8\%.

Comparando-se a primeira e a segunda metade dos oitocentos, verificamos um aumento percentual, em praticamente todas as FTP, de escravos envolvidos em famílias matrifocais. Em ordem crescente de FTP, encontramos: 100,0\%, 82,3\%, 74,6\% e 58,0\%, nos anos de 1800 a 1848. De 1849 até 1888, os cativos pertencentes àquelas famílias corresponderam a $94,9 \%, 94,7 \%, 78,0 \%$ e $81,5 \%$, respectivamente.

\footnotetext{
${ }^{104}$ Os percentuais foram de: 6,3\%, 5,0\%, 22,7\% e 17,0\%, respectivamente, nas FTP de 1-5, 6-10, 11-20 e de 21 ou mais escravos.
} 
TABELA 34

Freqüência de escravos envolvidos em famílias nucleares e matrifocais por subperíodos e faixas de tamanho de propriedades. Angra dos Reis, 1800-1888

\begin{tabular}{|c|c|c|c|c|c|c|c|c|}
\hline FTP & $\begin{array}{c}1800-1815 \\
\mathrm{n}^{\circ}(\%)\end{array}$ & $\begin{array}{c}1816-1826 \\
\mathrm{n}^{\circ}(\%)\end{array}$ & $\begin{array}{c}1827-1837 \\
n^{\circ}(\%)\end{array}$ & $\begin{array}{c}1838-1848 \\
n^{\circ}(\%)\end{array}$ & $\begin{array}{c}1849-1859 \\
\mathrm{n}^{\circ}(\%)\end{array}$ & $\begin{array}{c}1860-1871 \\
\mathrm{n}^{\circ}(\%)\end{array}$ & $\begin{array}{c}1872-1888 \\
\mathrm{n}^{\circ}(\%)\end{array}$ & $\begin{array}{c}\text { Total } \\
\mathrm{n}^{\circ}(\%)\end{array}$ \\
\hline \multicolumn{9}{|l|}{$1-5$} \\
\hline FN & 0 & 0 & 0 & 0 & 0 & 0 & $2(20,0)$ & $2(3,6)$ \\
\hline FM & 0 & 0 & $10(100,0)$ & $6(100,0)$ & $13(100,0)$ & $16(100,0)$ & $8(80,0)$ & $53(96,4)$ \\
\hline St & 0 & 0 & $10(100,0)$ & $6(100,0)$ & $13(100,0)$ & $16(100,0)$ & $10(100,0)$ & $55(100,0)$ \\
\hline \multicolumn{9}{|l|}{$6-10$} \\
\hline FN & 0 & 0 & $6(60,0)$ & 0 & $3(16,6)$ & 0 & 0 & $9(9,9)$ \\
\hline FM & 0 & $2(100,0)$ & $4(40,0)$ & $22(100,0)$ & $15(83,4)$ & $29(100,0)$ & $10(100,0)$ & $82(90,1)$ \\
\hline St & 0 & $2(100,0)$ & $10(100,0)$ & $22(100,0)$ & $18(100,0)$ & $29(100,0)$ & $10(100,0)$ & $91(100,0)$ \\
\hline \multicolumn{9}{|l|}{$11-20$} \\
\hline FN & $8(100,0)$ & $10(27,0)$ & 0 & 0 & 0 & $17(23,0)$ & $12(23,5)$ & $47(23,2)$ \\
\hline FM & 0 & $27(73,0)$ & $12(100,0)$ & $14(100,0)$ & $7(100,0)$ & $57(77,0)$ & $39(76,5)$ & $156(76,8)$ \\
\hline St & $8(100,0)$ & $37(100,0)$ & $12(100,0)$ & $14(100,0)$ & $7(100,0)$ & $74(100,0)$ & $51(100,0)$ & $203(100,0)$ \\
\hline \multicolumn{9}{|c|}{21 ou mais } \\
\hline FN & 0 & $5(31,3)$ & $88(49,2)$ & $41(33,1)$ & $37(37,4)$ & $21(12,1)$ & $2(3,8)$ & $194(30,2)$ \\
\hline FM & 0 & $11(68,7)$ & $91(50,8)$ & $83(66,9)$ & $62(62,6)$ & $152(87,9)$ & $50(96,2)$ & $449(69,8)$ \\
\hline St & 0 & $16(100,0)$ & $179(100,0)$ & $124(100,0)$ & $99(100,0)$ & $173(100,0)$ & $52(100,0)$ & $643(100,0)$ \\
\hline
\end{tabular}

FONTES: Inventários post-mortem de escravistas de Angra dos Reis, 1800-1888. Museu da Justiça do Estado do Rio de Janeiro, RJ.

NOTAS: FN=famílias nucleares; FM=famílias matrifocais; $\mathrm{St}=$ subtotal.

As famílias matrifocais foram comuns em todas as FTP e, conseqüentemente, a maior parte dos escravos aparentados viviam em famílias encabeçadas por mães solteiras. Com o passar da segunda metade dos oitocentos, aumentou a freqüência de escravos que conviviam apenas com as suas mães, inclusive nas propriedades com seis ou mais cativos.

Portanto, verificamos que, assim como outros estudos, as famílias nucleares eram mais comuns nas grandes escravarias. No entanto, ao longo da segunda metade dos oitocentos, a freqüência daquelas diminuiu. Paralelamente, o percentual de escravos envolvidos em famílias matrifocais elevou-se. Isso ocorreu em todas as faixas de tamanho de propriedade.

Finalmente, em meio a um quadro de transformação econômica e demográfica, a participação de famílias ilegítimas, comuns na primeira metade do século XIX, aumentou. Isso resultou ora do desinteresse senhorial, ora do desinteresse dos escravos, ora da dificuldade encontrada por alguns cativos em envolver-se com parceiros dentre os trabalhadores pertencentes ao mesmo plantel. 


\section{CAPÍTULO 5-CASAMENTO ENTRE OS ESCRAVOS}

Mesmo com o predomínio de famílias ilegítimas, faz-se necessário o estudo dos casais escravos. Convidamos o leitor a conhecer um pouco sobre os casamentos dos escravos de Angra dos Reis.

Para a feitura do presente capítulo foram pesquisados 10 livros paroquiais, de batismos e de casamentos, referentes aos escravos, existentes para o município de Angra dos Reis, datados do século XIX ${ }^{105}$.

A fim de verificar as características dos casamentos, optamos pela divisão dos dados entre os subperíodos de 1830-1840, de 1841-1851, de 1852-1861, de 1864-1873 e de 1874-1886. A seleção dos subperíodos esteve condicionada às disponibilidades das fontes. Posteriormente, destacamos os informes para a primeira e a segunda metade do século XIX.

Feitas as considerações devidas, passemos aos casamentos...

Diante da ampliação do movimento protestante, caracterizado pela difusão do luteranismo e do calvinismo, a Igreja Católica dedicou-se à chamada Contra-Reforma, ou Reforma Católica. Esta reafirmou o sacramento do casamento, entendendo-o como importante mecanismo de controle sobre a vida de seus fiéis, buscando reforçar os “dogmas e regras sobre o casamento” (VAINFAS, 1997, p. 23). A Igreja, desta forma, opunha-se às idéias difundidas entre as populações européias que entendiam o casamento como contrato firmado no plano social, comunitário e familiar.

No Brasil, na busca por controlar o grande índice de ilegitimidade e de concubinato, a Igreja, desde o século XVI, divulgou o sacramento do matrimônio (VENÂNCIO, 1983, p. 107-123).

Em fins do século XVII e inícios do século XVIII, a Igreja no Brasil, mais bem organizada, desenvolveu uma campanha que incluía sermões, visitações e devassas e a elaboração de um código onde constavam as obrigações do clero e de seus fiéis. Este chamou-se Constituições Primeiras do Arcebispado da Bahia, de 1707, que defendiam “os interditos, a indissolubilidade e a universalidade do matrimônio” (VENÂNCIO, 1983, p. 109).

${ }^{105}$ Ver Apêndice metodológico. 
Os escravos tinham o direito de casar com indivíduos de qualquer situação social $^{106}$. Era assegurado a eles o privilégio a uma vida conjugal estável, sem maus-tratos e sem a ameaça de venda de um dos cônjuges. O sacramento, por sua vez, não representava a alforria e poderia ser realizado sem a autorização de seu proprietário. Existiam, entretanto, algumas obrigações a serem cumpridas (cf. SILVA, 1984).

Os noivos deveriam ter, no mínimo, 14 anos e as noivas, 12 anos; ambos teriam que conhecer a doutrina católica, devendo recitar o pai-nosso, a ave-maria, o credo e os mandamentos (GUTIÉRREZ, 1986, p. 131). Precisavam apresentar suas certidões de batismo, muitas vezes difíceis de serem oferecidas devido à mobilidade espacial da população, fazendo com que muitas vezes os nubentes estivessem distantes das freguesias onde foram batizados. Quando houvesse dificuldade em se apresentar a certidão de batismo, a mesma poderia ser mostrada posteriormente, ou o pároco que efetuou o sacramento poderia confirmá-lo, ou mesmo os padrinhos. Outra exigência era a dos proclamas, que deveriam ser tornados públicos durante três domingos ou dias santos seguidos, na freguesia onde se daria o casamento e em todas aquelas onde os noivos tinham residido desde a idade permitida para a participação no sacramento ${ }^{107}$. Como afirmou Silva (1984, p. 144), apesar dos entraves não terem sido percebidos apenas pelos escravos, a dificuldade "se fazia tanto mais sentir quanto menores eram as posses dos contraentes ou, no caso da escravatura, de seus senhores".

Por conseguinte, embora consideremos que o casamento foi uma experiência compartilhada por "poucos" cativos, é necessário o conhecimento de algumas características do mesmo. Desta forma, estudamos os perfis das famílias formadas a partir do matrimônio, como a freqüência de uniões entre escravos de mesmo senhor, a origem dos nubentes e o ambiente no qual as cerimônias foram realizadas.

Manoel Jordão da Silva Vargas, escravista citado em registros das freguesias de Mambucaba e da Ilha Grande, no ano de 1830 teve a sua escrava Claudina, de nação Guiné, batizada. Em 1834, a escrava uniu-se em matrimônio a João, também de nação.

\footnotetext{
${ }^{106}$ Ou seja, com outros escravos, forros ou livres.

${ }^{107}$ Silva (1984) citou casos em que a Igreja amenizou as exigências para a realização do matrimônio. Por exemplo, a Igreja na Capitania de São Paulo, em fins do século XVIII, abriu mão das provisões para os casamentos entre escravos.
} 
Deste matrimônio nasceu, em 18 de maio de 1835, Pocidônia, batizada no mesmo ano. No ano de 1837, o casal retornou à igreja a fim de batizar sua filha Justina ${ }^{108}$.

Claudina e João foram dois dos 448 cativos que tiveram seus registros de casamento localizados.

Constituindo 224 cerimônias realizadas entre 1830 e 1886, a freqüência de sacramentos oscilou entre nenhuma cerimônia, para 19 anos daquele período, e 29 casamentos, realizados no ano de $1854^{109}$. Em média, naquele intervalo de tempo, foram quatro cerimônias ao ano.

Os casamentos envolveram cativos de 56 proprietários, correspondendo a 4,3\% de um total de 1.312 escravistas cujos cativos compareceram às cerimônias, na qualidade de noivos, testemunhas, batizandos e pais, padrinhos e madrinhas.

Dos 56 proprietários, 25 (44,6\%) senhores tiveram apenas um casal de escravos que sacramentaram sua união, 14 (25,0\%) tiveram dois casais presentes e 17 (30,4\%), três ou mais. Ou seja, predominaram proprietários citados uma ou duas vezes em registros de casamentos, participando de apenas 53 (23,7\%) sacramentos, ao passo que 171 (76,3\%) cerimônias envolveram escravos cujos proprietários foram citados em três ou mais casamentos. Os dois senhores mais anotados foram Antônio José Nogueira e José Joaquim Guimarães.

O primeiro foi indicado em 31 casamentos realizados tanto em Mambucaba quanto na Ribeira, na década de 1850. Ele, segundo o Almanak Laemmert dos anos entre 1856 e 1864, era fabricante de aguardente e fazendeiro de café ${ }^{110}$. Ele teve três crianças escravas e cinco homens adultos batizados. No total, compareceram em cerimônias de batismo e de casamento, excluindo as crianças, 72 escravos, na qualidade de batizandos adultos, pais, padrinhos, madrinhas, noivos e testemunhas.

\footnotetext{
${ }^{108}$ Livro de batismos de escravos de Mambucaba, 1830-1871. Convento do Carmo, Angra dos Reis, RJ. ${ }^{109}$ Os casamentos estão distribuídos da seguinte forma: do ano de 1830 até 1886, em 19 anos, nenhuma cerimônia foi realizada; um sacramento ocorreu em cinco anos; dois, em sete anos; três, em três anos; quatro casamentos ocorreram em oito anos; cinco, em dois anos; seis sacramentos, em três anos; sete, em dois anos; oito casamentos, em quatro anos; nove sacramentos, em um ano; 24 casamentos, em dois anos; e 29 matrimônios, em um ano. Por hora, estamos trabalhando com a noção de cerimônias e não de registros. Certamente, o número de registros foi menor que o de sacramentos, visto que existiram anotações de casamento onde constaram mais de um casal. Esses casamentos foram chamados de "casamentos coletivos".
}

${ }^{110}$ Almanak Laemmert de 1856, 1858, 1860, 1862 e de 1864. 
O segundo proprietário foi mencionado em cerimônias entre os anos de 1860 e 1870, tanto em Mambucaba quanto na Ilha Grande. Segundo o Almanak Laemmert, entre 1860 e de 1870, José Joaquim Guimarães era fazendeiro e lavrador de café ${ }^{111}$. Seus escravos, Antônia crioula, e Eleutério de nação Moçambique, casados em 1852 na Ilha Grande ${ }^{112}$, foram um dos 30 casais que legitimaram suas uniões. Os escravos envolvidos nos sacramentos de batismo e de casamento somaram 220 cativos, excluindo as crianças.

Os dois senhores foram, possivelmente, médios ou grandes escravistas. Os cativos de suas propriedades tiveram maiores oportunidades em encontrar parceiros, podendo, caso desejassem e contassem com o apoio de seus senhores, oficializar suas uniões perante a Igreja ${ }^{113}$.

Dos 224 casamentos, em duas cerimônias não foram indicados os nomes dos proprietários de um dos noivos, correspondendo a 0,9\%. Em uma cerimônia, ou 0,4\%, os noivos pertenciam a senhores diferentes, caso ocorrido na Ribeira, em 1873, envolvendo Cândida crioula, escrava do Major José Francisco de Magalhães, e Manoel, também crioulo, cativo de Ana de Castro Torrenes ${ }^{114}$. Em 221 (98,7\%) sacramentos, os cônjuges pertenciam ao mesmo senhor.

Em Santana do Parnaíba, uma área dedicada ao mercado interno, Metcalf (1990) encontrou, entre 1775 e 1820, 94\% de casamentos envolvendo escravos pertencentes ao mesmo senhor, levando-a a afirmar que "é possível que senhores com poucos escravos tivessem desencorajando o casamento de seus cativos, fator que explicaria a escassez de matrimônio entre escravos de senhores diferentes” (METCALF, 1990, p. 206).

Em Campinas, área especializada na produção do café, Slenes (1987) observou, no ano de 1872: “com exceção de algumas poucas pessoas que eram casadas com libertos, todos os escravos casados na amostra tinham cônjuges que pertenciam ao mesmo senhor" (SLENES, 1987, p. 218).

\footnotetext{
${ }^{111}$ Almanak Laemmert, entre os anos pares de 1860 e 1870.

${ }^{112}$ Livro de casamentos de escravos da Ilha Grande, 1851-1875. Igreja de Jacuecanga, Angra dos Reis, RJ.

${ }^{113}$ Em Campinas, a frequiência de escravos que experimentaram o matrimônio elevava-se paralelamente ao aumento do número de cativos nas propriedades (SLENES, 1987).

${ }^{114}$ Livro de casamentos de escravos da Ribeira, 1851-1886. Convento do Carmo, Angra dos Reis, RJ.
} 
No Paraná, entre 1803-1806, as listas nominativas informaram que, em Castro, no Planalto, todos os 22 enlaces envolveram escravos de mesmo senhor (GUTIÉRREZ, 1986, p. 144).

Enfim, embora as Constituições determinassem que os escravos tinham liberdade de escolha de noivos, na prática eram postos limites à seleção de parceiros. Isto é, mesmo considerando a capacidade dos cativos de fazer reivindicações, de negociar, eram escravos e, portanto, a escolha de nubentes estava, em grande medida, restrita aos limites das propriedades em que viviam.

Permitir o casamento entre escravos de diferentes senhores causaria alguns problemas, como "residências diferentes, separação forçada, conflito sobre tratamento humano e direitos de propriedade” (SCWARTZ, 1995, p. 313). Característica diferente do que ocorreu nos Estados Unidos, onde os matrimônios envolvendo cativos de diferentes proprietários foram comuns (METCALF, 1990, p. 206).

Em Angra, entre os casais localizados apenas nos registros de batismos, as uniões entre cativos de mesmo senhor também foram predominantes, correspondendo a 456 $(98,1 \%)$ dos 465 casais. Dois $(0,4 \%)$ casais foram formados por cativos de senhores diferentes. Foi o caso, por exemplo, de Isabel crioula, escrava de Justino José de Carvalho Maia, e de seu marido Laurindo crioulo, cativo de Dona Teresa Gertrudes de Campos Alvim ${ }^{115}$. Enquanto isso, em sete (1,5\%) sacramentos de batismo, as mães eram escravas e seus maridos, forros ${ }^{116}$. Um destes casais foi formado por Deolinda Maia, escrava parda pertencente à Dona Maria Cândida Maia, e seu marido João Francisco Domingos, forro $^{117}$.

Existiam vantagens para os proprietários daquelas mulheres, como garantir a permanência da mão-de-obra forra junto a eles. Da mesma forma para os libertos, sendo um meio de ter acesso às terras dos senhores de suas cônjuges (FARIA, 1998, p. 317).

Schwartz (1995) encontrou 13 (21\%) casamentos envolvendo cativos e forros de um total de 63 cerimônias, na paróquia de Purificação, entre 1774-1788, no Recôncavo

\footnotetext{
115 O casal foi localizado no batismo de seu filho Martinho, em 1852, na Ilha Grande. Livro de batismos de escravos da Ilha Grande, 1847-1860. Igreja de Jacuecanga, Angra dos Reis, RJ.

${ }^{116}$ Dos sete casais, seis estiveram em registros de batismos da década de 1880 e apenas um, nos anos de 1820.

${ }^{117}$ O casal foi citado no batismo do filho, na Ilha Grande, em 1884. Livro de batismos de filhos de escravas da Ilha Grande, 1872-1888. Igreja de Jacuecanga, Angra dos Reis, RJ.
} 
Baiano. No caso, predominaram homens escravos e mulheres forras. O elevado número de homens nas propriedades com maior número de cativos, diminuía a oferta de noivas e fazia com que muitos se unissem às forras. Tal tendência tinha a "aprovação" de alguns senhores, obtendo daí "trabalhadoras que se tornariam ligadas às suas propriedades" (SCHWARTZ, 1995, p. 321).

Portanto, os casais que compareceram às cerimônias de batismos ou que foram localizados nos registros de casamentos de Angra dos Reis envolveram, em grande parte, escravos do mesmo senhor ${ }^{118}$.

TABELA 35

Freqüência de casamentos por subperíodos. Angra dos Reis, entre 1830 e 1886

\begin{tabular}{c|llr}
\hline Subperíodos & $\mathrm{n}^{\circ}$ & $\%$ & média anual \\
\hline $1830-1840$ & 39 & 17,4 & 3,5 \\
$1841-1851$ & 39 & 17,4 & 3,5 \\
$1852-1861$ & 111 & 49,6 & 11,1 \\
$1864-1873$ & 16 & 7,1 & 1,6 \\
$1874-1886$ & 19 & 8,5 & 1,4 \\
$1830-1886$ & 224 & 100,0 & 4,0 \\
\hline
\end{tabular}

FONTES: Livro de casamentos de escravos de Mambucaba, 1830-1875; Livro de casamentos de escravos da Ribeira, 1851-1886; e Livro de casamentos de escravos da Ilha Grande, 1851-1875. Convento do Carmo e Igreja de Jacuecanga, Angra dos Reis, RJ.

Nos dois primeiros subperíodos, as médias anuais foram de 3,5; entre 1852-1861 foram 11,1 casamentos, ao ano; e nos dois últimos intervalos, respectivamente, 1,6 e 1,4.

Os dados inicialmente nos levam a pensar que os casamentos foram predominantes na segunda metade do século XIX. Entretanto, o cruzamento entre registros de casamentos e de batismos mostrou que o movimento ascendente de matrimônios, ao longo do tempo ${ }^{119}$, não correspondeu ao aumento das famílias legitimadas pelo sacramento. Das 683 famílias legítimas, com ou sem filhos, localizadas nos registros de casamentos, de 1830 a 1886, e de batismos, de 1805 a 1888, 410 (60,0\%) foram encontradas entre 1805 e 1849, 224 (32,8\%) entre 1850 e 1871, e 49 (7,2\%) entre

\footnotetext{
${ }^{118}$ Como conseqüência, quanto maior a FTP, maior freqüência de casais unidos legalmente. Essa tendência foi verificada, também, nos inventários de Angra dos Reis.

${ }^{119}$ Na verdade, os dados existentes na tabela 35 referem-se apenas aos registros localizados. Ou seja, a maior parte dos registros disponíveis nos livros paroquiais correspondem a segunda metade do século XIX.
} 
1872 e $1888^{120}$. Ou seja, houve uma diminuição do percentual de indivíduos envolvidos em laços matrimoniais ${ }^{121}$.

A diminuição da participação de famílias legalizadas, encontrada em registros de batismos e de casamentos, na comparação entre 1805-1849, 1850-1871 e 1872-1888, resultou do aumento das dificuldades obtidas pelos cativos em estabelecer laços com escravos dos seus senhores. Tais dificuldades tornaram-se mais intensas à medida que avançava a segunda metade do século XIX, quando o número de escravos em Angra sofreu grande queda. A perda numérica representou a diminuição de cativos em muitas propriedades. Ao lado disso, o aumento percentual dos crioulos conformou uma escravaria constituída por indivíduos que se conheciam, e que tinham vínculos familiares, reduzindo ainda mais a oferta de possíveis cônjuges. Além do aumento das pequenas propriedades.

Ao senhor, por sua vez, não interessava que seus cativos legalizassem suas uniões, evitando assim a possível atuação da Igreja quando houvesse necessidade de vender um dos cônjuges.

A seguir, analisamos o ambiente no qual foram realizados os casamentos, ou seja, os locais, se ocorreram em conjunto com outros matrimônios, os meses e as horas. Tais informes permitem observar se, além de desaprovarem a união de seus escravos com cativos de outras propriedades, os senhores interferiam em outros aspectos relativos ao matrimônio.

\footnotetext{
${ }^{120}$ As famílias foram contadas quando de seu primeiro aparecimento. Por exemplo, se o primeiro batismo de um filho encontrado nesta pesquisa datava de 1830, o respectivo casal foi contado para primeira metade do século XIX.

${ }^{121}$ Trata-se da mesma conclusão encontrada no capítulo 4.
} 
TABELA 36

Freqüência de casamentos coletivos e simples por subperíodos. Angra dos Reis, 1830-1886

\begin{tabular}{|c|c|c|c|c|c|c|}
\hline \multirow[t]{2}{*}{ Subperíodos } & \multicolumn{2}{|c|}{ Simples } & \multicolumn{2}{|c|}{ Coletivo } & \multicolumn{2}{|c|}{ Total } \\
\hline & $n^{\circ}$ & $\%$ & $n^{\circ}$ & $\%$ & $\mathrm{n}^{\circ}$ & $\%$ \\
\hline $1830-1840$ & 24 & 61,5 & 15 & 38,5 & 39 & 100,0 \\
\hline 1841-1851 & 16 & 41,0 & 23 & 59,0 & 39 & 100,0 \\
\hline 1852-1861 & 23 & 20,7 & 88 & 79,3 & 111 & 100,0 \\
\hline 1864-1873 & 12 & 75,0 & 4 & 25,0 & 16 & 100,0 \\
\hline 1874-1886 & 10 & 52,6 & 9 & 47,4 & 19 & 100,0 \\
\hline 1830-1886 & 85 & 37,9 & 139 & 62,1 & 224 & 100,0 \\
\hline
\end{tabular}

FONTES: Livro de casamentos de escravos de Mambucaba, 1830-1875; Livro de casamentos de escravos da Ribeira, 1851-1886; e Livro de casamentos de escravos da Ilha Grande, 1851-1875. Convento do Carmo e Igreja de Jacuecanga, Angra dos Reis, RJ.

Entre os anos de 1830-1840, os casamentos simples foram mais comuns; no segundo e terceiro subperíodos predominaram os casamentos que envolviam mais de um casal; e nos dois últimos, os matrimônios simples se destacaram.

Em 62,1\% dos registros de casamentos, de 1830 a 1886, foram anotados em um único registro dois ou mais matrimônios, representando um predomínio de sacramentos coletivos.

Mas o que significaram casamentos realizados coletivamente? A definição da data para a realização da cerimônia possivelmente foi feita pelos senhores. Eles deveriam esperar a formação de um número mínimo de casais $^{122}$ que desejavam regularizar sua situação junto à Igreja. Se aqueles escravistas aguardavam a formação de um determinado número de casais, possivelmente deveriam ser detentores de médios ou grandes plantéis.

${ }^{122}$ Os casais já poderiam estar vivendo maritalmente, antes mesmo da cerimônia. 
TABELA 37

Locais das cerimônias de casamento por subperíodos. Angra dos Reis, 1830-1886

\begin{tabular}{|c|c|c|c|c|c|c|}
\hline \multirow[t]{2}{*}{ Subperíodos } & \multicolumn{2}{|c|}{ Igrejas } & \multicolumn{2}{|c|}{ Outros locais } & \multicolumn{2}{|c|}{ Total } \\
\hline & $n^{\circ}$ & $\%$ & $n^{\circ}$ & $\%$ & $n^{\circ}$ & $\%$ \\
\hline $1830-1840$ & 39 & 100,0 & 0 & & 39 & 100,0 \\
\hline 1841-1851 & 39 & 100,0 & 0 & & 39 & 100,0 \\
\hline $1852-1861$ & 47 & 44,0 & 60 & 56,0 & 107 & 100,0 \\
\hline 1864-1873 & 10 & 66,7 & 5 & 33,3 & 15 & 100,0 \\
\hline 1874-1886 & 13 & 68,4 & 6 & 31,6 & 19 & 100,0 \\
\hline 1830-1886 & 148 & 67,6 & 71 & 32,4 & 219 & 100,0 \\
\hline
\end{tabular}

FONTES: Livro de casamentos de escravos de Mambucaba, 1830-1875; Livro de casamentos de escravos da Ribeira, 1851-1886; e Livro de casamentos de escravos da Ilha Grande, 1851-1875. Convento do Carmo e Igreja de Jacuecanga, Angra dos Reis, RJ.

NOTA: As localidades não foram citadas em cinco cerimônias.

Dos 224 casamentos, 148 (67,6\%) foram realizados na Igreja Matriz existente nas freguesias de Mambucaba, da Ribeira e da Ilha Grande. Enquanto que 71 (32,4\%) matrimônios ocorreram em oratórios das fazendas e residências dos senhores dos noivos.

Entre 1830 e 1886, somente nos anos de 1852 a 1861 destacaram-se as cerimônias efetuadas em “outros locais”. Portanto, na maior parte das vezes, os enlaces ocorreram na Igreja.

O percentual de casamentos coletivos sofreu a influência dos registros da Ilha Grande e da Ribeira. Na primeira, 46 (59,7\%) e na segunda, 25 (50,0\%) matrimônios foram realizados em residências e fazendas dos proprietários. Por exemplo, o oratório da Fazenda Dois Rios, na Ilha Grande, foi o local onde ocorreram 39 casamentos; na fazenda de Antônio José Nogueira, na Ribeira, foram celebrados 25 matrimônios de escravos pertencentes a ele; e na Fazenda do Holandês, na Ilha Grande, foram realizados cinco sacramentos de escravos do mesmo senhor. Foram ministradas duas cerimônias em duas residências pertencentes aos proprietários dos noivos, também na Ilha Grande.

Cruzando os dados das tabelas 36 e 37 verificamos relativa correlação entre as variáveis coletividade e casamentos realizados em outros locais. Entre 1830 e 1861, à proporção que aumentava a freqüência de casamentos coletivos, elevava-se os percentuais de uniões realizadas em oratórios de fazendas e residências de proprietários. No intervalo entre 1852-1861, os casamentos coletivos chegaram a $79,3 \%$ e as cerimônias realizadas em outros locais representaram 56,0\% dos sacramentos. Nos 
períodos de 1852-1861 até 1864-1873, ambas variáveis diminuíram e, em seguida, tiveram movimentos diferentes, aumentando o percentual de casamentos coletivos e diminuindo os casamentos realizados fora da Igreja.

Podemos concluir que, em geral, os casamentos que envolveram duas ou mais uniões, tenderam a ocorrer nas residências dos proprietários dos noivos. Isso parece natural, pois evitava o deslocamento de grande número de cativos rumo a Igreja e, conseqüentemente, contratempos, como a fuga. Da mesma forma que criava um clima "festeiro" nos locais de trabalho dos escravos, além, evidentemente, de diminuir os dias perdidos de trabalho com cerimônias, pois se cada casal optasse por unir-se em dias diferentes, maior número de dias, ou horas, seriam desperdiçados.

TABELA 38

Horários das cerimônias de casamento por subperíodos. Angra dos Reis, 1830-1886

\begin{tabular}{|c|c|c|c|c|c|c|c|c|c|c|c|c|}
\hline \multirow[t]{2}{*}{ Horários } & \multicolumn{2}{|c|}{$1830-1840$} & \multicolumn{2}{|c|}{ 1841-1851 } & \multicolumn{2}{|c|}{$1852-1861$} & \multicolumn{2}{|c|}{ 1864-1873 } & \multicolumn{2}{|c|}{ 1874-1886 } & \multicolumn{2}{|c|}{$1830-1886$} \\
\hline & $n^{\circ}$ & $\%$ & $n^{\circ}$ & $\%$ & $n^{\circ}$ & $\%$ & $n^{\circ}$ & $\%$ & $\mathrm{n}^{\circ}$ & $\%$ & $\mathrm{n}^{\circ}$ & $\%$ \\
\hline $6: 00$ & 0 & & 0 & & 1 & 1,1 & 0 & & 1 & 5,3 & 2 & 1,0 \\
\hline 7:00 & 2 & 5,4 & 0 & & 0 & & 0 & & 0 & & 2 & 1,0 \\
\hline 8:00 & 7 & 18,9 & 1 & 2,9 & 1 & 1,1 & 0 & & 3 & 15,7 & 12 & 6,1 \\
\hline 9:00 & 4 & 10,8 & 6 & 17,1 & 4 & 4,3 & 2 & 18,2 & 2 & 10,5 & 18 & 9,2 \\
\hline $10: 00$ & 3 & 8,1 & 5 & 14,3 & 30 & 31,8 & 6 & 54,5 & 6 & 31,6 & 50 & 25,5 \\
\hline 11:00 & 0 & & 11 & 31,4 & 12 & 12,8 & 0 & & 5 & 26,3 & 28 & 14,3 \\
\hline $12: 00$ & 7 & 18,9 & 3 & 8,6 & 38 & 40,4 & 1 & 9,1 & 0 & & 49 & 25,0 \\
\hline $13: 00$ & 2 & 5,4 & 0 & & 0 & & 0 & & 0 & & 2 & 1,0 \\
\hline \multicolumn{13}{|l|}{ Subtotal } \\
\hline Manhã & 25 & 67,6 & 26 & 74,3 & 86 & 91,5 & 9 & 81,8 & 17 & 89,5 & 163 & 83,2 \\
\hline $14: 00$ & 1 & 2,7 & 2 & 5,7 & 0 & & 1 & 9,1 & 1 & 5,3 & 5 & 2,6 \\
\hline $15: 00$ & 0 & & 1 & 2,9 & 6 & 6,4 & 0 & & 1 & 5,3 & 8 & 4,1 \\
\hline $16: 00$ & 9 & 24,3 & 0 & & 1 & 1,1 & 0 & & 0 & & 10 & 5,1 \\
\hline $17: 00$ & 1 & 2,7 & 6 & 17,1 & 0 & & 0 & & 0 & & 7 & 3,6 \\
\hline $18: 00$ & 1 & 2,7 & 0 & & 1 & 1,1 & 1 & 9,1 & 0 & & 3 & 1,5 \\
\hline \multicolumn{13}{|l|}{ Subtotal } \\
\hline Tarde & 12 & 32,4 & 9 & 25,7 & 8 & 8,5 & 2 & 18,2 & 2 & 10,5 & 33 & 16,8 \\
\hline Total & 37 & 100,0 & 35 & 100,0 & 94 & 100,0 & 11 & 100,0 & 19 & 100,0 & 196 & 100,0 \\
\hline
\end{tabular}

FONTES: Livro de casamentos de escravos de Mambucaba, 1830-1875; Livro de casamentos de escravos da Ribeira, 1851-1886; e Livro de casamentos de escravos da Ilha Grande, 1851-1875. Convento do Carmo e Igreja de Jacuecanga, Angra dos Reis, RJ.

NOTA: Em 28 cerimônias não constavam informações acerca da hora.

De 1830 a 1886, 163 (83,2\%) sacramentos foram realizados na parte da manhã, entre as seis e às 13 horas. À tarde, entre as quatro e às 18 horas, foram efetuadas 33 (16,8\%) cerimônias.

O predomínio de sacramentos ocorridos durante a manhã foi comum em todos os anos. 
Quando as cerimônias eram realizadas em horário matutino, noivos e convidados aproveitavam a luz do sol e o dia para a realização de festividades, que deveria ser comum aos casamentos realizados nas fazendas, ou garantir o retorno de todos, quando a igreja era distante da residência dos senhores.

TABELA 39

Sazonalidade das cerimônias de casamentos por subperíodos. Angra dos Reis, 1830-1886

\begin{tabular}{|c|c|c|c|c|c|c|c|c|c|c|c|c|}
\hline \multirow[t]{2}{*}{ Mês } & \multicolumn{2}{|c|}{$1830-1840$} & \multicolumn{2}{|c|}{ 1841-1851 } & \multicolumn{2}{|c|}{ 1852-1861 } & \multicolumn{2}{|c|}{ 1864-1873 } & \multicolumn{2}{|c|}{ 1874-1886 } & \multicolumn{2}{|c|}{ 1830-1886 } \\
\hline & $\mathrm{n}^{\circ}$ & $\%$ & $\mathrm{n}^{\circ}$ & $\%$ & $\mathrm{n}^{\circ}$ & $\%$ & $n^{\circ}$ & $\%$ & $\mathrm{n}^{\circ}$ & $\%$ & $\mathrm{n}^{\circ}$ & $\%$ \\
\hline Janeiro & 2 & 5,1 & 5 & 15,6 & 3 & 15,0 & 0 & & 0 & & 10 & 10,7 \\
\hline Fevereiro & 2 & 5,1 & 5 & 15,6 & 1 & 5,0 & 0 & & 0 & & 8 & 8,5 \\
\hline Março & 1 & 2,6 & 0 & & 0 & & 0 & & 0 & & 1 & 1,1 \\
\hline Abril & 2 & 5,1 & 0 & & 2 & 10,0 & 0 & & 0 & & 4 & 4,3 \\
\hline Maio & 4 & 10,3 & 1 & 3,1 & 0 & & 0 & & 0 & & 5 & 5,4 \\
\hline $\begin{array}{c}\text { Junho } \\
1^{\circ}\end{array}$ & 6 & 15,4 & 9 & 28,1 & 1 & 5,0 & 1 & 100,0 & 0 & & 17 & 18,3 \\
\hline semestre & 17 & 43,6 & 20 & 62,5 & 7 & 35,0 & 1 & 100,0 & 0 & & 45 & 48,4 \\
\hline Julho & 2 & 5,1 & 6 & 18,8 & 0 & & 0 & & 0 & & 8 & 8,6 \\
\hline Agosto & 3 & 7,7 & 0 & & 2 & 10,0 & 0 & & 0 & & 5 & 5,4 \\
\hline Setembro & 3 & 7,7 & 2 & 6,3 & 11 & 55,0 & 0 & & 1 & 100,0 & 17 & 18,3 \\
\hline Outubro & 8 & 20,5 & 0 & & 0 & & 0 & & 0 & & 8 & 8,6 \\
\hline Novembro & 5 & 12,8 & 4 & 12,5 & 0 & & 0 & & 0 & & 9 & 9,7 \\
\hline $\begin{array}{c}\text { Dezembro } \\
2^{\circ}\end{array}$ & 1 & 2,6 & 0 & & 0 & & 0 & & 0 & & 1 & 1,1 \\
\hline semestre & 22 & 56,4 & 12 & 37,5 & 13 & 65,0 & 0 & & 1 & 100,0 & 48 & 51,6 \\
\hline Total & 39 & 100,0 & 32 & 100,0 & 20 & 100,0 & 1 & 100,0 & 1 & 100,0 & 93 & 100,0 \\
\hline
\end{tabular}

FONTES: Livro de casamentos de escravos de Mambucaba, 1830-1875; Livro de casamentos de escravos da Ribeira, 1851-1886; e Livro de casamentos de escravos da Ilha Grande, 1851-1875. Convento do Carmo e Igreja de Jacuecanga, Angra dos Reis, RJ.

NOTA: Em 131 cerimônias não havia informações a respeito do mês.

Os noivos casavam, por vezes, no primeiro semestre e, em outras ocasiões, no segundo. Na verdade não houve preferência quanto aos semestres.

No entanto, podemos dizer que os meses do calendário religioso dedicados à penitência, como o Advento e a Quaresma, foram evitados ${ }^{123}$ : no mês de dezembro, entre 1830 e 1886, ocorreu um (1,1\%) casamento e no mês de março foi realizado apenas um matrimônio (1,1\%).

A ligação entre meses do casamento e o calendário religioso foi observada por Marcílio (1986, p. 191) quando analisou os matrimônios de escravos, de 1810 a 1819, e de livres, entre 1800 e 1834, em Ubatuba. Bacellar (2001, p. 80), estudando os

\footnotetext{
${ }^{123}$ O Advento correspondia às três semanas antes do Natal e a Quaresma, quarenta dias antes da Páscoa. Ver, por exemplo, o estudo sobre Ubatuba, realizado por Marcílio (1986, p. 191).
} 
casamentos de livres em Sorocaba, entre 1679 e 1830, também constatou respeito ao calendário religioso e uma tendência, ao longo dos anos, de diminuição da rejeição quanto ao Advento.

Os casamentos sofriam a influência também do calendário agrícola local. Marcílio (1986), em pesquisa sobre Ubatuba, considerou que os meses mais intensos para a lavoura de subsistência — milho, mandioca, feijão e arroz — eram agosto, mês de plantação, e maio e junho, meses dedicados às queimadas e "eventuais derrubadas das matas para abertura de novas roças” (MARCÍLIO, 1986, p. 191). Os meses de janeiro, este de muitas chuvas, mas de colheita do milho e de amadurecimento de várias frutas, até abril, e de setembro até o fim do ano, eram meses onde o ritmo de trabalho era menor.

Considerando Ubatuba uma localidade próxima ao litoral sul-fluminense, com um clima semelhante ao de Angra e com uma população que se dedicava aos mesmos cultivos que a angrense, o calendário oferecido pela autora é passível de ser empregado para a área em estudo.

Retornando à tabela, os meses de junho e de setembro foram os mais requisitados, respectivamente, com 17 (18,3\%) e 17 (18,3\%). O primeiro, referente ao período de muito trabalho agrícola e o segundo, quando diminuía o ritmo de trabalho. Portanto, houve relativa correlação entre o calendário agrícola e os meses mais preferidos para a realização dos casamentos.

Finalmente, baseando-nos nos informes vistos até agora, concluímos que, embora a Igreja afirmasse que os senhores não poderiam intervir no casamento de seus escravos, àqueles acabavam impondo limites às cerimônias, como a resistência aos matrimônios entre escravos de diferentes senhores. Os escravos envolvidos com cativos da mesma propriedade tinham maiores chances de sacramentarem suas uniões, caso desejassem. O mesmo não ocorria quando o parceiro pertencia a outro senhor. Neste caso, a união estaria fadada a não receber a benção da Igreja, estando também mais vulnerável a obstáculos, como migração de um dos senhores e seus escravos e encontros menos freqüentes.

Ao longo dos anos, as dificuldades para a oficialização das uniões tornaram-se mais visíveis, aumentando o percentual de famílias formadas, aos olhos da Igreja, por mães solteiras e seus filhos. Recorrendo aos registros de batismo e de casamento 
encontramos, entre 1805-1849, 866 (67,9\%) famílias formadas por mães solteiras e seus filhos e 410 (32,1\%), constituídas por casais unidos legalmente, com ou sem filhos. Entre 1850-1871 foram, respectivamente, 820 (78,5\%) e 224 (21,5\%) e, entre 1872-1888, 226 (82,2\%) famílias cujos filhos eram naturais e 49 (17,8\%) famílias legitimadas pelo casamento.

Num quadro de crise local, de perda da mão-de-obra e de aumento de pequenas propriedades, o casamento escravo tornou-se uma experiência vivida por poucos.

Ao mesmo tempo, a atuação do escravista não foi observada apenas quanto à escolha dos cônjuges. Delimitações como local onde se daria a cerimônia, o dia e a hora, resultaram, embora não de forma absoluta, da interferência senhorial.

A definição do local da cerimônia determinava o deslocamento ou não dos cativos, podendo tornar possível, por exemplo, a fuga, se não dos noivos, ao menos de escravos que fossem participar da cerimônia, bem como o tempo que seria perdido no trajeto, tempo a menos para a realização das atividades cotidianas. Este aspecto traz a questão do dia em que seria realizada a cerimônia, podendo receber, relativamente, a influência senhorial, perceptível em matrimônios realizados coletivamente,

"registros de casamento que documentam em uma mesma cerimônia a união de três ou quatro casais escravos pertencentes a um mesmo senhor parecem indicar a intervenção direta do proprietário na seleção e na época dos casamentos” (SCWARTZ, 1995, p. 315).

Reunir vários casais a fim de sacramentar suas uniões num único dia foi um meio de garantir menor perda de dias de trabalho. Indicava também a convivência dos nubentes antes mesmo da oficialização do matrimônio. O cativo esperaria uma data que fosse compatível para se unir, efetivamente, ao seu parceiro? Pouco provável. Além do mais, existiram casamentos em Angra antecedidos por nascimento de filhos naturais que, por certo, resultaram do encontro carnal do casal que, posteriormente, veio a legalizar sua união $^{124}$. O horário também foi, em parte, definido por seus senhores, com predomínio de

\footnotetext{
${ }^{124}$ Slenes (1999, p. 103) verificou em Campinas, em 1872, que nas propriedades com até quatro escravos e entre cinco e nove cativos, cinco, de seis mulheres citadas como casadas ou viúvas, começaram suas vidas reprodutivas como solteiras. No caso das mulheres com aquelas condições conjugais presentes nas propriedades com 10 ou mais escravos, a matrícula de 1872 indicou que seus primeiros filhos foram legítimos. Entretanto, deveriam ser, de fato, naturais.
} 
sacramentos ministrados na parte da manhã, além da preocupação em se respeitar o calendário religioso.

Ainda que houvesse a atuação e o controle senhorial sobre alguns dos aspectos concernentes ao casamento escravo, havia um específico (apesar de também poder receber a tal influência senhorial) que resultava das escolhas dos cativos, como, por exemplo, a seleção dos parceiros quanto à origem.

Segundo Slenes (1999), embora os senhores pudessem "sugerir, persuadir, pressionar e finalmente aprovar ou vetar os nomes escolhidos” (SLENES, 1999, p. 94) pelos cativos, caberia a estes últimos a seleção. Entretanto, não significa que não houvesse uniões “impostas” pelos proprietários, mas também seria pouco provável que uniões formadas a partir de uma intervenção direta pudessem resistir ao tempo.

A atuação senhorial era permanente sobre a vida dos escravos. Não obstante, existiram possibilidades dos cativos explicitarem suas opiniões, suas vontades; quer optando pela união consensual, com cativo de outra propriedade e respondendo, assim, pelo ônus que isso pudesse causar; quer unindo-se ao seu parceiro antes mesmo da oficialização da união, ou associando-se a forros e livres. Concordamos com as palavras de Faria (1998): "pode-se considerar que, mesmo no embate pessoal, inúmeras vezes os senhores tiveram que anuir aos desejos de seus escravos, como estratégias de dominação" (FARIA, 1998, p. 322). 
TABELA 40

Origens dos noivos por subperíodos. Angra dos Reis, entre os anos de 1830 e 1886

\begin{tabular}{|c|c|c|c|c|c|c|c|c|c|c|c|c|}
\hline \multirow[t]{2}{*}{ HOxMU } & \multicolumn{2}{|c|}{$1830-1840$} & \multicolumn{2}{|c|}{$1841-1851$} & \multicolumn{2}{|c|}{$1852-1861$} & \multicolumn{2}{|c|}{ 1864-1873 } & \multicolumn{2}{|c|}{ 1874-1886 } & \multicolumn{2}{|c|}{ 1830-1886 } \\
\hline & $n^{\circ}$ & $\%$ & $\mathrm{n}^{\circ}$ & $\%$ & $n^{\circ}$ & $\%$ & $n^{\circ}$ & $\%$ & $n^{\circ}$ & $\%$ & $\mathrm{n}^{\circ}$ & $\%$ \\
\hline AxA & 27 & 75,0 & 16 & 51,6 & 52 & 58,4 & 1 & 11,1 & 0 & & 96 & 53,0 \\
\hline $\mathrm{CxC}$ & 3 & 8,3 & 10 & 32,3 & 11 & 12,3 & 7 & 77,7 & 9 & 56,2 & 40 & 22,1 \\
\hline Subtotal & & & & & & & & & & & & \\
\hline Endogamia & 30 & 83,3 & 26 & 83,9 & 63 & 70,8 & 8 & 88,9 & 9 & 56,2 & 136 & 75,1 \\
\hline $\mathrm{AxC}$ & 1 & 2,8 & 3 & 9,7 & 23 & 25,8 & 0 & & 6 & 37,5 & 33 & 18,2 \\
\hline CxA & 5 & 13,8 & 2 & 6,4 & 3 & 3,4 & 1 & 11,1 & 1 & 6,2 & 12 & 6,6 \\
\hline Subtotal & & & & & & & & & & & & \\
\hline Exogamia & 6 & 16,7 & 5 & 16,1 & 26 & 29,2 & 1 & 11,1 & 7 & 43,8 & 45 & 24,9 \\
\hline Total & 36 & 100,0 & 31 & 100,0 & 89 & 100,0 & 9 & 100,0 & 16 & 100,0 & 181 & 100,0 \\
\hline
\end{tabular}

FONTES: Livro de casamentos de escravos de Mambucaba, 1830-1875; Livro de casamentos de escravos da Ribeira, 1851-1886; e Livro de casamentos de escravos da Ilha Grande, 1851-1875. Convento do Carmo e Igreja de Jacuecanga, Angra dos Reis, RJ.

NOTAS: $\mathrm{HO}=$ homem; $\mathrm{MU}=$ mulher; $\mathrm{A}=$ africano; $\mathrm{C}=$ crioulo. Em 43 cerimônias um ou ambos cônjuges não tiveram suas origens indicadas.

Nos anos entre 1830 e 1886, a maior parte dos casamentos envolveu cônjuges de mesma origem, representando 136 matrimônios, ou 75,1\%. Destes, 96 (53,0\%) abrangeram africanos e 40 (22,1\%) sacramentos tiveram noivos nascidos no Brasil. Os casamentos entre cativos de diferentes origens somaram 45, correspondendo a $24,9 \%$.

Em todos os subperíodos, os noivos de igual origem foram a maioria. No entanto, de 1830 até 1861, a endogamia africana foi predominante. Entre 1864 e 1886 os cônjuges crioulos se destacaram.

A crioulização dos noivos esteve associada ao processo demográfico visto nos capítulos anteriores, caracterizado pelo aumento do percentual de cativos nascidos no Brasil. Isto resultava tanto dos nascimentos realizados em Angra quanto do distanciamento do fim do tráfico de africanos, em 1850.

Entre os casais que batizaram seus filhos ao longo do século XIX, mas que não foram citados nos registros de casamentos, observamos que ${ }^{125}$ : a endogamia predominou, chegando, entre 1805 e 1888, a 217 (66,8\%), destacando-se as uniões entre africanos. Casais de diferentes origens somaram 108 (33,2\%), com representatividade de homens africanos e esposas crioulas.

\footnotetext{
125 Para a organização dos informes foram contados uma única vez os casais que levaram seus filhos ao batismo. Se um determinado casal foi citado, pela primeira vez, em 1850, incluímos a família no subperíodo de 1850-1888.
} 
Já entre os casais presentes nos inventários, mas que não foram citados nos registros paroquiais, constatamos o predomínio da endogamia, em particular, a africana. Contudo, houve uma redução percentual daqueles casais, após 1850. Entre 1800 e 1848, 25 (78,1\%) cônjuges eram de igual origem, contra sete (21,9\%) uniões exogâmicas. Entre 1849 e 1888, encontramos, respectivamente, 11 (61,1\%) e sete (38,9\%).

Comparando os dados presentes na tabela 40, para os anos entre 1805 e 1849 e de 1850 a 1886, notamos que os percentuais de casais com a mesma origem reduziram-se, correspondendo a 70,1\% e 54,7\%, respectivamente. O movimento representou a diminuição da participação percentual dos casais africanos, embora ainda estivessem em destaque no segundo subperíodo, e o aumento percentual dos crioulos. Os casais de diferentes origens elevaram sua participação, passando de 29,9\% à 45,3\%, respectivamente. Este aumento percentual esteve vinculado à presença de homens africanos e suas esposas crioulas.

Com os anos, a perda numérica de africanos, dentre os cativos de Angra, e a elevação percentual dos crioulos fizeram com que diferenças, como rixas entre africanos e crioulos, diminuíssem. Após 1872, quando a participação de africanos reduziu-se ainda mais, caminhou-se para uma elevação da endogamia, representando $75 \%$ dos casais. Agora, ambos cônjuges nascidos no Brasil representaram a maioria dos pares endogâmicos, ou $68,8 \%{ }^{126}$.

Portanto, a análise das origens de maridos e esposas está vinculada à demografia. Ou seja, o aumento percentual de crioulos entre os escravos e a chegada de muitos deles às idades de 12 e 14 anos tornava-os potencialmente cônjuges. Num determinado momento, talvez nos anos próximos a 1850, quando a localidade ainda possuía africanos em idade adulta, estes tenderam a se fechar. A segunda alternativa encontrada pelos africanos foi a união com crioulos. Posteriormente, já na década de 1870, quando os africanos tinham idades elevadas e a elevou-se a representatividade de crioulos, destacouse a endogamia entre os cativos nascidos no Brasil.

Porém, tanto nos registros de casamento quanto nos de batismo ${ }^{127}$, a endogamia foi predominante, isto é, os cativos, quando buscaram seus parceiros, escolhiam aqueles

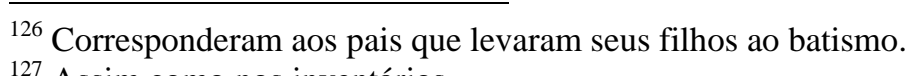

${ }^{127}$ Assim como nos inventários. 
que thes eram "iguais" na origem. Logo, crioulos convidavam crioulos e africanos selecionavam africanos.

A endogamia foi vista para outras regiões, como na Paróquia da Purificação, no Recôncavo Baiano, entre 1774-1788, quando havia, além de uma tendência endogâmica a partir da origem, também no referente à procedência ${ }^{128}$; embora "quaisquer que fossem os padrões de preferência que marcaram os vários povos africanos, maiores ainda eram as barreiras entre africanos e crioulos" (SCHWARTZ, 1995, p. 320). Na freguesia urbana de São José, no Rio de Janeiro, entre 1802-1821, casamentos endogâmicos corresponderam a 74,57\% (FERREIRA, 2000, p. 155) e foram comuns também no agro fluminense, entre 1790 e 1830 (GÓES, 1998, p. 310). Ainda no agro fluminense, no ano de 1860, a endogamia respondeu por 60,00\% (SIMONATO, 1998, p. 169). Em Mariana, Minas Gerais, entre 1750-1850, casais de igual origem representaram 50,50\% (ALMEIDA, 1998, p. 254). Em Bananal no ano de 1801, 76,40\% dos casais foram formados por escravos de mesma origem (MOTTA, 1999a, p. 261-262).

A exogamia, por sua vez, caracterizou-se, predominantemente, por homens africanos e mulheres crioulas. Esta constatação foi vista também no agro fluminense, em 1860 (SIMONATO, 1998, p. 168); para São José, freguesia da cidade do Rio de Janeiro, entre 1802-1822 (FERREIRA, 2000, p. 155); e para Lorena, em São Paulo, no ano de 1801 , onde $24,7 \%$ dos casais foram formados por homens africanos e esposas crioulas (COSTA, SLENES \& SCHWARTZ, 1987, p. 288).

Comparando as ocasiões, entre 1830 e 1886, em que homens e mulheres de diferentes origens foram citados nos registros de casamento, notamos que os homens africanos compareceram 129 vezes ao sacramento, ou 35,6\%, e os crioulos estiveram em 52 (14,4\%). As noivas africanas apresentaram-se em 108 (29,8\%) matrimônios e as crioulas, em $73(20,2 \%)^{129}$.

Os africanos estiveram presentes no sacramento do casamento, talvez porque tenham sido a origem mais comum de grande parte dos escravos em idade adulta, ao menos até meados do século XIX.

\footnotetext{
${ }^{128}$ A origem está relacionada ao local de nascimento, o Brasil ou a África. A procedência, à região de nascimento, etnia ou local de embarque, por exemplo, Angola, Mina, etc.

${ }^{129}$ A origem não foi identificada para 86 noivos.
} 
Entretanto, na passagem da primeira para a segunda metade dos oitocentos, os africanos foram sendo substituídos pelos crioulos (ver tabela 40). A partir de 1864, homens e mulheres nascidos no Brasil representava a maior parte dos noivos pois, após 1850, a escravaria local foi-se caracterizando pela "crioulização” e estes cativos, na fase adulta, substituíram os de "além-mar".

Portanto, a análise dos registros de casamento ofereceu uma visão das condições em que se deram os sacramentos. Foi um evento no qual participou um número reduzido de cativos, pertencentes a 4,3\% do total de escravistas localizados nos registros paroquiais.

Os casamentos foram realizados, na maior parte das vezes, na Igreja Matriz das freguesias, em cerimônias, predominantemente, coletivas e no turno da manhã.

Na comparação entre os subperíodos, a tendência às cerimônias realizadas nas Igrejas se manteve, embora tenham existido sacramentos ministrados em oratórios e capelas de fazendas. As cerimônias coletivas foram predominantes e os horários matutinos, os mais comuns.

Estes informes demonstram uma relativa atuação senhorial sobre os casamentos, tanto na delimitação do local e hora, quanto na necessidade de aguardar um determinado número de noivos para efetivar as uniões. Isto se deve ao fato de que, por mais que houvesse a interferência dos cativos, reivindicando dia e hora, a decisão final ficava a cargo de seus proprietários, pois representava a perda de horas e dias de trabalho. Além do mais, optar por uniões coletivas servia para criar um clima de festa e de harmonia entre os escravos (cf. SLENES, 1999).

A interferência senhorial foi observada na quase ausência de casamentos entre escravos de diferentes donos, deixando claro que a liberdade que era dada aos escravos para a seleção de noivos, conforme informam a Constituições Primeiras, não se fez presente, na prática.

Quanto ao critério origem, observamos a predominância dos casais endogâmicos, envolvendo, em particular, os africanos, até 1850. Por outro lado, ocorreu um aumento percentual de uniões exogâmicas, apoiadas, principalmente, por homens africanos e mulheres crioulas. Caminhou-se, na segunda parte dos oitocentos, para a elevação percentual da endogamia, com a participação dos crioulos. 
À margem disso, verificamos, mediante registros de batismos e de casamentos, uma redução de famílias legitimadas pelo matrimônio. Isto associou-se a um projeto senhorial que visava evitar a intervenção da Igreja em seu relacionamento com seus escravos. Intervenção que poderia ser acionada, por exemplo, quando o escravista optasse por vender um de seus escravos casados, prática censurada pela Igreja. Tal preocupação tornou-se mais intensa após 1850, num período de crise econômica e de promulgação da Lei de 1869, que proibia a separação por venda de escravos casados e a separação de uma mãe ou de um pai de seus filhos menores de 15 anos, idade reduzida a 12 anos, em 1872 (SLENES, 1999, p. 105).

Ao longo da segunda metade do século XIX, a grande diminuição de escravos, significando redução de cativos nas propriedades, e a "crioulização", formaram uma escravaria constituída por indivíduos que se conheciam, limitando a possibilidade de localização de parceiros entre os escravos de seus donos. Em contrapartida, houve a ampliação da ilegitimidade e de famílias formadas por mães solteiras e seus filhos.

Que tal nas próximas linhas, aprofundarmos os conhecimentos sobre as mães escravas, suas atitudes diante da concepção e da maternidade? 


\section{CAPÍTULO 6-MÃES CASADAS E MÃES SOLTEIRAS}

Generosa, de nação, escrava de Pedro Jordão da Silva Vargas, levou, em 1830, seu filho "natural” Roque, nascido a 27 de outubro do mesmo ano, ao batismo, em Mambucaba ${ }^{130}$.

Muitas foram as mães que, como Generosa, compareceram ao sacramento do batismo na qualidade de mulheres identificadas nos registros como “solteiras”, mães de crianças de "pais incógnitos”, ou mães de crianças “naturais” ${ }^{131}$.

\section{TABELA 41}

Origens das mães solteiras de crianças escravas e ingênuas batizadas por subperíodos. Angra dos Reis, 1805-1888

\begin{tabular}{c|c|c|c}
\hline Subperíodos & $\begin{array}{c}\text { Africanas } \\
\mathrm{n}^{\circ}(\%)\end{array}$ & $\begin{array}{c}\text { Crioulas } \\
\mathrm{n}^{\circ}(\%)\end{array}$ & $\begin{array}{c}\text { Total } \\
\mathrm{n}^{\circ}(\%\end{array}$ \\
\hline $1805-1815$ & $54(62,8)$ & $32(37,2)$ & $86(100,0)$ \\
$1816-1826$ & $163(68,2)$ & $76(31,8)$ & $239(100,0)$ \\
$1827-1837$ & $179(78,5)$ & $49(21,5)$ & $228(100,0)$ \\
$1838-1848$ & $91(65,9)$ & $47(34,1)$ & $138(100,0)$ \\
$1849-1859$ & $186(38,4)$ & $298(61,6)$ & $484(100,0)$ \\
$1860-1871$ & $41(24,7)$ & $125(75,3)$ & $166(100,0)$ \\
$1872-1888$ & $2(1,0)$ & $201(99,0)$ & $203(100,0)$ \\
$1805-1888$ & $716(46,4)$ & $828(53,6)$ & $1544(100,0)$ \\
\hline
\end{tabular}

FONTES: Livros de batismos de escravos da Ilha Grande de 1805-1847 e de 1850-1861; livro de batismos de ingênuos da Ilha Grande de 1872-1888; Livro de batismos de escravos de Mambucaba, 1830-1871; Livro de batismos de escravos da Ribeira, de 1824-1826; Livro de batismos, de casamentos e de óbitos de escravos e de livres de Jacuecanga, 1800-1888. Convento do Carmo e Igreja de Jacuecanga, Angra dos Reis, RJ.

NOTA: Não foram contabilizadas 353 mães pois os vigários não informaram suas origens.

Entre 1805 e 1888, as mães solteiras nascidas no Brasil representaram 828 (53,6\%). As africanas, por sua vez, corresponderam a $716(46,4 \%)$.

As mães africanas predominaram até 1848 e, em seguida, os percentuais de crioulas aumentaram ${ }^{132}$.

\footnotetext{
${ }^{130}$ Livro de batismos de escravos de Mambucaba, 1830-1859. Convento do Carmo. Angra dos Reis, RJ. ${ }^{131}$ No livro de batismos de ingênuos da Ilha Grande as mães de crianças ilegítimas foram definidas, muitas vezes, como solteiras. No livro de batismos de escravos da citada freguesia, de 1805-1830, e no livro relativo a Jacuecanga, os filhos ilegítimos foram chamados de filhos de "pais incógnitos". No livro de batismos de escravos de Mambucaba, de 1830-1859, e da Ribeira, de 1824-1826, aquelas crianças foram citadas como "naturais".

${ }^{132}$ Calculando as mães encontradas apenas nos inventários, localizamos: entre 1800-1848, 41 (48,8\%) eram africanas e 43 (51,2\%), mulheres nascidas no Brasil. De 1849 até 1888, os números foram, respectivamente, $30(28,6 \%)$ e $75(71,4 \%)$.
} 
Logo, podemos afirmar que a "crioulização” da população escrava, intensificada na segunda metade do século XIX, promoveu uma elevação numérica de mulheres daquela origem, aumentando, portanto, a participação das mesmas entre as mães solteiras. Não por menos, cresceu a freqüência de homens e mulheres crioulos em cerimônias de casamento, após 1864.

Mulheres definidas como mães solteiras não significava na prática mulheres sem parceiros. Pelo contrário, aquela definição traduzia somente que não eram casadas perante a Igreja, mas poderiam estar participando de uniões consensuais duráveis. Seus filhos poderiam, por exemplo, ter seus pais pertencentes a outros senhores, o que, como já foi visto, criava um entrave à legalização da união do casal. Dentre as mães solteiras havia também aquelas que participaram de uniões fortuitas ou acidentais, envolvendo, por exemplo, seus senhores.

O caso do escravista Antônio de Souza Lima ${ }^{133}$, da Ilha Grande, levanta algumas idéias. Ele foi citado em quatro registros como proprietário de Benedita, crioula parda, e de seus filhos. Benedita compareceu ao batismo, em 1850, do filho Ambrosio, nascido em 5 de dezembro do mesmo ano. Em 1851, seu filho Joaquim, nascido em 17 de dezembro daquele ano, foi convertido à fé cristã. Em 1852 foi a vez de Jacinto, nascido a 3 de julho de 1849. Em 1853 foi batizado Amâncio, nascido em 8 de abril do mesmo ano.

$\mathrm{O}$ fato de ter tido apenas um escravo adulto, Benedita, citado nos registros ${ }^{134}$, apesar de não poder ser uma prova de que Antônio de Souza Lima era proprietário de um só escravo; ao menos serve como uma estimativa de que não era médio e muito menos grande escravista. Isto deixa em aberto a idéia de que Benedita não deveria ter, na propriedade em que vivia, muitas possibilidades de escolha de possíveis parceiros. Desta forma, seus filhos deveriam ter como pai, ou um escravo pertencente a outra propriedade, dificultando qualquer possibilidade de regularização da união, ou um forro, ou um livre.

A frequiência com que Benedita teve seus filhos pode ser um indício de que ela estava inserida num relacionamento estável. Ela pariu, no mínimo, quatro crianças e elas nasceram em intervalos de um ano e cinco meses, entre o primeiro e o segundo filho; de

\footnotetext{
${ }^{133}$ Segundo o Almanak Laemmert, nas edições de 1856 a 1885, ele era proprietário, fazendeiro e lavrador de café, na Ilha Grande.

${ }^{134}$ Verificamos os demais pais dos batizandos, padrinhos, madrinhas, nos registros de batismo; e noivos e testemunhas, nos registros de casamentos.
} 
um ano, entre o segundo e o terceiro; e de um ano e quatro meses, entre o terceiro e o quarto filho. Ou seja, intervalos semelhantes.

O que pretendemos destacar no caso citado é que as escravarias pequenas dificultaram a formação de casais unidos perante a Igreja. Daí o aparecimento de mães solteiras, mulheres que tinham seus parceiros ou fixos, que poderiam ser escravos pertencentes a outras propriedades, ou forros, ou livres; ou mesmo, mulheres que tiveram seus filhos após encontros acidentais.

Das mães solteiras contadas, 61 (3,9\%) conseguiram casar após ter filhos naturais. Foram $30(51,7 \%)$ africanas e $28(48,3 \%)$ crioulas $^{135}$. Isto é, a grande maioria das mulheres permaneceu solteira.

Destas mulheres, 46 (75,4\%) pariram apenas um filho ilegítimo; 12 (19,7\%) tiveram dois filhos; e três $(4,9 \%)$ tiveram três filhos naturais. Os números de filhos correspondem, na verdade, àquelas crianças que sobreviveram e das quais conseguimos localizar seus registros de batismos. Isto significa que correspondem ao número mínimo de filhos nascidos antes do casamento de suas mães.

Conseqüentemente, à medida que o percentual de famílias legitimadas pelo casamento decrescia, as mães solteiras com seus filhos foram se tornando mais comuns em Angra dos Reis. Entre 1805-1848, muitas foram de origem africana. Nos anos de 1849-1888 predominaram as mães nascidas no Brasil. Algumas poucas escravas, entre africanas e crioulas, conseguiram casar após terem tido, geralmente, um filho natural.

Enfim, a maternidade foi um caminho encontrado para a conformação do perfil típico das famílias escravas de Angra, aquelas encabeçadas por mulheres, aparentemente, solteiras. Da mesma forma, a procriação também antecedeu a legalização da união de dois escravos, podendo, até mesmo, favorecê-la.

Hoje muitos estudos vêm abordando o tema, geralmente sob o prisma da reprodução natural. Tratam-se de análises que abordam o tema de forma a demonstrar a existência e a viabilidade da reprodução, garantindo a mão-de-obra escrava em áreas que não possuíam uma ligação direta com o mercado externo ${ }^{136}$.

\footnotetext{
${ }^{135}$ Houve três mães solteiras com origens desconhecidas que casaram.

${ }^{136}$ Cf. Paiva (1996); Paiva \& Libby (1995); Paiva \& Klein (1992).
} 
Conjugando reprodução e famílias escravas, apontamos, entre outros, o estudo sobre Magé, no estado do Rio de Janeiro, entre 1850-1888. Segundo Sampaio (1994) a população escrava crioula caracterizou-se pelo equilíbrio entre os sexos e por um percentual considerável de crianças. Tais dados, além do crescimento numérico dos escravos, levaram o autor a afirmar que a reprodução natural foi um importante meio de manutenção e, até mesmo, de ampliação da escravaria. Reprodução que, segundo ele, passava, principalmente, pela família escrava formada por mães solteiras e seus filhos.

Botelho (1994), em sua pesquisa sobre Montes Claros, no norte de Minas Gerais, entre 1810 e 1888, localizou entre os crioulos, um equilíbrio entre as faixas etárias e entre os sexos. Ambos seriam indícios de reprodução natural, resultado de uma estratégia, tanto dos pequenos quanto dos grandes proprietários, que visava à reposição da mão-de-obra. A mesma estratégia, segundo o autor, não teria sido abandonada pelos senhores após 1872, já na vigência da Lei do Ventre Livre.

Sobre os impactos da Lei, Sampaio (1994) acreditou que os proprietários foram se desinteressando pela reprodução natural. Constatação levantada por Teixeira (2001) em seu estudo sobre Mariana, em Minas Gerais, na segunda metade do século XIX. No referido estudo a autora encontrou, entre os crioulos, um elevado percentual de crianças e alta razão crianças/mulheres. Entretanto, após 1871, o percentual de crianças aumentou apenas nas propriedades com 20 ou mais cativos. A historiadora concluiu, assim como Sampaio (1994) que, em geral, a procriação sob a forma de garantir a reposição dos escravos não era mais estimulada pelos senhores.

$\mathrm{O}$ assunto em foco vem assumindo destaque entre os estudos sobre escravidão e os pesquisadores procuram analisá-lo inserido no tema das famílias escravas. Entretanto, algumas pesquisas estão preocupadas com a importância e o papel assumido pela reprodução para o sistema escravista, para os proprietários. E para os escravos? Qual o papel da reprodução para eles?

A procriação foi um meio pelo qual foram constituídas muitas das famílias escravas de Angra. Como no município as mães solteiras foram comuns, os filhos significaram a formação de muitas famílias.

Logo, é importante a obtenção de informações sobre a maternidade e a procriação. Quando as crianças eram geradas? Havia alguma relação com os calendários agrícola e 
religioso? Crianças legítimas e naturais eram concebidas nos mesmos meses? Qual o intervalo entre o nascimento de irmãos, levando-se em conta a legitimidade das crianças e a origem das mães? São algumas das perguntas que procuramos responder a seguir.

\section{TABELA 42}

Concepção das crianças escravas e ingênuas ilegítimas por subperíodos. Angra dos Reis, 1830-1886

\begin{tabular}{c|l|l|l|l|l|l|l|c}
\hline Mês & $\begin{array}{c}1805-1815 \\
\mathrm{n}^{\circ}(\%)\end{array}$ & $\begin{array}{c}1816-1826 \\
\mathrm{n}^{\circ}(\%)\end{array}$ & $\begin{array}{c}1827-1837 \\
\mathrm{n}^{\circ}(\%)\end{array}$ & $\begin{array}{c}1838-1848 \\
\mathrm{n}^{\circ}(\%)\end{array}$ & $\begin{array}{c}1849-1859 \\
\mathrm{n}^{\circ}(\%)\end{array}$ & $\begin{array}{c}1860-1871 \\
\mathrm{n}^{\circ}(\%)\end{array}$ & $\begin{array}{c}1872-1888 \\
\mathrm{n}^{\circ}(\%)\end{array}$ & $\begin{array}{c}1805-1888 \\
\mathrm{n}^{\circ}(\%)\end{array}$ \\
\hline Janeiro & $5(3,4)$ & $23(7,5)$ & $30(9,8)$ & $17(8,2)$ & $59(6,9)$ & $24(7,9)$ & $30(9,1)$ & $188(7,7)$ \\
Fevereiro & $11(7,5)$ & $22(7,1)$ & $25(8,1)$ & $12(5,8)$ & $53(6,3)$ & $23(7,6)$ & $22(6,7)$ & $168(6,8)$ \\
Março & $9(6,1)$ & $23(7,5)$ & $30(9,8)$ & $12(5,8)$ & $69(8,3)$ & $19(6,2)$ & $25(7,7)$ & $187(7,6)$ \\
Abril & $11(7,5)$ & $30(9,8)$ & $23(7,4)$ & $27(13,0)$ & $84(9,9)$ & $31(10,2)$ & $25(7,7)$ & $231(9,5)$ \\
Maio & $7(4,7)$ & $37(11,9)$ & $21(6,8)$ & $18(8,7)$ & $76(9,0)$ & $23(7,6)$ & $24(7,3)$ & $206(8,4)$ \\
Junho & $15(10,2)$ & $24(7,4)$ & $41(13,2)$ & $11(5,3)$ & $84(9,9)$ & $20(6,6)$ & $41(12,5)$ & $236(9,6)$ \\
$1^{\mathbf{0}}$ & $58(39,5)$ & $159(51,3)$ & $170(54,8)$ & $97(46,6)$ & $425(50,3)$ & $140(46,0)$ & $167(50,9)$ & $1.216(49,6)$ \\
semestre & & & & & & & \\
\hline Julho & $11(7,5)$ & $29(9,3)$ & $22(7,1)$ & $16(7,6)$ & $75(8,8)$ & $24(7,9)$ & $31(9,4)$ & $208(8,5)$ \\
Agosto & $16(10,9)$ & $17(5,5)$ & $31(10,0)$ & $16(7,6)$ & $82(9,7)$ & $30(9,8)$ & $24(7,3)$ & $216(8,8)$ \\
Setembro & $21(14,3)$ & $23(7,4)$ & $27(8,7)$ & $26(12,5)$ & $69(8,2)$ & $30(9,8)$ & $34(10,4)$ & $230(9,4)$ \\
Outubro & $17(11,6)$ & $25(8,1)$ & $18(5,8)$ & $20(9,6)$ & $58(6,8)$ & $26(8,6)$ & $28(8,5)$ & $192(7,8)$ \\
Novembro & $12(8,2)$ & $37(11,9)$ & $18(5,8)$ & $21(10,1)$ & $75(8,8)$ & $26(8,6)$ & $26(7,9)$ & $215(8,7)$ \\
Dezembro & $12(8,2)$ & $20(6,5)$ & $24(7,4)$ & $12(5,8)$ & $61(7,3)$ & $28(9,2)$ & $18(5,5)$ & $175(7,1)$ \\
$2^{\mathbf{0}}$ & $89(60,5)$ & $151(48,7)$ & $140(45,2)$ & $111(53,4)$ & $420(49,7)$ & $164(54,0)$ & $161(49,1)$ & $1.236(50,4)$ \\
semestre & & & & & & & \\
\hline Total & $147(100,0)$ & $310(100,0)$ & $310(100,0)$ & $208(100,0)$ & $845(100,0)$ & $304(100,0)$ & $328(100,0)$ & $2452(100,0)$ \\
\hline
\end{tabular}

FONTES: Livros de batismos de escravos da Ilha Grande de 1805-1847 e de 1850-1861; Livro de batismos de ingênuos da Ilha Grande de 1872-1888; Livro de batismos de escravos de Mambucaba, 1830-1871; Livro de batismos de escravos da Ribeira, 1824-1826; e Livro de batismos, casamentos e óbitos de escravos e de livres de Jacuecanga, 1800-1888. Convento do Carmo e Igreja de Jacuecanga, Angra dos Reis, RJ.

NOTAS: De um total de 2.815 crianças ilegítimas, não foram contadas 338, pois não havia informações sobre as datas de seus nascimentos e 25 crianças ficaram de fora da tabela pois eram gêmeas, sendo contadas apenas um de seus irmãos.

As mães solteiras, entre 1805-1888, tiveram seus filhos, preferencialmente, no segundo semestre. No entanto, muitas engravidaram nos seis primeiros meses (49,6\%). A proximidade entre os dois percentuais se refletiu na grande oscilação verificada nos subperíodos. O segundo semestre foi comum nos anos de 1805-1815, de 1838-1848 e de 1860-1871. Nos demais, o primeiro semestre se destacou.

Os meses de junho (9,6\%), abril (9,5\%), setembro (9,4\%) e agosto (8,8\%) foram, no total, os mais freqüentes. Relembrando o calendário agrícola apresentado por Marcílio (1986), não observamos correlação pois os meses citados acima tanto corresponderam aos de menor ritmo de trabalho (abril e setembro) quanto maior carga de afazeres (junho e agosto). 
Os meses de março $(7,6 \%)$ e de dezembro $(7,1 \%)$ foram meses com os menores percentuais. Coincidentemente foram períodos dedicados, respectivamente, a Quaresma e ao Advento. Ou seja, o calendário religioso, de certa forma, influenciava o comportamento dos cativos em suas vidas pessoais.

TABELA 43

Concepção das crianças escravas e ingênuas legítimas por subperíodos. Angra dos Reis, 1830-1886

\begin{tabular}{|c|c|c|c|c|c|c|c|c|}
\hline Mês & $\begin{array}{c}1805-1815 \\
n^{\circ}(\%)\end{array}$ & $\begin{array}{c}1816-1826 \\
n^{\circ}(\%)\end{array}$ & $\begin{array}{c}1827-1837 \\
\mathrm{n}^{\circ}(\%)\end{array}$ & $\begin{array}{c}1838-1848 \\
n^{\circ}(\%)\end{array}$ & $\begin{array}{c}1849-1859 \\
n^{\circ}(\%)\end{array}$ & $\begin{array}{c}1860-1871 \\
\mathrm{n}^{\circ}(\%)\end{array}$ & $\begin{array}{c}1872-1888 \\
n^{\circ}(\%)\end{array}$ & $\begin{array}{c}1805-1888 \\
\mathrm{n}^{\circ}(\%)\end{array}$ \\
\hline Janeiro & $5(5,6)$ & $12(8,2)$ & $11(7,4)$ & $2(3,3)$ & $11(7,1)$ & $2(8,7)$ & $2(4,1)$ & $45(6,7)$ \\
\hline Fevereiro & $7(7,8)$ & $8(5,4)$ & $8(5,4)$ & $2(3,3)$ & $12(7,7)$ & 0 & $2(4,1)$ & $39(5,8)$ \\
\hline Março & $10(11,2)$ & $6(4,1)$ & $9(6,0)$ & $5(8,3)$ & $9(5,8)$ & $2(8,7)$ & $5(10,2)$ & $46(6,8)$ \\
\hline Abril & $7(7,8)$ & $8(5,4)$ & $10(6,7)$ & $3(5,0)$ & $10(6,4)$ & $2(8,7)$ & $7(14,3)$ & $47(7,0)$ \\
\hline Maio & $3(3,4)$ & $20(13,6)$ & $14(9,4)$ & $6(10,0)$ & $9(5,8)$ & $3(13,1)$ & $5(10,2)$ & $60(8,9)$ \\
\hline Junho & $2(2,4)$ & $11(7,5)$ & $13(8,7)$ & $7(11,7)$ & $18(11,6)$ & $1(4,3)$ & $6(12,2)$ & $58(8,6)$ \\
\hline $\begin{array}{c}1^{0} \\
\text { semestre } \\
\end{array}$ & $34(38,2)$ & $65(44,2)$ & $65(43,6)$ & $25(41,6)$ & $69(4$ & 10( & $27(5$ & $295(43,9)$ \\
\hline Julho & $5(5,6)$ & $11(7,5)$ & $19(12,7)$ & $7(11,7)$ & $19(12,2)$ & $6(26,1)$ & $4(8,2)$ & $71(10,6)$ \\
\hline Agosto & $9(10,1)$ & $12(8,2)$ & $16(10,7)$ & $4(6,6)$ & $17(11,0)$ & $1(4,3)$ & $2(4,1)$ & $61(9,1)$ \\
\hline Setembro & $10(11,2)$ & $20(13,6)$ & $14(9,4)$ & $7(11,7)$ & $15(9,7)$ & $3(13,1)$ & $27(14,3)$ & $76(11,3)$ \\
\hline Outubro & $6(6,7)$ & $14(9,5)$ & $14(9,4)$ & $4(6,6)$ & $13(8,4)$ & $1(4,3)$ & $2(4,1)$ & $54(8,0)$ \\
\hline Novembro & $16(18,0)$ & $13(8,8)$ & $11(7,4)$ & $6(10,0)$ & $13(8,4)$ & $1(4,3)$ & $5(10,2)$ & $65(9,7)$ \\
\hline Dezembro & $9(10,1)$ & $12(8,2)$ & $10(6,7)$ & $7(11,7)$ & $9(5,8)$ & $1(4,3)$ & $2(4,1)$ & $50(7,4)$ \\
\hline $\begin{array}{c}2^{\mathbf{o}} \\
\text { semestre }\end{array}$ & $55(61,8)$ & $82(55,8)$ & $84(56,4)$ & $35(58,3)$ & $86(55,5)$ & $13(56,5)$ & $22(44,9)$ & $377(56,1)$ \\
\hline Total & $89(100,0)$ & $147(100,0)$ & $149(100,0)$ & $60(100,0)$ & $155(100,0)$ & $23(100,0)$ & $49(100,0)$ & $672(100,0)$ \\
\hline
\end{tabular}

FONTES: Livro de casamentos de escravos de Mambucaba, 1830-1875; Livro de casamentos de escravos da Ribeira, 1851-1886; e Livro de casamentos de escravos da Ilha Grande, 1851-1875. Convento do Carmo e Igreja de Jacuecanga, Angra dos Reis, RJ.

NOTA: De 794, não foram contadas 115 crianças em função da ausência de dados sobre suas datas de nascimento. Sete crianças gêmeas ficaram de fora da tabela, sendo contabilizadas apenas um de seus irmãos.

As informações acerca da concepção permite verificar quando os escravos estavam mais disponíveis. Entre as mulheres solteiras, o maior ou menor ritmo de trabalho agrícola, atividade exercida pela maior parte dos cativos, não influenciou suas vidas pessoais, ao contrário do que observamos sobre o calendário religioso. E as mulheres casadas?

Ao longo dos subperíodos, a maior parte das concepções ocorreram no segundo semestre (56,1\%). O mês de setembro, considerado de pouco trabalho no campo, foi o mais freqüente. Entretanto, a ligação com o calendário agrícola foi relativa, pois muitas foram as mulheres que engravidaram nos meses de julho e de agosto. Já o calendário religioso influenciou a vida das casadas. 
Comparando a concepção de solteiras e de casadas, verificamos algumas semelhanças: ambas engravidaram mais no segundo semestre; houve pouca ou nenhuma relação com o calendário agrícola; e maior influência das datas religiosas, como o Advento e a Quaresma; e, por último, o mês de fevereiro foi o menos comum. Portanto, não existiu diferenças consideráveis nas concepções entre mulheres solteiras ou casadas.

E os intervalos entre os nascimentos dos filhos? Casadas e solteiras pariam em intervalos próximos?

Entre 1805 e 1888, as mães solteiras africanas e crioulas tiveram seus filhos predominantemente, em intervalos de 23 a 28 meses, representando 45 (17,2\%) e 65 $(17,1 \%)$, respectivamente. No entanto, houve variações nos anos analisados. Entre os anos de 1805 a $1849^{137}$, as africanas tiveram seus filhos, preferencialmente, em intervalos de 17-22 meses e de 23-28 meses, respectivamente, 21 vezes $(16,9 \%)$ e $21(16,9 \%)$. Portanto, em intervalos de tempo menores que as crioulas, pois estas pariram entre 29-34 meses, somando $11(14,3 \%)$ e entre $23-28$ meses, somando $10(13,0 \%)^{138}$.

Entre 1850-1871, as crioulas pariram em intervalos menores que as africanas, visto que seus filhos nasceram, geralmente, entre $23-28$ meses, somando $36(17,6 \%)$ e entre 11-16 meses, representando 35 (17,2\%). Já em 24 casos $(17,6 \%)$ as africanas pariram entre 23-28 meses, e 20 (14,6\%) crianças nasceram 35-40 meses após seus irmãos. Depois de 1872, as escravas nascidas no Brasil tiveram seus filhos, preferencialmente, em intervalos de 23-28 meses, somando 19 (19,2\%) e de 17-22 meses, representando 17 (17,2\%).

A questão torna-se mais clara quando trabalhamos com os intervalos médios: no caso das solteiras, o intervalo médio de nascimento dos filhos das africanas, entre os anos de 1805 a 1849, foi de 45 meses, ou seja, três anos e nove meses, abaixo, portanto, do intervalo médio encontrado para as crioulas, de 50 meses, ou quatro anos e dois meses.

\footnotetext{
${ }^{137}$ A fim de analisar a questão optamos por comparar os dados para o primeiro e segundo semestres.

${ }^{138}$ Para a organização dos dados foram contados os intervalos entre os nascimentos de irmãos. Os nascidos entre os dois primeiros subperíodos foram contabilizados nos anos de 1850-1871, bem como as crianças nascidas na passagem de 1850-1871 para 1872-1888, contadas para os anos após 1872. Devemos lembrar que trabalhamos com os dados relativos às crianças que conseguiram sobreviver diante da elevada taxa de mortalidade infantil e que tiveram seus registros de batismos localizados. Isto é, os intervalos encontrados correspondem a intervalos máximos.
} 
Nos anos entre 1850 e 1871, num contexto de acirramento do processo de "crioulização" e de término da entrada de escravos oriundos do outro lado do Atlântico, os intervalos médios de nascimento dos filhos das africanas e das crioulas diminuíram. No caso das primeiras, o intervalo chegou a 36 meses, ou três anos, e entre as crioulas, 37 meses, ou três anos e um mês.

Comparando-se os dois primeiros subperíodos, constatamos que os intervalos médios de nascimento dos filhos das africanas e das crioulas diminuíram, chegando, inclusive a se igualarem.

A semelhança entre os intervalos médios de africanas e de crioulas, no segundo subperíodo, resultou da superação, neste momento, de possíveis diferenças culturais existentes entre africanas e crioulas, homogeneizando, por exemplo, as práticas acerca da procriação.

Já a diminuição dos intervalos médios ligou-se ao aumento da resistência senhorial quanto ao casamento de seus cativos. Aos escravos existentes em Angra nesse momento, a experiência familiar passou principalmente por famílias não legalizadas. Estas tinham sua representação máxima no nascimento de seus filhos, daí a diminuição dos intervalos médios.

Após 1872 o intervalo entre as crioulas foi de 39 meses, ou três anos e três meses, representando uma pequena variação com o que se viu no intervalo de tempo anterior ${ }^{139}$.

Entre as casadas, nos anos entre 1805 e 1849, os intervalos médios de nascimento dos filhos de africanas e crioulas foram, respectivamente, de 38 meses, ou três anos e dois meses, e de 43 meses, ou três anos e sete meses. Ou seja, o intervalo médio entre o nascimento do filho de uma mãe africana casada foi menor que o calculado para uma mãe crioula. A mesma tendência foi observada entre as solteiras. Portanto, nesses anos existiram fatores de ordem cultural definindo comportamentos diferentes entre africanas e crioulas. Sobre mulheres de igual origem, a variável estado conjugal também foi importante - pois as africanas casadas pariram, em média, a intervalo menor que as solteiras africanas e as crioulas casadas tiveram seus filhos, em média, em espaço de tempo menor que as solteiras também nascidas no Brasil. Isto ocorreu porque as relações

\footnotetext{
${ }^{139}$ O cálculo do intervalo médio de nascimento de filhos de africanas não foi feito para os anos de 1872 a
} 1888 em função do reduzido número de casos. 
legitimadas pelo casamento eram, em geral, mais estáveis. Uniões legitimadas entre escravos de mesmo senhor facilitaram o encontro e a convivência entre o casal.

Entre 1850 e 1871, a média encontrada para as africanas casadas foi, praticamente, semelhante àquela do período anterior, 36 meses, ou três anos. Este intervalo foi igual ao calculado para as africanas solteiras. Já o intervalo médio das crioulas casadas foi de 26 meses, ou dois anos e dois meses, representando o menor intervalo calculado entre as crioulas. Portanto, entre as escravas nascidas no Brasil, o fator condição conjugal continuava demarcando diferenças, beneficiando aquelas unidas legalmente.

Nos anos de 1872 a 1888, o intervalo médio de nascimento dos filhos das crioulas casadas elevou-se, chegando a 33 meses, ou dois anos e nove meses. Tal média era, ainda, menor que a encontrada para as solteiras.

O intervalo encontrado aqui se difere, por exemplo, do que foi visto para o agro fluminense. Florentino \& Góes (1997) concluíram que as cativas concebiam a intervalos de cerca de três anos, e seis meses a mais se fossem africanas.

No caso de Angra, em geral, as médias encontradas para as africanas casadas e solteiras foram menores que as calculadas para as crioulas. Entre 1805-1849, as crioulas de ambos estados conjugais tinham seus filhos em intervalos de cinco meses a mais que as africanas. Entre 1850-1871, as crioulas solteiras concebiam em intervalo de um mês a mais que as africanas também solteiras. A exceção ocorreu entre as africanas casadas que tinham seus filhos em intervalo de oito meses a mais que as crioulas de igual estado conjugal.

Portanto, muitas das mães que foram citadas em registros paroquiais eram solteiras. Algumas, após terem filhos naturais acabaram casando.

A origem das mães solteiras acompanhou as características demográficas verificadas nos capítulos anteriores. Nos anos da primeira metade do século, mulheres africanas foram mais freqüentes como mães solteiras; no entanto, nos anos após 1850, as crioulas se destacaram. Isso se deu em meio ao aumento do percentual de crioulos, entre os escravos de Angra dos Reis. 
As mulheres concebiam tanto no primeiro quanto no segundo semestres. Houve pouca influência do calendário agrícola, enquanto o religiosos interferiu no comportamento dos escravos.

A prática relativa à procriação variou de acordo com o recorte temporal, com a origem e com o estado conjugal das mulheres.

As famílias formadas legalmente tiveram, em geral, seus filhos em intervalos médios menores que as solteiras. Isto porque elas participaram de relacionamentos com cativos de seus senhores, facilitando o contato e convívio.

Dentre as casadas, o fator origem definiu comportamentos diferentes. Nos anos anteriores a 1850, as africanas pariram em intervalo médio menor que as crioulas. Entre 1850 e 1871, o intervalo calculado para as crioulas foi menor que o encontrado para as africanas. A média localizada para as últimas se igualou ao das africanas solteiras e, praticamente, ao das crioulas também solteiras.

Todas as mulheres vistas no presente capítulo tiveram seus filhos convertidos ao catolicismo. Na próxima parte tratamos dos significados do ritual do batismo. 


\section{PARTE III \\ COMPADRIO ENTRE ESCRAVOS}

\section{INTRODUÇÃO}

Constatamos na Parte II que as famílias legitimadas pelo casamento tornaram-se menos freqüentes. Em oposição, mulheres solteiras e seus filhos foram cada vez mais comuns na localidade. No entanto, independentemente da legitimidade das famílias, todas (ou quase) conduziram seus filhos à pia batismal.

A partir de agora, as cerimônias de batismo serão o alvo de pesquisa. Nelas, pais, batizandos, padrinhos e madrinhas oficializaram vínculos de amizade e de solidariedade necessários para a dura vida em cativeiro.

Para o estudo, dividimos os registros em função da idade dos batizandos. Embora o sacramento tenha representado, tanto para crianças quanto para adultos, a conversão ao cristianismo, os responsáveis pela escolha de padrinhos e de madrinhas foram diferentes, assim como foram diversos os interesses por detrás das ditas escolhas.

No caso dos batismos de adultos, as escolhas de padrinhos e madrinhas foram feitas por seus proprietários, pois seria pouco provável que cativos recém-chegados fossem capazes de selecionar seus próprios protetores. Dependendo da forma como os senhores encaravam o ritual, selecionavam indivíduos que cumpririam formalmente o papel de padrinhos ou de madrinhas, ou convidavam indivíduos que ajudariam o recémchegado em seu processo de adaptação.

Nos batismos de crianças, seus pais escolhiam os padrinhos e as madrinhas. Eles buscavam com o ritual não apenas a conversão de seus filhos, mas pais espirituais para seus rebentos e a oficialização de laços de amizade, mediante o compadrio. Evidentemente, também nos batismos de crianças houve relativa atuação senhorial, pois os pais eram, apesar de tudo, escravos.

Ao longo da segunda metade do século XIX, num contexto econômico desfavorável e de risco de separação das famílias pela venda, o batismo oferecia pais 
espirituais que poderiam substituir os pais carnais, ou mesmo auxiliá-los na criação de seus filhos.

Portanto, na Parte III nos dedicamos aos laços oriundos do batismo. Buscando comprovar as três idéias lançadas, optamos por dividir a análise dos batismos por faixas etárias. No capítulo 7, apresentamos o significado do sacramento para a Igreja e algumas notas sobre os registros estudados. No capítulo 8 abordamos os sacramentos que contaram com batizandos adultos, observando algumas características demográficas dos mesmos e os perfis dos padrinhos e das madrinhas. Enquanto as crianças escravas e ingênuas foram tratadas no capítulo 9, bem como as condições sociais de seus protetores espirituais, entre outros. Visando aprofundar nosso conhecimento sobre os laços de apadrinhamento e de compadrio, elaboramos o capítulo 10. Neste, observamos a freqüência de afilhados por padrinhos e madrinhas, quais as propriedades que mais ofereciam padrinhos e madrinhas escravos e os possíveis motivos para tal.

As fontes trabalhadas foram os livros de batismo de escravos. Os dados relativos aos adultos foram divididos nos seguintes subperíodos: 1805-1815, 1816-1826, 18271837, 1838-1848, 1849-1859 e 1860-1871. No caso das crianças, além de diferenciar as escravas das ingênuas e utilizar esses subperíodos, incluímos os dados de 1872-1888. A fim de verificar as variáveis ao longo do tempo, comparamos as informações para todos os intervalos de anos, dando particular atenção àquela entre a primeira e a segunda metade do século XIX. 


\section{CAPÍTULO 7-NOTAS SOBRE O BATISMO}

Ritual responsável pela purificação do pecado original, o sacramento do batismo oferecia ao pagão a passagem ao cristianismo, sendo-lhe conferido um nome cristão ou de um santo, tornando-o apto a participar das cerimônias da Igreja, além de adquirir igualdade, humanidade e liberdade (GUDEMAN \& SCHWARTZ, 1988).

Constituíram-se determinadas regras na hora da escolha dos "pais espirituais", forma como eram compreendidos os padrinhos e madrinhas: não poderiam ser os pais carnais, deveriam ser batizados e conhecedores da doutrina católica (GUDEMAN \& SCHWARTZ, 1988, p. 39).

A eles caberia a formação moral dos afilhados, entendidos como "substitutos eventuais do pai e da mãe, são parcialmente responsáveis pela educação espiritual daquele ou daquela que levaram à pia batismal” (LEBRUN, 1998, p. 89).

Entretanto, no âmbito da sociedade escravista, além das limitações impostas pela Igreja, Gudeman \& Schwartz (1988) constataram as restrições colocadas pelo social: a incompatibilidade de proprietários como padrinhos de seus próprios cativos. Isto ocorria porque a relação de apadrinhamento correspondia à formação de um vínculo espiritual de proteção e de igualdade entre cristãos, incompatível com a relação social de dominação.

"O batismo, por representar igualdade, humanidade e liberação do pecado, simbolizava qualidades incompatíveis com a condição de escravo e apresentava uma contradição potencial que era resolvida não com a abolição da escravidão ou do batismo, mas com a manutenção em separado desses elementos conflitantes” (SCHWARTZ, 1995, p. 331).

Entre os registros de batismo do município em estudo, de um total de 4.207 sacramentos envolvendo adultos, crianças escravas e ingênuas como batizandos, encontramos oito registros onde os proprietários apareceram como padrinhos de seus próprios escravos. Seus afilhados foram crianças, compreendendo, portanto, ínfimos $0,2 \%$ dos sacramentos.

O mesmo padrão foi encontrado em várias localidades, como Campos, nos séculos XVII e XVIII (FARIA, 1998, p. 310); no Recôncavo Baiano, no período colonial 
(SCHWARTZ, 1995, p. 331); e na freguesia de São José, no Rio de Janeiro, na primeira metade do século XIX (FERREIRA, 2000, p. 187).

Além da conversão do pagão ao cristianismo, as cerimônias e os registros de batismo desempenharam algumas funções práticas, como registrar, por escrito, doações, concessões de alforrias e até a comunicação de compra dos batizandos.

Casos de doações, com assinatura inclusive de testemunhas, foram vistos em vinte e um registros, correspondendo a $0,7 \%$ do total de registros de crianças, que foram predominantemente doadas pelos proprietários a seus filhos, correspondendo a 11 casos, seguido por sete doações aos netos, duas aos sobrinhos e uma para a irmã. O batizado de Caetana, em 1861, na Igreja Matriz da Ilha Grande, ilustra o que foi dito. A inocente, nascida a 15 de janeiro daquele ano, era filha de Generosa africana, ambas cativas de Felisbino Martins. Este, no ato do batismo, doou a inocente ao seu filho Benedito Martins da Silva ${ }^{140}$.

Dentre estes casos, foram vistos promessas de alforrias após o falecimento do novo dono. Situação encarada por Benedito, batizado em 1853 e nascido em 12 de junho do dito ano, filho de Teresa crioula. No momento do registro da cerimônia, o proprietário João da Silva Braga, doou o batizando ao seu filho José Antônio da Silva, devendo o inocente ser alforriado quando da morte do novo proprietário.

Outros quatro registros apresentaram a promessa da alforria. Destes, em apenas um o inocente foi liberto no ato da cerimônia. Foi o caso de Manoel, batizado em 1817 na Ilha Grande, nascido em 29 de julho do mesmo ano, filho de Maria africana de Angola. Seu proprietário, Manoel de Siqueira Coutinho, alforriou o inocente ${ }^{141}$. Temos outro caso, onde o inocente seria alforriado após a morte do senhor. A menor Camila, na época do batismo com oito meses, filha de Eugênia crioula, em Mambucaba, no ano de 1856, seria liberta após a morte do proprietário, Antônio Joaquim Martins Guimarães ${ }^{142}$.

A comunicação de compra do batizando Marcos, sete anos, estava na anotação do batismo de 1871, em Mambucaba. Ele, filho de Benedita crioula, cativa de Rita Maria do Espírito Santo, havia sido comprado por Delfim Caetano de Lima ${ }^{143}$.

\footnotetext{
${ }^{140}$ Livro de batismos de escravos da Ilha Grande, 1850-1871. Igreja de Jacuecanga, Angra dos Reis, RJ.

${ }^{141}$ Livro de batismos de escravos da Ilha Grande, 1805-1830. Igreja de Jacuecanga, Angra dos Reis, RJ.

${ }^{142}$ Livro de batismos de escravos de Mambucaba, 1830-1859. Convento do Carmo, Angra dos Reis, RJ.

${ }^{143}$ Livro de batismos de escravos de Mambucaba, 1860-1871. Convento do Carmo, Angra dos Reis, RJ.
} 
De um total de 4.207 batismos para os anos de 1805 a 1888, houve uma média de 50,7 cerimônias ao ano.

Dos 1.093 proprietários de batizandos, a grande maioria compreendeu escravistas mencionados em apenas um registro, somando 512 senhores, ou $46,8 \%{ }^{144}$. Este foi o caso de Manoel Joaquim dos Santos, citado em registro anotado no livro da Ilha Grande, onde a escrava Eva, de origem desconhecida, teve seu filho Calixto, de um ano, batizado em $1851^{145}$. No extremo oposto estavam José Joaquim Guimarães e José Jordão da Silva Vargas, proprietários, respectivamente, de 121 e 85 batizandos, tanto na Ilha Grande quanto em Mambucaba.

Entre os proprietários havia 18 forros, sendo 12 homens e seis mulheres. Dentre eles, destacamos a proprietária Tomasia Maria de Jesus, preta forra. No ano de 1824, na Ilha Grande, foi batizado um escravo adulto de nome Feliciano, africano Cabinda, de sua propriedade. Como padrinho de Feliciano, Vitoriano, preto e escravo. Vitoriano era esposo de Tomasia Maria de Jesus ${ }^{146}$. Ou seja, a proprietária, uma forra, adquiriu um trabalhador compulsório adulto e, no entanto, estava casada com um escravo... Se Tomasia e seu cônjuge foram capazes de obter um africano adulto, por que não buscaram adquirir a carta de alforria de Vitoriano? Será que o senhor não aprovava a venda? Ou será que era interessante ao casal que Vitoriano continuasse sendo escravo, permitindo a eles o acesso, por exemplo, às terras do seu proprietário? Ficam as perguntas.

A história descrita introduz um perfil de proprietários localizado nos registros. Trata-se de cinco senhores, sendo que eles também eram escravos ${ }^{147}$ : Antônio, escravo de Antônio de Matos da Nóbrega, possuía uma escrava de nome Desidéria crioula, presente num registro de batismo de 1828, na Ilha Grande, como madrinha ${ }^{148}$; Baltazar, escravo de Antônio de Matos da Nóbrega, era proprietário do batizando Antônio africano Angola, na

\footnotetext{
${ }^{144}$ A representatividade de batismos simples pode ser um indício de que os escravos pertenciam a pequenas propriedades.

${ }^{145}$ Livro de batismos de escravos da Ilha Grande, 1850-1871. Igreja de Jacuecanga, Angra dos Reis, RJ. ${ }^{146}$ Livro de batismos de escravos da Ilha Grande, 1805-1830. Igreja de Jacuecanga, Angra dos Reis, RJ.

147 Sobre alguns dos motivos que levaram escravos a adquirir cativos, destacamos o estudo sobre as manumissões no Rio de Janeiro, realizado por Sampaio (2005). O autor observou que: "diversos alforriados entregavam outros escravos como pagamento por sua liberdade”. Assim, "o senhor não era obrigado sequer a dirigir-se ao mercado para adquirir um novo cativo que repusesse aquele que estava sendo liberto: esse trabalho ficava por conta dos que desejassem adquirir a sua liberdade" (SAMPAIO, 2005, p. 315). Mesmo processo foi visto por Florentino (2005, p. 352).

${ }^{148}$ Livro de batismos de escravos da Ilha Grande, 1805-1830. Igreja de Jacuecanga, Angra dos Reis, RJ.
} 
Ilha Grande, em $1825^{149}$; Claudina, parda, escrava de Dona Luiza Joaquina de Oliveira, na Ilha Grande, era senhora de Antônia africana Guiné, mãe de dois batizandos na década de $1820^{150}$; Rufina crioula, escrava de Joaquim Ribeiro da Cunha, era proprietária de Maria africana do Congo, mãe de uma batizanda, em $1825^{151}$; e Sebastião, pardo, cativo de Pedro José Travassos, era senhor de Rosa africana Angola, batizada em 1815, na Ilha Grande, e mãe de três batizandos nos anos de 1815, 1817 e $1820^{152}$.

Dos batizandos, observamos, no total, o predomínio de crianças, escravas e ingênuas, correspondendo a 3.632 (87,1\%), enquanto os adultos estiveram presentes em $537(12,9 \%)$ sacramentos.

\section{TABELA 44}

Faixas etárias dos batizandos por subperíodos. Angra dos Reis, entre os anos de 1805 e 1888

\begin{tabular}{|c|c|c|c|c|c|c|c|c|}
\hline \multirow[t]{2}{*}{ Subperíodos } & \multicolumn{2}{|c|}{ Crianças } & \multicolumn{2}{|c|}{ Adultos } & \multicolumn{2}{|c|}{ Ingênuos } & \multicolumn{2}{|c|}{ Total } \\
\hline & $\mathrm{n}^{0}$ & $\%$ & $\mathrm{n}^{\mathrm{o}}$ & $\%$ & $\mathrm{n}^{\mathrm{o}}$ & $\%$ & $\mathrm{n}^{\mathrm{o}}$ & $\%$ \\
\hline $1805-1815$ & 267 & 89,0 & 33 & 11,0 & 0 & & 300 & $\overline{100,0}$ \\
\hline $1816-1826$ & 519 & 70,9 & 213 & 29,1 & $\underline{0}$ & & 732 & 100,0 \\
\hline 1827-1837 & 543 & 79,0 & 144 & 21,0 & $\overline{0}$ & & 687 & 100,0 \\
\hline $1838-1848$ & 342 & 87,5 & 49 & 12,5 & 0 & & 391 & 100,0 \\
\hline 1849-1859 & 1.124 & 92,1 & 96 & 7,9 & 0 & & 1.220 & 100,0 \\
\hline $1860-1871$ & 437 & 99,5 & 2 & 0,5 & 0 & & 439 & 100,0 \\
\hline $1872-1888$ & 0 & & 0 & & 400 & 100,0 & 400 & 100,0 \\
\hline $1805-1888$ & 3.232 & 77,5 & 537 & 12,9 & 400 & 9,6 & 4.169 & 100,0 \\
\hline
\end{tabular}

FONTES: Livros de batismos de escravos da Ilha Grande de 1805-1847 e de 1850-1861; Livro de batismos de ingênuos da Ilha Grande de 1872-1888; Livro de batismos de escravos de Mambucaba, 1830-1871; Livro de batismos de escravos da Ribeira, 1824-1826; e Livro de batismos, casamentos e óbitos de escravos e de livres de Jacuecanga, 1800-1888. Convento do Carmo e Igreja de Jacuecanga, Angra dos Reis, RJ.

NOTA: Em 38 batismos não havia informações acerca da idade dos batizandos.

O predomínio de crianças batizadas ocorreu em todos os subperíodos. Os adultos sempre foram minoria, estando em maior representatividade entre 1816-1826, correspondendo a 29,1\%. Após 1872, quando utilizamos um livro de ingênuos, o percentual de participação das crianças chegou a 100,0\%.

O percentual de crianças batizadas foi maior do que o encontrado para a freguesia de Inhaúma, no Rio de Janeiro, entre 1817 e 1842. Nesta, de 1.589 batismos, 1.118 (70,4\%) envolveram crianças e 471 (29,6\%), adultos (GÓES, 1993, p. 57). O mesmo se

\footnotetext{
${ }^{149}$ Livro de batismos de escravos da Ilha Grande, 1805-1830. Igreja de Jacuecanga, Angra dos Reis, RJ.

${ }^{150}$ Livro de batismos de escravos da Ilha Grande, 1805-1830. Igreja de Jacuecanga, Angra dos Reis, RJ.

${ }^{151}$ Livro de batismos de escravos da Ilha Grande, 1805-1830. Igreja de Jacuecanga, Angra dos Reis, RJ.

${ }^{152}$ Livro de batismos de escravos da Ilha Grande, 1805-1830. Igreja de Jacuecanga, Angra dos Reis, RJ.
} 
deu na freguesia urbana de São José, na cidade do Rio de Janeiro, onde, entre 1802 e 1821, $3.565(60,33 \%)$ e 2.344 (39,67\%) foram, respectivamente, crianças e adultos (FERREIRA, 2000, p. 183).

Enquanto as crianças foram tornando-se cada vez mais comuns, a participação de adultos como batizandos foi diminuindo. Este movimento esteve relacionado à abolição do tráfico de escravos africanos ${ }^{153}$, em 1850. Este acontecimento significou a redução da entrada de pagãos e, portanto, da participação dos adultos nas cerimônias.

Entre os batizando com mais de 14 anos, nos anos de 1805-1871, predominaram as cerimônias realizadas nas igrejas das freguesias, compreendendo 496 (92,4\%), enquanto batismos ocorridos em oratórios e capelas das fazendas somaram 41 (7,6\%). O perfil manteve-se inalterado na passagem dos anos, visto que na primeira metade do século, entre 1805 e 1849, os sacramentos ministrados nas igrejas chegaram a 427 $(91,4 \%)$ e as demais 40 (8,6\%) ocorreram fora, e entre 1850-1871, foram, respectivamente, $69(98,6 \%)$ e um $(1,4 \%)$.

O mesmo foi visto nas cerimônias que envolveram as crianças, tanto escravas quanto ingênuas. No intervalo em estudo, as igrejas constituíram o local privilegiado para a realização dos batismos, representando 3.562 (98,0\%) e os sacramentos ministrados em outros locais somaram 70. Entre 1805-1849, as freqüências encontradas foram, respectivamente, $1.696(97,6 \%)$ e 41 (2,4\%). Nos anos entre 1850 e 1871, 1.465 e 29 e, de 1872 a 1888, 400 (100,0\%) sacramentos foram ministrados na Igreja Matriz.

Os registros de batismos de adultos apresentaram, ligeiramente, dois ou mais escravos de um mesmo senhor sendo convertidos ao cristianismo no mesmo momento. Os batismos coletivos somaram 286 (53,3\%), contra 251 (46,7\%) batismo simples. Entre 1805 e 1849, os coletivos representaram 248 (53,1\%) e os simples, 219 (46,9\%). De 1850 a 1871 chegaram, respectivamente, a 38 (54,3\%) e 32 (45,7\%).

Comportamento diferente foi visto entre as crianças. No total, os batismos simples somaram 3.352 (92,2\%) e os coletivos, 280. Entre 1805-1849 foram 1.563 (90,0\%) e 174 (10,0\%). Entre 1850-1871, 1.388 (92,8\%) e 106, respectivamente. Nos anos de 1872 a 1888 foram 400 (100,0\%) batismos simples.

\footnotetext{
${ }^{153}$ Foi comum o batismo de escravos provenientes dos portos congo-angolanos, no momento do embarque. Escravos embarcados pela Costa da Mina, geralmente, não foram batizados na África.
} 
Entre as crianças foram predominantes os batismos simples, aumentando, percentualmente, ao longo do tempo.

Os registros que anotaram a conversão de mais de um pagão, ou seja, os batismos coletivos, levam-nos a crer na existência de algum grau de interferência senhorial, ao menos na escolha da data da cerimônia. Havia senhores que esperavam acumular determinado número de cativos, para marcar o sacramento, visando evitar a interrupção das atividades diárias. Desta forma, nas cerimônias que envolviam adultos, havia maior interferência senhorial, se comparado aos sacramentos das crianças ${ }^{154}$. Os senhores que dispunham de escravos para o batismo coletivo deveriam ser detentores de médios a grandes plantéis.

Portanto, os registros de batismo analisados em seguida, além de servir como prova da conversão de determinada pessoa ao cristianismo, exerceu o papel de documento no qual eram registrados doações, alforrias e compras.

Verificamos o perfil dos proprietários que conduziram os cativos ao batismo. Grande parte eram homens livres, mas havia alforriados e até mesmo escravos, na qualidade de escravistas. Estes indivíduos tiveram, geralmente, um escravo sendo levado à pia batismal.

Dentre os batizandos, a maior parte era formada por crianças, muitas convertidas ao catolicismo em seus primeiros meses de vida. Os batismos de adultos, menos freqüentes, foram determinados pela chegada de africanos a Angra dos Reis, estando, por sua vez, vinculada à existência do tráfico atlântico. Enfim, após 1850, adultos sendo convertidos ao catolicismo praticamente desapareceu.

As cerimônias, independentemente da faixa etária dos batizandos, ocorreram, principalmente, nas igrejas existentes nas freguesias. No entanto, entre os adultos, os batismos coletivos foram ligeiramente predominantes, demonstrando a intervenção senhorial no momento de seleção da data para a realização dos sacramentos. Não obstante, grande parte das crianças participaram de batismos simples.

Em arremate, feitas as anotações iniciais sobre os registros de batismos, passemos, no próximo capítulo, ao estudo dos batismos de adultos.

\footnotetext{
${ }^{154}$ Não queremos dizer que não houvesse intervenção dos senhores nos batismos de crianças. Elas eram escravas, não eram “donas” de suas próprias vidas.
} 


\section{CAPÍTULO 8-BATISMO DE ESCRAVOS ADULTOS}

Os senhores foram os responsáveis pela seleção de padrinhos e de madrinhas, quando do batismo de cativos adultos. Alguns proprietários consideraram aquela cerimônia, uma simples formalidade, mas outros, tinham determinados interesses; ou seja, a seleção de indivíduos que, na qualidade de pais espirituais, poderiam auxiliar a inserção do recém-chegado à realidade escravista.

TABELA 45

Sazonalidade das cerimônias de batismos de adultos por subperíodos. Angra dos Reis, 1805-1871

\begin{tabular}{ccc|c|c|c|c|c|c}
\hline Mês & $\begin{array}{c}1805-1815 \\
n^{\circ}(\%)\end{array}$ & $\begin{array}{c}1816-1826 \\
n^{\circ}(\%)\end{array}$ & $\begin{array}{c}1827-1837 \\
n^{\circ}(\%)\end{array}$ & $\begin{array}{c}1838-1848 \\
n^{\circ}(\%)\end{array}$ & $\begin{array}{c}1849-1859 \\
n^{\circ}(\%)\end{array}$ & $\begin{array}{c}1860-1871 \\
n^{\circ}(\%)\end{array}$ & $\begin{array}{c}1805-1871 \\
n^{\circ}(\%)\end{array}$ \\
\hline Janeiro & $2(6,1)$ & $1(0,4)$ & $1(0,8)$ & $19(43,2)$ & $13(14,2)$ & $01(50,0)$ & $36(6,9)$ \\
Fevereiro & $2(6,1)$ & $13(6,1)$ & $11(8,1)$ & 0 & $11(12,1)$ & 0 & $38(7,3)$ \\
Março & $1(3,0)$ & $4(1,8)$ & $16(11,9)$ & 0 & $14(15,4)$ & 0 & $35(6,8)$ \\
Abril & 0 & $17(7,9)$ & $12(8,9)$ & $3(6,8)$ & $1(1,1)$ & 0 & $33(6,4)$ \\
Maio & $2(6,1)$ & $28(13,6)$ & $15(11,1)$ & 0 & $2(2,2)$ & 0 & $47(9,1)$ \\
Junho & $19(57,6)$ & $96(45,1)$ & $26(19,2)$ & $6(13,6)$ & $16(17,6)$ & $1(50,0)$ & $164(31,7)$ \\
$1^{\mathbf{o}}$ semestre & $26(78,8)$ & $159(74,6)$ & $81(60,0)$ & $28(63,6)$ & $57(62,6)$ & $2(100,0)$ & $353(68,1)$ \\
\hline Julho & $1(3,0)$ & $29(13,6)$ & $34(25,1)$ & 0 & $16(17,6)$ & 0 & $80(15,4)$ \\
Agosto & $3(9,0)$ & $11(5,2)$ & 0 & $1(2,3)$ & 0 & 0 & $15(2,9)$ \\
Setembro & 0 & $5(2,3)$ & $1(0,8)$ & $1(2,3)$ & $3(3,3)$ & 0 & $10(1,9)$ \\
Outubro & $1(3,0)$ & $5(2,3)$ & $4(3,0)$ & $3(6,8)$ & $3(3,3)$ & 0 & $16(3,1)$ \\
Novembro & $2(6,1)$ & $3(1,3)$ & $2(1,5)$ & 0 & $9(9,9)$ & 0 & $16(3,1)$ \\
Dezembro & 0 & $1(0,4)$ & $13(9,6)$ & $11(25,0)$ & $3(3,3)$ & 0 & $28(5,4)$ \\
$2^{\mathbf{o}}$ semestre & $7(21,2)$ & $54(25,3)$ & $54(40,0)$ & $16(36,4)$ & $34(37,4)$ & 0 \\
\hline Total & $33(100,0)$ & $213(100,0)$ & $135(100,0)$ & $44(100,0)$ & $91(100,0)$ & $2(100,0)$ & $518(100,0)$ \\
\hline
\end{tabular}

FONTES: Livros de batismos de escravos da Ilha Grande de 1805-1847 e de 1850-1861; Livro de batismos de escravos de Mambucaba, 1830-1871; Livro de batismos de escravos da Ribeira, 1824-1826; e Livro de batismos, casamentos e óbitos de escravos e de livres de Jacuecanga, 1800-1888. Convento do Carmo e Igreja de Jacuecanga, Angra dos Reis, RJ.

NOTA: Ficaram de fora da contagem 19 cerimônias por ausência de informações.

A maior incidência de conversões de adultos ao catolicismo se deu entre os meses de janeiro a junho, correspondendo a 68,1\%. Excluindo os subperíodos de 1838-1848 e de 1860-1871, o mês de junho concentrou o maior número de batismos. Por que muitas cerimônias foram realizadas em junho? Por tratar-se de um período de intenso trabalho no campo, seguindo o calendário agrícola elaborado por Marcílio (1986), podemos afirmar que a necessidade de mão-de-obra levava os senhores a obterem escravos e, em seguida, conduzi-los ao sacramento. 
TABELA 46

Sexo dos adultos batizados por subperíodos. Angra dos Reis, entre os anos de 1805 e 1871

\begin{tabular}{l|lr|lr|rr}
\hline Subperíodos & \multicolumn{2}{|c|}{ Masculino } & \multicolumn{3}{c|}{ Feminino } & \multicolumn{3}{c}{ Total } \\
& $\mathrm{n}^{\text {o }}$ & $\%$ & $\mathrm{n}^{\text {o }}$ & $\%$ & $\mathrm{n}^{\text {o }}$ & \% \\
\hline $1805-1815$ & 21 & 63,6 & 12 & 36,4 & 33 & 100,0 \\
$1816-1826$ & 159 & 74,6 & 54 & 25,4 & 213 & 100,0 \\
$1827-1837$ & 91 & 63,2 & 53 & 36,8 & 144 & 100,0 \\
$1838-1848$ & 35 & 71,4 & 14 & 28,6 & 49 & 100,0 \\
$1849-1859$ & 79 & 82,3 & 17 & 17,7 & 96 & 100,0 \\
$1860-1871$ & 1 & 50,0 & 1 & 50,0 & 2 & 100,0 \\
$1805-1871$ & 386 & 71,9 & 151 & 28,1 & 537 & 100,0 \\
\hline
\end{tabular}

FONTES: Livros de batismos de escravos da Ilha Grande de 1805-1847 e de 1850-1861; Livro de batismos de escravos de Mambucaba, 1830-1871; Livro de batismos de escravos da Ribeira, 1824-1826; e Livro de batismos, casamentos e óbitos de escravos e de livres de Jacuecanga, 1800-1888. Convento do Carmo e Igreja de Jacuecanga, Angra dos Reis, RJ.

A maior parte dos adultos batizados em junho e nos demais meses era do sexo masculino. Tal característica esteve relacionada ao tráfico de escravos africanos, assinalado, entre outros, pela importação, em maior quantidade, dos cativos daquele sexo.

O predomínio de homens batizados foi visto também para Inhaúma, entre 1817 e 1842 , onde $68,7 \%$ dos escravos adultos eram do sexo masculino ${ }^{155}$.

A ligação entre tráfico Atlântico e batismos de adultos pode ser observada quando avaliamos as origens dos adultos convertidos: os africanos somaram 500 (93,1\%). Entre os homens, nos anos de 1805 a 1849, 303 (93,2\%) eram daquela origem, dois (0,6\%) eram crioulos e 20 (6,2\%) não tiveram sua origem definida. Entre 1850-1871, 57 (93,4\%) foram africanos e quatro (6,6\%), de origem indefinida. As mulheres somaram 137 (96,5\%) e cinco (3,5\%), respectivamente, africanas e cativas de origens indefinidas, entre 1805-1849. Nos anos de 1850 a 1871, foram, respectivamente, oito (88,9\%) e uma $(11,1 \%)$.

Estamos falando, portanto, de cativos de origem africana, sofrendo influência do tráfico de escravos, que era seletivo, privilegiando os homens, entendidos como mais aptos ao trabalho braçal.

Os dois crioulos batizados foram Manoel, convertido em janeiro de 1848 na Fazenda da Cruz, em Mambucaba, filho ilegítimo de Francisca crioula, ambos cativos de

${ }^{155}$ Góes (1993, p. 59). 
Dionísio Fernandes, e Francisco, batizado na Igreja Matriz de Mambucaba, em junho de $1849^{156}$. Ambos foram exceções, tanto por causa da origem dos mesmos entre os adultos quanto pela idade em que os crioulos eram batizados.

Por que os dois foram batizados tardiamente? Isto poderia ter decorrido ou do descaso dos senhores em incentivar a participação de seus escravos na cerimônia, ou por pouco interesse dos pais em converter seus filhos ao catolicismo. Embora não possamos apresentar uma argumentação segura, parece que o sacramento, como dizem diversos pesquisadores (SCHWARTZ, 1995; FLORENTINO \& GÓES, 1997; GÓES, 1993, FERREIRA, 2000), possuía uma importância para a população escrava, permitindo a adoção de laços de compadrio e de apadrinhamento e, portanto, de amizade, envolvendo cativos, livres e forros. Da mesma forma, para os proprietários, o registro de batismo de criança desempenhava, entre outros, a função de definir e deixar em prova a posse do menor. Portanto, os dois batizandos adultos crioulos devem ser entendidos como exceções, numa sociedade onde vínculos decorrentes dos batismos desempenhavam destacado papel.

Dos africanos presentes nas cerimônias como batizandos, analisamos as suas procedências. Sobre isso, valem algumas observações.

Em primeiro, o termo africano, representa, na verdade, uma construção da segunda metade do século XIX.

Já as procedências não definem, necessariamente, o local de origem dos africanos, sendo que "não existe qualquer homogeneidade nos nomes das procedências: vão desde os nomes de Ilhas, portos de embarque, vilas e reinos, a pequenos grupos étnicos” (SOARES, 2000, p. 109).

As procedências definidas nos registros de batismo foram organizadas em três grandes grupos, isto é, África Central Atlântica, África Ocidental e África Oriental ${ }^{157}$.

A África Central Atlântica foi a procedência predominante dos cativos homens, somando 104 (46,8\%). Em seguida, estavam os escravos da África Oriental, presentes em

\footnotetext{
${ }^{156}$ Livro de batismos de escravos de Mambucaba, 1830-1859. Convento do Carmo, Angra dos Reis, RJ.

157 As distribuições dos locais baseou-se em Florentino (1995, p. 87-88) e Karasch (2000a, p. 46). Consideramos como África Central Atlântica, Congo, Cassange, Rebola, Cabinda, Benguela, Ambaca, Angola, Camundongo, Monjolo, Ganguela; África Ocidental, cativos declarados como Mina, Calabar e Guiné; e África Oriental, os escravos considerados de Moçambique, Quilimane e Inhambane.
} 
76 (34,3\%) batismos e os da África Ocidental, em 42 (18,9\%). Entre os anos de 1805 a 1815, 71,4\% dos homens africanos provinham da África Ocidental. Posteriormente houve predomínio dos cativos vindos da África Central Atlântica.

TABELA 47

Procedências dos adultos africanos batizados do sexo masculino por subperíodos.

Angra dos Reis, 1805-1871

\begin{tabular}{|c|c|c|c|c|c|c|c|c|}
\hline \multirow[t]{2}{*}{ Subperíodos } & \multicolumn{2}{|c|}{ AOC } & \multicolumn{2}{|c|}{ ACA } & \multicolumn{2}{|c|}{ AOR } & \multicolumn{2}{|c|}{ Total } \\
\hline & $n^{0}$ & $\%$ & $n^{o}$ & $\%$ & $\mathrm{n}^{\mathrm{o}}$ & $\%$ & $\mathrm{~N}^{\mathrm{o}}$ & $\%$ \\
\hline $1805-1815$ & 15 & 71,4 & 6 & 28,6 & 0 & & 21 & 100,0 \\
\hline $1816-1826$ & 1 & 0,9 & 59 & 53,2 & 51 & 45,9 & 111 & 100,0 \\
\hline 1827-1837 & 20 & 31,2 & 25 & 39,1 & 19 & 29,7 & 64 & 100,0 \\
\hline $1838-1848$ & 0 & & 5 & 55,6 & 4 & 44,4 & 9 & 100,0 \\
\hline 1849-1859 & 6 & 35,3 & 9 & 52,9 & 2 & 11,8 & 17 & 100,0 \\
\hline $1860-1871$ & 0 & & 0 & & 0 & & 0 & \\
\hline $1805-1871$ & 42 & 18,9 & 104 & 46,8 & 76 & 34,3 & 222 & 100,0 \\
\hline
\end{tabular}

FONTES: Livros de batismos de escravos da Ilha Grande de 1805-1847 e de 1850-1861; Livro de batismos de escravos de Mambucaba, 1830-1871; Livro de batismos de escravos da Ribeira, 1824-1826; e Livro de batismos, casamentos e óbitos de escravos e de livres de Jacuecanga, 1800-1888. Convento do Carmo e Igreja de Jacuecanga, Angra dos Reis, RJ.

NOTAS: AOC=África Ocidental; ACA=África Central Atlântica; AOR=África Oriental. Em 162 cerimônias não foram informadas as procedências dos batizandos africanos e em duas cerimônias, os batizandos eram crioulos.

Mulheres da África Central Atlântica foram predominantes nos batismos, somando 49 (47,6\%), contra 28 (27,2\%) cativas da África Ocidental e 26 (25,2\%) escravas da África Oriental. Entre 1805-1815, 75,0\% das mulheres eram da África Ocidental. Entre 1816-1826, 44,4\% das escravas vinham da parte central atlântica e oriental. Nos dois subperíodos seguintes, as escravas da África Central Atlântica foram mais comuns e, nos anos de 1849-1859, as poucas cativas batizadas eram da parte ocidental e central atlântica. 
TABELA 48

Procedências dos adultos africanos batizados do sexo feminino por subperíodos.

Angra dos Reis, 1805-1871

\begin{tabular}{|c|c|c|c|c|c|c|c|c|}
\hline \multirow[t]{2}{*}{ Subperíodos } & \multicolumn{2}{|c|}{$\mathrm{AOC}$} & \multicolumn{2}{|c|}{ ACA } & \multicolumn{2}{|c|}{ AOR } & \multicolumn{2}{|c|}{ Total } \\
\hline & $\mathrm{n}^{\mathrm{o}}$ & $\%$ & $\mathrm{n}^{\mathrm{o}}$ & $\%$ & $\mathrm{n}^{\mathrm{o}}$ & $\%$ & $\mathrm{n}^{\mathrm{o}}$ & $\%$ \\
\hline $1805-1815$ & 9 & 75,0 & 3 & 25,0 & 0 & & 12 & 100,0 \\
\hline 1816-1826 & 4 & 11,2 & 16 & 44,4 & 16 & 44,4 & 36 & 100,0 \\
\hline 1827-1837 & 13 & 30,2 & 21 & 48,9 & 9 & 20,9 & 43 & 100,0 \\
\hline 1838-1848 & 0 & & 7 & 87,5 & 1 & 12,5 & 8 & 100,0 \\
\hline 1849-1859 & 2 & 50,0 & 2 & 50,0 & 0 & & 4 & 100,0 \\
\hline 1860-1871 & 0 & & 0 & & 0 & & 0 & \\
\hline $1805-1871$ & 28 & 27,2 & 49 & 47,6 & 26 & 25,2 & 103 & 100,0 \\
\hline
\end{tabular}

FONTES: Livros de batismos de escravos da Ilha Grande de 1805-1847 e de 1850-1861; Livro de batismos de escravos de Mambucaba, 1830-1871; Livro de batismos de escravos da Ribeira, 1824-1826; e Livro de batismos, casamentos e óbitos de escravos e de livres de Jacuecanga, 1800-1888. Convento do Carmo e Igreja de Jacuecanga, Angra dos Reis, RJ.

NOTAS: AOC=África Ocidental; ACA=África Central Atlântica; AOR=África Oriental. Em 48 cerimônias não havia informações acerca da origem dos adultos africanos.

Somando homens e mulheres, sobressaíram os cativos provenientes da África Central Atlântica, totalizando 153, envolvendo 104 homens e 49 mulheres. Cento e dois foram cativos embarcados dos portos da chamada África Oriental, entre 76 homens e 26 mulheres. Da África Ocidental originavam-se 70 escravos, correspondendo a 42 homens e 28 mulheres.

Indivíduos provenientes da África Central Atlântica foram superiores em números, tanto entre os homens quanto entre as mulheres. O Congo foi o local mais citado, procedência de 36 homens e 16 mulheres. Entre a África Oriental, homens e mulheres de Moçambique chegaram a 76 e 26, respectivamente. Finalmente, no caso da África Ocidental, cativos ditos como de "nação Guiné" totalizaram 45 homens e 26 mulheres ${ }^{158}$. Analisando separadamente as procedências, os batizandos de Moçambique foram a maioria, somando 101, seguidos pelos cativos da Guiné, representados por 71 cativos.

O perfil, caracterizado, em ordem decrescente por África Central Atlântica, África Oriental e, por último, África Ocidental, foi compatível com as características do movimento do tráfico de escravos, na primeira metade do século XIX.

Segundo Florentino (1995, p. 85-86), entre 1795-1830, a África Central Atlântica apresentou-se como a principal fornecedora de escravos para o Rio de Janeiro. Ao longo

${ }^{158}$ Ver anexo 1. 
dos anos, sua participação no tráfico reduziu-se, embora mantendo-se em destaque sobre as outras áreas.

Em segundo esteve a África Oriental, definida como a "grande abastecedora do porto do Rio de Janeiro depois de 1811” (FLORENTINO, 1995, p. 87), consolidando a posição da Ilha de Moçambique e dos portos do sul, em especial Quilimane (FLORENTINO, 1995, p. 87). Tal movimento foi explicado pela "relativa incapacidade dos mecanismos sociais de produção de escravos da zona congo-angolana em responder de imediato à subida da demanda do sudeste brasileiro, pelo menos na proporção sugerida pela nova conjuntura que se instalou depois de 1808” (FLORENTINO, 1995, p. 87).

Em terceiro vinha a África Ocidental que, ao longo dos anos de 1790 e 1830, teve pouca influência no tráfico rumo ao Rio de Janeiro. A proibição do tráfico de escravos ao norte da linha do Equador, em 1815 colaborou para a reduzida entrada de embarcações no porto carioca. Sobre isso, Florentino (1995, p. 86) disse que

“mesmo depois deste ano, muitos cativos da África Ocidental continuaram a entrar na província, provenientes de outras áreas do Brasil (a Bahia, por exemplo e, possivelmente, por meio de insignificante contrabando)”.

TABELA 49

Situação social de padrinhos de adultos batizados por subperíodos. Angra dos Reis, 1805-1871

\begin{tabular}{|c|c|c|c|c|c|c|c|c|}
\hline \multirow[t]{2}{*}{ Subperíodos } & \multicolumn{2}{|c|}{ Escravos } & \multicolumn{2}{|c|}{ Forros } & \multicolumn{2}{|c|}{ Livres } & \multicolumn{2}{|c|}{ Total } \\
\hline & $n^{0}$ & $\%$ & $\mathrm{n}^{0}$ & $\%$ & $\mathrm{n}^{\mathrm{o}}$ & $\%$ & $\mathrm{n}^{\mathrm{o}}$ & $\%$ \\
\hline $1805-1815$ & 15 & 53,6 & 1 & 3,6 & 12 & 42,8 & 28 & 100,0 \\
\hline 1816-1826 & 151 & 73,3 & 8 & 3,9 & 47 & 22,8 & 206 & 100,0 \\
\hline 1827-1837 & 83 & 58,0 & 20 & 14,0 & 40 & 28,0 & 143 & 100,0 \\
\hline 1838-1848 & 14 & 28,6 & 5 & 10,2 & 30 & 61,2 & 49 & 100,0 \\
\hline 1849-1859 & 60 & 74,1 & 3 & 3,7 & 18 & 22,2 & 81 & 100,0 \\
\hline 1860-1871 & 1 & 50,0 & 0 & & 1 & 50,0 & 2 & 100,0 \\
\hline 1805-1871 & 324 & 63,6 & 37 & 7,3 & 148 & 29,1 & 509 & 100,0 \\
\hline
\end{tabular}

FONTES: Livros de batismos de escravos da Ilha Grande de 1805-1847 e de 1850-1861; Livro de batismos de escravos de Mambucaba, 1830-1871; Livro de batismos de escravos da Ribeira, 1824-1826; e Livro de batismos, casamentos e óbitos de escravos e de livres de Jacuecanga, 1800-1888. Convento do Carmo e Igreja de Jacuecanga, Angra dos Reis, RJ.

NOTA: Em 18 cerimônias os padrinhos não foram citados e em 10, as referências a respeito estavam ilegíveis.

Entre 1805 e 1871, a maior parte de homens e mulheres adultos foram apadrinhados por escravos (63,6\%). Padrinhos livres e forros compareceram a, respectivamente, 29,1\% e 7,3\% das cerimônias. 
Em quase todos os subperíodos, o batismo de adultos envolveu escravos. Isso foi verdade nos anos de 1805-1837 e de 1849-1859. No período de 1860-1871, a freqüência de escravos e livres foi de 50\%, cada. Os últimos foram predominantes entre 1838-1848, representando $61,2 \%$.

Unindo os dados para os anos de 1805-1848 e de 1849-1871, encontramos 61,7\% e 73,5\% de batismos cujos protetores foram escravos. Os forros estiveram em, respectivamente, 7,9\% e 3,6\%; e os livres, em 30,3\% e 22,9\%.

Qual o papel de tal cerimônia para seus senhores? Foram eles os responsáveis pelas escolhas efetuadas quanto a padrinhos e madrinhas, pois foi pouco provável que cativos recém-chegados o fizessem.

Os adultos batizados eram, em grande parte, escravos recém-chegados não apenas a Angra, mas ao Brasil. Isto porque consideramos que o ritual do batismo desempenhava um importante papel e é por decorrência deste papel que o escravo, pouco após a chegada, era levado à pia batismal. O seu aprisionamento no continente africano, sendo arrancado do seu convívio familiar e comunitário, a espera pelo embarque e a travessia pelo Atlântico configuravam uma nova realidade para o mesmo, representando um processo de transformação em "ser escravo". Um processo que era, em sua primeira etapa, concluído pela conversão ao cristianismo e recebimento de um nome cristão ou de um santo.

Embora saibamos que uma das exigências para a participação no ritual fosse o conhecimento da doutrina católica, pouco deveria se exigir de indivíduos ainda em processo de conhecimento de sua realidade. Por acreditar nisso, consideramos que, assim que possível, os escravos eram levados à cerimônia. E pelo papel que desempenhavam, alguns senhores, responsáveis pela escolha dos padrinhos e das madrinhas, selecionaram indivíduos que considerassem aptos para completar a função do ritual, ou seja, a transformação de um recém-chegado em escravo, e, neste caso, nada melhor que fossem escravos. Escravos que poderiam ter uma importância na comunidade escrava e que contavam com a confiança de seus senhores a fim de servirem como anfitriões.

Padrinhos livres, comuns entre 1838-1848, resultaram também da preocupação senhorial com a seleção de pessoas de sua confiança, podendo vir a desempenhar o 
mesmo papel junto a seus afilhados, ou seja, como indivíduos que colaborariam na inserção do recém-chegado.

A princípio o batizando adulto não percebia a função do ritual, mas não tardaria a compreender a necessidade de adoção de laços de amizade, essenciais para a sobrevivência. Se seus padrinhos viriam, necessariamente, a tornar-se parceiros, isso dependeria de afinidades necessárias para qualquer tipo de relacionamento, mas, por certo, encontraria outros, com identidades de ordem cultural, por exemplo.

TABELA 50

Senhores de padrinhos escravos e de adultos batizados por subperíodos. Angra dos Reis, 1805-1871

\begin{tabular}{l|lr|rrr|rr}
\hline Subperíodos & \multicolumn{3}{c|}{$\begin{array}{c}\text { Senhores } \\
\text { Iguais }\end{array}$} & \multicolumn{3}{c|}{$\begin{array}{c}\text { Senhores } \\
\text { Diferentes }\end{array}$} & \multicolumn{3}{c}{ Total } \\
& $\mathrm{n}^{\text {o }}$ & $\%$ & $\mathrm{n}^{\text {o }}$ & $\%$ & $\mathrm{n}^{\text {o }}$ & $\%$ \\
\hline $1805-1815$ & 8 & 61,5 & 5 & 38,5 & 13 & 100,0 \\
$1816-1826$ & 70 & 47,9 & 76 & 52,1 & 146 & 100,0 \\
$1827-1837$ & 53 & 70,7 & 22 & 29,3 & 75 & 100,0 \\
$1838-1848$ & 11 & 78,6 & 3 & 21,4 & 14 & 100,0 \\
$1849-1859$ & 30 & 50,0 & 30 & 50,0 & 60 & 100,0 \\
$1860-1871$ & 0 & & 0 & & 0 & \\
$1805-1871$ & 172 & 55,8 & 136 & 44,2 & 308 & 100,0 \\
\hline
\end{tabular}

FONTES: Livros de batismos de escravos da Ilha Grande de 1805-1847 e de 1850-1861; Livro de batismos de escravos de Mambucaba, 1830-1871; Livro de batismos de escravos da Ribeira, 1824-1826; e Livro de batismos, casamentos e óbitos de escravos e de livres de Jacuecanga, 1800-1888. Convento do Carmo e Igreja de Jacuecanga, Angra dos Reis, RJ.

NOTA: Em 13 cerimônias os proprietários dos padrinhos não foram citados e em três, os seus nomes estavam ilegíveis.

Batizandos e padrinhos escravos pertencentes à mesma propriedade foram comuns em 55,8\% das cerimônias realizadas entre 1805 e 1871. Em 44,2\% dos batismos, afilhados e padrinhos eram de diferentes senhores.

A maior freqüência de afilhados e padrinhos de igual dono foi constante nos anos de 1805-1815 e de 1827-1848. Entre 1816-1826 houve uma ligeira predominância de apadrinhamento envolvendo cativos de diferentes propriedades e, entre 1849-1859, as variáveis "senhores iguais" e "senhores diferentes" corresponderam a 50\%, cada.

Entre 1805-1848, padrinhos e afilhados de mesma propriedade corresponderam a $57,2 \%$ e, nos anos de $1849-1871$, a 50\%. No caso de padrinhos e afilhados de diferentes senhores, encontramos, $42,7 \%$ e $50 \%$, respectivamente.

Os proprietários foram os responsáveis por selecionar os padrinhos para seus cativos. Esses padrinhos tinham como função auxiliar seus afilhados na compreensão da 
realidade de vida a que foram "jogados". Por isso, se fosse possível, melhor seria que padrinhos e afilhados pertencessem à mesma propriedade. Isto se dava porque era mais viável a convocação de um escravo seu ao comparecimento à cerimônia. Além de que, os batismos que tiveram padrinhos escravos de mesma propriedade que seus afilhados, possivelmente, eram ou médios ou grandes plantéis.

Entretanto, 44,2\% dos padrinhos escravos e seus afilhados pertenciam a senhores diferentes. Quando isso ocorria, os proprietários deveriam contar com a compreensão do proprietário do padrinho a fim de liberá-lo das funções do dia para que comparecesse ao sacramento. Os respectivos senhores poderiam, por exemplo, ser vizinhos. Isto deve ter ocorrido em diversas situações. Especulamos que os proprietários que requisitavam escravos de outros senhores eram, eles mesmos, senhores de número reduzido de trabalhadores compulsórios, pois convocariam cativos seus ao apadrinhamento.

Comparando as tabelas 49 e 50 observamos que, à proporção que aumentava o percentual de escravos como padrinhos, elevava-se a freqüência de padrinhos de senhores diferentes ao dos batizandos. Ou seja, a presença de padrinhos escravos era "alimentada" pelo convite feito a escravos de outras propriedades. Alguns dos senhores que, geralmente, batizavam cativos, poderiam dispor de pequenas escravarias, daí requisitarem cativos de outros proprietários. Para tal afirmação, partimos da constatação encontrada por Góes (1993) de que os escravos das maiores propriedades tendiam a receber padrinhos escravos de mesmo senhor ${ }^{159}$. Portanto, o aumento da incidência de afilhados e de padrinhos escravos de diferentes senhores pode ser um indício de que houve aumento da participação de pequenas propriedades.

Entre as madrinhas, nos anos de 1805-1871, as escravas foram as preferidas, respondendo por 302 (74,6\%) cerimônias. As mulheres livres estiveram em 82 (20,2\%) e as forras, em 21 (5,2\%) sacramentos.

A fim de facilitar a comparação entre a primeira e a segunda metade dos oitocentos, somamos os dados encontrados de 1805 até 1848 e de 1849 a 1871 . As escravas corresponderam a $72,2 \%$ e $89,3 \%$, respectivamente. As forras estiveram em

\footnotetext{
${ }^{159}$ A idéia lançada por Góes (1993) resultou da avaliação dos registros de batismo de escravos adultos e de crianças da freguesia de Inhaúma, no Rio de Janeiro, RJ.
} 
$5,7 \%$ e $1,8 \%$. Enquanto que as livres foram convidadas a participar de $22,1 \%$ e $8,9 \%$ das cerimônias.

\section{TABELA 51}

Situação social de madrinhas de adultos batizados por subperíodos. Angra dos Reis, 1805-1871

\begin{tabular}{|c|c|c|c|c|c|c|c|c|}
\hline \multirow[t]{2}{*}{ Subperíodos } & \multicolumn{2}{|c|}{ Escravas } & \multicolumn{2}{|c|}{ Forras } & \multicolumn{2}{|c|}{ Livres } & \multicolumn{2}{|c|}{ Total } \\
\hline & $n^{0}$ & $\%$ & $\mathrm{n}^{\mathrm{o}}$ & $\%$ & $\mathrm{n}^{\circ}$ & $\%$ & $\mathrm{n}^{\mathrm{o}}$ & $\%$ \\
\hline $1805-1815$ & 10 & 52,6 & 0 & & 9 & 47,4 & 19 & 100,0 \\
\hline 1816-1826 & 142 & 74,7 & 10 & 5,3 & 38 & 20,0 & 190 & 100,0 \\
\hline 1827-1837 & 87 & 76,3 & 10 & 8,8 & 17 & 14,9 & 114 & 100,0 \\
\hline 1838-1848 & 13 & 50,0 & 0 & & 13 & 50,0 & 26 & 100,0 \\
\hline 1849-1859 & 50 & 89,3 & 1 & 1,8 & 5 & 8,9 & 56 & 100,0 \\
\hline 1860-1871 & 0 & & 0 & & 0 & & 0 & \\
\hline $1805-1871$ & 302 & 74,6 & 21 & 5,2 & 82 & 20,2 & 405 & 100,0 \\
\hline
\end{tabular}

FONTES: Livros de batismos de escravos da Ilha Grande de 1805-1847 e de 1850-1861; Livro de batismos de escravos de Mambucaba, 1830-1871; Livro de batismos de escravos da Ribeira, 1824-1826; e Livro de batismos, casamentos e óbitos de escravos e de livres de Jacuecanga, 1800-1888. Convento do Carmo e Igreja de Jacuecanga, Angra dos Reis, RJ.

NOTA: Em 83 cerimônias as representações religiosas (santas) foram citadas, em 37 as madrinhas não foram nomeadas e em 12, seus nomes estavam ilegíveis.

Nos anos de 1805-1815, as escravas representaram 52,6\% das madrinhas, seguidas de perto pelas mulheres livres, presentes em $47,4 \%$ dos batismos. Nos anos de 1816-1837 o convite feito às cativas aumentou, chegando a 76,3\% das cerimônias, entre 1827-1837. Entretanto, entre 1838-1848 equilibrou-se os percentuais de escravas e livres, correspondendo a 50\%, cada. Com a chegada da segunda metade do século XIX, as cativas foram indicadas em $89,3 \%$ dos sacramentos.

Os percentuais de escravos como padrinhos e de madrinhas e suas evoluções ao longo dos anos foram semelhantes. Foi parecido, inclusive, a opção por padrinhos e madrinhas livres entre 1838-1848.

Entre as madrinhas, a não citação foi maior do que entre os padrinhos. As chamadas madrinhas ausentes chegaram, no total, a 37 (6,9\%), maior que os 14 , ou 2,6\%, batismos onde não foram indicados padrinhos. Isto foi uma tendência geral verificada por estudos que observam maior ausência de madrinhas, independentemente da faixa etária do batizando.

Sobre isso, Góes (1993, p. 56), em estudo sobre a freguesia de Inhaúma, considerou que "o padrinho possuía um papel de maior relevo que a madrinha. 
Independentemente de suas respectivas condições jurídicas, os homens tendiam a se fazer presentes quase duas vezes e meia a mais que as mulheres”.

\section{TABELA 52}

Representações religiosas presentes nos batismos de adultos por subperíodos. Angra dos Reis, 1805-1871

\begin{tabular}{|c|c|c|c|c|c|c|c|c|c|c|c|c|}
\hline \multirow[t]{2}{*}{ Subperíodos } & \multicolumn{2}{|c|}{ SA } & \multicolumn{2}{|c|}{ NS } & \multicolumn{2}{|c|}{ SC } & \multicolumn{2}{|c|}{ SR } & \multicolumn{2}{|c|}{$\mathrm{BD}$} & \multicolumn{2}{|c|}{ Total } \\
\hline & $\mathrm{n}^{\mathrm{o}}$ & $\%$ & $\mathrm{n}^{\mathrm{o}}$ & $\%$ & $n^{\circ}$ & $\%$ & $\mathrm{n}^{\mathrm{o}}$ & $\%$ & $\mathrm{n}^{\mathrm{o}}$ & $\%$ & $\mathrm{n}^{\mathrm{o}}$ & $\%$ \\
\hline $1805-1815$ & 4 & 100,0 & 0 & & 0 & & 0 & & 0 & & 4 & 100,0 \\
\hline 1816-1826 & 8 & 53,3 & 1 & 6,7 & 1 & 6,7 & 0 & & 5 & 33,3 & 15 & 100,0 \\
\hline 1827-1837 & 5 & 31,3 & 10 & 62,5 & 0 & & 1 & 6,2 & 0 & & 16 & 100,0 \\
\hline 1838-1848 & 0 & & 19 & 82,6 & 0 & & 4 & 17,4 & 0 & & 23 & 100,0 \\
\hline 1849-1859 & 0 & & 23 & 100,0 & 0 & & 0 & & 0 & & 23 & 100,0 \\
\hline 1860-1871 & 0 & & 2 & 100,0 & 0 & & 0 & & 0 & & 2 & 100,0 \\
\hline 1805-1871 & 17 & 20,5 & 55 & 66,3 & 1 & 1,2 & 5 & 6,0 & 5 & 6,0 & 83 & 100,0 \\
\hline
\end{tabular}

FONTES: Livros de batismos de escravos da Ilha Grande de 1805-1847 e de 1850-1861; Livro de batismos de escravos de Mambucaba, 1830-1871; Livro de batismos de escravos da Ribeira, 1824-1826; e Livro de batismos, casamentos e óbitos de escravos e de livres de Jacuecanga, 1800-1888. Convento do Carmo e Igreja de Jacuecanga, Angra dos Reis, RJ.

NOTAS: SA=Santa Ana; NS=Nossa Senhora; SC=Senhora da Conceição; SR=Senhora do Rosário; BD=Senhora do Bom Despacho.

Entre as representações religiosas, as definidas como Protetora Nossa Senhora foram as mais representativas no total, somando 55 (66,3\%). Assim como fora visto na freguesia de São José, no Rio de Janeiro, Nossa Senhora foi citada em 281 (77,2\%) sacramentos de adultos, entre 1802-1821 (FERREIRA, 2000, p. 188).

Santa Ana foi indicada em 17 (20,5\%). Foram citadas, também, Nossa Senhora do Bom Despacho e Nossa Senhora do Rosário, ambas em cinco sacramentos, correspondendo a 6,0\%, cada; e Nossa Senhora da Conceição foi apontada em uma cerimônia, ou 1,2\%.

As citações às representações religiosas estiveram vinculadas às freguesias nas quais ocorreram as cerimônias: Santa Ana foi citada em 56,6\% dos batismos da Ilha Grande, sendo ela a representação religiosa que dava nome à dita freguesia; Nossa Senhora da Conceição, apontada em 50,0\% dos sacramento da Ribeira, também era a protetora da localidade; e Nossa Senhora do Rosário, indicada em 16,1\% dos registros de Mambucaba.

Os registros de batismo que indicaram como protetoras, santas que "protegiam” as freguesias, estavam, na verdade, “ preenchendo” a lacuna referente às madrinhas. Se 
estas citações representavam algum tipo de devoção, por que não houve uma variedade de santas?

TABELA 53

Senhores de madrinhas escravas e de adultos batizados por subperíodos. Angra dos Reis, 1805-1871

\begin{tabular}{|c|c|c|c|c|c|c|}
\hline \multirow[t]{2}{*}{ Subperíodos } & \multicolumn{2}{|c|}{$\begin{array}{c}\text { Senhores } \\
\text { Iguais }\end{array}$} & \multicolumn{2}{|c|}{$\begin{array}{c}\text { Senhores } \\
\text { Diferentes }\end{array}$} & \multicolumn{2}{|c|}{ Total } \\
\hline & $\mathrm{n}^{\mathrm{o}}$ & $\%$ & $\mathrm{n}^{\mathrm{o}}$ & $\%$ & $\mathrm{n}^{\mathrm{o}}$ & $\%$ \\
\hline 1805-1815 & 4 & 44,4 & 5 & 55,6 & 9 & $\overline{100,0}$ \\
\hline 1816-1826 & 61 & 43,9 & 78 & 56,1 & 139 & 100,0 \\
\hline 1827-1837 & 58 & 73,4 & 21 & 26,6 & 79 & 100,0 \\
\hline $1838-1848$ & 10 & 76,9 & 3 & 23,1 & 13 & 100,0 \\
\hline 1849-1859 & 25 & 50,0 & 25 & 50,0 & 50 & 100,0 \\
\hline 1860-1871 & 0 & & 0 & & 0 & \\
\hline 1805-1871 & 158 & 54,5 & 132 & 45,5 & 290 & 100,0 \\
\hline
\end{tabular}

FONTES: Livros de batismos de escravos da Ilha Grande de 1805-1847 e de 1850-1861; Livro de batismos de escravos de Mambucaba, 1830-1871; Livro de batismos de escravos da Ribeira, 1824-1826; e Livro de batismos, casamentos e óbitos de escravos e de livres de Jacuecanga, 1800-1888. Convento do Carmo e Igreja de Jacuecanga, Angra dos Reis, RJ.

NOTA: Em nove cerimônias os proprietários das madrinhas estavam ausentes e em três, seus nomes estavam ilegíveis.

Nos anos de 1805 a 1871, 158 (54,5\%) madrinhas escravas e afilhados pertenceram aos mesmos senhores, enquanto em 132 (45,5\%) batismos, as madrinhas e seus afilhados viviam em propriedades diferentes. Batizandos e madrinhas cativas de diferentes proprietários tiveram um ligeiro predomínio nos anos de 1805 até 1826. De 1827 até 1848, afilhados e madrinhas de iguais senhores foram comuns em torno de 60\%. Entre 1849-1859, correspondeu a 50\%.

O movimento verificado permite afirmar a existência de um processo "semelhante" quanto a opção por padrinhos e madrinhas escravos entre 1805-1815 e 1816-1826. Houve diferenças em 1816-1826, quando existiu maior freqüência de madrinhas e menor de padrinhos. Entre 1816-1826 e 1827-1837, ambos diminuíram e, entre 1849 e 1859, aumentaram.

No entanto, entre 1805-1848 e 1849-1871, afilhados e madrinhas de propriedades iguais compreenderam 55,4\% e 50\%, respectivamente. Os afilhados e madrinhas de senhores diferentes chegaram a $44,6 \%$ e $50 \%$.

Quando os padrinhos e madrinhas livres foram predominantes, entre 1838-1848, os escravos de propriedades iguais foram mais freqüentes. 
No geral, padrinhos e madrinhas escravos foram os mais comuns entre os batismos de adultos e, acompanhando o aumento percentual dos mesmos, entre a primeira e a segunda metade do século XIX, elevou-se a participação de protetores escravos de senhores diferentes aos dos batizandos. Conseqüentemente, ou grande parte dos proprietários deveriam ser pequenos escravistas, ou a redução do número de cativos nos plantéis acabou conduzindo os senhores de batizandos a buscar padrinhos e madrinhas em outras propriedades.

Portanto, o batismo de adultos foi um evento, preferencialmente, de escravos homens africanos, com percentual maior daqueles da África Central Atlântica. A partir da avaliação das procedências, separadamente, observamos uma relativa representatividade de cativos definidos como de Moçambique, referente à África Oriental, e da Guiné, África Ocidental.

A freqüência de batismos de homens e de uma minoria constituída por mulheres diminuiu ao longo dos anos. Tal movimento decrescente resultou do término do tráfico externo de escravos e, conseqüentemente, do fim da entrada de cativos pagãos no município.

Os batizandos adultos participaram de cerimônias nas quais seus proprietários desempenharam a função de selecionar padrinhos e madrinhas. Esses, independentemente do subperíodo analisado, corresponderam a, preferencialmente, cativos que, além de igual situação social, foram, muitas vezes, da mesma propriedade que seus afilhados.

O ritual do batismo foi uma das etapas de formação do "ser escravo" e um momento em que o recém-chegado, além de receber um nome cristão e se converter ao catolicismo, recebia padrinhos e madrinhas que respondiam pela inserção do mesmo na sociedade escravista. Para tal, se fosse possível, seriam de igual propriedade que seus afilhados, caso contrário os senhores dos batizandos recorriam às outras escravarias.

Ao longo dos anos, em meio a diminuição de adultos na qualidade de batizandos, houve um aumento de padrinhos e de madrinhas escravos, acompanhado pela elevação percentual daqueles que viviam em outras propriedades.

Em menor número houve cerimônias onde participaram padrinhos e madrinhas livres. Estes foram facilitados por relações de parentesco, de amizade e de vizinhança existentes entre os senhores. 
E no caso das crianças, quais as características dos laços de apadrinhamento e de compadrio? 


\section{CAPÍTULO 9-BATISMO DE CRIANÇAS ESCRAVAS E INGÊNUAS}

O batismo de crianças possuía uma lógica diversa àquela do sacramento que envolvia os adultos. Ele criava um duplo laço, o de compadrio, envolvendo os pais e os padrinhos, e o de apadrinhamento, celebrando a associação entre batizandos e padrinhos. Laço que resultava de escolhas efetuadas pelos pais dos batizandos. Escolhas que definiam estratégias, objetivos que variavam de acordo com os participantes, suas situações sociais e a legitimidade dos batizandos. Correspondeu a um vínculo que, além de selecionar "pais espirituais", criava e reforçava amizades, solidariedades e conhecimentos. Entretanto, não podemos descartar a possibilidade de interferência senhorial também neste momento.

Nas fontes, a criança ilegítima foi identificada a partir da definição filho "natural”, "pai incógnito" ou de mãe solteira. As crianças legítimas, por sua vez, corresponderam aos batizandos que tiveram a indicação de seus pais, deixando implícito tratar-se de casais unidos perante a Igreja. Desta forma, quando falamos em comportamentos dos pais, estamos trabalhando com famílias formadas pelo sacramento do casamento. Possivelmente, muitos destes casais estavam inseridos em plantéis de médio a grande porte, tanto na primeira quanto na segunda metade do oitocentos. Quando tratamos de mães solteiras, correspondem às mulheres que se tornaram mães sem ter passado pela união legal, resultando o filho de relação de caráter consensual ou acidental Tais mulheres, na primeira metade do século foram comuns, principalmente, nas pequenas propriedades e, na segunda metade, freqüentes em todas as faixas de tamanho de propriedades (FTP) ${ }^{160}$.

\footnotetext{
${ }^{160}$ Ver capítulo 3.
} 
TABELA 54

Legitimidade das crianças escravas e ingênuas batizadas por subperíodos. Angra dos Reis, 1805-1888

\begin{tabular}{l|lr|lr|rr}
\hline Subperíodos & \multicolumn{2}{|c|}{ Legítimas } & \multicolumn{2}{c|}{ Ilegítimas } & \multicolumn{2}{|c}{ Total } \\
& $\mathrm{n}^{\mathrm{o}}$ & $\%$ & $\mathrm{n}^{\mathrm{o}}$ & $\%$ & $\mathrm{n}^{\mathrm{0}}$ & $\%$ \\
\hline $1805-1815$ & 100 & 37,5 & 167 & 62,5 & 267 & 100,0 \\
$1816-1826$ & 167 & 32,6 & 346 & 67,4 & 513 & 100,0 \\
$1827-1837$ & 178 & 32,9 & 363 & 67,1 & 541 & 100,0 \\
$1838-1848$ & 78 & 23,0 & 261 & 77,0 & 339 & 100,0 \\
$1849-1859$ & 186 & 16,6 & 934 & 83,4 & 1.120 & 100,0 \\
$1860-1871$ & 33 & 7,6 & 402 & 92,4 & 435 & 100,0 \\
$1872-1888$ & 52 & 13,2 & 342 & 86,8 & 394 & 100,0 \\
$1805-1888$ & 794 & 22,0 & 2.815 & 78,0 & 3.609 & 100,0 \\
\hline
\end{tabular}

FONTES: Livros de batismos de escravos da Ilha Grande de 1805-1847 e de 1850-1861; Livro de batismos de ingênuos da Ilha Grande, 1872-1888; Livro de batismos de escravos de Mambucaba, 1830-1871; Livro de batismos de escravos da Ribeira, 1824-1826; e Livro de batismos, casamentos e óbitos de escravos e de livres de Jacuecanga, 18001888. Convento do Carmo e Igreja de Jacuecanga, Angra dos Reis, RJ.

NOTA: Em 23 cerimônias não foi possível identificar o grau de legitimidade.

As crianças ilegítimas estiveram presentes em 2.815 (78,0\%) sacramentos, enquanto as legítimas compareceram a 794 (22,0\%) batismos. Em todos os subperíodos, as crianças ilegítimas foram a maioria. Podemos, inclusive, dizer que houve um movimento ascendente no percentual de naturais até chegar ao subperíodo de 1872-1888, quando houve uma pequena queda, chegando a $86,8 \%$.

O aumento da participação de crianças ilegítimas, em geral, resultou da diminuição de famílias legitimadas pelo casamento e, em oposição, do crescimento de famílias encabeçadas por mães solteiras.

O percentual encontrado para Angra, nos anos anteriores a 1850, foi menor que o localizado para Inhaúma, freguesia rural do Rio de Janeiro, entre 1817-1842. As crianças naturais representaram, naquela freguesia, 887 (79,3\%) batizandos (GÓES, 1993, p. 59). Foi abaixo das 3.293 (93,2\%) crianças ilegítimas presentes na pia batismal, na freguesia urbana de São José, no Rio de Janeiro, entre 1802-1821 (FERREIRA, 2000, p. 147). E em quatro paróquias rurais do Recôncavo Baiano, entre 1723-1816, grande parte das crianças eram filhas de pais não casados, segundo a Igreja (SCHWARTZ, 1995, p. 318). 
TABELA 55

Sazonalidade das cerimônias de batismos de crianças e ingênuas legítimas por subperíodos. Angra dos Reis, 1805-1888

\begin{tabular}{|c|c|c|c|c|c|c|c|c|}
\hline Mês & $\begin{array}{c}1805-1815 \\
n^{\circ}(\%)\end{array}$ & $\begin{array}{c}1816-1826 \\
n^{\circ}(\%)\end{array}$ & $\begin{array}{c}1827-1837 \\
n^{\circ}(\%)\end{array}$ & $\begin{array}{c}1838-1848 \\
n^{\circ}(\%)\end{array}$ & $\begin{array}{c}1849-1859 \\
n^{\circ}(\%)\end{array}$ & $\begin{array}{c}1860-1871 \\
n^{\circ}(\%)\end{array}$ & $\begin{array}{c}1872-1888 \\
n^{\circ}(\%)\end{array}$ & $\begin{array}{c}1805-1888 \\
n^{\circ}(\%)\end{array}$ \\
\hline Janeiro & $10(10,1)$ & $5(3,0)$ & $11(6,2)$ & $11(14,1)$ & $9(4,8)$ & $8(24,0)$ & $5(9,6)$ & $59(7,4)$ \\
\hline Fevereiro & $6(6,1)$ & $9(5,4)$ & $10(5,6)$ & $3(3,8)$ & $16(8,5)$ & 0 & $4(7,7)$ & $48(6,1)$ \\
\hline Março & $5(5,0)$ & $21(12,6)$ & $12(6,8)$ & $3(3,8)$ & $9(4,8)$ & $3(9,1)$ & $4(7,7)$ & $57(7,2)$ \\
\hline Abril & $4(4,0)$ & $13(7,8)$ & $20(11,3)$ & $8(10,3)$ & $6(3,2)$ & $5(15,3)$ & $8(15,4)$ & $64(8,1)$ \\
\hline Maio & $12(12,1)$ & $9(5,4)$ & $16(9,0)$ & $5(6,5)$ & $22(11,8)$ & $4(12,1)$ & $5(9,6)$ & $73(9,2)$ \\
\hline Junho & $12(12,1)$ & $15(8,9)$ & $26(14,8)$ & $6(7,7)$ & $24(12,8)$ & $2(6,1)$ & $5(9,6)$ & $90(11,3)$ \\
\hline $1^{\circ}$ semestre & $49(49,5)$ & $72(43,1)$ & $95(53,7)$ & $36(46,2)$ & $86(46,0)$ & $22(66,7)$ & $31(59,6)$ & $391(49,3)$ \\
\hline Julho & $6(6,1)$ & $20(11,9)$ & $22(12,4)$ & $5(6,5)$ & $13(6,9)$ & $2(6,1)$ & $5(9,6)$ & $73(9,2)$ \\
\hline Agosto & $11(11,1)$ & $18(10,8)$ & $14(7,9)$ & $9(11,5)$ & $19(10,2)$ & $2(6,1)$ & $5(9,6)$ & $78(9,9)$ \\
\hline Setembro & $12(12,1)$ & $14(8,4)$ & $9(5,2)$ & $3(3,8)$ & $14(7,5)$ & $3(9,1)$ & $4(7,7)$ & $59(7,4)$ \\
\hline Outubro & $12(12,1)$ & $16(9,6)$ & $10(5,6)$ & $9(11,5)$ & $12(6,4)$ & 0 & $1(1,9)$ & $60(7,6)$ \\
\hline Novembro & $2(2,1)$ & $16(9,6)$ & $6(3,4)$ & $7(9,0)$ & $12(6,4)$ & $1(3,0)$ & $2(3,9)$ & $46(5,8)$ \\
\hline Dezembro & $7(7,1)$ & $11(6,6)$ & $21(11,8)$ & $9(11,5)$ & $31(16,6)$ & $3(9,1)$ & $4(7,7)$ & $86(10,8)$ \\
\hline $2^{\circ}$ semestre & $50(50,5)$ & $95(56,9)$ & $82(46,3)$ & $42(53,8)$ & $101(54,0)$ & $11(33,3)$ & $21(40,4)$ & $402(50,7)$ \\
\hline Total & $99(100,0)$ & $167(100,0)$ & $177(100,0)$ & $78(100,0)$ & $187(100,0)$ & $33(100,0)$ & $52(100,0)$ & $793(100,0)$ \\
\hline
\end{tabular}

FONTES: Livro de casamentos de escravos de Mambucaba, 1830-1875; Livro de casamentos de escravos da Ribeira, 1851-1886; e Livro de casamentos de escravos da Ilha Grande, 1851-1875. Convento do Carmo e Igreja de Jacuecanga, Angra dos Reis, RJ.

NOTA: Uma cerimônia não foi contabilizada por falta de informações.

Quanto aos meses em que ocorriam os batismos, não havia uma preferência. Existia um equilíbrio entre os primeiros e últimos seis meses, destacando-se os meses de junho e de dezembro. Não tendo, portanto, nenhuma relação com os calendários agrícola e religioso.

Os meses nos quais as crianças compareceram, em menor número na pia batismal, foram fevereiro e novembro.

O mês de fevereiro, além de ser de menor número de batismos, foi também o período em que as mulheres casadas e solteiras menos conceberam seus filhos. Fica a questão: o que havia no mês de fevereiro? 
TABELA 56

Sazonalidade das cerimônias de batismos de crianças e ingênuas ilegítimas por subperíodos.

Angra dos Reis, 1805-1888

\begin{tabular}{|c|c|c|c|c|c|c|c|c|}
\hline Mês & $\begin{array}{c}1805-1815 \\
n^{\circ}(\%)\end{array}$ & $\begin{array}{c}1816-1826 \\
n^{\circ}(\%)\end{array}$ & $\begin{array}{c}1827-1837 \\
n^{\circ}(\%)\end{array}$ & $\begin{array}{c}1838-1848 \\
n^{\circ}(\%)\end{array}$ & $\begin{array}{c}1849-1859 \\
n^{\circ}(\%)\end{array}$ & $\begin{array}{c}1860-1871 \\
n^{\circ}(\%)\end{array}$ & $\begin{array}{c}1872-1888 \\
n^{\circ}(\%)\end{array}$ & $\begin{array}{c}1805-1888 \\
n^{\circ}(\%)\end{array}$ \\
\hline Janeiro & $8(4,8)$ & $17(4,9)$ & $33(9,1)$ & $23(8,8)$ & $70(7,6)$ & $58(14,4)$ & $36(10,5)$ & $245(8,7)$ \\
\hline Fevereiro & $6(3,6)$ & $25(7,2)$ & $24(6,6)$ & $22(8,4)$ & $70(7,6)$ & $32(7,9)$ & $16(4,7)$ & $195(6,9)$ \\
\hline Março & $16(9,6)$ & $41(11,9)$ & $29(8,0)$ & $13(5,0)$ & $54(5,8)$ & $23(5,7)$ & $20(5,9)$ & $196(7,0)$ \\
\hline Abril & $11(6,6)$ & $35(10,2)$ & $36(9,9)$ & $19(7,3)$ & $65(6,9)$ & $45(11,2)$ & $25(7,3)$ & $236(8,4)$ \\
\hline Maio & $24(14,4)$ & $23(6,7)$ & $29(8,0)$ & $20(7,7)$ & $62(6,6)$ & $27(6,7)$ & $34(9,9)$ & $219(7,8)$ \\
\hline Junho & $20(11,9)$ & $30(8,7)$ & $40(11,0)$ & $25(9,6)$ & $112(12,0)$ & $64(15,9)$ & $28(8,2)$ & $319(11,3)$ \\
\hline $1^{\circ}$ semestre & $85(50,9)$ & $171(49,6)$ & $191(52,6)$ & $122(46,7)$ & $433(46,5)$ & $249(61,9)$ & $159(46,6)$ & $1.410(50,2)$ \\
\hline Julho & $11(6,6)$ & $28(8,1)$ & $41(11,3)$ & $20(7,7)$ & $107(11,5)$ & $30(7,5)$ & $32(9,4)$ & $269(9,6)$ \\
\hline Agosto & $22(13,2)$ & $35(10,2)$ & $21(5,8)$ & $14(5,4)$ & $60(6,4)$ & $26(6,7)$ & $34(10,0)$ & $212(7,5)$ \\
\hline Setembro & $20(11,9)$ & $29(8,4)$ & $14(3,8)$ & $25(9,6)$ & $73(7,8)$ & $24(5,9)$ & $25(7,3)$ & $210(7,5)$ \\
\hline Outubro & $10(5,9)$ & $26(7,5)$ & $20(5,5)$ & $15(5,7)$ & $72(7,7)$ & $36(8,9)$ & $28(8,2)$ & $207(7,4)$ \\
\hline Novembro & $11(6,6)$ & $27(7,8)$ & $24(6,6)$ & $15(5,7)$ & $61(6,6)$ & $23(5,7)$ & $28(8,2)$ & $189(6,7)$ \\
\hline Dezembro & $8(4,8)$ & $29(8,4)$ & $52(14,4)$ & $50(19,1)$ & $126(13,5)$ & $14(3,5)$ & $35(10,3)$ & $314(11,2)$ \\
\hline $2^{\mathbf{o}}$ semestre & $82(49,6)$ & $174(50,4)$ & $172(47,4)$ & $139(53,3)$ & $499(53,5)$ & $153(38,1)$ & $182(53,4)$ & $1.401(49,8)$ \\
\hline Total & $167(100,0)$ & $345(100,0)$ & $363(100,0)$ & $261(100,0)$ & $932(100,0)$ & $402(100,0)$ & $341(100,0)$ & $2.811(100,0)$ \\
\hline
\end{tabular}

FONTES: Livro de casamentos de escravos de Mambucaba, 1830-1875; Livro de casamentos de escravos da Ribeira, 1851-1886; e Livro de casamentos de escravos da Ilha Grande, 1851-1875. Convento do Carmo e Igreja de Jacuecanga, Angra dos Reis, RJ.

NOTA: Em quatro cerimônias não havia informações suficientes.

Entre as crianças ilegítimas também houve um equilíbrio entre as cerimônias ocorridas no primeiro e segundo semestres. Também aqui, os naturais foram batizados principalmente nos meses de junho e de dezembro. E, mais uma vez, os meses de fevereiro e novembro, foram aqueles em que menor número de crianças compareceram às cerimônias. 
TABELA 57

Sexo das crianças escravas e ingênuas legítimas batizadas por subperíodos. Angra dos Reis, 1805-1888

\begin{tabular}{r|rr|rr|rr}
\hline Subperíodos & \multicolumn{2}{|c|}{ Masculino } & \multicolumn{2}{c|}{ Feminino } & \multicolumn{3}{c}{ Total } \\
& $\mathrm{n}^{\mathrm{o}}$ & $\%$ & $\mathrm{n}^{\mathrm{o}}$ & $\%$ & $\mathrm{n}^{\mathrm{o}}$ & $\%$ \\
\hline $1805-1815$ & 51 & 51,0 & 49 & 49,0 & 100 & 100,0 \\
$1816-1826$ & 80 & 48,2 & 86 & 51,8 & 166 & 100,0 \\
$1827-1837$ & 87 & 49,2 & 90 & 50,8 & 177 & 100,0 \\
$1838-1848$ & 48 & 61,5 & 30 & 38,5 & 78 & 100,0 \\
$1849-1859$ & 89 & 48,4 & 95 & 51,6 & 184 & 100,0 \\
$1860-1871$ & 17 & 51,5 & 16 & 48,5 & 33 & 100,0 \\
$1872-1888$ & 33 & 63,5 & 19 & 36,5 & 52 & 100,0 \\
$1805-1888$ & 405 & 51,3 & 385 & 48,7 & 790 & 100,0 \\
\hline
\end{tabular}

FONTES: Livros de batismos de escravos da Ilha Grande de 1805-1847 e de 1850-1861; Livro de batismos de ingênuos da Ilha Grande, 1872-1888; Livro de batismos de escravos de Mambucaba, 1830-1871; Livro de batismos de escravos da Ribeira, 1824-1826; e Livro de batismos, casamentos e óbitos de escravos e de livres de Jacuecanga, 18001888. Convento do Carmo e Igreja de Jacuecanga, Angra dos Reis, RJ.

NOTA: Em quatro cerimônias não conseguimos identificar o sexo dos batizandos.

Entre as crianças legítimas houve um equilíbrio sexual. Isto resultou da reprodução natural, diferentemente do que ocorreu entre os escravos adultos batizados, com grande presença masculina. Ambos perfis apontam para duas demografias específicas, embora presentes na realidade escravista. Não foi por menos que, tanto entre os legítimos quanto entre os ilegítimos, a participação dos sexos feminino e masculino foram equivalentes.

TABELA 58

Sexo das crianças escravas e ingênuas ilegítimas batizadas por subperíodos. Angra dos Reis, 1805-1888

\begin{tabular}{l|lr|cc|cr}
\hline Subperíodos & \multicolumn{2}{|c|}{ Masculino } & \multicolumn{2}{c|}{ Feminino } & \multicolumn{3}{c}{ Total } \\
& $\mathrm{n}^{\mathrm{o}}$ & $\%$ & $\mathrm{n}^{\mathrm{o}}$ & $\%$ & $\mathrm{n}^{\mathrm{o}}$ & $\%$ \\
\hline $1805-1815$ & 86 & 52,7 & 77 & 47,3 & 163 & 100,0 \\
$1816-1826$ & 169 & 48,8 & 177 & 51,2 & 346 & 100,0 \\
$1827-1837$ & 186 & 51,2 & 177 & 48,8 & 363 & 100,0 \\
$1838-1848$ & 127 & 48,8 & 133 & 51,2 & 260 & 100,0 \\
$1849-1859$ & 500 & 53,5 & 434 & 46,5 & 934 & 100,0 \\
$1860-1871$ & 194 & 48,4 & 207 & 51,6 & 401 & 100,0 \\
$1872-1888$ & 161 & 47,2 & 180 & 52,8 & 341 & 100,0 \\
$1805-1888$ & 1.423 & 50,7 & 1.385 & 49,3 & 2.808 & 100,0 \\
\hline
\end{tabular}

FONTES: Livros de batismos de escravos da Ilha Grande de 1805-1847 e de 1850-1861; Livro de batismos de ingênuos da Ilha Grande, 1872-1888; Livro de batismos de escravos de Mambucaba, 1830-1871; Livro de batismos de escravos da Ribeira, 1824-1826; e Livro de batismos, casamentos e óbitos de escravos e de livres de Jacuecanga, 18001888. Convento do Carmo e Igreja de Jacuecanga, Angra dos Reis, RJ.

NOTA: Em sete cerimônias não foram indicados o sexo dos escravos. 
Sampaio (1994, p. 142), em estudo sobre Magé, província do Rio de Janeiro, na segunda metade do século XIX, reconheceu a existência de uma "demografia dos escravos”, caracterizada pela reprodução natural positiva, baseando-se em relações estabelecidas pelos escravos no interior de suas comunidades, mediante casamento, uniões consensuais e o compadrio. Ao lado daquela havia uma "demografia de agricultura escravista”, assinalada pela reprodução via mercado.

Portanto, estamos diante da “demografia dos escravos”, definida pela reprodução natural, levando, conseqüentemente, a um equilíbrio entre os sexos.

\section{TABELA 59}

Idades em meses das crianças escravas e ingênuas legítimas quando do batismo por subperíodos. Angra dos Reis, 1805-1888

\begin{tabular}{c|c|c|c|c|c|c|c|c|c}
\hline Subperíodos & $\begin{array}{c}1-6 \\
\mathrm{n}^{\mathrm{o}}(\%)\end{array}$ & $\begin{array}{c}7-12 \\
\mathrm{n}^{\mathrm{o}}(\%)\end{array}$ & $\begin{array}{c}13-18 \\
\mathrm{n}^{\mathrm{o}}(\%)\end{array}$ & $\begin{array}{c}19-24 \\
\mathrm{n}^{\circ}(\%)\end{array}$ & $\begin{array}{c}25-30 \\
\mathrm{n}^{\circ}(\%)\end{array}$ & $\begin{array}{c}31-36 \\
\mathrm{n}^{\circ}(\%)\end{array}$ & $\begin{array}{c}37-42 \\
\mathrm{n}^{\circ}(\%)\end{array}$ & $\begin{array}{c}43 \text { ou mais } \\
\mathrm{n}^{\circ}(\%)\end{array}$ & $\begin{array}{c}\text { Total } \\
\mathrm{n}^{\circ}(\%)\end{array}$ \\
\hline $1805-1815$ & $77(86,5)$ & $10(11,2)$ & $2(2,3)$ & 0 & 0 & 0 & 0 & 0 & $89(100,0)$ \\
$1816-1826$ & $144(96,6)$ & $5(3,4)$ & 0 & 0 & 0 & 0 & 0 & 0 & $149(100,0)$ \\
$1827-1837$ & $142(89,9)$ & $14(8,9)$ & $1(0,6)$ & $1(0,6)$ & 0 & 0 & 0 & 0 & $158(100,0)$ \\
$1838-1848$ & $50(86,2)$ & $4(6,9)$ & $4(6,9)$ & 0 & 0 & 0 & 0 & 0 & $58(100,0)$ \\
$1849-1859$ & $131(71,2)$ & $31(16,9)$ & $11(6,0)$ & $4(2,2)$ & 0 & $3(1,6)$ & $1(0,5)$ & $3(1,6)$ & $184(100,0)$ \\
$1860-1871$ & $21(67,7)$ & $4(12,9)$ & $3(9,7)$ & $2(6,5)$ & 0 & 0 & 0 & $1(3,2)$ & $31(100,0)$ \\
$1872-1888$ & $44(86,3)$ & $6(11,8)$ & 0 & 0 & $1(1,9)$ & 0 & 0 & 0 & $51(100,0)$ \\
$1805-1888$ & $609(84,6)$ & $74(10,3)$ & $21(2,9)$ & $7(1,0)$ & $1(0,1)$ & $3(0,4)$ & $1(0,1)$ & $4(0,6)$ & $720(100,0)$ \\
\hline
\end{tabular}

FONTES: Livros de batismos de escravos da Ilha Grande de 1805-1847 e de 1850-1861; Livro de batismos de ingênuos da Ilha Grande, 1872-1888; Livro de batismos de escravos de Mambucaba de 1830-1871; Livro de batismos de escravos da Ribeira, 1824-1826; e Livro de batismos, de casamentos e de óbitos de escravos e de livres de Jacuecanga, 1800-1888.

NOTA: Em 74 cerimônias não havia informações.

Informações relativas à data de nascimento ou tempo de vida dos batizandos foram encontradas em 93,1\% dos batismos, permitindo, assim, a verificação do intervalo de tempo entre o nascimento das crianças e o seu batismo.

Entre os legítimos, 84,6\% das crianças foram batizadas até os seis meses de vida. Um percentual menor foi encontrado entre os ilegítimos, onde 74,9\% dos naturais foram batizados nos seus seis primeiros meses. A freqüência maior entre os legítimos leva a crer que a estabilidade familiar facilitava o acesso ao batismo. 
TABELA 60

Idades em meses das crianças escravas e ingênuas ilegítimas quando do batismo por subperíodos. Angra dos Reis, 1805-1888

\begin{tabular}{c|c|c|c|c|c|c|c|c|c}
\hline Subperíodos & $\begin{array}{c}1-6 \\
\mathrm{n}^{\mathrm{o}}(\%)\end{array}$ & $\begin{array}{c}7-12 \\
\mathrm{n}^{\mathrm{o}}(\%)\end{array}$ & $\begin{array}{c}13-18 \\
\mathrm{n}^{\mathrm{o}}(\%)\end{array}$ & $\begin{array}{c}19-24 \\
\mathrm{n}^{\circ}(\%)\end{array}$ & $\begin{array}{c}25-30 \\
\mathrm{n}^{\circ}(\%)\end{array}$ & $\begin{array}{c}31-36 \\
\mathrm{n}^{\circ}(\%)\end{array}$ & $\begin{array}{c}37-42 \\
\mathrm{n}^{\circ}(\%)\end{array}$ & $\begin{array}{c}43 \text { ou mais } \\
\mathrm{n}^{\circ}(\%)\end{array}$ & $\begin{array}{c}\text { Total } \\
\mathrm{n}^{\circ}(\%)\end{array}$ \\
\hline $1805-1815$ & $129(87,2)$ & $17(11,5)$ & $2(1,3)$ & 0 & 0 & 0 & 0 & 0 & $148(100,0)$ \\
$1816-1826$ & $313(97,2)$ & $8(2,5)$ & 0 & 0 & 0 & 0 & 0 & $1(0,3)$ & $322(100,0)$ \\
$1827-1837$ & $287(90,3)$ & $25(7,9)$ & $3(0,9)$ & $1(0,3)$ & 0 & $1(0,3)$ & 0 & $1(0,3)$ & $318(100,0)$ \\
$1838-1848$ & $162(77,6)$ & $26(12,4)$ & $9(4,3)$ & $4(1,9)$ & 0 & $1(0,5)$ & 0 & $7(3,3)$ & $209(100,0)$ \\
$1849-1859$ & $578(63,8)$ & $191(21,1)$ & $47(5,2)$ & $38(4,2)$ & $8(0,9)$ & $13(1,4)$ & $6(0,7)$ & $25(2,7)$ & $906(100,0)$ \\
$1860-1871$ & $219(55,0)$ & $111(27,9)$ & $29(7,3)$ & $17(4,3)$ & $1(0,2)$ & $9(2,3)$ & $2(0,5)$ & $10(2,5)$ & $398(100,0)$ \\
$1872-1888$ & $289(85,5)$ & $42(12,4)$ & $4(1,2)$ & $2(0,6)$ & 0 & 0 & 0 & $1(0,3)$ & $338(100,0)$ \\
$1805-1888$ & $1977(74,9)$ & $420(15,9)$ & $94(3,6)$ & $62(2,3)$ & $9(0,3)$ & $24(0,9)$ & $8(0,3)$ & $45(1,8)$ & $2.639(100,0)$ \\
\hline
\end{tabular}

FONTES: Livros de batismos de escravos da Ilha Grande de 1805-1847 e de 1850-1861; Livro de batismos de ingênuos da Ilha Grande, 1872-1888; Livro de batismos de escravos de Mambucaba de 1830-1871; Livro de batismos de escravos da Ribeira, 1824-1826; e Livro de batismos, de casamentos e de óbitos de escravos e de livres de Jacuecanga, 1800-1888.

NOTA: Em 176 cerimônias não foram oferecidas informações.

Entre 1805-1871 houve uma oscilação das crianças legítimas batizadas até os seis meses, o mesmo ocorrendo entre os naturais.

Após 1871, ocorreu um aumento percentual do batismo de crianças com até seis meses, resultado da necessidade encontrada, principalmente entre os escravos, de registrar seus filhos como nascidos após a Lei do Ventre Livre, ou seja, como libertos. O registro de batismo desempenhava, como dissemos, funções de reconhecimento da maternidade, da paternidade e de posse do senhor. No caso dos ingênuos, reconhecimento de maternidade, de paternidade, quando fosse o caso, mas, e principalmente, de que o pequeno era livre pela Lei de 1871.

Devido à alta taxa de mortalidade infantil, o batismo foi buscado tão logo fosse possível o comparecimento do recém-nascido à cerimônia. Desta forma, evitava-se a morte daquele sem a devida conversão ao cristianismo, permitindo-lhe a entrada no reino dos céus (LEBRUN, 1998, p. 89). Diante desta preocupação, a maior parte das crianças foi batizada até os seis meses de vida.

Tal preocupação foi vista nos batismos “em perigo de vida”, ministrados aos recém-nascidos, buscando a rápida conversão dos mesmos. Foram batismos realizados às pressas, muitas vezes em residências e sem a presença de padrinhos e madrinhas. De seis casos localizados, o batismo de Manoel, de um mês, em Jacuecanga, é um bom exemplo. 
O pequeno foi batizado em 1861, em residência de seu proprietário, o Comendador Manoel Teixeira da Cunha, não havendo a nomeação de padrinho ou de madrinha. No registro encontramos a observação, "batizado em casa em perigo de vida"161.

E qual a preferência de pais e mães no momento da escolha por padrinhos e madrinhas? O que poderia estar por trás das opções feitas?

Entre as crianças legítimas existiu um ligeiro predomínio de padrinhos escravos, correspondendo a 51\%, entre 1805-1888. Os livres foram citados em $42 \%$ das cerimônias, e os forros, em 7,0\%.

Na maior parte dos subperíodos, os escravos foram predominantes, com exceção dos anos de 1805-1815, 1827-1837 e de 1872-1888.

Se dividirmos os dados para a primeira e segunda metade do século, notamos que: os escravos estiveram em 47,3\% dos registros até 1848 e de 1849 em diante, compareceram a 58,1\% dos sacramentos. Os forros estiveram em, respectivamente, 7,0\% e 6,7\%; e os livres, em 45,6\% e 35,2\%.

Ou seja, paralelamente à diminuição numérica de escravos em Angra, em decorrência de vendas, alforrias, mortes e fugas, os pais preocuparam-se, cada vez mais, em convidar escravos para se tornarem seus compadres. Estavam eles preocupados em garantir "pais espirituais" que poderiam auxiliar na criação de seus filhos.

Na medida em que se caminhava para a segunda metade do século XIX, os escravos tenderam a ser mais representativos, diminuindo entre 1860 e 1888.

\footnotetext{
${ }^{161}$ Livro de batismos, de casamentos e de óbitos de livres e escravos de Jacuecanga, 1800-1871. Igreja de Jacuecanga, Angra dos Reis, RJ.
} 
TABELA 61

Situação social de padrinhos de crianças escravas e ingênuas legítimas por subperíodos.

Angra dos Reis, 1805-1888

\begin{tabular}{r|lr|lr|rrr|rr}
\hline Subperíodos & \multicolumn{2}{|c|}{ Escravos } & \multicolumn{3}{c|}{ Forros } & \multicolumn{3}{c}{ Livres } & \multicolumn{3}{c}{ Total } \\
& $\mathrm{n}^{\mathrm{o}}$ & $\%$ & $\mathrm{~N}^{\mathrm{o}}$ & $\%$ & $\mathrm{n}^{\mathrm{o}}$ & $\%$ & $\mathrm{n}^{\mathrm{o}}$ & 100,0 \\
\hline $1805-1815$ & 36 & 37,9 & 2 & 2,1 & 57 & 60,0 & 95 & 100,0 \\
$1816-1826$ & 85 & 51,8 & 7 & 4,3 & 72 & 43,9 & 164 & 100,0 \\
$1827-1837$ & 73 & 41,7 & 18 & 10,3 & 84 & 48,0 & 175 & 100,0 \\
$1838-1848$ & 48 & 62,3 & 9 & 11,7 & 20 & 26,0 & 77 & 100,0 \\
$1849-1859$ & 121 & 65,4 & 11 & 5,9 & 53 & 28,7 & 185 & 100,0 \\
$1860-1871$ & 17 & 53,1 & 2 & 6,3 & 13 & 40,6 & 32 & 100,0 \\
$1872-1888$ & 17 & 34,0 & 5 & 10,0 & 28 & 56,0 & 50 & 100,0 \\
$1805-1888$ & 397 & 51,0 & 54 & 7,0 & 327 & 42,0 & 778 & \\
\hline
\end{tabular}

FONTES: Livros de batismos de escravos da Ilha Grande de 1805-1847 e de 1850-1861; Livro de batismos de ingênuos da Ilha Grande, 1872-1888; Livro de batismos de escravos de Mambucaba, 1830-1871; Livro de batismos de escravos da Ribeira, 1824-1826; e Livro de batismos, casamentos e óbitos de escravos e de livres de Jacuecanga, 18001888. Convento do Carmo e Igreja de Jacuecanga, Angra dos Reis, RJ.

NOTA: Em um batismo o padrinho foi Santo Glorioso São Sebastião, seis padrinhos não foram citados e em nove cerimônias, a situação social dos padrinhos estavam ilegíveis.

Portanto, em Angra, os casais preferiram, relativamente, mais compadres escravos entre 1805 e 1872. Ou seja, mesmo diante de transformações econômicas e demográficas o perfil de compadrio manteve-se inalterado, melhor dizendo, houve um aumento da representatividade de escravos.

Buscar padrinhos escravos era, antes de tudo, selecionar indivíduos portadores de uma vivência e experiência calcada no cativeiro. Isto é, o papel de pais espirituais de crianças legítimas foi desempenhado, muitas vezes, por outros escravos. Da mesma forma que significava que os pais optaram por adotar laços de compadrio com outros cativos. Ou seja, este segmento tendeu a constituir ou reforçar laços de amizade, de trocas e de favores entre seus "iguais".

Estando num quadro de gradativa diminuição da quantidade de mão-de-obra, após 1850, de aumento percentual de crioulos e do perigo constante de venda de escravos; melhor dizendo diante de um momento de instabilidade, real ou sentida, a família legitimada pelo casamento continuou optando por cativos para o compadrio e o apadrinhamento. Por conseguinte, buscou-se companheiros de cativeiro a fim de efetuar laços, reforçando redes de amizade, de solidariedade e de parentesco.

Os homens livres também tiveram uma importante participação nos batismos de crianças legítimas, principalmente entre 1805-1849 e após 1872. A opção pela adoção do 
compadrio com livres resultou de famílias que, já dispondo de importantes redes de amizade no interior da comunidade escrava, desejaram estreitar seus contatos com os livres. Após 1872, a intensa diminuição de escravos intensificou os contatos entre escravos e livres.

\section{TABELA 62}

Situação social de padrinhos de crianças escravas e ingênuas ilegítimas por subperíodos. Angra dos Reis, 1805-1888

\begin{tabular}{l|lr|lr|rrr|rr}
\hline Subperíodos & \multicolumn{2}{|c|}{ Escravos } & \multicolumn{3}{c|}{ Forros } & \multicolumn{3}{c}{ Livres } & \multicolumn{3}{c}{ Total } \\
& $\mathrm{n}^{\text {o }}$ & $\%$ & $\mathrm{~N}^{\text {o }}$ & $\%$ & $\mathrm{n}^{\text {o }}$ & $\%$ & $\mathrm{n}^{\text {o }}$ & $\%$ \\
\hline $1805-1815$ & 48 & 29,3 & 5 & 3,0 & 111 & 67,7 & 164 & 100,0 \\
$1816-1826$ & 124 & 37,0 & 24 & 7,2 & 187 & 55,8 & 335 & 100,0 \\
$1827-1837$ & 109 & 30,2 & 18 & 5,0 & 234 & 64,8 & 361 & 100,0 \\
$1838-1848$ & 102 & 39,4 & 21 & 8,1 & 136 & 52,5 & 259 & 100,0 \\
$1849-1859$ & 421 & 45,3 & 35 & 3,8 & 473 & 50,9 & 929 & 100,0 \\
$1860-1871$ & 197 & 49,1 & 10 & 2,5 & 194 & 48,4 & 401 & 100,0 \\
$1872-1888$ & 89 & 26,7 & 8 & 2,4 & 236 & 70,9 & 333 & 100,0 \\
$1805-1888$ & 1.090 & 39,2 & 121 & 4,3 & 1.571 & 56,5 & 2.782 & 100,0 \\
\hline
\end{tabular}

FONTES: Livros de batismos de escravos da Ilha Grande de 1805-1847 e de 1850-1861; Livros de batismo de ingênuos da Ilha Grande, 1872-1888; Livro de batismos de escravos de Mambucaba, 1830-1871; Livros de batismos de escravos da Ribeira, 1824-1826; e Livro de batismos, casamentos e óbitos de escravos e de livres de Jacuecanga, 18001888. Convento do Carmo e Igreja de Jacuecanga, Angra dos Reis, RJ.

NOTA: Em 14 cerimônias os padrinhos não foram citados e em 19, estavam ilegíveis.

No caso dos batismos de crianças naturais, os homens livres foram maioria entre os padrinhos, estando presentes em 56,5\% das cerimônias realizadas entre 1805 e 1888. Os escravos, por sua vez, estiveram em $39,2 \%$ dos sacramentos e os forros, em 4,3\% dos batismos.

Observamos que os livres foram mais citados em todos os subperíodos. Nos anos de 1860-1871, houve praticamente um equilíbrio entre padrinhos livres e escravos.

Analisando os informes a partir da divisão entre a primeira e a segunda metade do século XIX, constatamos que, entre 1805-1848, os cativos foram representados em 34,2\% dos batismos, os forros estiveram em 6,1\% e os livres, em 59,7\%. Entre 1849-1888, os percentuais foram de, respectivamente, 42,5\%, 3,2\% e 54,3\%. Ou seja, também entre as famílias formadas por mães solteiras, os padrinhos cativos foram, ao longo do tempo, convidados a participar do compadrio com maior freqüência. Isto significa que o aumento na participação de escravos ocorreu, em parte, independentemente do grau de legitimidade das famílias. Não obstante, as mulheres solteiras continuaram preferindo os livres, pois representaram 54,3\% dos padrinhos, entre 1849-1888. 
Estando-se num momento de gradativo aumento do risco, ao menos imaginário, de separação pela venda, as famílias encabeçadas por mães solteiras respondiam buscando adotar vínculos de amizade e de trocas com indivíduos em situação social superior, buscando proteção e possível ajuda em momentos difíceis.

Sobre o medo da separação das famílias que rondavam os cativos, Castro (1997) conta-nos um processo-crime muito interessante. Tomamos, aqui, a liberdade de resumir o caso e as conclusões da autora ${ }^{162}$.

Trata-se de um crime cometido por Justina, cativa de um pequeno ou médio senhor de escravos da freguesia de São Sebastião, no município de Campos, no ano de 1878. Segundo narração de Castro (1997), baseando-se no processo, o proprietário Antônio Pais da Silva era solteiro e vivia com sua caseira, Bibiana, forra, e seus filhos.

No dia do crime, Justina teria retirado as três crianças do quarto onde dormiam, pela janela e afogado-as no tanque perto da casa. Posteriormente, voltou ao quarto e tentou se matar, cortando a garganta. Não conseguindo, saiu novamente em busca de ajuda para realizar seu intento. Não encontrando quem a ajudasse, fugiu e se escondeu no mato por oito dias, quando, finalmente foi localizada.

Castro (1997, p. 349) apresenta o andamento do processo:

"Consensual nos depoimentos de todos os moradores da casa, inclusive do senhor, é a referência à convicção de Justina de que, à semelhança do que acontecera com Ignácia, cuja filha adotara, seria vendida no sertão sem as suas crianças, apesar da lei de 1869 (que proibia a separação entre as crianças escravas e os pais). A viagem estava marcada para o dia seguinte e as três crianças não acompanhariam Antônio Pais, Justina e Miguel”.

Continua a autora,

"Fosse verdadeira ou não a alegação das testemunhas, o fato é que a versão parecia suficientemente plausível para explicar o comportamento de Justina. Apesar das condições costumeiras que emprestavam ao cativeiro na casa de Antônio Pais uma dimensão de intimidade hierárquica, a dimensão de mercadoria, recalculada pela conjuntura do tempo, trazia para o primeiro plano a violência intrínseca à sociedade escravista” (CASTRO, 1997, p. 350).

${ }^{162}$ Para uma melhor descrição do crime e das conclusões, ver Castro (1997, p. 345-350). 
Enfim, o caso citado demonstra que o perigo de separação das famílias era uma constante na segunda metade do século, mesmo diante da Lei de $1869^{163}$.

TABELA 63

Senhores de padrinhos escravos e de pais de crianças escravas e ingênuas legítimas batizadas por subperíodos. Angra dos Reis, 1805-1888

\begin{tabular}{l|lr|rrr|rr}
\hline Subperíodos & \multicolumn{2}{|c|}{$\begin{array}{c}\text { Senhores } \\
\text { Iguais }\end{array}$} & \multicolumn{3}{c|}{$\begin{array}{c}\text { Senhores } \\
\text { Diferentes }\end{array}$} & \multicolumn{3}{c}{ Total } \\
& $\mathrm{n}^{\mathrm{o}}$ & $\%$ & $\mathrm{n}^{\mathrm{o}}$ & $\%$ & $\mathrm{n}^{\mathrm{o}}$ & $\%$ \\
\hline $1805-1815$ & 18 & 50,0 & 18 & 50,0 & 36 & 100,0 \\
$1816-1826$ & 43 & 56,6 & 33 & 43,4 & 76 & 100,0 \\
$1827-1837$ & 44 & 62,9 & 26 & 37,1 & 70 & 100,0 \\
$1838-1848$ & 29 & 63,0 & 17 & 37,0 & 46 & 100,0 \\
$1849-1859$ & 89 & 74,2 & 31 & 25,8 & 120 & 100,0 \\
$1860-1871$ & 6 & 37,5 & 10 & 62,5 & 16 & 1000 \\
$1872-1888$ & 5 & 100,0 & 0 & & 5 & 100,0 \\
$1805-1888$ & 234 & 63,4 & 135 & 36,6 & 369 & 100,0 \\
\hline
\end{tabular}

FONTES: Livros de batismos de escravos da Ilha Grande de 1805-1847 e de 1850-1861; Livro de batismos de ingênuos da Ilha Grande, 1872-1888; Livro de batismos de escravos de Mambucaba, 1830-1871; Livro de batismos de escravos da Ribeira, 1824-1826; e Livro de batismos, casamentos e óbitos de escravos e de livres de Jacuecanga, 18001888. Convento do Carmo e Igreja de Jacuecanga, Angra dos Reis, RJ.

NOTA: Em 25 batismos os proprietários dos batizandos não foram citados e em três, seus nomes estavam ilegíveis.

Os senhores dos padrinhos escravos de crianças legítimas foram, predominantemente, iguais aos dos pais dos batizandos. Entre 1805-1888, pais e padrinhos pertencentes ao mesmo senhor estiveram em 63,4\% das cerimônias, enquanto em 36,6\% dos sacramentos, os proprietários foram diferentes.

De 1805-1859 houve aumento de padrinhos escravos pertencentes à mesma propriedade que seus afilhados. Processo, em geral (1827-1837 e 1860-1871), acompanhado pelo aumento percentual de padrinhos escravos. Ou seja, ao longo da segunda metade do século XIX, famílias legitimadas tenderam a optar por escravos, sendo que estes foram, quase sempre de propriedade igual, com exceção de 1860-1871. Isto é, houve a preferência pela criação de laços na propriedade. Entre 1872-1888, quando a maior parte dos padrinhos eram livres, os cativos que se tornaram protetores pertenciam à mesma propriedade que seus afilhados.

O que dissemos fica mais visível com a apresentação dos percentuais seguintes: na primeira metade do século (1805-1848), 58,8\% de afilhados e de padrinhos pertenciam ao mesmo senhor; enquanto 41,2\% viviam em escravarias diferentes. Entre 1849-1888,

${ }^{163}$ Vale lembrar que o processo-crime foi de 1878. 
foram, respectivamente, $70,9 \%$ e $29,1 \%$. Houve um aumento na participação de cativos de mesma propriedade; sendo acompanhado pela elevação da participação de cativos como escravos.

Em arremate, o aumento de protetores escravos foi representado pela elevação de compadres pertencentes à mesma propriedade. Quem sabe não seriam médias ou grandes propriedades, onde a oferta de escravos era maior? ${ }^{164}$

Quando as famílias legitimadas pelo casamento escolhiam compadres escravos, selecionaram cativos que viviam em suas propriedades. Buscavam reforçar a inserção de seus filhos e o fortalecimento dos laços de amizade e de solidariedade dentro dos limites das propriedades em que atuavam. Ao longo do tempo, à medida que o percentual de escravos como padrinhos aumentou, elevou-se a freqüência daqueles de mesmo senhor. Os pais entendiam que deveriam se associar a outros cativos, garantindo amizades e apoio no seio do grupo no qual participavam. No caso de estarem em propriedades de maior porte, mais fácil seria a seleção de padrinhos dentre os escravos de seus senhores.

TABELA 64

Senhores de padrinhos escravos e de mães de crianças escravas e ingênuas ilegítimas batizadas por subperíodos. Angra dos Reis, 1805-1888

\begin{tabular}{l|lr|rrr|rr}
\hline Subperíodos & \multicolumn{3}{c|}{$\begin{array}{c}\text { Senhores } \\
\text { Iguais }\end{array}$} & \multicolumn{3}{c|}{ Senhores } & \multicolumn{3}{c}{ Total } \\
& $\mathrm{N}^{\text {o }}$ & $\%$ & $\mathrm{n}^{\text {o }}$ & $\%$ & $\mathrm{n}^{\text {o }}$ & $\%$ \\
\hline $1805-1815$ & 20 & 43,5 & 26 & 56,5 & 46 & 100,0 \\
$1816-1826$ & 37 & 33,0 & 75 & 67,0 & 112 & 100,0 \\
$1827-1837$ & 52 & 49,5 & 53 & 50,5 & 105 & 100,0 \\
$1838-1848$ & 49 & 52,1 & 45 & 47,9 & 94 & 100,0 \\
$1849-1859$ & 205 & 50,0 & 205 & 50,0 & 410 & 100,0 \\
$1860-1871$ & 28 & 16,3 & 144 & 83,7 & 172 & 100,0 \\
$1872-1888$ & 9 & 90,0 & 1 & 10,0 & 10 & 100,0 \\
$1805-1888$ & 400 & 42,1 & 549 & 57,9 & 949 & 100,0 \\
\hline
\end{tabular}

FONTES: Livros de batismos de escravos da Ilha Grande de 1805-1847 e de 1850-1861; Livro de batismos de ingênuos da Ilha Grande, 1872-1888; Livro de batismos de escravos de Mambucaba, 1830-1871; Livro de batismos de escravos da Ribeira, 1824-1826; e Livro de batismos, casamentos e óbitos de escravos e de livres de Jacuecanga, 18001888. Convento do Carmo e Igreja de Jacuecanga, Angra dos Reis, RJ.

NOTA: Os proprietários de padrinhos não foram citados em 125 batismos e em 16, seus nomes estavam ilegíveis.

No batismo de crianças naturais, as mães buscaram, relativamente, compadres pertencentes a outras propriedades. Isso ocorreu em 57,9\% dos sacramentos realizados

\footnotetext{
${ }^{164}$ Na freguesia de Inhaúma, no Rio de Janeiro, Góes (1993) verificou que os cativos pertencentes às maiores propriedades buscaram mais padrinhos e madrinhas entre os cativos de seus próprios senhores.
} 
entre 1805-1888. Padrinhos e afilhados naturais de iguais propriedades foram vistos em $42,1 \%$ das cerimônias ${ }^{165}$. Os padrinhos de diferentes propriedades foram majoritários na maior parte dos subperíodos, chegando a 83,7\%, entre 1860-1871.

As mães solteiras, freqüentemente, convidavam livres, ou seja, indivíduos fora do universo escravo. Quando escravos, eram de propriedades diferentes, também alargando os laços, além da escravaria em que viviam.

No batismo de naturais de Angra dos Reis, a seleção de padrinhos pressupunha o convite a escravos pertencentes a outras propriedades, até 1871. Talvez não possuíssem oferta suficiente de possíveis padrinhos nas propriedades em que viviam, propriedades de menor porte, onde os escravos existentes já estavam inseridos em laços de amizade e de parentesco. Conseqüentemente, as famílias estabeleciam laços para além dos limites das propriedades. Vale lembrar que as mães solteiras optavam por padrinhos livres, exatamente na busca por abertura dos contatos; quando convidavam escravos, selecionavam membros de outras escravarias. Ambos processos tinham um ponto em comum, a decisão consciente em abrir os vínculos para além das propriedades em que habitavam, independentemente se assumiam compadrio com livres ou com escravos. Embora pudesse resultar da dificuldade de localizar possíveis compadres nos limites dos plantéis.

Na comparação entre a primeira e a segunda metade do século XIX, elevou-se o percentual de padrinhos escravos. O aumento deste esteve relacionada à maior representatividade de escravos de diferentes propriedades. Entre 1805-1848, padrinhos e afilhados pertencentes ao mesmo senhor representou 44,3\% das cerimônias, enquanto entre 1849-1888, reduziu-se a 40,8\%. No caso de compadres de diferentes senhores, encontramos, respectivamente, $55,7 \%$ e 59,1\%. Muitos padrinhos escravos viviam na propriedade dos seus afilhados. A proximidade entre ambos garantia a fixação e fortalecimento de laços de apadrinhamento e de proteção.

A seguir, analisamos a variável origem, buscando compreender de que forma influenciava na escolha de padrinhos. Contabilizou-se os casais e compadres que tiveram suas origens localizadas.

${ }^{165}$ Comportamento diferente do encontrado para as crianças legítimas. 
TABELA 65

Origens dos pais de crianças escravas e ingênuas legítimas e dos padrinhos por subperíodos.

Angra dos Reis, 1805-1888

\begin{tabular}{c|c|c|c|c|c|c|c|c}
\hline ExMxP & $\begin{array}{c}1805-1815 \\
\mathrm{n}^{\circ}(\%)\end{array}$ & $\begin{array}{c}1816-1826 \\
\mathrm{n}^{\circ}(\%)\end{array}$ & $\begin{array}{c}1827-1837 \\
\mathrm{n}^{\circ}(\%)\end{array}$ & $\begin{array}{c}1838-1848 \\
\mathrm{n}^{\circ}(\%)\end{array}$ & $\begin{array}{c}1849-1859 \\
\mathrm{n}^{\circ}(\%)\end{array}$ & $\begin{array}{c}1860-1871 \\
\mathrm{n}^{\circ}(\%)\end{array}$ & $\begin{array}{c}1872-1888 \\
\mathrm{n}^{\circ}(\%)\end{array}$ & $\begin{array}{c}1805-1888 \\
\mathrm{n}^{\circ}(\%)\end{array}$ \\
\hline AxAxA & $2(50,0)$ & $20(52,6)$ & $25(51,0)$ & $17(43,6)$ & $27(37,5)$ & $1(14,3)$ & 0 & $92(42,6)$ \\
CxCxC & 0 & 0 & $2(4,1)$ & 0 & $2(2,8)$ & $4(57,1)$ & $5(71,4)$ & $13(6,0)$ \\
Endogamia & $2(50,0)$ & $20(52,6)$ & $27(55,1)$ & $17(43,6)$ & $29(40,3)$ & $5(71,4)$ & $5(71,4)$ & $105(48,6)$ \\
AxAxC & 0 & $8(21,0)$ & $10(20,4)$ & $12(30,8)$ & $11(15,3)$ & $1(14,3)$ & 0 & $42(19,4)$ \\
AxCxA & $1(25,0)$ & $2(5,3)$ & $3(6,1)$ & $2(5,1)$ & $1(1,4)$ & 0 & 0 & $9(4,2)$ \\
AxCxC & 0 & $1(2,6)$ & $4(8,2)$ & $2(5,1)$ & $5(6,9)$ & 0 & 0 & $12(5,5)$ \\
CxAxA & $1(25,0)$ & $4(10,5)$ & $2(4,1)$ & $2(5,1)$ & $17(23,6)$ & 0 & $1(14,3)$ & $27(12,5)$ \\
CxAxC & 0 & $3(7,9)$ & $3(6,1)$ & $4(10,2)$ & $9(12,5)$ & $1(14,3)$ & $1(14,3)$ & $21(9,7)$ \\
Exogamia & $2(50,0)$ & $18(47,4)$ & $22(44,9)$ & $22(56,4)$ & $43(59,7)$ & $2(28,6)$ & $2(28,6)$ & $111(51,4)$ \\
Total & $4(100,0)$ & $38(100,0)$ & $49(100,0)$ & $39(100,0)$ & $72(100,0)$ & $7(100,0)$ & $7(100,0)$ & $216(100,0)$ \\
\hline
\end{tabular}

FONTES: Livros de batismos de escravos da Ilha Grande de 1805-1847 e de 1850-1861; Livro de batismos de ingênuos da Ilha Grande, 1872-1888; Livro de batismos de escravos de Mambucaba, 1830-1871; Livro de batismos de escravos da Ribeira, 1824-1826; e Livro de batismos, casamentos e óbitos de escravos e de livres de Jacuecanga, 18001888. Convento do Carmo e Igreja de Jacuecanga, Angra dos Reis, RJ.

NOTAS: E=Esposa; M=Marido; P=Padrinho. Em 562 cerimônias não foi possível localizar a origem de um dos envolvidos, mães, pais ou padrinhos.

Quanto a escolha de padrinhos a partir da variável origem, houve um ligeiro predomínio da exogamia, correspondendo a 51,4\% dos batismos. Entretanto, padrinhos e pais de igual origem corresponderam a 48,6\% das cerimônias. Portanto, quando os pais escolheram seus compadres, não se preocuparam com a origens daqueles.

Não obstante, mais importante que a origem, parece ter sido a escolha dos compadres a partir da situação social. Como sabemos, famílias legitimadas convidavam, geralmente, escravos. 
TABELA 66

Origens das mães de crianças escravas e ingênuas ilegítimas e dos padrinhos por subperíodos.

Angra dos Reis, 1805-1888

\begin{tabular}{c|c|c|c|c|c|c|c|c}
\hline MxP & $\begin{array}{c}1805-1815 \\
\mathrm{n}^{\circ}(\%)\end{array}$ & $\begin{array}{c}1816-1826 \\
\mathrm{n}^{\circ}(\%)\end{array}$ & $\begin{array}{c}1827-1837 \\
\mathrm{n}^{\circ}(\%)\end{array}$ & $\begin{array}{c}1838-1848 \\
\mathrm{n}^{\circ}(\%)\end{array}$ & $\begin{array}{c}1849-1859 \\
\mathrm{n}^{\circ}(\%)\end{array}$ & $\begin{array}{c}1860-1871 \\
\mathrm{n}^{\circ}(\%)\end{array}$ & $\begin{array}{c}1872-1888 \\
\mathrm{n}^{\circ}(\%)\end{array}$ & $\begin{array}{c}1805-1888 \\
\mathrm{n}^{\circ}(\%)\end{array}$ \\
\hline AxA & $3(60,0)$ & $26(39,4)$ & $35(51,5)$ & $30(44,1)$ & $84(36,1)$ & $10(8,8)$ & 0 & $188(33,0)$ \\
CxC & 0 & $12(18,2)$ & $5(7,3)$ & $4(5,9)$ & $54(23,2)$ & $59(52,2)$ & $15(88,2)$ & $149(26,1)$ \\
Endogamia & $3(60,0)$ & $38(57,6)$ & $40(58,8)$ & $34(50,0)$ & $138(59,2)$ & $69(61,1)$ & $15(88,2)$ & $337(59,1)$ \\
AxC & $1(20,0)$ & $25(37,9)$ & $18(26,5)$ & $19(27,9)$ & $45(19,3)$ & $10(8,8)$ & 0 & $118(20,7)$ \\
CxA & $1(20,0)$ & $3(4,5)$ & $10(14,7)$ & $15(22,1)$ & $50(21,4)$ & $34(30,1)$ & $2(11,8)$ & $115(20,2)$ \\
Exogamia & $2(40,0)$ & $28(42,4)$ & $28(41,2)$ & $34(50,0)$ & $95(40,8)$ & $44(38,9)$ & $2(11,8)$ & $233(40,9)$ \\
Total & $5(100,0)$ & $66(100,0)$ & $68(100,0)$ & $68(100,0)$ & $233(100,0)$ & $113(100,0)$ & $17(100,0)$ & $570(100,0)$ \\
\hline
\end{tabular}

FONTES: Livros de batismos de escravos da Ilha Grande de 1805-1847 e de 1850-1861; Livro de batismos de ingênuos da Ilha Grande, 1872-1888; Livro de batismos de escravos de Mambucaba, 1830-1871; Livro de batismos de escravos da Ribeira, 1824-1826; e Livro de batismos, casamentos e óbitos de escravos e de livres de Jacuecanga, 18001888. Convento do Carmo e Igreja de Jacuecanga, Angra dos Reis, RJ.

NOTAS: M=Mãe; P=Padrinho. Em 2.212 cerimônias não existiam informações sobre a origens de mães ou de padrinhos.

Entre as mães solteiras, houve uma tendência à endogamia, chegando a 59,1\% das cerimônias.

Ao longo do tempo, caminhou-se rumo à “crioulização”, promovendo a elevação da representatividade dos laços entre cativos nascidos no Brasil. Por isso, a endogamia no compadrio, no caso das famílias formadas por mães solteiras caracterizou-se, gradativamente, por ser crioula.

A endogamia foi vista também na freguesia de São José, no Rio de Janeiro, entre 1802-1822, onde mães e padrinhos crioulos corresponderam a 74,8\%, e mães e padrinhos africanos, 56,1\% (FERREIRA, 2000, p. 203). 
TABELA 67

Situação social de madrinhas de crianças escravas e ingênuas legítimas por subperíodos.

Angra dos Reis, 1805-1888

\begin{tabular}{l|lr|lr|rrr|rr}
\hline Subperíodos & \multicolumn{2}{|c|}{ Escravas } & \multicolumn{3}{c|}{ Forras } & \multicolumn{3}{c}{ Livres } & \multicolumn{3}{c}{ Total } \\
& $\mathrm{n}^{\text {o }}$ & $\%$ & $\mathrm{n}^{\text {o }}$ & $\%$ & $\mathrm{n}^{\text {o }}$ & $\%$ & $\mathrm{n}^{\text {o }}$ & 100,0 \\
\hline $1805-1815$ & 34 & 39,1 & 3 & 3,4 & 50 & 57,5 & 87 & 100,0 \\
$1816-1826$ & 81 & 55,8 & 9 & 6,3 & 55 & 37,9 & 145 & 100,0 \\
$1827-1837$ & 64 & 45,7 & 17 & 12,2 & 59 & 42,1 & 140 & 100,0 \\
$1838-1848$ & 42 & 71,2 & 4 & 6,8 & 13 & 22,0 & 59 & 100,0 \\
$1849-1859$ & 109 & 76,8 & 8 & 5,6 & 25 & 17,6 & 142 & 100,0 \\
$1860-1871$ & 19 & 95,0 & 1 & 5,0 & 0 & & 20 & 100,0 \\
$1872-1888$ & 12 & 52,2 & 1 & 4,3 & 10 & 43,5 & 23 & 100,0 \\
$1805-1888$ & 361 & 58,6 & 43 & 7,0 & 212 & 34,4 & 616 & \\
\hline
\end{tabular}

FONTES: Livros de batismos de escravos da Ilha Grande de 1805-1847 e de 1850-1861; Livro de batismos de ingênuos da Ilha Grande, 1872-1888; Livro de batismos de escravos de Mambucaba, 1830-1871; Livro de batismos de escravos da Ribeira, 1824-1826; e Livro de batismos, casamentos e óbitos de escravos e de livres de Jacuecanga, 18001888. Convento do Carmo e Igreja de Jacuecanga, Angra dos Reis, RJ.

NOTA: Em 146 cerimônias, as madrinhas foram santas, em 22 batismos as madrinhas não foram citadas e em 10, suas situações sociais estavam ilegíveis.

As crianças legítimas receberam madrinhas escravas em 58,6\% dos sacramentos. As livres foram citadas em 34,4\% dos batismos; e as forras, em 7,0\%.

Nos subperíodos, com exceção de 1805-1815 (predomínio de livres), as madrinhas escravas foram mais freqüentes. Em geral, excluindo o subperíodo de 18271837, houve um aumento percentual das escravas, até 1871. De 1872-1888, diminuiu.

Observando os dados para a primeira e a segunda metade dos oitocentos, encontramos: 51,3\% de escravas na qualidade de madrinhas, 7,6\% de forras e 41,1\% de livres. Entre 1849-1888 chegamos a, respectivamente, 75,7\%, 5,4\% e 18,9\%.

Houve, portanto, um aumento de cativas como comadres.

Assim como entre os padrinhos, os casais escravos que viviam em Angra escolheram madrinhas escravas, mulheres conhecedoras da realidade destinada ao afilhado. Além disso, a opção por escravas aumentou até 1871, demonstrando o reforço do compadrio com outros escravos, fortalecendo amizades em meio a uma comunidade escrava cada vez mais marcada por cativos de origem nacional. 
TABELA 68

Representações religiosas presentes nos batismos de crianças escravas e ingênuas legítimas por subperíodos. Angra dos Reis, 1805-1888

\begin{tabular}{|c|c|c|c|c|c|c|c|c|c|c|c|c|}
\hline \multirow[t]{2}{*}{ Subperíodos } & \multicolumn{2}{|c|}{ AS } & \multicolumn{2}{|c|}{ NS } & \multicolumn{2}{|c|}{ SC } & \multicolumn{2}{|c|}{ SR } & \multicolumn{2}{|c|}{$\mathrm{BD}$} & \multicolumn{2}{|c|}{ Total } \\
\hline & $\mathrm{n}^{\mathrm{o}}$ & $\%$ & $\mathrm{n}^{\mathrm{o}}$ & $\%$ & $\mathrm{n}^{\mathrm{o}}$ & $\%$ & $\mathrm{n}^{\mathrm{o}}$ & $\%$ & $n^{\circ}$ & $\%$ & $\mathrm{n}^{\mathrm{o}}$ & $\%$ \\
\hline $1805-1815$ & 3 & 100,0 & 0 & & 0 & & 0 & & 0 & & 3 & 100,0 \\
\hline 1816-1826 & 11 & 64,7 & 1 & 5,9 & 4 & 23,5 & 0 & & 1 & 5,9 & 17 & 100,0 \\
\hline 1827-1837 & 10 & 38,5 & 13 & 50,0 & 0 & & 3 & 11,5 & 0 & & 26 & 100,0 \\
\hline 1838-1848 & 0 & & 5 & 26,3 & 0 & & 14 & 73,7 & 0 & & 19 & 100,0 \\
\hline 1849-1859 & 8 & 19,0 & 34 & 81,0 & 0 & & 0 & & 0 & & 42 & 100,0 \\
\hline 1860-1871 & 0 & & 11 & 91,7 & 0 & & 1 & 8,3 & 0 & & 12 & 100,0 \\
\hline 1872-1888 & 0 & & 27 & 100,0 & 0 & & 0 & & 0 & & 27 & 100,0 \\
\hline 1805-1888 & 32 & 21,9 & 91 & 62,3 & 4 & 2,7 & 18 & 12,3 & 1 & 0,8 & 146 & 100,0 \\
\hline
\end{tabular}

FONTES: Livros de batismos de escravos da Ilha Grande de 1805-1847 e de 1850-1861; Livro de batismos de ingênuos da Ilha Grande, 1872-1888; Livro de batismos de escravos de Mambucaba, 1830-1871; Livro de batismos de escravos da Ribeira, 1824-1826; e Livro de batismos, casamentos e óbitos de escravos e de livres de Jacuecanga, 18001888. Convento do Carmo e Igreja de Jacuecanga, Angra dos Reis, RJ.

NOTA: SA=Santa Ana; NS=Nossa Senhora; SC=Senhora da Conceição; SR=Senhora do Rosário; BD=Senhora do Bom Despacho.

Dentre as santas, Nossa Senhora foi indicada em 62,3\% das cerimônias; Santa Ana foi anotada em 21,9\%; Nossa Senhora do Rosário, em 12,3\%; Nossa Senhora da Conceição, em 2,7\%; e Nossa Senhora do Bom Despacho, em 0,8\%.

Entre os anos de 1805 e 1849, Santa Ana foi citada em cerimônias da Ilha Grande, freguesia que recebia o nome daquela santa; Nossa Senhora foi anotada em 30,3\% dos batismos, indicada em registros de todas as freguesias; Nossa Senhora do Rosário foi protetora em 25,7\% das cerimônias, todas realizadas em Mambucaba, freguesia que pegava-lhe de empréstimo o nome; Nossa Senhora da Conceição, em 6,1\% dos batismos, todos realizados na freguesia de Nossa Senhora da Conceição da Ribeira. Nossa Senhora do Bom Despacho foi citada em 1,5\% das cerimônias. Portanto, nesses anos houve relativa correspondência entre as santas e aquelas evocadas nas respectivas freguesias.

Entre 1850-1871, excluindo os oito batismos da Ilha Grande, nos quais Santa Ana foi lembrada e um, realizado em Mambucaba, que anotou Nossa Senhora do Rosário como protetora, nos demais sacramentos, Nossa Senhora foi a mais indicada como protetora espiritual. Esta foi, entre 1872 e 1888, a única anotada nos sacramentos.

Assim como ocorreu entre os adultos, a pouca variedade de santas nos levam a crer que a indicação resultou, tanto entre as crianças legítimas quanto ilegítimas, de uma 
formalidade, ou seja, da necessidade de se preencher, ao lado da palavra madrinha, alguma protetora.

\section{TABELA 69}

Situação social de madrinhas de crianças escravas e ingênuas ilegítimas por subperíodos.

Angra dos Reis, 1805-1888

\begin{tabular}{|c|c|c|c|c|c|c|c|c|}
\hline \multirow[t]{2}{*}{ Subperíodos } & \multicolumn{2}{|c|}{ Escravas } & \multicolumn{2}{|c|}{ Forras } & \multicolumn{2}{|c|}{ Livres } & \multicolumn{2}{|c|}{ Total } \\
\hline & $\mathrm{n}^{\mathrm{o}}$ & $\%$ & $\mathrm{n}^{0}$ & $\%$ & $\mathrm{n}^{\mathrm{o}}$ & $\%$ & $\mathrm{n}^{\mathrm{o}}$ & $\%$ \\
\hline $1805-1815$ & 51 & 33,3 & 6 & 3,9 & 96 & 62,8 & 153 & 100,0 \\
\hline 1816-1826 & 123 & 41,8 & 33 & 11,2 & 138 & 47,0 & 294 & 100,0 \\
\hline 1827-1837 & 98 & 35,8 & 12 & 4,4 & 164 & 59,8 & 274 & 100,0 \\
\hline 1838-1848 & 101 & 57,1 & 7 & 3,9 & 69 & 39,0 & 177 & 100,0 \\
\hline 1849-1859 & 372 & 62,3 & 23 & 3,8 & 202 & 33,9 & 597 & 100,0 \\
\hline $1860-1871$ & 135 & 65,2 & 11 & 5,3 & 61 & 29,5 & 207 & 100,0 \\
\hline 1872-1888 & 41 & 34,8 & 9 & 7,6 & 68 & 57,6 & 118 & 100,0 \\
\hline 1805-1888 & 921 & 50,6 & 101 & 5,6 & 798 & 43,8 & 1820 & 100,0 \\
\hline
\end{tabular}

FONTES: Livros de batismos de escravos da Ilha Grande de 1805-1847 e de 1850-1861; Livro de batismos de ingênuos da Ilha Grande, 1872-1888; Livro de batismos de escravos de Mambucaba, 1830-1871; Livro de batismos de escravos da Ribeira, 1824-1826; e Livro de batismos, casamentos e óbitos de escravos e de livres de Jacuecanga, 18001888. Convento do Carmo e Igreja de Jacuecanga, Angra dos Reis, RJ.

NOTA: Em 923 batismos, as madrinhas foram santas, em 51 as madrinhas não foram citadas e em 21 suas situações sociais estavam ilegíveis.

As mães solteiras optaram por comadres escravas em 50,6\% das cerimônias realizadas entre os anos de 1805 a 1888; por forras, em 5,6\%; e, por livres, em 43,8\%. Entre 1805-1837, predominaram as mulheres livres; entre 1838-1871, as cativas; e nos anos de 1872-1888, destacaram-se, mais uma vez, as madrinhas livres.

Somando os dados de 1805 até 1848, o percentual de escravas correspondeu a 41,5\%; as forras foram representadas em 6,4\% dos sacramentos; e as livres, em 52,0\%. De 1849 a 1888, os percentuais foram de, respectivamente, 59,4\%, 4,7\% e 35,9\%. Eles apontam para a preferência, assim como entre as famílias legítimas, por madrinhas escravas, com a chegada da segunda metade dos oitocentos. Logo, concluímos que, durante o acirramento da crise econômica e num momento demográfico desvantajoso, mães solteiras e pais passaram a se interessar pela formação de laços com mulheres conhecedoras da realidade do cativeiro.

De qualquer forma, famílias ilegítimas tinham uma tendência a se aproximar mais dos livres. Os informes relativos ao batismo de inocentes ilegítimos, caracterizados pelo predomínio de padrinhos livres, em quase todos os subperíodos, e de madrinhas livres, entre 1805-1837 e 1872-1888, foram encontrados, também, em Campos, Capitania do Rio de Janeiro, nos séculos XVII e XVIII. 
Na freguesia de São Gonçalo, em Campos, nos anos entre 1770 e 1786, as crianças legítimas foram apadrinhadas por escravos em 63,3\% das cerimônias; enquanto, as ilegítimas receberam, em 50,5\% dos sacramentos, padrinhos e madrinhas livres/libertos (FARIA, 1998, p. 321).

No caso da dita freguesia, a autora estudou os batismos dos anos de 1645-1668. Nestes existiram mães solteiras que indicaram os nomes dos pais das crianças, e mulheres que omitiram aqueles nomes. Entre estas últimas, Faria (1998) encontrou maior freqüência de padrinhos e madrinhas livres/libertos (FARIA, 1998, p. 320). Entre eles havia indivíduos que possuíam designações como "sargento-mor”, “alferes”, “capitão”, e, no caso das madrinhas, indicações como “dona”. Em outras palavras, as mães solteiras que não indicaram os nomes dos pais de seus filhos, tiveram maior percentual de padrinhos e madrinhas em situação social superior, e, dentre estes, pessoas consideradas de destaque e influência na região. Baseando-se nestes dados, a autora levantou a hipótese de que os filhos destas mulheres poderiam ser a prole bastarda dos senhores casados ou de seus filhos e parentes. Exatamente por isso as mães não poderiam citar o nome dos pais de seus filhos e, como resultado, os parentes dos pais das crianças acabavam constituindo-se como padrinhos dos menores (FARIA, 1998, p. 320).

Infelizmente, não há mulheres solteiras que citaram os nomes dos pais de seus filhos, mas encontramos senhores e senhoras de outros escravos e indivíduos designados como “capitães”, “tenentes”, “alferes” e “donas”, na qualidade de padrinhos e madrinhas. E estes, quando apareciam, apadrinharam crianças ilegítimas, presentes, no caso dos padrinhos, em 228 sacramentos, contra 58 batismos de inocentes legítimos, e, entre as madrinhas, em 29 e 11 cerimônias, respectivamente.

Não sabemos se tais pessoas apadrinharam parentes, entretanto a freqüência de padrinhos e madrinhas com aquelas características, em cerimônias de crianças ilegítimas, indicava a tentativa de tais mães solteiras em fazer do ritual batismal um momento de estabelecimento de alianças com pessoas não apenas com alguma influência na localidade, mas capazes de ajudá-las.

Comparando as tabelas relativas às madrinhas de legítimos e de ilegítimos observamos que, em ambas, o movimento relativo à freqüência de escravas na qualidade de protetoras espirituais foi semelhante. Entre 1805 e 1815 e de 1816 a 1826, aumentou 
os percentuais de madrinhas escravas; entre 1816 e 1826 e de 1827 a 1837, diminuiu; entre 1827 e 1837 até 1860-1871, a presença de escravas voltou a aumentar; de 18601871 e 1872-1888, novamente diminuiu.

TABELA 70

Representações religiosas presentes nos batismos de crianças escravas e ingênuas ilegítimas por subperíodos. Angra dos Reis, 1805-1888

\begin{tabular}{|c|c|c|c|c|c|c|c|c|c|c|c|c|c|c|c|c|}
\hline \multirow[t]{2}{*}{ Subperíodos } & \multicolumn{2}{|c|}{ AS } & \multicolumn{2}{|c|}{ NS } & \multicolumn{2}{|c|}{ SC } & \multicolumn{2}{|c|}{ SR } & \multicolumn{2}{|c|}{ SB } & \multicolumn{2}{|c|}{ SD } & \multicolumn{2}{|c|}{ SP } & \multicolumn{2}{|c|}{ Total } \\
\hline & $\mathrm{n}^{\mathrm{o}}$ & $\%$ & $n^{\circ}$ & $\%$ & $\mathrm{n}^{\mathrm{o}}$ & $\%$ & $\mathrm{n}^{\circ}$ & $\%$ & $n^{\circ}$ & $\%$ & $n^{\circ}$ & $\%$ & $n^{\circ}$ & $\%$ & $n^{0}$ & $\%$ \\
\hline $1805-1815$ & 6 & 100,0 & 0 & & 0 & & 0 & & 0 & & 0 & & 0 & & 6 & 100,0 \\
\hline 1816-1826 & 21 & 63,6 & 1 & 3,0 & 11 & 33,3 & 0 & & 0 & & 0 & & 0 & & 33 & 100,0 \\
\hline 1827-1837 & 35 & 52,2 & 18 & 26,9 & 1 & 1,5 & 13 & 19,4 & 0 & & 0 & & 0 & & 67 & 100,0 \\
\hline $1838-1848$ & 0 & & 42 & 51,2 & 0 & & 40 & 48,8 & 0 & & 0 & & 0 & & 82 & 100,0 \\
\hline 1849-1859 & 57 & 17,7 & 255 & 78,9 & 2 & 0,6 & 7 & 2,2 & 1 & 0,3 & 1 & 0,3 & 0 & & 323 & 100,0 \\
\hline 1860-1871 & 1 & 0,5 & 172 & 89,1 & 4 & 2,1 & 11 & 5,7 & 0 & & 4 & 2,1 & 1 & 0,5 & 193 & 100,0 \\
\hline 1872-1888 & 2 & 0,9 & 212 & 96,8 & 0 & & 0 & & 1 & 0,5 & 4 & 1,8 & 0 & & 219 & 100,0 \\
\hline 1805-1888 & 122 & 13,2 & 700 & 75,8 & 18 & 1,9 & 71 & 7,7 & 2 & 0,2 & 9 & 1,0 & 1 & 0,2 & 923 & 100,0 \\
\hline
\end{tabular}

FONTES: Livros de batismos de escravos da Ilha Grande de 1805-1847 e de 1850-1861; Livro de batismos de ingênuos da Ilha Grande, 1872-1888; Livro de batismos de escravos de Mambucaba, 1830-1871; Livro de batismos de escravos da Ribeira, 1824-1826; e Livro de batismos, casamentos e óbitos de escravos e de livres de Jacuecanga, 18001888. Convento do Carmo e Igreja de Jacuecanga, Angra dos Reis, RJ.

NOTA: SA=Santa Ana; NS=Nossa Senhora; SC=Senhora da Conceição; SR=Senhora do Rosário; SB=Senhora de Belém; SD=Senhora das Dores; $\mathrm{SP}=$ Senhora do Parto.

Entre 1805-1888, Nossa Senhora foi citada em 75,8\% das cerimônias. Santa Ana foi indicada em 13,2\% dos batismos, todos realizados na Ilha Grande; Nossa Senhora do Rosário esteve em 7,7\% dos sacramentos, todos de Mambucaba; Nossa Senhora da Conceição foi anotada em 1,9\% das cerimônias, sendo que 10 batismos foram realizados na Ribeira. Portanto, assim como nos batismos de legítimos, houve uma correlação entre as representações religiosas e as protetoras das respectivas freguesias. 
TABELA 71

Senhores de madrinhas escravas e de pais crianças escravas e ingênuas legítimas batizadas por subperíodos. Angra dos Reis, 1805-1888

\begin{tabular}{c|lr|rrr|rr}
\hline Subperíodos & \multicolumn{2}{|c|}{$\begin{array}{c}\text { Senhores } \\
\text { Iguais }\end{array}$} & \multicolumn{3}{c|}{$\begin{array}{c}\text { Senhores } \\
\text { Diferentes }\end{array}$} & \multicolumn{3}{c}{ Total } \\
& $\mathrm{n}^{\text {o }}$ & $\%$ & $\mathrm{n}^{\text {o }}$ & $\%$ & $\mathrm{n}^{\mathrm{o}}$ & 100,0 \\
\hline $1805-1815$ & 18 & 54,5 & 15 & 45,5 & 33 & 100,0 \\
$1816-1826$ & 41 & 56,2 & 32 & 43,8 & 73 & 100,0 \\
$1827-1837$ & 46 & 76,7 & 14 & 23,3 & 60 & 100,0 \\
$1838-1848$ & 25 & 61,0 & 16 & 39,0 & 41 & 100,0 \\
$1849-1859$ & 72 & 66,1 & 37 & 33,9 & 109 & 100,0 \\
$1860-1871$ & 9 & 52,9 & 8 & 47,1 & 17 & 100,0 \\
$1872-1888$ & 4 & 100,0 & 0 & & 4 & 100,0 \\
$1805-1888$ & 215 & 63,8 & 122 & 36,2 & 337 & \\
\hline
\end{tabular}

FONTES: Livros de batismos de escravos da Ilha Grande de 1805-1847 e de 1850-1861; Livro de batismos de ingênuos da Ilha Grande, 1872-1888; Livro de batismos de escravos de Mambucaba, 1830-1871; Livro de batismos de escravos da Ribeira, 1824-1826; e Livro de batismos, casamentos e óbitos de escravos e de livres de Jacuecanga, 18001888. Convento do Carmo e Igreja de Jacuecanga, Angra dos Reis, RJ.

NOTA: Em 21 cerimônias, os proprietários não foram citados e em três, seus nomes estavam ilegíveis.

As madrinhas escravas foram comuns entre os batismos de legítimos, como já foi dito. Estas mulheres, geralmente, pertenciam à mesma propriedade que os pais de seus afilhados, em 63,8\% dos sacramentos. Já comadres e casais de diferentes senhores estiveram em 36,2\%. Em todos os subperíodos predominaram madrinhas e afilhados de igual propriedade.

Góes (1993, p. 79), comparando a condição jurídica dos padrinhos e madrinhas a partir da faixa de tamanho relativa das propriedades ${ }^{166}$, observou que em Inhaúma, entre 1817-1842, à medida que crescia o número de escravos por propriedades, tendia, gradativamente, a aumentar a presença de padrinhos e madrinhas de igual dono.

Pegando de empréstimo a constatação do autor, podemos especular que os pais que faziam do batismo o momento para o estabelecimento e reforço de vínculos com escravas que viviam na mesma propriedade, poderiam estar inseridos em escravarias de médio a grande porte, possibilitando a seleção de comadres entre as escravas pertencentes aos seus senhores. Seus filhos tinham entre os escravos de seus proprietários, no caso das

\footnotetext{
${ }^{166}$ Tratou-se do tamanho relativo, pois o autor realizou uma estimativa dos números de escravos por propriedades, baseando-se nos números de adultos que compareceram às cerimônias de batismo, na qualidade de batizandos, pais, padrinhos e madrinhas. Portanto, Góes teve acesso ao número mínimo de escravos que pertenciam aos senhores.
} 
crianças escravas, e de seus pais, no caso das ingênuas, protetoras que poderiam socorrer e apoiar seus afilhados em situações inesperadas, como a separação de pais e filhos.

Unindo os informes entre 1805-1848 e de 1849-1888, constatamos que comadres pertencentes ao mesmo senhor representaram $62,8 \%$ e $65,4 \%$, respectivamente; enquanto que comadres de diferentes escravarias corresponderam a $37,2 \%$ e $34,6 \%$.

Por conseguinte, o aumento do percentual de comadres escravas representou maior freqüência de convites feitos às escravas que conviviam na mesma propriedade de seus futuros afilhados.

Finalmente, observamos que os pais de crianças legítimas tinham definido um comportamento específico no momento do batismo, pressupondo, a seleção de padrinhos e madrinhas escravos que, predominantemente, pertenciam ao mesmo senhor. Os laços de compadrio constituíram vínculos entre escravos, reforçando amizades e solidariedades e os de apadrinhamento inseriram as crianças na comunidade.

Com a conformação de um contexto de diminuição do número de escravos, de aumento percentual de crioulos e de risco de venda de cativos no tráfico interno, as famílias legitimadas convidavam, mais e mais, cativos que viviam em suas propriedades a fim de criar laços de compadrio. Tratava-se de buscar o reconhecimento e apoio dentre os participantes de sua realidade de vida, por solidariedade e ajuda na criação de seus filhos.

No caso das crianças ilegítimas, o movimento foi diferente. 
TABELA 72

Senhores de madrinhas escravas e de mães de crianças escravas e ingênuas ilegítimas batizadas por subperíodos. Angra dos Reis, 1805-1888

\begin{tabular}{l|lr|rrr|rr}
\hline Subperíodos & \multicolumn{3}{|c|}{$\begin{array}{c}\text { Senhores } \\
\text { Iguais }\end{array}$} & \multicolumn{3}{c|}{$\begin{array}{c}\text { Senhores } \\
\text { Diferentes }\end{array}$} & \multicolumn{3}{c}{ Total } \\
& $\mathrm{n}^{\mathrm{o}}$ & $\%$ & $\mathrm{n}^{\mathrm{o}}$ & $\%$ & $\mathrm{n}^{\mathrm{o}}$ & 100,0 \\
\hline $1805-1815$ & 21 & 42,0 & 29 & 58,0 & 50 & 100,0 \\
$1816-1826$ & 38 & 33,9 & 74 & 66,1 & 112 & 100,0 \\
$1827-1837$ & 44 & 45,9 & 52 & 54,1 & 96 & 100,0 \\
$1838-1848$ & 42 & 47,2 & 47 & 52,8 & 89 & 100,0 \\
$1849-1859$ & 169 & 46,7 & 193 & 53,3 & 362 & 100,0 \\
$1860-1871$ & 15 & 13,2 & 99 & 86,8 & 114 & 100,0 \\
$1872-1888$ & 6 & 85,7 & 1 & 14,3 & 7 & 100,0 \\
$1805-1888$ & 335 & 40,4 & 495 & 59,6 & 830 & \\
\hline
\end{tabular}

FONTES: Livros de batismos de escravos da Ilha Grande de 1805-1847 e de 1850-1861; Livro de batismos de ingênuos da Ilha Grande, 1872-1888; Livro de batismos de escravos de Mambucaba, 1830-1871; Livro de batismos de escravos da Ribeira, 1824-1826; e Livro de batismos, casamentos e óbitos de escravos e de livres de Jacuecanga, 18001888. Convento do Carmo e Igreja de Jacuecanga, Angra dos Reis, RJ.

NOTA: Em 91 cerimônias não constavam os nomes dos proprietários.

Quando as mães solteiras convidavam escravas para serem suas comadres, estas eram, geralmente, cativas de outros senhores, em 59,6\% dos sacramentos. Comadres e mães de igual senhor foram representadas em 40,4\%.

Com exceção de 1872-1888, em todos os demais subperíodos, as madrinhas escravas pertenciam a propriedades diferentes.

Nos anos de 1805-1848, cativas de mesmo proprietário foram representadas em 41,8\% dos sacramentos e, entre 1849-1888, em 39,3\%. As comadres de diferente senhor compareceram a $58,2 \%$ e $60,7 \%$, respectivamente.

Cruzando os percentuais presentes no parágrafo anterior com aqueles encontrados para as madrinhas escravas, concluímos que o aumento da participação de mulheres cativas, como comadres, foi acompanhado pela elevação do convite feito às escravas de outros senhores. Ou seja, enquanto as madrinhas escravas de legítimos foram, cada vez mais, encontradas nas propriedades dos pais, as madrinhas cativas das crianças naturais foram buscadas em propriedades diferentes.

As mães solteiras, ao longo da segunda metade dos oitocentos, convidaram mais padrinhos escravos, muitos de outras propriedades ${ }^{167}$. Esta atitude foi semelhante no que se refere às madrinhas, quando muitas eram de outras escravarias.

167 Entretanto, as mães solteiras continuaram preferindo padrinhos livres, mas houve uma redução percentual dos mesmos e uma elevação dos convites feitos aos escravos. 
Portanto, com o avanço dos anos, as famílias ilegítimas foram agindo de forma semelhante às legítimas, ou seja, desejando associar-se aos membros da comunidade escrava, embora, no caso das primeiras, os cativos fossem buscados em outras propriedades.

TABELA 73

Origens dos pais de crianças escravas e ingênuas legítimas e das madrinhas por subperíodos. Angra dos Reis, 1805-1888

\begin{tabular}{c|c|c|c|c|c|c|c|c}
\hline ExMxMA & $\begin{array}{c}1805-1815 \\
\mathrm{n}^{\circ}(\%)\end{array}$ & $\begin{array}{c}1816-1826 \\
\mathrm{n}^{\circ}(\%)\end{array}$ & $\begin{array}{c}1827-1837 \\
\mathrm{n}^{\circ}(\%)\end{array}$ & $\begin{array}{c}1838-1848 \\
\mathrm{n}^{\circ}(\%)\end{array}$ & $\begin{array}{c}1849-1859 \\
\mathrm{n}^{\circ}(\%)\end{array}$ & $\begin{array}{c}1860-1871 \\
\mathrm{n}^{\circ}(\%)\end{array}$ & $\begin{array}{c}1872-1888 \\
\mathrm{n}^{\circ}(\%)\end{array}$ & $\begin{array}{c}1805-1888 \\
\mathrm{n}^{\circ}(\%)\end{array}$ \\
\hline AxAxA & $4(66,6)$ & $18(54,5)$ & $22(47,8)$ & $13(41,9)$ & $18(16,1)$ & 0 & 0 & $75(30,7)$ \\
CxCxC & $1(16,7)$ & $2(6,1)$ & $4(8,7)$ & 0 & $47(41,9)$ & $3(50,0)$ & $2(20,0)$ & $59(24,2)$ \\
Endogamia & $5(83,3)$ & $20(60,6)$ & $26(56,5)$ & $13(41,9)$ & $65(58,0)$ & $3(50,0)$ & $2(20,0)$ & $134(54,9)$ \\
AxAxC & 0 & $5(15,1)$ & $10(21,7)$ & $8(25,8)$ & $7(6,2)$ & $1(16,6)$ & 0 & $31(12,7)$ \\
AxCxA & $1(16,7)$ & $1(3,0)$ & $4(8,7)$ & $2(6,5)$ & $1(0,9)$ & 0 & 0 & $9(3,7)$ \\
AxCxC & 0 & $1(3,0)$ & $1(2,2)$ & $1(3,2)$ & $3(2,7)$ & 0 & 0 & $6(2,4)$ \\
CxAxA & 0 & $5(15,1)$ & $3(6,5)$ & $4(12,9)$ & $21(18,8)$ & $1(16,6)$ & $1(10,0)$ & $35(14,3)$ \\
CxAxC & 0 & $1(3,0)$ & $2(4,3)$ & $3(9,7)$ & $15(13,4)$ & $1(16,6)$ & $7(70,0)$ & $29(11,9)$ \\
Exogamia & $1(16,7)$ & $13(39,4)$ & $20(43,5)$ & $18(58,1)$ & $47(42,0)$ & $3(50,0)$ & $8(80,0)$ & $110(45,1)$ \\
Total & $6(100,0)$ & $33(100,0)$ & $46(100,0)$ & $31(100,0)$ & $112(100,0)$ & $6(100,0)$ & $10(100,0)$ & $244(100,0)$ \\
\hline
\end{tabular}

FONTES: Livros de batismos de escravos da Ilha Grande de 1805-1847 e de 1850-1861; Livro de batismos de ingênuos da Ilha Grande, 1872-1888; Livro de batismos de escravos de Mambucaba, 1830-1871; Livro de batismos de escravos da Ribeira, 1824-1826; e Livro de batismos, casamentos e óbitos de escravos e de livres de Jacuecanga, 18001888. Convento do Carmo e Igreja de Jacuecanga, Angra dos Reis, RJ.

NOTAS: E=Esposa; M=Marido; MA=Madrinha. Em 372 cerimônias não constavam informações acerca de um dos participantes, mães, pais ou madrinhas.

Em 54,9\% dos batismos, pais e madrinhas tinham a mesma origem. Isto é, havia uma ligeira preferência pela endogamia. Entretanto, se acompanharmos os dados ao longo do tempo, observamos variações: de 1805-1837, a endogamia africana foi predominante; entre 1838-1848, a exogamia chegou a 58,1\%; e de 1849-1888, os sacramentos envolveram, preferencialmente, pais e comadres nascidos no Brasil e, em menor escala, cativos crioulos e africanos.

Estes movimentos estão associados às mudanças demográficas verificadas em Angra dos Reis. Na localidade, a população cativa, ao longo do século XIX, tornou-se cada vez mais crioula. Isto resultava dos nascimentos e do término da entrada de africanos, após 1850. 
TABELA 74

Origens das mães de crianças escravas e ingênuas ilegítimas e das madrinhas por subperíodos.

Angra dos Reis, 1805-1888

\begin{tabular}{c|c|c|c|c|c|c|c|c}
\hline MxMA & $\begin{array}{c}1805-1815 \\
\mathrm{n}^{\circ}(\%)\end{array}$ & $\begin{array}{c}1816-1826 \\
\mathrm{n}^{\circ}(\%)\end{array}$ & $\begin{array}{c}1827-1837 \\
\mathrm{n}^{\circ}(\%)\end{array}$ & $\begin{array}{c}1838-1848 \\
\mathrm{n}^{\circ}(\%)\end{array}$ & $\begin{array}{c}1849-1859 \\
\mathrm{n}^{\circ}(\%)\end{array}$ & $\begin{array}{c}1860-1871 \\
\mathrm{n}^{\circ}(\%)\end{array}$ & $\begin{array}{c}1872-1888 \\
\mathrm{n}^{\circ}(\%)\end{array}$ & $\begin{array}{c}1805-1888 \\
\mathrm{n}^{\circ}(\%)\end{array}$ \\
\hline AxA & $3(27,3)$ & $34(47,2)$ & $39(50,0)$ & $29(44,6)$ & $61(27,2)$ & $5(6,9)$ & 0 & $171(32,3)$ \\
CxC & $4(36,4)$ & $11(15,3)$ & $9(11,5)$ & $8(12,3)$ & $69(30,8)$ & $39(54,2)$ & $4(57,1)$ & $144(27,2)$ \\
Endogamia & $7(63,6)$ & $45(62,5)$ & $48(61,5)$ & $37(56,9)$ & $130(58,0)$ & $44(61,1)$ & $4(57,1)$ & $315(59,5)$ \\
AxC & $3(27,3)$ & $18(25,0)$ & $22(28,2)$ & $22(33,8)$ & $58(25,9)$ & $13(18,1)$ & 0 & $136(25,7)$ \\
CxA & $1(9,0)$ & $9(12,5)$ & $8(10,2)$ & $6(9,2)$ & $36(16,1)$ & $15(20,8)$ & $3(42,9)$ & $78(14,7)$ \\
Exogamia & $4(36,4)$ & $27(37,5)$ & $30(38,5)$ & $28(43,1)$ & $94(42,0)$ & $28(38,9)$ & $3(42,9)$ & $214(40,5)$ \\
Total & $11(100,0)$ & $72(100,0)$ & $78(100,0)$ & $65(100,0)$ & $224(100,0)$ & $72(100,0)$ & $7(100,0)$ & $529(100,0)$ \\
\hline
\end{tabular}

FONTES: Livros de batismos de escravos da Ilha Grande de 1805-1847 e de 1850-1861; Livro de batismos de ingênuos da Ilha Grande, 1872-1888; Livro de batismos de escravos de Mambucaba, 1830-1871; Livro de batismos de escravos da Ribeira, 1824-1826; e Livro de batismos, casamentos e óbitos de escravos e de livres de Jacuecanga, 18001888. Convento do Carmo e Igreja de Jacuecanga, Angra dos Reis, RJ.

NOTAS: M=Mãe; MA=Madrinha. Em 1.291 cerimônias faltaram as indicações quanto às origens de mães ou de madrinhas.

Nos anos de 1805 a 1888, madrinhas e mães de igual origem estiveram presentes em 59,5\% dos batismos, com predomínio das africanas. Já comadres de diferentes origens compareceram a 40,5\% dos sacramentos.

Entre 1805-1848, a endogamia africana foi a mais comum. De 1849 em diante, com o aumento da população crioula, os laços de compadrio envolveram mulheres nascidas em terras brasileiras. Por conseguinte, independentemente da condição conjugal dos pais, aos olhos da Igreja, a escolha de madrinhas esteve condicionada às mudanças demográficas vividas pela escravaria local.

Em resultado, independentemente da legitimidade e do fato se serem padrinhos e madrinhas, caminhou-se para um quadro de endogamia crioula e, em menor escala, à exogamia.

Portanto, as crianças analisadas foram predominantemente ilegítimas. A ilegitimidade se tornou comum ao longo do tempo, passando de 69,1\%, entre 1805-1849, para $87,0 \%$ dos batizandos, entre 1872-1888.

As crianças foram batizadas, geralmente, até os seis meses de vida. E, na medida em que a idade aumentava, a freqüência de batizandos diminuía. Isto ocorreu em função da relativa urgência dos pais e, de seus senhores, com a conversão ao cristianismo.

O batismo de crianças legítimas foi caracterizado até 1871 por padrinhos e madrinhas escravos. Padrinhos, madrinhas e afilhados de mesma propriedade foram 
comuns nestas cerimônias, embora tenha havido pais que requisitassem cativos de outras propriedades.

As famílias legitimadas que fizeram do ritual do batismo o momento para o estabelecimento de laços com outros cativos de mesmo plantel deveriam, possivelmente, pertencer a médias ou grandes propriedades.

Em menor número, mas não menos importante, foram os padrinhos e madrinhas escravos pertencentes a outras propriedades. Isso representava a opção pelo alargamento dos conhecimentos e contatos daquelas famílias para além das propriedades em que viviam. Seus senhores poderiam ser, por exemplo, vizinhos ou até mesmo parentes.

Entretanto, houve uma participação importante dos padrinhos livres. As famílias que se associavam em compadrio com homens e mulheres livres, buscavam ampliar o raio de ação de suas famílias para além da comunidade à qual pertenciam. Quem sabe algumas dessas famílias já tinham uma intensa rede de contatos entre os seus "irmãos" de cativeiro e estavam vivendo um processo de abertura rumo ao universo livre? Poderiam ser famílias já fixadas na região há algum tempo e que fizeram do compadrio um meio de criar contatos com homens e mulheres livres.

Após 1872, padrinhos livres foram comuns nos batismos de ingênuos legítimos. Neste caso, o aumento da participação daqueles esteve vinculado à diminuição dos escravos nas propriedades e ao aumento da aproximação com a comunidade livre.

Entre as madrinhas, as mulheres escravas também foram mais comuns, sendo muitas pertencentes às propriedades de seus compadres.

As famílias formadas por mães solteiras escolhiam, em todos os subperíodos, predominantemente, padrinhos livres. Já as madrinhas livres foram comuns nos anos até 1837 e de 1872-1888. Em outras palavras, quando as mães solteiras optam por compadres e comadres, convidavam indivíduos em situação social superior, tendo entre eles, alguns proprietários de outros escravos, tenentes, capitães, alferes etc. Entre as madrinhas, além de escravistas, também estavam mulheres que tinham à frente de seus nomes a classificação de Dona.

Muitas mães solteiras deveriam estar em convívio com homens e mulheres livres, o que gerava uma aproximação entre eles, amizades e afetividades. Muitas deveriam viver em propriedades com reduzido número de escravos, facilitando seus contatos com, 
por exemplo, parentes de seus proprietários. De qualquer forma, estavam vivenciando um processo de ampliação das redes familiares para além de sua comunidade.

Após 1872, padrinhos livres foram comuns entre os ingênuos. No caso, além das idéias já lançadas, a preferência por eles resultava da diminuição do número de escravos, intensificada naqueles anos.

Gradativamente, a participação de madrinhas livres diminuiu e elevou-se a referência às escravas. Este movimento veio acompanhado pela maior freqüência no convite feito às mulheres pertencentes a outras propriedades.

Embora menos freqüente, houve mães solteiras que convidaram escravos para participar do batismo de seus filhos. Foram mulheres que optaram por reforçar seus vínculos na própria comunidade. Quando seus compadres e comadres eram escravos, tenderam a pertencer a outras propriedades, até 1871. Tal tendência representou uma das etapas relativas ao compadrio, que iniciava-se com associações dentro do grupo de escravos de um mesmo senhor, comum entre os legítimos. Posteriormente havia a abertura de compadrio envolvendo escravos de outros proprietários e homens e mulheres livres, as duas últimas freqüentes entre as famílias formadas por mães solteiras. Evidentemente, tal processo esteve diretamente relacionado ao tamanho das propriedades em que as famílias viviam. Propriedades com número reduzido de escravos, independentemente da condição de legitimidade daquelas famílias, acabavam por facilitar o contato entre escravos e livres.

Não obstante as diferenças verificadas entre as famílias legítimas e ilegítimas, ambas convidavam, mais e mais, escravos para participar do batismo de seus filhos. Comparando os informes para os anos de 1805-1848 e de 1849 até 1888, observamos um aumento na incidência de compadres e comadres escravos. Em meio às transformações verificadas com a chegada da segunda metade dos oitocentos, as famílias preocuparam-se em buscar protetores cativos para seus filhos.

No entanto, os pais convidavam cativos que viviam em suas propriedades e as mães solteiras, cativos de outros senhores. É conveniente considerar que, assim como a formação de laços de compadrio entre os escravos, foi-se estabelecendo uma comunidade cativa que ia além das propriedades. Idéia aceitável, já que o número de escravos estava 
diminuindo e houve a elevação percentual da população crioula. Tais questões são vistas no capítulo seguinte. 


\section{CAPÍTULO 10-OS PAIS ESPIRITUAIS}

Buscamos captar toda a extensão dos laços de compadrio e de apadrinhamento. Temos a intenção de encontrar indícios que demonstrem que o grau de pertencimento a uma família chegava até os "protetores espirituais” de crianças batizandas (GÓES, 1993; VASCONCELLOS, 2001). Observamos, também, a freqüência de afilhados crianças e

adultos por padrinhos e madrinhas, analisando a pulverização dos laços criados; e avaliamos a ligação estabelecida por diferentes propriedades no momento do apadrinhamento.

Através do uso dos registros de batismos verificamos que as famílias escravas iam além da consangüinidade e do matrimônio, envolvendo também padrinhos e madrinhas. Estes tenderam a ter, majoritariamente, um afilhado, o que demonstra que o momento do batismo era usado para o estabelecimento de vínculos com diferentes indivíduos e, conseqüentemente, alargar ainda mais os contatos e conhecimentos. Os sacramentos ofereciam uma oportunidade de "oficializar" laços de amizade entre indivíduos de mesmo destino, a escravidão, mas que pertenciam a donos diferentes, e indivíduos de mundos diversos, a escravidão e a liberdade.

A verificação dos nomes dados aos batizandos permite que cheguemos às "fronteiras máximas do sentimento de pertencer a uma família entre escravos" (FLORENTINO \& GÓES, 1997, p. 81). Comparando-se os nomes das crianças com os de seus pais, mães, tios, avós, padrinhos e madrinhas, podemos notar até onde iam as percepções de pertencimento à família, determinando, também, visões de mundo, acontecimentos e experiências (FLORENTINO \& GÓES, 1997, p. 82).

Nas folhas seguintes, foram analisados os nomes dados às crianças, comparandoos aos nomes de pais, padrinhos e madrinhas. 
TABELA 75

Nomes de batizandos crianças e ingênuos legítimos do sexo masculino, pais, mães, padrinhos e madrinhas por subperíodos. Angra dos Reis, 1805-1888

\begin{tabular}{|c|c|c|c|c|c|c|c|c|c|c|}
\hline \multirow{2}{*}{ Subperíodos } & \multicolumn{2}{|c|}{ Pai } & \multicolumn{2}{|c|}{ Mãe } & \multicolumn{2}{|c|}{ Padrinho } & \multicolumn{2}{|c|}{ Madrinha } & \multicolumn{2}{|c|}{ Total } \\
\hline & $\mathrm{n}^{\mathrm{o}}$ & $\%$ & $\mathrm{~N}^{\mathrm{o}}$ & $\%$ & $n^{o}$ & $\%$ & $n^{\circ}$ & $\%$ & $n^{o}$ & $\%$ \\
\hline $1805-1815$ & 1 & 14,3 & 0 & & 5 & 71,4 & 1 & 14,3 & 7 & 100,0 \\
\hline 1816-1826 & 2 & 28,6 & 2 & 28,6 & 2 & 28,6 & 1 & 14,3 & 7 & 100,0 \\
\hline 1827-1837 & 3 & 50,0 & 0 & & 2 & 33,3 & 1 & 16,7 & 6 & 100,0 \\
\hline 1838-1848 & 0 & & 0 & & 3 & 100,0 & 0 & & 3 & 100,0 \\
\hline 1849-1859 & 1 & 50,0 & 0 & & 1 & 50,0 & 0 & & 2 & 100,0 \\
\hline $1860-1871$ & 0 & & 0 & & 0 & & 0 & & 0 & \\
\hline $1872-1888$ & 1 & 33,3 & 0 & & 2 & 66,7 & 0 & & 3 & 100,0 \\
\hline Total & 8 & 28,6 & 2 & 7,1 & 15 & 53,6 & 3 & 10,7 & 28 & 100,0 \\
\hline
\end{tabular}

FONTES: Livros de batismos de escravos da Ilha Grande, 1805-1847 e de 1850-1861; Livro de batismos de ingênuos da Ilha Grande, 1872-1888; Livro de batismos escravos de Mambucaba, 1830-1871; Livro de batismos de escravos da Ribeira, de 1824-1826; e Livro de batismos, casamentos e óbitos de escravos e livres de Jacuecanga, 1800-1888. Convento do Carmo e Igreja de Jacuecanga, Angra dos Reis, RJ.

Em 28 batismos, os pais de crianças legítimas do sexo masculino homenagearam alguns dos genitores ou protetores espirituais. Geralmente optava-se pelo uso do nome dos padrinhos, em 53,6\%, seguido pelo nome de pais, madrinhas e, por último, das mães.

Nas 27 cerimônias que envolveram crianças legítimas do sexo feminino, os nomes das madrinhas foram escolhidos em 48,2\% dos sacramentos. Padrinhos, mães e pais também foram lembrados.

\section{TABELA 76}

Nomes de batizandos crianças e ingênuos legítimos do sexo feminino, pais, mães, padrinhos e madrinhas por subperíodos. Angra dos Reis, 1805-1888

\begin{tabular}{|c|c|c|c|c|c|c|c|c|c|c|}
\hline \multirow{2}{*}{ Subperíodos } & \multicolumn{2}{|c|}{ Pai } & \multicolumn{2}{|c|}{ Mãe } & \multicolumn{2}{|c|}{ Padrinho } & \multicolumn{2}{|c|}{ Madrinha } & \multicolumn{2}{|c|}{ Total } \\
\hline & $\mathrm{n}^{0}$ & $\%$ & $\mathrm{~N}^{\mathrm{o}}$ & $\%$ & $n^{0}$ & $\%$ & $n^{o}$ & $\%$ & $\mathrm{n}^{\mathrm{o}}$ & $\%$ \\
\hline $1805-1815$ & 0 & & 2 & 28,6 & 2 & 28,6 & 3 & 42,8 & 7 & 100,0 \\
\hline 1816-1826 & 1 & 10,0 & 2 & 20,0 & 3 & 30,0 & 4 & 40,0 & 10 & 100,0 \\
\hline 1827-1837 & 0 & & 0 & & 2 & 40,0 & 3 & 60,0 & 5 & 100,0 \\
\hline 1838-1848 & 0 & & 0 & & 0 & & 0 & & 0 & \\
\hline 1849-1859 & 0 & & 0 & & 1 & 25,0 & 3 & 75,0 & 4 & 100,0 \\
\hline 1860-1871 & 0 & & 1 & 100,0 & 0 & & 0 & & 1 & 100,0 \\
\hline 1872-1888 & 0 & & 0 & & 0 & & 0 & & 0 & \\
\hline Total & 1 & 3,7 & 5 & 18,5 & 8 & 29,6 & 13 & 48,2 & 27 & 100,0 \\
\hline
\end{tabular}

FONTES: Livros de batismos de escravos da Ilha Grande, 1805-1847 e de 1850-1861; Livro de batismos de ingênuos da Ilha Grande, 1872-1888; Livro de batismos escravos de Mambucaba, 1830-1871; Livro de batismos de escravos da Ribeira, de 1824-1826; e Livro de batismos, casamentos e óbitos de escravos e livres de Jacuecanga, 1800-1888. Convento do Carmo e Igreja de Jacuecanga, Angra dos Reis, RJ. 
Quando os pais fizeram do batismo de seus filhos um momento para homenagens, prestigiaram padrinhos e madrinhas. Os padrinhos "emprestavam” seus nomes a seus afilhados do sexo masculino e, as madrinhas, às afilhadas.

Em outras cerimônias, os inocentes legítimos receberam os nomes de seus pais, deixando implícito a preocupação com a memória da família, com a necessidade e a opção por propagar a lembrança familiar.

\section{TABELA 77}

Nomes de batizandos crianças e ingênuos ilegítimos do sexo masculino, mães, padrinhos e madrinhas por subperíodos. Angra dos Reis, 1805-1888

\begin{tabular}{|c|c|c|c|c|c|c|c|c|}
\hline \multirow{2}{*}{ Subperíodos } & \multicolumn{2}{|c|}{ Mãe } & \multicolumn{2}{|c|}{ Padrinho } & \multicolumn{2}{|c|}{ Madrinha } & \multicolumn{2}{|c|}{ Total } \\
\hline & $\mathrm{n}^{\mathrm{o}}$ & $\%$ & $\mathrm{n}^{\mathrm{o}}$ & $\%$ & $\mathrm{n}^{\mathrm{o}}$ & $\%$ & $\mathrm{n}^{\mathrm{o}}$ & $\%$ \\
\hline $1805-1815$ & 1 & 16,7 & 4 & 66,6 & 1 & 16,7 & 6 & 100,0 \\
\hline 1816-1826 & 1 & 11,1 & 6 & 66,6 & 2 & 22,3 & 9 & 100,0 \\
\hline 1827-1837 & 4 & 25,0 & 12 & 75,0 & 0 & & 16 & 100,0 \\
\hline 1838-1848 & 2 & 22,2 & 7 & 77,8 & 0 & & 9 & 100,0 \\
\hline 1849-1859 & 3 & 20,0 & 10 & 66,6 & 2 & 13,4 & 15 & 100,0 \\
\hline 1860-1871 & 2 & 40,0 & 3 & 60,0 & 0 & & 5 & 100,0 \\
\hline 1872-1888 & 2 & 60,0 & 3 & 40,0 & 0 & & 5 & 100,0 \\
\hline Total & 15 & 23,1 & 45 & 69,2 & 5 & 7,7 & 65 & 100,0 \\
\hline
\end{tabular}

FONTES: Livros de batismos de escravos da Ilha Grande, 1805-1847 e de 1850-1861; Livro de batismos de ingênuos da Ilha Grande, 1872-1888; Livro de batismos escravos de Mambucaba, 1830-1871; Livro de batismos de escravos da Ribeira, de 1824-1826; e Livro de batismos, casamentos e óbitos de escravos e livres de Jacuecanga, 1800-1888. Convento do Carmo e Igreja de Jacuecanga, Angra dos Reis, RJ.

Em 69,2\% dos 65 batismos, os nomes de meninos naturais e seus padrinhos foram iguais. As mães foram homenageadas em $23,1 \%$ e as madrinhas, em 7,7\% dos sacramentos.

Tendência semelhante foi vista nas cerimônias envolvendo meninas. As madrinhas emprestaram seus nomes a 64,2\% das afilhadas presentes na tabela 78. 
TABELA 78

Nomes de batizandos crianças e ingênuos ilegítimos do sexo feminino, mães, padrinhos e madrinhas por subperíodos. Angra dos Reis, 1805-1888

\begin{tabular}{|c|c|c|c|c|c|c|c|c|}
\hline \multirow{2}{*}{ Subperíodos } & \multicolumn{2}{|c|}{ Mãe } & \multicolumn{2}{|c|}{ Padrinho } & \multicolumn{2}{|c|}{ Madrinha } & \multicolumn{2}{|c|}{ Total } \\
\hline & $n^{0}$ & $\%$ & $n^{o}$ & $\%$ & $n^{o}$ & $\%$ & $\mathrm{n}^{\mathrm{o}}$ & $\%$ \\
\hline $1805-1815$ & 0 & & 0 & & 0 & & 0 & \\
\hline 1816-1826 & 4 & 33,3 & 1 & 8,3 & 7 & 58,4 & 12 & 100,0 \\
\hline 1827-1837 & 5 & 25,0 & 2 & 10,0 & 13 & 65,0 & 20 & 100,0 \\
\hline 1838-1848 & 2 & 16,7 & 2 & 16,7 & 8 & 66,6 & 12 & 100,0 \\
\hline 1849-1859 & 2 & 8,7 & 6 & 26,1 & 15 & 65,2 & 23 & 100,0 \\
\hline 1860-1871 & 1 & 14,3 & 1 & 14,3 & 5 & 71,4 & 7 & 100,0 \\
\hline 1872-1888 & 1 & 14,3 & 2 & 28,6 & 4 & 57,1 & 7 & 100,0 \\
\hline Total & 15 & 18,5 & 14 & 17,3 & 52 & 64,2 & 81 & 100,0 \\
\hline
\end{tabular}

FONTES: Livros de batismos de escravos da Ilha Grande, 1805-1847 e de 1850-1861; Livro de batismos de ingênuos da Ilha Grande, 1872-1888; Livro de batismos escravos de Mambucaba, 1830-1871; Livro de batismos de escravos da Ribeira, de 1824-1826; e Livro de batismos, casamentos e óbitos de escravos e livres de Jacuecanga, 1800-1888. Convento do Carmo e Igreja de Jacuecanga, Angra dos Reis, RJ.

A prática do emprego dos nomes de pais, mãe, padrinhos e madrinhas aponta para uma das várias facetas da cerimônia batismal, isto é, a preocupação com a memória familiar, representada pelos parentes ritualísticos, padrinhos e madrinhas, e pelos nomes de pais e mães, o parentesco consangüíneo.

Em geral, optou-se por homenagear e reproduzir na memória de uma família, a figura de padrinhos e de madrinhas, se não eternizados, ao menos tornada viva por tempo maior que o da vida dos protetores.

Constatamos que as famílias escravas se abriram para além do matrimônio e da consangüinidade, englobando padrinhos e madrinhas. A prática de alguns pais em dar a seus filhos os nomes de seus compadres e comadres demonstrou a ampliação do raio de ação das famílias.

Portanto, padrinhos e madrinhas, além de se tornar pais espirituais de seus afilhados, adotaram laços de compadrio com os pais das crianças. Sabemos também que os cativos foram cada vez mais escolhidos para participar das cerimônias, num contexto de transformação econômica e demográfica, existente no Oitocentos. O compadrio garantiu, efetivamente, a ampliação dos conhecimentos das famílias? Mudando as palavras, fazia-se da cerimônia uma oportunidade para efetivar contatos com o maior número possível de indivíduos? 
Grande parte dos padrinhos tiveram apenas um afilhado. Isso é verdade entre os escravos, forros e livres. Foram, respectivamente, 70,3\%, 67,9\% e 77,5\% de indivíduos que receberam apenas um afilhado, tanto crianças quanto adultos. Logo, o ato do batismo foi um evento onde aproveitava-se para criar laços com um número diversificado de indivíduos.

\section{TABELA 79}

Freqüência de afilhados por padrinhos. Angra dos Reis, entre os anos de 1805 e 1888

\begin{tabular}{c|c|c|c|c|c|c|c|c|c|c|c|c}
\hline $\begin{array}{c}\mathrm{n}^{\mathrm{o}} \\
\text { afilha- } \\
\text { dos }\end{array}$ & $\begin{array}{c}\text { Pad } \\
\text { escra- } \\
\text { vo }\end{array}$ & $\begin{array}{c}\% \\
\text { Pad } \\
\text { escra- } \\
\text { vo }\end{array}$ & $\begin{array}{c}\text { Afilha- } \\
\text { dos de } \\
\text { escravo }\end{array}$ & $\begin{array}{c}\% \\
\text { Afilha- } \\
\text { dos de } \\
\text { escravo }\end{array}$ & $\begin{array}{c}\text { Pad } \\
\text { forro }\end{array}$ & $\begin{array}{c}\% \\
\text { Pad } \\
\text { forro }\end{array}$ & $\begin{array}{c}\text { Afilha- } \\
\text { dos de } \\
\text { forro }\end{array}$ & $\begin{array}{c}\% \\
\text { Afilha- } \\
\text { dos de } \\
\text { forro }\end{array}$ & $\begin{array}{c}\text { Pad } \\
\text { livres }\end{array}$ & $\begin{array}{c}\% \\
\text { Pad } \\
\text { livre }\end{array}$ & $\begin{array}{c}\text { Afilha- } \\
\text { dos de } \\
\text { livre }\end{array}$ & $\begin{array}{c}\% \\
\text { Afilha- } \\
\text { dos de } \\
\text { livre }\end{array}$ \\
\hline 1 & 707 & 70,3 & 707 & 42,9 & 91 & 67,9 & 91 & 42,9 & 1076 & 77,5 & 1076 & 53,1 \\
2 & 161 & 16,0 & 322 & 19,6 & 26 & 19,4 & 52 & 24,5 & 192 & 13,7 & 384 & 18,9 \\
3 & 64 & 6,4 & 192 & 11,7 & 10 & 7,5 & 30 & 14,2 & 60 & 4,3 & 180 & 8,9 \\
4 & 27 & 2,7 & 108 & 6,6 & 3 & 2,2 & 12 & 5,7 & 24 & 1,7 & 96 & 4,7 \\
5 & 21 & 2,1 & 105 & 6,4 & 2 & 1,5 & 10 & 4,7 & 16 & 1,2 & 80 & 3,9 \\
6 & 9 & 0,9 & 54 & 3,3 & 1 & 0,7 & 6 & 2,8 & 5 & 0,4 & 30 & 1,5 \\
7 & 5 & 0,5 & 35 & 2,1 & 0 & & 0 & & 4 & 0,3 & 28 & 1,4 \\
8 & 2 & 0,2 & 16 & 1,0 & 0 & & 0 & & 4 & 0,3 & 32 & 1,6 \\
9 & 3 & 0,3 & 27 & 1,6 & 0 & & 0 & & 1 & 0,07 & 9 & 0,4 \\
10 & 1 & 0,1 & 10 & 0,6 & 0 & & 0 & & 1 & 0,07 & 10 & 0,5 \\
11 & 1 & 0,1 & 11 & 0,7 & 1 & 0,7 & 11 & 5,2 & 2 & 0,2 & 22 & 1,1 \\
12 & 0 & & 0 & & 0 & & 0 & & 1 & 0,07 & 12 & 0,6 \\
13 & 1 & 0,1 & 13 & 0,8 & 0 & & 0 & & 0 & & 0 & \\
14 & 1 & 0,1 & 14 & 0,9 & 0 & & 0 & & 0 & & 0 & \\
15 & 1 & 0,1 & 15 & 0,9 & 0 & & 0 & & 0 & & 0 & \\
16 & 0 & & 0 & & 0 & & 0 & & 1 & 0,07 & 16 & 0,8 \\
17 & 1 & 0,1 & 17 & 1,0 & 0 & & 0 & & 0 & & 0 & \\
18 & 0 & & 0 & & 0 & & 0 & & 1 & 0,07 & 18 & 0,9 \\
34 & 0 & & 0 & & 0 & & 0 & & 1 & 0,07 & 34 & 1,7 \\
Total & 1005 & 100,0 & 1646 & 100,0 & 134 & 100,0 & 212 & 100,0 & 1.389 & 100,0 & 2.027 & 100,0 \\
\hline
\end{tabular}

FONTES: Livros de batismos de escravos da Ilha Grande, 1805-1847 e de 1850-1861; Livro de batismos de ingênuos da Ilha Grande, 1872-1888; Livro de batismos escravos de Mambucaba, 1830-1871; Livro de batismos de escravos da Ribeira, de 1824-1826; e Livro de batismos, casamentos e óbitos de escravos e livres de Jacuecanga, 1800-1888. Convento do Carmo e Igreja de Jacuecanga, Angra dos Reis, RJ.

NOTAS: Pad=Padrinho. Afilhados de escravos não contados corresponderam a 165 e 19, de livres. 
Mesmo quando os padrinhos tinham vários afilhados, poucos foram os que batizaram filhos de escravos de mesmo pai e/ou mãe. Entre os escravos, 49 (16,4\%) protetores o foram de mais de um filho de mesma família. Dois (4,6\%) forros apadrinharam irmãos e 44 homens livres foram escolhidos por uma mesma família para o apadrinhamento de seus filhos. Ou seja, o batismo garantiu a proliferação de vínculos parentais diversos, com variadas pessoas.

No entanto, houve indivíduos convidados a participar de várias cerimônias. Por exemplo, um mesmo cativo foi padrinho de 17 batizandos: Joaquim, crioulo, cativo de Antônio Pinto Soares de Oliveira ${ }^{168}$. Todos seus afilhados foram crianças localizadas na freguesia de Mambucaba, entre os anos de 1851 e 1857. Dos pais que estabeleceram vínculos de compadrio com Joaquim, apenas duas mães reforçaram o compadrio com ele. Isto é, o escravo foi padrinho de mais de um filho das respectivas mães.

Por que ele recebeu tantos convites? Ele possuía alguma importância entre os cativos? Seu proprietário tinha alguma posição importante na sociedade local?

Difícil avaliar a importância daquele cativo junto à comunidade. Sabemos que seu proprietário, segundo dados extraídos do Almanak Laemmert, era dono de loja de fazendas nos anos de 1864, 1866, 1868 e 1870, na freguesia de Mambucaba, e negociante de molhados e secos em 1856, 1860, 1862, 1864, 1866, 1868 e 1870, na mesma localidade.

Infelizmente não encontramos o inventário de Antônio Pinto Soares de Oliveira, mas os registros paroquiais de seus escravos deixam a impressão de que ele tinha um número reduzido de trabalhadores compulsórios. Sendo ele comerciante, possivelmente fixado na área urbana de Mambucaba, seus poucos cativos deveriam ter algum tipo de mobilidade; eles deveriam circular com relativa facilidade pelas ruas do "centro" da freguesia. Assim conheciam outros escravos. Este conhecimento e as amizades criadas poderiam ter feito de Joaquim um cativo "popular"; e, portanto, tão requisitado na hora do apadrinhamento.

$\overline{{ }^{168} \text { Os afilhados de Joaquim estão especificados no anexo } 4 .}$ 
No entanto, Francisco Eugênio de Moura, homem livre e natural de Santos, em São Paulo, teve 34 afilhados, entre 1847 e $1871^{169}$. Todas as cerimônias foram realizadas em Mambucaba.

Seu nome apareceu indicado no Almanak Laemmert dos anos de 1856, 1860, 1862, 1864 e 1866, na qualidade de alfaiate e, em 1878, como fabriqueiro, também em Mambucaba. Nos registros paroquiais, por sua vez, não apareceu como proprietário de escravos.

Excluindo dois afilhados adultos africanos e dois com idade indefinida, os demais eram crianças. Quatro famílias reforçaram os vínculos de compadrio com Francisco Eugênio de Moura: Josefa africana, cativa de Luis Antônio Paes de Almeida, convidou-o a ser seu compadre em duas cerimônias, em 1853 e 1854; Clara, crioula, proprietária de Manoel Pedro Gomes, teve três filhos apadrinhados por ele, nos anos de 1847, 1852 e 1854; Iria crioula, e seu marido, Marcelino, de origem incerta, escravos de Antônio Cordeiro da Silva Guerra, convidaram Francisco Eugênio de Moura, em três batismos de seus filhos; e Maria, de origem indefinida, e seu marido Ventura, pertencentes a José Jordão da Silva Vargas, também tiveram três de seus filhos apadrinhados por ele.

Entre as mulheres que em algum momento tornaram-se madrinhas, houve uma tendência, assim como entre os padrinhos, de receberem apenas um afilhado. Madrinhas escravas com um afilhado corresponderam a 70,4\% das protetoras e, respectivamente, $77,1 \%$ e $80,3 \%$, das mulheres forras e livres.

Isto significa que também os laços adotados com as madrinhas tendiam a ser “popularizados”, atingindo grande número de mulheres.

${ }^{169}$ No anexo 5, o leitor encontra a listagem de afilhados de Francisco Eugênio de Moura. 


\section{TABELA 80}

Freqüência de afilhados por madrinhas. Angra dos Reis, entre os anos de 1805 e 1888

\begin{tabular}{|c|c|c|c|c|c|c|c|c|c|c|c|c|}
\hline $\begin{array}{c}\mathrm{n}^{\circ} \\
\text { afilha- } \\
\text { dos }\end{array}$ & $\begin{array}{c}\text { Mad } \\
\text { escra- } \\
\text { va }\end{array}$ & $\begin{array}{c}\% \\
\text { Mad } \\
\text { escra- } \\
\text { va }\end{array}$ & $\begin{array}{l}\text { Afilha- } \\
\text { dos de } \\
\text { escrava }\end{array}$ & $\begin{array}{c}\% \\
\text { Afilha- } \\
\text { dos de } \\
\text { escrava }\end{array}$ & $\begin{array}{l}\text { Mad } \\
\text { forra }\end{array}$ & $\begin{array}{c}\% \\
\text { Mad } \\
\text { forra }\end{array}$ & $\begin{array}{l}\text { Afilha- } \\
\text { dos de } \\
\text { forra }\end{array}$ & $\begin{array}{c}\% \\
\text { Afilha- } \\
\text { dos de } \\
\text { forra }\end{array}$ & $\begin{array}{l}\text { Mad } \\
\text { livre }\end{array}$ & $\begin{array}{c}\% \\
\text { Mad } \\
\text { livre }\end{array}$ & $\begin{array}{l}\text { Afilha- } \\
\text { dos de } \\
\text { livre }\end{array}$ & $\begin{array}{c}\% \\
\text { Afilha- } \\
\text { dos de } \\
\text { livre }\end{array}$ \\
\hline 1 & 648 & 70,4 & 648 & 44,3 & 93 & 77,1 & 93 & 56,4 & 611 & 80,3 & 611 & 56,8 \\
\hline 2 & 161 & 17,5 & 322 & 21,9 & 18 & 14,8 & 36 & 21,8 & 86 & 11,3 & 172 & 16,0 \\
\hline 3 & 48 & 5,2 & 144 & 9,8 & 6 & 4,9 & 18 & 10,9 & 24 & 3,2 & 72 & 6,7 \\
\hline 4 & 29 & 3,1 & 116 & 7,9 & 2 & 1,6 & 8 & 4,8 & 15 & 1,9 & 60 & 5,7 \\
\hline 5 & 13 & 1,4 & 65 & 4,4 & 2 & 1,6 & 10 & 6,1 & 13 & 1,7 & 65 & 6,0 \\
\hline 6 & 11 & 1,2 & 66 & 4,5 & 0 & & 0 & & 4 & 0,5 & 24 & 2,2 \\
\hline 7 & 3 & 0,3 & 21 & 1,4 & 0 & & 0 & & 4 & 0,5 & 28 & 2,7 \\
\hline 8 & 3 & 0,3 & 24 & 1,6 & 0 & & 0 & & 1 & 0,1 & 8 & 0,7 \\
\hline 9 & 0 & & 0 & & 0 & & 0 & & 1 & 0,1 & 9 & 0,8 \\
\hline 10 & 1 & 0,1 & 10 & 0,7 & 0 & & 0 & & 0 & & 0 & \\
\hline 11 & 0 & & 0 & & 0 & & 0 & & 1 & 0,1 & 11 & 1,0 \\
\hline 12 & 3 & 0,3 & 36 & 2,5 & 0 & & 0 & & 0 & & 0 & \\
\hline 13 & 0 & & 0 & & 0 & & 0 & & 0 & & 0 & \\
\hline 14 & 1 & 0,1 & 14 & 0,9 & 0 & & 0 & & 1 & 0,1 & 14 & 1,3 \\
\hline Total & 921 & 100,0 & 1.466 & 100,0 & 121 & 100,0 & 165 & 100,0 & 761 & 100,0 & 1.074 & 100,0 \\
\hline
\end{tabular}

FONTES: Livros de batismos de escravos da Ilha Grande, 1805-1847 e de 1850-1861; Livro de batismos de ingênuos da Ilha Grande, 1872-1888; Livro de batismos escravos de Mambucaba, 1830-1871; Livro de batismos de escravos da Ribeira, de 1824-1826; e Livro de batismos, casamentos e óbitos de escravos e livres de Jacuecanga, 1800-1888. Convento do Carmo e Igreja de Jacuecanga, Angra dos Reis, RJ.

NOTAS: Mad=Madrinha. Faltaram 118 afilhados de escravos e 18, de livres.

Rosa, de origem incerta e cativa de Manoel José de Cespes ${ }^{170}$, compareceu a 14 batismos, todos realizados em Mambucaba, entre os anos de 1830 e 1843. No entanto, de seus afilhados, apenas quatro eram crianças. Dos batismos, 13 envolveram cativos pertencentes ao ajudante Manoel José Firme.

Entre as madrinhas, a reincidência também não foi comum: 39 (14,3\%) escravas foram madrinhas mais de uma vez, de crianças de uma mesma família; uma (3,6\%) e 16 (10,7\%), respectivamente, corresponderam às forras e às livres, na mesma situação.

\footnotetext{
${ }^{170}$ Manoel José de Cespes foi indicado no Almanak Laemmert de 1860, 1864, 1866, 1868 e de 1870, como fazendeiro e lavrador de café.
} 


\section{TABELA 81}

Contato entre plantéis no momento do batismo, oferecendo padrinhos.

Angra dos Reis, 1805-1888

\begin{tabular}{|c|c|c|}
\hline $\begin{array}{c}\mathrm{n}^{\mathrm{o}} \text { de padrinhos enviados } \\
\text { por plantéis }\end{array}$ & $\mathrm{n}^{\circ}$ de plantéis & $\begin{array}{c}\% \\
\text { plantéis }\end{array}$ \\
\hline 1 & 189 & 59,7 \\
\hline 2 & 45 & 14,3 \\
\hline 3 & 31 & 9,7 \\
\hline 4 & 15 & 4,7 \\
\hline 5 & 9 & 2,8 \\
\hline 6 & 7 & 2,2 \\
\hline 7 & 4 & 1,3 \\
\hline 8 & 3 & 0,9 \\
\hline 9 & 2 & 0,6 \\
\hline 10 & 1 & 0,3 \\
\hline 14 & 3 & 0,9 \\
\hline 17 & 1 & 0,3 \\
\hline 18 & 1 & 0,3 \\
\hline 19 & 1 & 0,3 \\
\hline 21 & 1 & 0,3 \\
\hline 23 & 1 & 0,3 \\
\hline 29 & 1 & 0,3 \\
\hline 32 & 1 & 0,3 \\
\hline 36 & 1 & 0,3 \\
\hline total & 317 & 100,0 \\
\hline
\end{tabular}

FONTES: Livros de batismos de escravos da Ilha Grande, 1805-1847 e de 1850-1861; Livro de batismos de ingênuos da Ilha Grande, 1872-1888; Livro de batismos escravos de Mambucaba, 1830-1871; Livro de batismos de escravos da Ribeira, de 1824-1826; e Livro de batismos, casamentos e óbitos de escravos e livres de Jacuecanga, 1800-1888. Convento do Carmo e Igreja de Jacuecanga, Angra dos Reis, RJ.

NOTAS: Noventa e cinco propriedades não enviaram padrinhos para outras escravarias. Em dois batismos não foi possível a identificação dos plantéis que ofereceram padrinhos.

Foram 412 plantéis que indicaram escravos para o apadrinhamento. Destes, 95 (23,1\%) não enviaram escravos para serem padrinhos de cativos a outros plantéis, e 317 $(76,9 \%)$ ofereceram padrinhos a outras propriedades. Isto é, os cativos de diferentes senhores se relacionavam com freqüência.

Dos plantéis que enviaram padrinhos, a maior parte só o fez uma única vez. Os contatos realizados entre diferentes propriedades, geralmente, se deram em apenas uma ocasião. No entanto, 40,3\% dos plantéis ofereceram escravos para o apadrinhamento duas 
ou mais vezes. Isto é, embora não fosse predominante, muitos escravos, pais de batizandos, de diferentes senhores, se relacionavam e faziam do batismo o momento para “oficializar” os laços de amizade, via compadrio, para além dos limites das propriedades em que viviam.

Quando observamos a tabela 81 encontramos quatro propriedades responsáveis por oferecer padrinhos a 109 cerimônias. Possivelmente tratavam-se de médias e grandes escravarias, detentoras de elevado número de escravos, e, portanto, com maior oferta de possíveis padrinhos. Os cativos de Júlio Dufrayer estiveram em 21 sacramentos, na qualidade de protetores espirituais. Por meio dos registros paroquiais, já que não temos em mãos seu inventário, verificamos que ele possuía muitos escravos. Somando os registros datados dos anos de 1830, 1840, 1850 e 1860, todos de Mambucaba, encontramos 59 cativos adultos, entre mães, pais, madrinhas e padrinhos.

Júlio Dufrayer, segundo os dados do Almanak Laemmert, era comerciante que, em seguida, começou a dedicar-se ao cultivo do café. Nos anos de 1848 e 1850 foi indicado como proprietário de um armazém de secos e molhados e de café. Nos anos pares da década de 1860, já era anunciado como fazendeiro e lavrador de café. Foi, possivelmente, um comerciante que, enriquecendo, passou a dedicar-se àquilo que era mais nobre, a terra, fazendo uso de um número considerável de escravos.

Ignácio During foi citado em 23 batismos como proprietário de padrinhos. Mais uma vez, as cerimônias foram realizadas em Mambucaba, nos anos de 1840, 1850, 1860 e 1870. No total foram 27 escravos, dentre batizandos adultos, pais e protetores. Segundo o Almanak Laemmert, Ignácio During era fazendeiro de café e proprietário de uma oficina de despolpadores e ventiladores de café, nos anos pares entre 1856 e 1878.

O capitão Pedro José Travassos, residente na Ilha Grande, foi indicado em 29 batismos, na qualidade de senhor de padrinhos, entre os anos de 1807 até a década de 1850. No Almanak Laemmert dos anos pares entre 1856 e 1860 foi citado como fazendeiro de café e fabricante de aguardente. Entre batizandos adultos, pais e protetores, foram contabilizados 84 cativos. Por certo, o capitão era, no mínimo, médio proprietário.

O último plantel que se destacou enviando 36 escravos para o compadrio pertenceu a José Jordão da Silva Vargas. 
As quatro propriedades indicadas tinham em comum o fato de congregar um relativo número de escravos e se relacionar com variadas escravarias no momento do batismo.

Na próxima página, o leitor pode verificar os vínculos adotados. 


\section{FIGURA 3}

Contatos entre as propriedades oferecendo padrinhos ${ }^{171}$

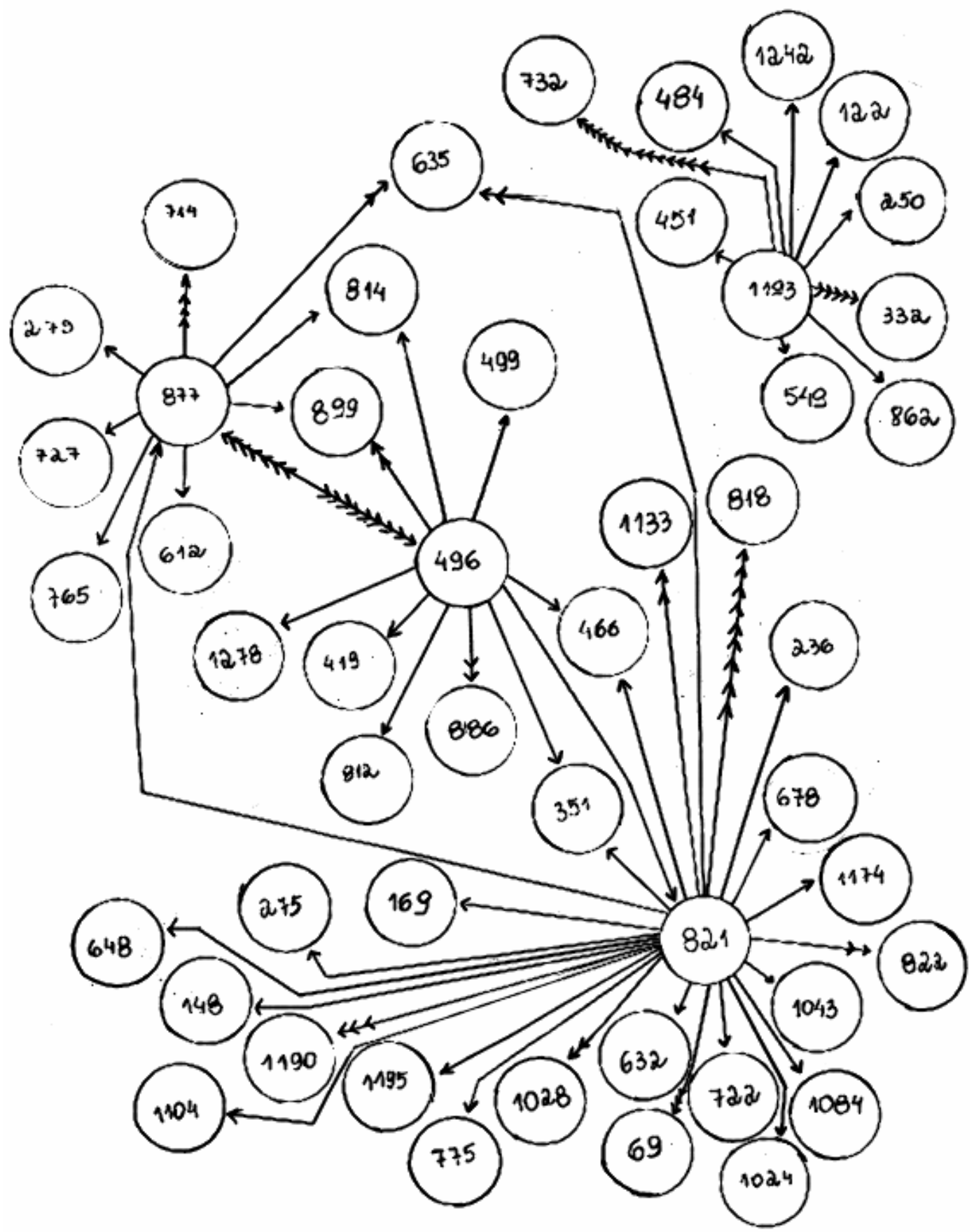

FONTES: Livros de batismos de escravos da Ilha Grande, 1805-1847 e de 1850-1861; Livro de batismos de ingênuos da Ilha Grande, 1872-1888; Livro de batismos escravos de Mambucaba, 1830-1871; Livro de batismos de escravos da Ribeira, de 1824-1826; e Livro de batismos, casamentos e óbitos de escravos e livres de Jacuecanga, 1800-1888. Convento do Carmo e Igreja de Jacuecanga, Angra dos Reis, RJ.

${ }^{171}$ Os nomes dos proprietários encontram-se no anexo 6. As setas indicam os escravos convidados para o apadrinhamento. 
A figura demonstra que os escravos de diferentes plantéis estabeleceram vínculos de compadrio. Por exemplo, os cativos de Júlio Dufrayer se relacionavam com os escravos de outros proprietários, incluindo os de Ignácio During e de José Jordão da Silva Vargas. Os cativos deste último, por sua vez, comunicavam-se, intensamente com os escravos de outros senhores. Ou seja, a população escrava estava em pleno processo de ampliação de amizades, assim como estava sendo formada uma comunidade escrava que ia além dos limites das propriedades.

Se recordarmos que as mães solteiras e os pais convidavam, ao longo do tempo, mais e mais cativos para o apadrinhamento, podemos pensar que, na segunda metade do século XIX, mesmo diante da diminuição numérica de escravos, estava havendo a ampliação dos laços entre eles, caracterizada, entre as famílias matrifocais, pela adoção do compadrio com indivíduos de outros plantéis. A figura 3 aponta para o intenso contato entre os escravos, contato este que se estabelecia entre crioulos, com a mesma história. 
TABELA 82

Contato entre plantéis no momento do batismo, oferecendo madrinhas. Angra dos Reis, 1805-1888

\begin{tabular}{c|c|c}
\hline $\begin{array}{c}\mathrm{n}^{0} \text { de madrinhas enviadas } \\
\text { por plantéis }\end{array}$ & $\mathrm{n}^{\text {o de plantéis }}$ & $\begin{array}{c}\% \\
\text { plantéis }\end{array}$ \\
\hline 1 & 179 & 59,6 \\
2 & 44 & 14,7 \\
3 & 23 & 7,7 \\
4 & 21 & 7,0 \\
5 & 9 & 3,0 \\
6 & 3 & 1,0 \\
7 & 8 & 2,7 \\
8 & 3 & 1,0 \\
9 & 1 & 0,3 \\
10 & 1 & 0,3 \\
12 & 1 & 0,3 \\
15 & 2 & 0,7 \\
16 & 1 & 0,3 \\
19 & 1 & 0,3 \\
27 & 1 & 0,3 \\
32 & 2 & 0,7 \\
Total & 300 & 100,0 \\
\hline
\end{tabular}

FONTES: Livros de batismos de escravos da Ilha Grande, 1805-1847 e de 1850-1861; Livro de batismos de ingênuos da Ilha Grande, 1872-1888; Livro de batismos escravos de Mambucaba, 1830-1871; Livro de batismos de escravos da Ribeira, de 1824-1826; e Livro de batismos, casamentos e óbitos de escravos e livres de Jacuecanga, 1800-1888. Convento do Carmo e Igreja de Jacuecanga, Angra dos Reis, RJ.

NOTA: Cem propriedades não enviaram madrinhas para outras escravarias ou não foi possível a identificação dos plantéis que ofereceram madrinhas.

De 400 propriedades que tiveram escravas na qualidade de madrinhas, 300 (75\%) plantéis se comunicaram via compadrio.

As propriedades enviaram, com maior freqüência, madrinhas para outras escravarias uma única vez. O percentual destas propriedades correspondeu a 59,6\%, portanto 40,4\% dos plantéis enviaram madrinhas duas ou mais vezes.

Por conseguinte, além das mulheres receberem, geralmente, um único afilhado, quando tratava-se de cativos que pertenciam a outros senhores, o convite tendia a ser feito uma única vez. 
No entanto, três propriedades destacaram-se no envio de madrinhas: o Capitão Pedro José Travassos foi citado em 27 batismos como proprietário de madrinhas; Ignácio During e José Jordão da Silva Vargas, contribuíram com 32 madrinhas, cada. Ou seja, foram as mesmas propriedades citadas entre os padrinhos. Os cativos daqueles senhores foram mais convocados para cerimônias exatamente porque, dentre outros motivos, detinham um número considerável de escravos ${ }^{172}$.

${ }^{172}$ A propriedade do Capitão Pedro José Travassos encontra-se separada das duas demais pois localizava-se na Ilha Grande. Já as duas outras encontravam-se em Mambucaba. 
FIGURA 4

Contatos entre as propriedades oferecendo madrinhas ${ }^{173}$

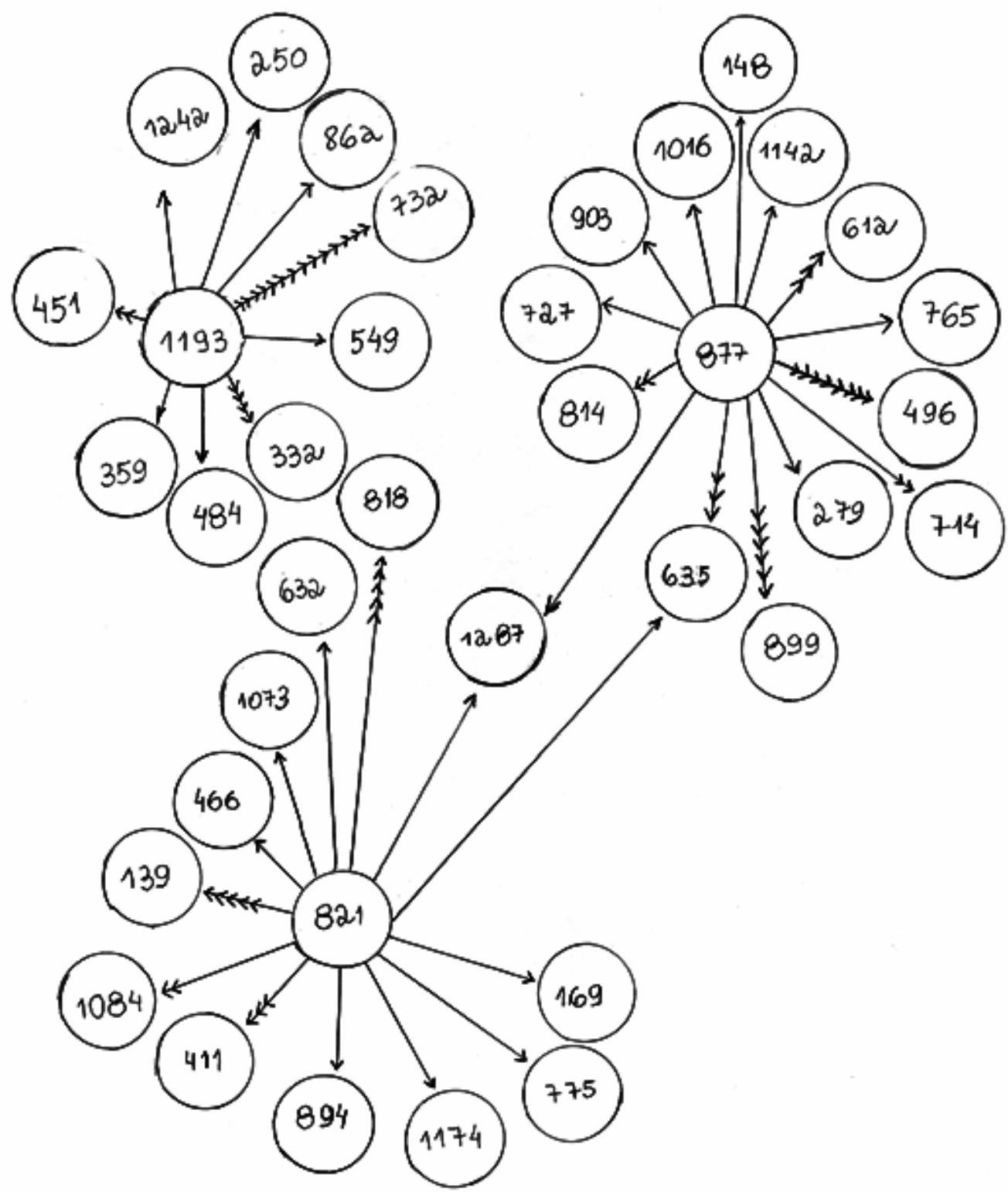

FONTES: Livros de batismos de escravos da Ilha Grande, 1805-1847 e de 1850-1861; Livro de batismos de ingênuos da Ilha Grande, 1872-1888; Livro de batismos escravos de Mambucaba, 1830-1871; Livro de batismos de escravos da Ribeira, de 1824-1826; e Livro de batismos, casamentos e óbitos de escravos e livres de Jacuecanga, 1800-1888. Convento do Carmo e Igreja de Jacuecanga, Angra dos Reis, RJ.

${ }^{173}$ Os nomes dos proprietários encontram-se no anexo 7. As setas correspondem às escravas que foram convidadas para o apadrinhamento. 
Observamos que os trabalhadores de Ignácio During e José Jordão da Silva Vargas possuíam amizades com escravos de outros senhores. Para haver tais trocas, evidentemente, eles deveriam ter liberdade de circulação. Sabemos que os cativos não viviam sem comunicação com o mundo externo e, diante de um contexto de diminuição do quantitativo nas propriedades, mais fácil seria que todos se conhecessem, tal como numa "cidade do interior".

Portanto, convidar padrinhos e madrinhas para seus filhos era mais do que uma formalidade. Isto é, os pais visavam com a adoção do compadrio, estabelecer ou reforçar laços de amizade e de solidariedade. Estes laços, por vezes, foram levados tão à sério, que os afilhados receberam os nomes de seus protetores, como resultado de uma preocupação em homenagear os compadres e comadres e torná-los vivos além do próprio tempo de vida de cada um deles. Os cativos reconheciam os protetores espirituais como membros das suas famílias. Portanto, tais famílias não se esgotavam nos vínculos matrimoniais e de consangüinidade. Elas se abriam e congregavam os parentes ritualísticos, no caso, os oriundos do batismo.

Aquela cerimônia era uma oportunidade para a ampliação dos conhecimentos dos escravos, por isso, as famílias escolhiam, geralmente, protetores diferentes para cada um de seus filhos. Por conseguinte, grande parte dos padrinhos e madrinhas tinham apenas um afilhado.

Observamos, finalmente, que havia uma interligação entre as várias propriedades. Isto significava que, independentemente de quem eram seus senhores, os escravos se conheciam e se relacionavam.

Estaríamos diante da formação de uma comunidade escrava formada por crioulos, muitos nascidos em Angra, que optaram, mais e mais, por estabelecer compadrio com outros na mesma situação de escravização, em meio a um quadro caracterizado por crise econômica e transformação demográfica, com o passar dos anos da segunda metade dos oitocentos.

Entretanto, os laços estabelecidos por eles não envolviam apenas o matrimônio, a consangüinidade direta ou o apadrinhamento. Veremos, a seguir que muitas crianças conviviam com avós, tios e demais parentes na mesma propriedade. Sem dúvida, 
pertencer a famílias extensas auxiliava homens e mulheres a melhor suportar a dura vida diária. 


\section{PARTE IV \\ ESTABILIDADE DAS FAMÍLIAS ESCRAVAS}

\section{INTRODUÇÃO}

Sendo o escravo, juridicamente, uma mercadoria, estava vulnerável às transações comerciais de compra e venda e poderia ser dado em pagamento por dívidas assumidas pelo seu senhor. Certamente, essas circunstâncias eram evitadas pelo proprietário, que não gostaria de perder seu “patrimônio”. No entanto, a realidade imperial baseava-se num constante processo de endividamento, onde os menos aquinhoados eram os mais prejudicados. Conseqüentemente, os cativos acabavam sendo um dos principais bens colocados como garantia de pagamento. E como ficava a família escrava neste contexto?

João da Cunha Machado, em seu inventário de 1851, possuía, na freguesia da Ribeira, quatro escravos ${ }^{174}$, pertencentes a uma única família encabeçada por Constância, africana. Ela contava com a companhia de três filhos. Porém, quando da abertura do processo, seus filhos foram arrematados, dois por Manoel Barbosa Guimarães, e o outro por José de Sousa Lima. Constância, por sua vez, foi encaminhada à uma das herdeiras.

O caso relatado demonstra que, mesmo que houvesse uma tendência a poupá-los, quando fosse necessário, eram postos em leilões em praça pública. E, em geral, como a família escrava era encarada no momento de partilha dos bens? A morte do senhor gerava ansiedade no cativo, pois era um dos eventos onde a sua face de mercadoria ficava exposta. Ele era visto pelo avaliador, que observava sua condição física, anotando doenças, maus hábitos, aptidão para o trabalho, etc.; para, em seguida, dar-lhe um valor. Posteriormente, toda a escravaria era distribuída entre os herdeiros. Enfim, as famílias eram respeitadas ou havia separações?

Esse é um dos temas tratados na parte IV: no capítulo 11, acompanhamos algumas famílias que conseguiram manter-se unidas por um bom tempo, demonstrando a

\footnotetext{
${ }^{174}$ Inventário de João da Cunha Machado, 1851. Angra dos Reis, RJ. Museu da Justiça do Estado do Rio de Janeiro, RJ.
} 
capacidade de preservação dos laços. Nesses grupos parentais encontramos avós, tios, filhos, sobrinhos, compartilhando do dia-a-dia.

Durante o trabalho de cruzamento dos registros paroquiais, dos inventários e das matrículas de escravos de $1872^{175}$, tivemos acesso também às famílias fraternas, formadas por irmãos que, por algum motivo, não estavam, no momento de realização do inventário, convivendo com seus pais.

No capítulo 12, examinamos os processos de partilha dos bens, constantes nos inventários, tendo em vista o comprometimento dos envolvidos - avaliadores e herdeiros - com as famílias escravas. Em nossa reflexão, dividimos os grupos parentais a partir do grau de legitimidade (famílias nucleares e matrifocais) e avaliamos como eles passaram por aquele evento. Em seguida, comparamos os dados para a primeira e a segunda metade dos oitocentos, procurando avaliar se houve mudanças no comportamento dos homens livres quanto à separação ou não de famílias.

Verificamos também o destino dado às famílias fraternas e extensas durante a distribuição dos escravos pelos herdeiros.

Nosso intento é provar, tanto por meio do capítulo 11 quanto pelo 12, que as famílias escravas conseguiram manter-se e conheceram relativa estabilidade. Esta estabilidade é observada mediante a existência de famílias extensas e a tendência à permanência dos grupos parentais durante a distribuição dos bens entre os herdeiros.

${ }^{175}$ Em 20 inventários encontra-se a relação de escravos matriculados, em 1872. 


\section{CAPÍTULO 11-AS FAMÍLIAS EXTENSAS}

Já foi o tempo em que a historiografia considerava que os escravos viviam em promiscuidade, sem parceiros fixos e vulneráveis às vontades de seus senhores. Nos capítulos anteriores, vimos diversas famílias formadas por mães, em tese, solteiras, com seus filhos. Outras mulheres eram casadas com alforriados e havia, ainda, aquelas unidas a "companheiros" de cativeiro. Além dos laços formados pela consangüinidade e pelo matrimônio, o parentesco "ritual", resultante do batismo, garantia o alargamento dos conhecimentos entre os escravos, envolvendo, inclusive, livres e forros.

Como resultado do cruzamento dos registros paróquias e cartorários, soubemos que 62 escravos que, aparentemente estavam sem parentes na propriedade, conviviam com seus irmãos, somando 18 famílias fraternas: entre 1827-1837, localizamos dois irmãos que não estavam mais em companhia de seus pais; entre 1849-1859, foram três irmãos; entre 1860-1871, 18, divididos em cinco famílias; e, de 1872 até 1888, 39 parentes, somando 11 famílias fraternas.

Os dados apresentados apontam para a importância de trabalharmos com diferentes documentos, e a possibilidade que as matrículas de escravos, de 1872, oferecem ao pesquisador. Não foi por menos que a maior parte das famílias fraternas foram encontradas após 1872. Por exemplo, no inventário de Dona Balbina Maria de Jesus Sousa ${ }^{176}$, de 1876, os avaliadores anotaram os nomes de dois escravos, Pedro crioulo, então com 25 anos, sem filiação, e Domingos, também crioulo, com 17 anos e sem indicação a parentes. Por meio do cruzamento do inventário com a matrícula de 1872, tivemos ciência que ambos eram irmãos e filhos de Rita, também presente na matrícula, entretanto, antes da morte de sua senhora, já havia sido vendida. Portanto, transcorridos quatro anos após a matrícula, os dois irmãos não viviam mais com sua genitora, todavia estavam juntos ${ }^{177}$.

\footnotetext{
${ }^{176}$ Inventário de Dona Balbina Maria de Jesus Sousa, 1876. Angra dos Reis, RJ. Museu da Justiça do Estado do Rio de Janeiro, RJ. A inventariada possuía 13 escravos, além de outras propriedades nas freguesias da Ribeira e de Angra dos Reis.

${ }^{177}$ Eles foram separados após a partilha.
} 
Encontramos dez famílias extensas ${ }^{178}$ : entre 1827-1837, localizamos duas famílias, envolvendo 13 parentes; entre 1838-1848, uma, com três indivíduos; entre 1860-1871, quatro, com 27 familiares; e entre 1872-1888, três, congregando 29 pessoas.

Francisco dos Santos Reis ${ }^{179}$, falecido em 1835, na freguesia da Ilha Grande, morava na Enseada da Estrela. Dedicado à agricultura, cultivava café, cana e frutas. Possuía um engenho de cana, rede de pesca, canoas, roda para cevar mandioca, etc. Para a realização de suas atividades, dispunha da ajuda de 54 cativos. Destes escravos, nove $(17, \%)$ pertenciam a uma única família encabeçada por Eva crioula, com 40 anos.

\footnotetext{
${ }^{178}$ Também foram localizadas após o cruzamento dos registros paroquiais, inventários, e, em alguns casos, após a avaliação das matrículas de escravos, de 1872.

${ }^{179}$ Inventário de Francisco dos Santos Reis, 1835. Angra dos Reis, RJ. Museu da Justiça do Estado do Rio de Janeiro, RJ.
} 


\section{FIGURA 5}

Família de Eva crioula, $1835^{180}$

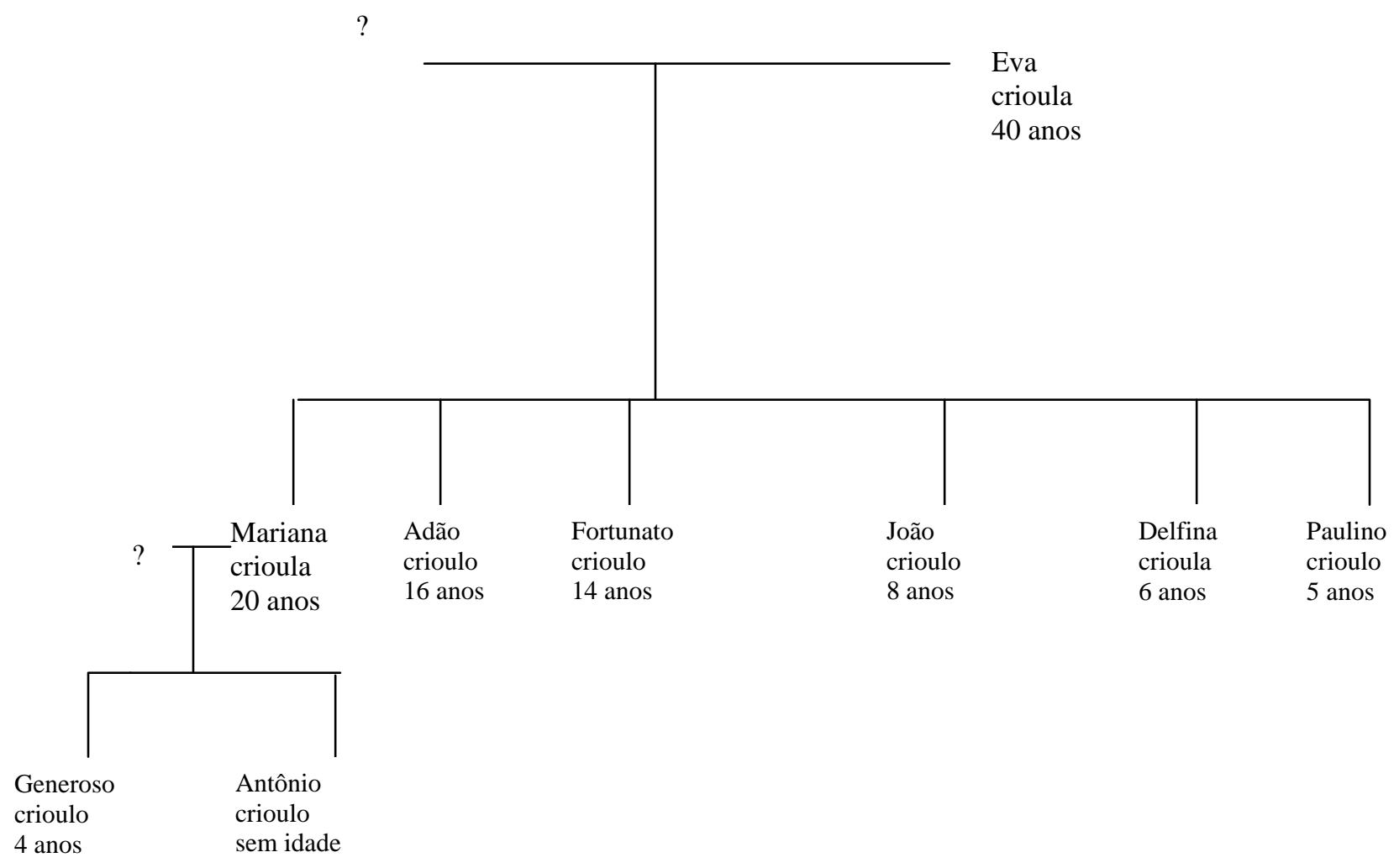

Eva era uma mulher “de sorte” pois contava, em 1835, com a presença de seus seis filhos e dois netos. Esta experiência para os escravos era extremamente valiosa pois eles, na qualidade de “peças”, estavam vulneráveis às vontades e necessidades senhoriais.

Contudo, infelizmente, no momento da partilha, a família foi separada: Eva ficou na presença de seu filho Paulino, de menor idade; Adão e João foram encaminhados para

\footnotetext{
${ }^{180}$ Os pontos de interrogação referem-se aos parentes não localizados e as idades foram localizadas nos documentos.
} 
um mesmo herdeiro ${ }^{181}$; Delfina foi enviada para outro filho do inventariado; Mariana e Fortunato permaneceram juntos, mas Mariana foi afastada de seu filho Generoso, enquanto Antônio falecera durante o inventário.

Localizamos outra família extensa, no ano de 1866, quando da morte de Maria Pires de Aguiar $^{182}$ : tratava-se da família de Catarina africana, com 45 anos. Ela, seus filhos e netos, vivam numa propriedade com 10 escravos, sendo que oito (80\%) eram parentes da africana.

\section{FIGURA 6}

Família de Catarina africana, $1862^{183}$

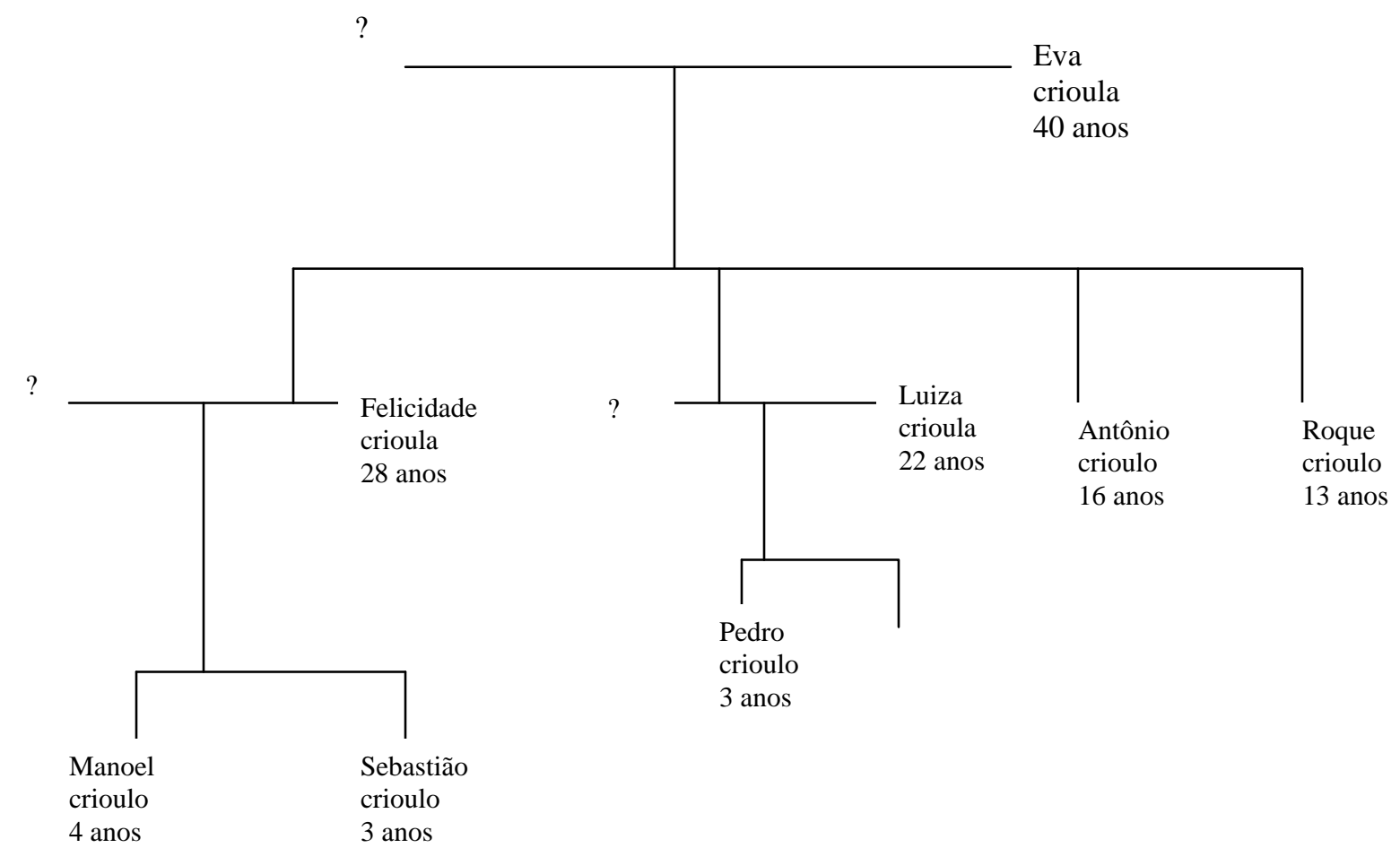

O exemplo da escravaria de Maria Pires de Aguiar é revelador: quase todos os seus cativos pertenciam a uma única família, a de Catarina africana. Isto demonstra que

\footnotetext{
${ }^{181}$ Formou-se uma família fraterna.

${ }^{182}$ Inventário de Maria Pires de Aguiar, 1866. Angra dos Reis, RJ. Museu da Justiça do Estado do Rio de Janeiro, RJ. A inventariada vivia na freguesia da Conceição, tinha metade da Ilha do Cavaco, na parte sul, uma casa e seus móveis, além de canoas e rede de pesca.

${ }^{183}$ Os pontos de interrogação referem-se aos parentes não localizados e as idades foram encontradas nos documentos.
} 
os parentes daquela escrava não tinham muitas opções quanto à escolha de parceiros. Por isso, Felicidade e sua irmã Luiza, possivelmente, participavam de uniões consensuais ou com escravos de outros senhores, ou com forros, ou com livres. A situação vivenciada por elas, com certeza, deveria ser uma constante entre os demais escravos de Angra dos Reis, ainda mais na segunda metade do século XIX, em meio à diminuição numérica de cativos no município.

Após a partilha, os parentes de Catarina africana foram separados: Felicidade foi herdada por uma filha da falecida, sendo separada de seus dois filhos, que ficaram em companhia dos tios Luiza, Antônio e Roque. O filho e a mãe de Luiza ficaram com o inventariado, viúvo de Dona Maria.

Diferentemente do que ocorreu com a família de Catarina, a de Isabel crioula foi mantida unida na partilha:

FIGURA 7

Família de Isabel crioula, $1871^{184}$

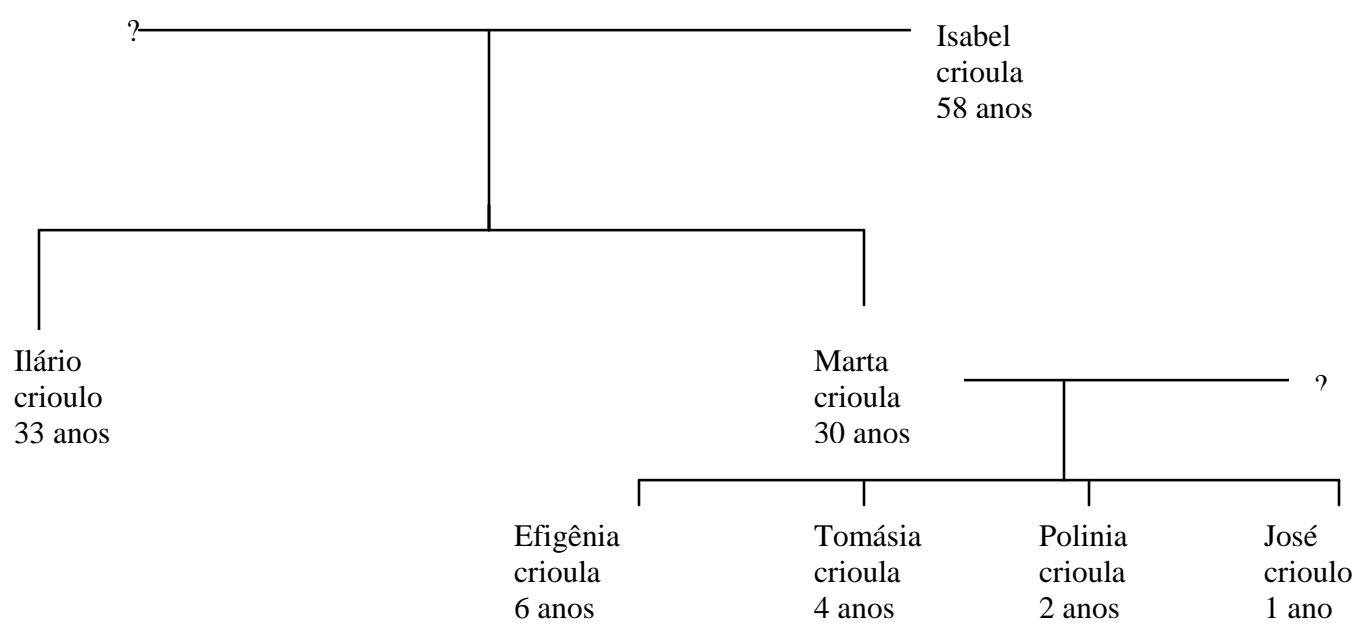

\footnotetext{
${ }^{184}$ Os pontos de interrogação correspondem aos parceiros não localizados e as idades foram encontradas nos documentos.
} 
Em 1871, Dona Teresa Cândida Alvim de Carvalho deu abertura ao inventário de seu falecido marido, Cândido Teixeira de Carvalho. O casal possuía 126 escravos distribuídos nas propriedades estabelecidas na Praia do Holandês e na Enseada da Estrela, na freguesia da Ilha Grande, e na área urbana da freguesia da Conceição ${ }^{185}$.

A família de Isabel vivia na Praia do Holandês, na Ilha Grande, e, no momento da partilha, foi uma das poucas famílias extensas que se manteve unida. Todos ficaram com a viúva que possuía três filhos.

A quarta família que gostaríamos de citar tinha à frente a escrava Maria crioula, de 55 anos. Ela, seus filhos e netos, pertenciam a José Constantino dos Santos, morador no Provetá, na Ilha Grande ${ }^{186}$. No ano de 1882, a viúva do inventariante, Dona Carolina Maria da Conceição, iniciou o processo de partilha dos bens, constituídos por cafeeiros, redes de pesca, canoas, rancho, roda de cevar mandioca e uma casa. Havia, ainda, sete escravos e três ingênuos. Em meio a estes, nove (90,0\%) faziam parte da família da cativa Maria crioula.

Temos mais um exemplo de escravaria formada basicamente por escravos pertencentes a uma mesma família. Por certo, isso fez com que Leopoldina se relacionasse com um indivíduo que não pertencia à propriedade.

\footnotetext{
${ }^{185}$ Inventário de Cândido Teixeira de Carvalho, 1871. Angra dos Reis, RJ. Museu da Justiça do Estado do Rio de Janeiro, RJ. Este inventário já foi citado no capítulo 3 e era um dos maiores, em números de escravos.

${ }^{186}$ Inventário de José Constantino dos Santos, 1882. Angra dos Reis, RJ. Museu da Justiça do Estado do Rio de Janeiro, RJ.
} 
FIGURA 8

Família de Maria crioula, $1882^{187}$

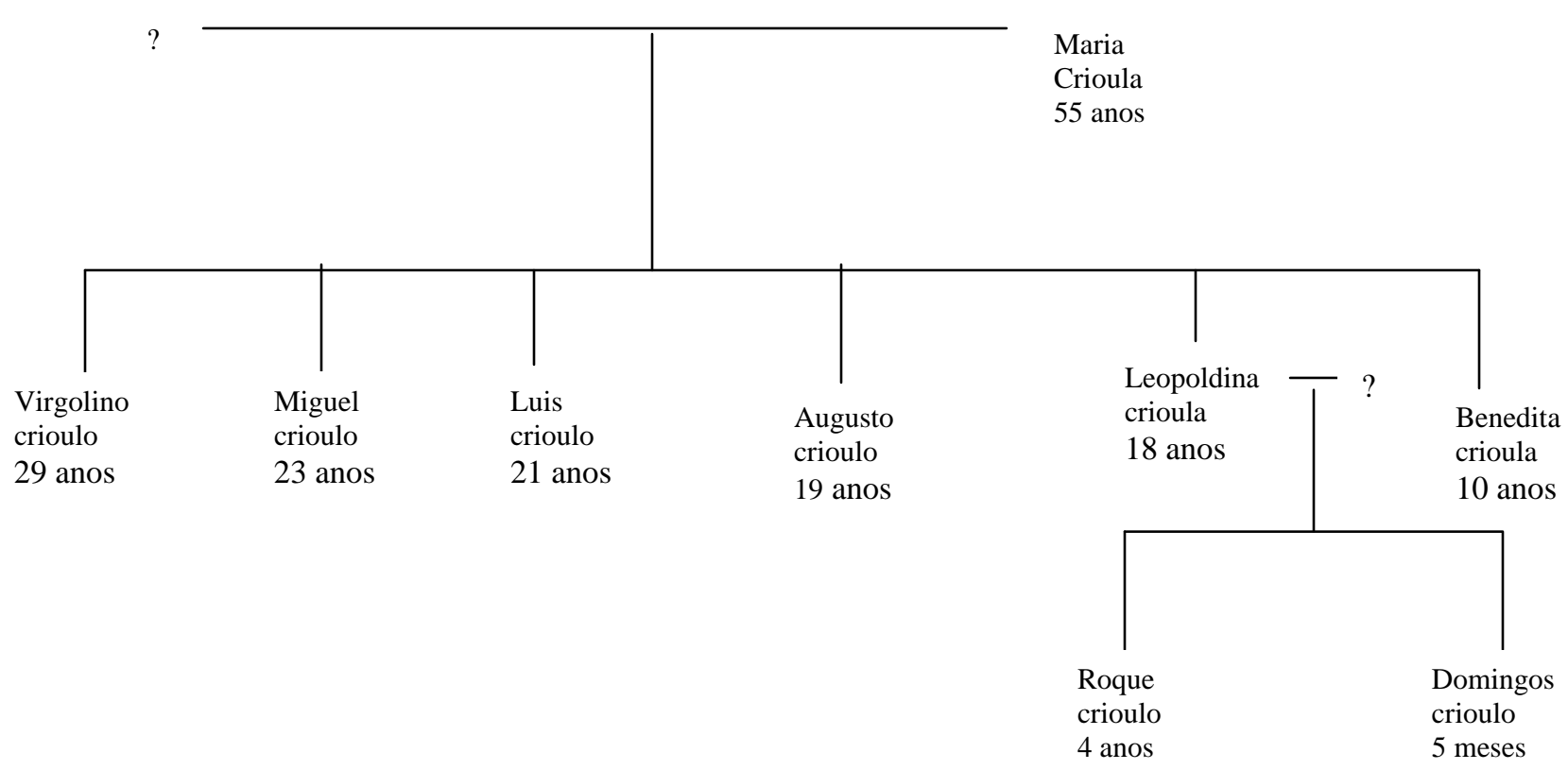

Devido à situação econômica da inventariante, todos os cativos foram levados à leilão para pagamento das dívidas passivas, maiores que o valor total dos bens do casal. Assim sendo, Maria ficou em companhia de cinco de seus filhos, enquanto Leopoldina e seus dois rebentos foram adquiridos por outra pessoa, Antônio Jordão da Silva Vargas.

Mesmo diante de casos de separações, os escravos experimentaram o sentimento de pertencimento a uma família. Um núcleo maior que aquele formado por mães, pais e filhos, incluindo avôs, avós, tios e sobrinhos que compartilharam memórias, lembranças e histórias que, certamente, eram contadas pelos mais velhos.

\footnotetext{
${ }^{187}$ Os pontos de interrogação correspondem aos parentes não localizados e as idades foram encontradas nos documentos.
} 
A preocupação com a memória familiar pode ser encontrada na família de Maria africana ${ }^{188}$. Esta escrava foi citada na matrícula de 1872, mas no ano de 1881, quando do inventário de seu proprietário, ela já havia morrido. Todavia, ela chegou a conviver com seus netos, embora não tenha conhecido seu bisneto.

\section{FIGURA 9}

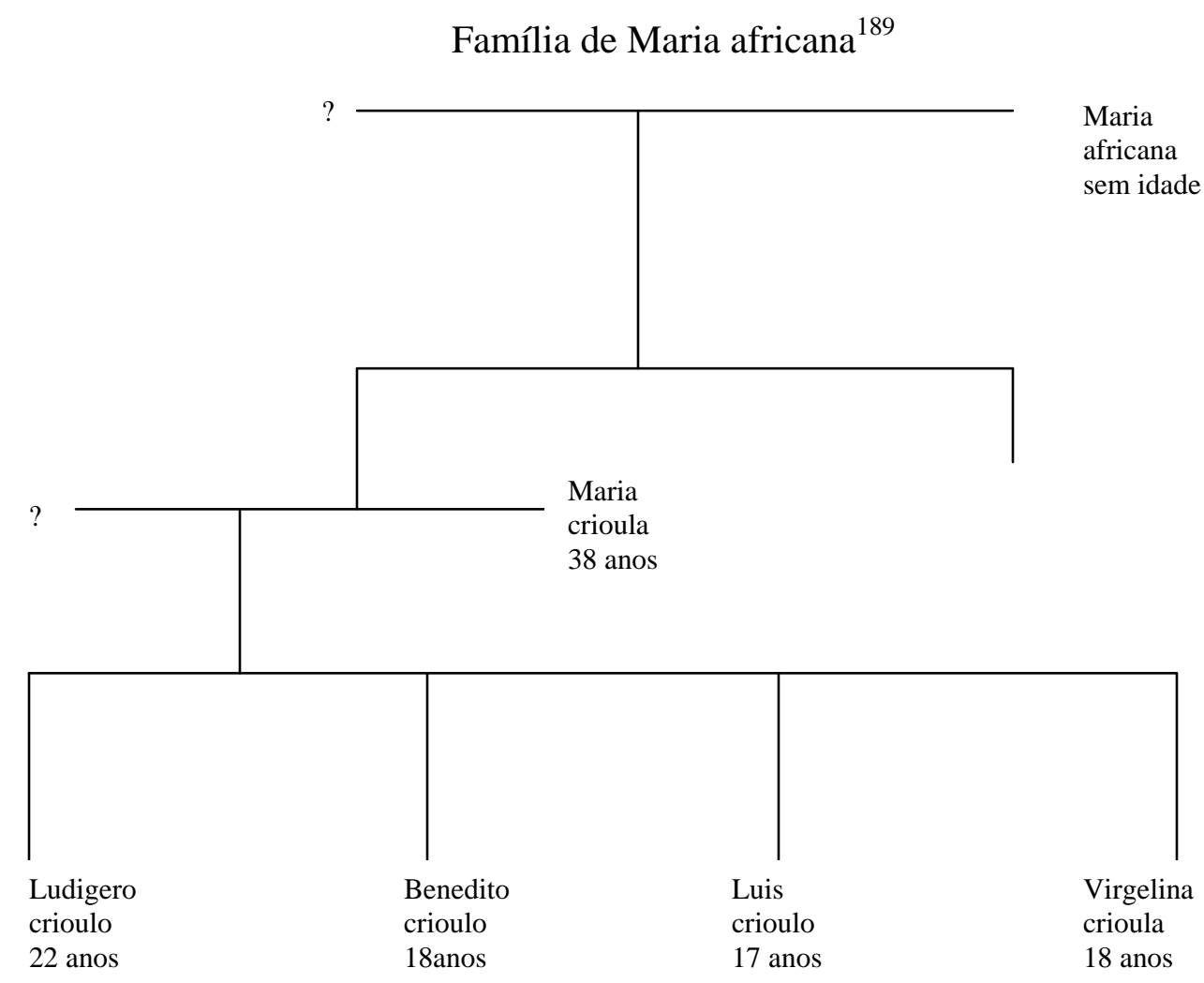


Maria africana tinha morrido em 1881, mas chegou a viver em companhia da filha, que recebeu o seu nome. Maria, a filha, foi avaliada com quatro filhos, sendo que Virgelina, de 18 anos, tinha parido um ingênuo, no ano de abertura do inventário.

Dos escravos mencionados na última família, Ludigero, Benedito e Luis não tiveram seus vínculos familiares citados no inventário. Não obstante, foram indicados como irmãos e filhos de Maria crioula, na matrícula de 1872. Ou seja, sem o cruzamento, os três irmãos seriam anotados como escravos que não participavam de laços parentais.

Eles foram alguns dos vários cativos cujas filiações não foram declaradas nos inventários. Isso significa que o percentual de 36,5\% de escravos em família, nos anos de 1800 até 1888, apontado no capítulo 4 é, tal como dissemos, um percentual mínimo, pois não inclui o compadrio e os trabalhadores pertencentes às famílias fraternas e extensas. Vamos, então, atualizar os dados? A tabela seguinte apresenta os números “novos”. 
TABELA 83

Freqüência de escravos envolvidos em famílias nucleares, matrifocais, fraternais e extensas por subperíodos e faixas de tamanho de propriedades. Angra dos Reis, 1800-1888

\begin{tabular}{|c|c|c|c|c|c|c|c|c|}
\hline FTP & $\begin{array}{c}1800-1815 \\
n^{\circ}(\%)\end{array}$ & $\begin{array}{c}1816-1826 \\
n^{\circ}(\%)\end{array}$ & $\begin{array}{c}1827-1837 \\
n^{\circ}(\%) \\
\end{array}$ & $\begin{array}{c}1838-1848 \\
n^{\circ}(\%) \\
\end{array}$ & $\begin{array}{c}1849-1859 \\
n^{\circ}(\%) \\
\end{array}$ & $\begin{array}{c}1860-1871 \\
\mathrm{n}^{\circ}(\%) \\
\end{array}$ & $\begin{array}{c}1872-1888 \\
n^{\circ}(\%)\end{array}$ & $\begin{array}{c}\text { Total } \\
\mathrm{n}^{\circ}(\%)\end{array}$ \\
\hline $\begin{array}{c}1-5 \\
\text { Escravos } \\
\text { com famílias }\end{array}$ & 0 & 0 & $10(26,3)$ & $6(12,0)$ & 3) & 8) & $12(22,2)$ & $59(18,7)$ \\
\hline $\begin{array}{l}\text { Escravos } \\
\text { sem famílias }\end{array}$ & $6(100,0)$ & $12(100,0)$ & $28(73,7)$ & $44(88,0)$ & $51(79,7)$ & $73(80,2)$ & $42(77,8)$ & $256(81,3)$ \\
\hline St & $6(100,0)$ & $12(100,0)$ & $38(100,0)$ & $50(100,0)$ & $64(100,0)$ & $91(100,0)$ & $54(100,0)$ & $315(100,0)$ \\
\hline $\begin{array}{c}\text { 6-10 } \\
\text { Escravos } \\
\text { com famílias }\end{array}$ & 0 & $2(14,3)$ & $10(25$ & $22(30,1)$ & $18(26,1)$ & $37(40,6)$ & $29(93,5)$ & $118(37,1)$ \\
\hline $\begin{array}{l}\text { Escravos } \\
\text { sem famílias }\end{array}$ & 0 & $12(85,7)$ & $30(75,0)$ & $51(69,9)$ & $51(73,9)$ & $54(59,4)$ & $2(6,5)$ & $200(62,9)$ \\
\hline St & 0 & $14(100,0)$ & $40(100,0)$ & $73(10$ & $69(100,0)$ & $91(100,0)$ & $31(100,0)$ & $318(100,0)$ \\
\hline $\begin{array}{c}11-20 \\
\text { Escravos } \\
\text { com famílias }\end{array}$ & $8(47,0)$ & 37 & 1. & ) & 7 & 81 & 71( & $230(49,9)$ \\
\hline $\begin{array}{l}\text { Escravos } \\
\text { sem famílias }\end{array}$ & $9(53,0)$ & $19(33,9)$ & $19(61,3)$ & $45(76,3)$ & $33(82,5)$ & $97(54,5)$ & $9(11,3)$ & $231(50,1)$ \\
\hline St & $17(100,0)$ & $56(100,0)$ & $31(100,0)$ & $59(100,0)$ & $40(100,0)$ & $178(100,0)$ & $80(100,0)$ & $461(100,0)$ \\
\hline $\begin{array}{l}21 \text { ou mais } \\
\text { Escravos } \\
\text { com famílias }\end{array}$ & 0 & $16(16,0)$ & $194(59,5)$ & $127(42,7)$ & $102(37,8)$ & $201(37,9)$ & $70(69,3)$ & $710(43,7)$ \\
\hline $\begin{array}{l}\text { Escravos } \\
\text { sem famílias }\end{array}$ & 0 & $84(84,0)$ & $132(40,5)$ & $170(57,2)$ & $168(62,2)$ & $329(62,1)$ & $31(30,7)$ & $914(56,3)$ \\
\hline St & 0 & $100(100,0)$ & $326(100,0)$ & $297(100,0)$ & $270(100,0)$ & $530(100,0)$ & $101(100,0)$ & $1.624(100,0)$ \\
\hline $\begin{array}{l}\text { Todas FTP } \\
\text { Escravos } \\
\text { com famílias }\end{array}$ & $8(34,8)$ & $55(30,2)$ & $26(52,0)$ & $169(35,3)$ & 31,6) & 37,8) & $182(68,4)$ & $1.117(41,1)$ \\
\hline $\begin{array}{c}\text { Escravos } \\
\text { sem famílias }\end{array}$ & $15(65,2)$ & $127(69,8)$ & $209(48,0)$ & $310(64,7)$ & $303(68,4)$ & $553(62,2)$ & $84(31,6)$ & $1.601(58,9)$ \\
\hline Total & $23(100)$, & $182(100,0)$ & $435(100,0)$ & $479(100,0)$ & $443(100,0)$ & $890(100,0)$ & $266(100,0)$ & $2.718(100,0)$ \\
\hline
\end{tabular}

FONTES: Inventários post-mortem de escravistas de Angra dos Reis, 1800-1888. Museu da Justiça do Estado do Rio de Janeiro, RJ. NOTA: St=subtotal.

Em Angra dos Reis, 41,1\% dos escravos conviviam com familiares como, mães, pais, irmãos, avós, etc. ${ }^{190}$. Nos anos de 1800 até 1848, 40,9\% dos cativos estavam aparentados; enquanto, entre 1849 e 1888, foram 41,2\%. O último percentual foi beneficiado pela localização das famílias fraternas e extensas.

Por faixa de tamanho de propriedade (FTP), a freqüência de escravos envolvidos em famílias foi maior nas propriedades médias e grandes. Este informe confirma idéia

190 Ainda assim, este percentual não corresponde aos escravos efetivamente aparentados, visto que o compadrio não está incluído. 
apresentada nos capítulos anteriores: de que a experiência familiar, em particular a legítima, era mais acessível aos cativos de senhores mais aquinhoados.

Por exemplo, na FTP de 1-5, a família foi uma realidade para 18,7\% dos escravos, em todo o período de estudo. Na FTP de 6-10, o percentual foi de 37,1\%; chegando a 49,9\% nas propriedades com 11 a 20 cativos; e 43,7\%, nas escravarias com 21 ou mais trabalhadores compulsórios. Nos anos de 1872 até 1888, a participação de escravos aparentados chegou a 93,5\%, na faixa de 6 a 10; 88,7\%, na FTP de 11-20; e 69,3\%, nas grandes propriedades. Portanto, as famílias escravas de Angra não se resumiram às nucleares e matrifocais.

Por certo, a família extensa foi local beneficiado para a transmissão de uma memória geracional. Vimos isso no caso da família da escrava Maria africana, cuja filha recebera seu nome. Encontramos em outro trabalho (VASCONCELLOS, 2002, p.112), sobre a freguesia de Mambucaba, uma situação semelhante: Manoel Jordão da Silva $\operatorname{Vargas}^{191}$, no inventário datado de 1862, tinha em sua propriedade um escravo de nome José africano da Guiné. Ele havia ficado viúvo de Vitória, também africana. O casal teve quatro filhos, sendo que uma das filhas, de nome Francisca, pariu três vezes: Cândido, nascido em 1856, Vitória, nascida em 1858, e Serafina, nascida em 1860. A segunda criança recebeu o nome de sua falecida avó. Seria coincidência? Na ocasião em que trabalhamos com aquela família havíamos considerado que não. O que de fato ocorreu foi a preocupação em manter na memória da família, a lembrança da mais antiga genitora, Vitória africana (VASCONCELLOS, 2002, p.113-114). Florentino \& Góes encontraram a mesma preocupação, em Campo Grande, no Rio de Janeiro, na primeira metade do século XIX (FLORENTINO \& GÓES, 1997, p. 82).

No próximo, e último capítulo, veremos como os parentes foram tratados no momento da partilha.

\footnotetext{
${ }^{191}$ Inventário de Manoel Jordão da Silva Vargas, 1862. Angra dos Reis, RJ. Museu da Justiça do Estado do Rio de Janeiro, RJ. No presente trabalho de doutoramento também analisamos esse inventário.
} 


\section{CAPÍTULO 12-OS LAÇOS PARENTAIS NO MOMENTO DA PARTILHA DOS BENS}

O momento de partilha dos bens de um proprietário era esperado entre os herdeiros, entre os credores, quando havia e, principalmente, entre os escravos. Os últimos, possivelmente, ficavam na expectativa de saber quem seria seus novos donos, em particular quando estavam envolvidos em famílias.

A fim de verificar o destino dado aos grupos parentais, dividimos a análise entre famílias nucleares, matrifocais, fraternas e extensas.

Independentemente do tipo de família, entre 1800 e 1888, 33,6\% dos grupos parentais foram separados, ou melhor, tiveram alguns de seus membros afastados dos demais. Quando isso ocorria, geralmente envolvia mães e filhos com mais de 10 anos, quando já estavam em idade produtiva, ou irmãos, ou mães, filhas e netas. No entanto, $66,4 \%$ das famílias permaneceram unidas.

O último percentual é um indício de que os herdeiros respeitaram e se preocuparam com a manutenção dos grupos parentais. Isso resultou de uma conscientização entre os livres sobre a importância da instituição familiar para os escravos. Tratava-se, ao nosso ver, de uma conquista assegurada pelos cativos ${ }^{192}$.

Não contamos com exemplos de escravos que "lutaram" por manter-se unidos; contudo encontramos em um inventário a história de uma batalha travada na justiça por escravos e seus parentes, tentando garantir seus direitos. Isto é, os escravos tiveram a capacidade, e o espaço, para fazer valer seus interesses. Vejamos o caso:

No inventário de Luiza Maria dos Anjos, de $1862^{193}$, houve uma tentativa, da parte dos herdeiros, de incluir no espólio da falecida, dois alforriados. Rita crioula, de 35 anos, e seu filho Zacarias, de 15 anos, chegaram a ser avaliados e seriam recebidos em herança.

\footnotetext{
192 Quantas famílias não foram separadas até que o "direito” à manutenção dos laços no momento da partilha tenha sido garantido aos cativos? Quantos não foram os escravos que se opuseram a uma separação forçada?

${ }^{193}$ Inventário de Luiza Maria dos Anjos, 1862. Angra dos Reis, RJ. Museu da Justiça do Estado do Rio de Janeiro, RJ.
} 
Luiza Maria dos Anjos havia alforriado em testamento sete escravos, não constando o nome dos suplicantes. No entanto, Rita e seu filho moveram uma ação contra os herdeiros, na qual afirmavam que viviam à anos na casa de Josefa, alforriada no testamento da inventariada. Diziam, também, que eram reconhecidos por todos como livres. Josefa era mãe de Rita e, portanto, avó de Zacarias.

O testamenteiro, e também herdeiro, tentou de todas as formas garantir a posse dos dois; no entanto, o juiz considerou procedente o argumento dos suplicantes, principalmente, depois da apresentação das duas cartas de alforria, que estavam guardadas na casa de outro forro. Nas cartas constavam que, após a morte da inventariada, Rita e Zacarias estariam libertos.

A história nos chamou a atenção em primeiro lugar, pela tentativa de se reescravizar alforriados, fato que, possivelmente, deve ter sido corriqueiro; em segundo, porque mostrou a cumplicidade entre pessoas que haviam passado pelo cativeiro e os escravos; e, por último, a permanência de contato entre familiares, mesmo estando alguns forros e os outros escravizados, ou forros condicionalmente.

Consideramos pertinente contar, também, a história de Joaquim africano do Congo, forro, de sua esposa, a escrava Isabel africana também do Congo, e de seus três filhos.

No inventário de Bernardo Vigário Manuel Pinto Pimentel, de 1835, morador na Ilha da Gipóia, na freguesia da Conceição, constavam 19 escravos $^{194}$. Dentre eles estavam Isabel e seus três filhos. Eles foram avaliados e chegaram a ser distribuídos entre os herdeiros. Entretanto, Joaquim, já como forro, apresentou os valores relativos a sua esposa e aos dois filhos, um de 12 anos e outro com um ano e meio de idade. Ele não encontrou problemas em adquirir as cartas de alforria dos três. Por certo, ele dedicou-se muito até conseguir a quantia necessária a fim de libertar sua esposa e filhos. Mas, uma filha de 11 anos continuou como escrava.

Estaria aquela família separada pelo cativeiro? Possivelmente, não. E não duvidamos que Joaquim tenha tentado, posteriormente, comprar a carta de alforria de sua filha.

${ }^{194}$ Inventário de Bernardo Vigário Manuel Pinto Pimentel, 1835. Angra dos Reis, RJ. Museu da Justiçado Estado do Rio de Janeiro, RJ. 
A família de Joaquim é tanto um exemplo de perseverança e dedicação pela busca da liberdade, quanto, infelizmente, um exemplo de separação. Entretanto, mesmo esta “separação” deve ser relativizada, pois, possivelmente, o casal manteve-se próximo à filha ainda escrava.

É com esse cuidado que devemos observar os dados seguintes. Entendemos como separação os casos em que ocorreu, ao menos, o afastamento de um ente querido. No entanto, esse distanciamento deve ser colocado entre aspas pois os herdeiros poderiam ser vizinhos, o que, na prática, não significava separação efetiva.

Feitas as observações, passemos à análise da tabela.

\section{TABELA 84}

Freqüência de separação de famílias nucleares e de seus parentes na partilha, por subperíodos.

Angra dos Reis, 1800-1888

\begin{tabular}{cccccccc|c|c}
\hline Famílias & $\begin{array}{c}1800-1815 \\
\mathrm{n}^{\mathrm{o}}(\%)\end{array}$ & $\begin{array}{c}1816-1826 \\
\mathrm{n}^{\mathrm{o}}(\%)\end{array}$ & $\begin{array}{c}1827-1837 \\
\mathrm{n}^{\mathrm{o}}(\%)\end{array}$ & $\begin{array}{c}1838-1848 \\
\mathrm{n}^{\circ}(\%)\end{array}$ & $\begin{array}{c}1849-1859 \\
\mathrm{n}^{\circ}(\%)\end{array}$ & $\begin{array}{c}1860-1871 \\
\mathrm{n}^{\mathrm{o}}(\%)\end{array}$ & $\begin{array}{c}1872-1888 \\
\mathrm{n}^{\circ}(\%)\end{array}$ & $\begin{array}{c}\text { Total } \\
\mathrm{n}^{\circ}(\%)\end{array}$ \\
\hline $\begin{array}{c}\text { Famílias } \\
\text { separadas }\end{array}$ & 0 & 0 & $5(17,2)$ & $6(54,5)$ & $6(46,2)$ & $5(41,7)$ & $2(100,0)$ & $24(32,8)$ \\
$\begin{array}{c}\text { Famílias não } \\
\text { separadas }\end{array}$ & $2(100,0)$ & $4(100,0)$ & $24(82,8)$ & $5(45,5)$ & $7(53,8)$ & $7(58,3)$ & 0 & $49(67,1)$ \\
Total de FN & $2(100,0)$ & $4(100,0)$ & $29(100,0)$ & $11(100,0)$ & $13(100,0)$ & $12(100,0)$ & $2(100,0)$ & $73(100,0)$ \\
\hline $\begin{array}{c}\text { Parentes } \\
\text { separados }\end{array}$ & 0 & 0 & $26(27,7)$ & $24(58,5)$ & $20(50,0)$ & $15(39,5)$ & $7(100,0)$ & $92(37,8)$ \\
$\begin{array}{c}\text { Parentes não } \\
\text { separados } \\
\text { Total de }\end{array}$ & $8(100,0)$ & $15(100,0)$ & $68(72,3)$ & $17(41,5)$ & $20(50,0)$ & $23(60,5)$ & 0 & $151(62,1)$ \\
$\begin{array}{c}\text { parentes de } \\
\text { FN }\end{array}$ & $8(100,0)$ & $15(100,0)$ & $94(100,0)$ & $41(100,0)$ & $40(100,0)$ & $38(100,0)$ & $7(100,0)$ & $243(100,0)$ \\
\hline
\end{tabular}

FONTES: Inventários post-mortem de escravistas de Angra dos Reis, 1800-1888. Museu da Justiça do Estado do Rio de Janeiro, RJ.

NOTAS: FN=famílias nucleares. Em três inventários não havia informações acerca da partilha, somando três famílias nucleares.

Das famílias nucleares localizadas entre 1800 e 1888, 67,1\% continuaram unidas após a partilha, representando 62,1\% dos parentes. Entre 1800 e 1848, 76,1\% dos grupos parentais legítimos foram preservados; e, entre 1849 e 1888, 51,9\%.

A tendência à preservação das famílias nucleares foram observadas também por Florentino \& Góes (1997, p.118-119), no agro fluminense, entre 1790 e 1830. Afirmaram, inclusive, que “a sanção legal-religiosa protegia mais os parentes escravos embora, não importando o tipo de arranjo parental, fosse sempre maior a tendência à não pulverização familiar quando da morte dos senhores”. 
Em geral, houve a manutenção dos laços entre os escravos que participavam daquele tipo de família, em Angra dos Reis. Mas a queda percentual verificada para a segunda metade do século chamou nossa atenção. Será que o contexto da segunda metade do século XIX influenciou uma mudança de comportamento dos herdeiros quanto às famílias escravas?

Examinemos o destino dado às famílias matrifocais e, depois, voltaremos à pergunta.

TABELA 85

Freqüência de separação de famílias matrifocais e de seus parentes na partilha, por subperíodos. Angra dos Reis, 1800-1888

\begin{tabular}{|c|c|c|c|c|c|c|c|c|}
\hline Famílias & $\begin{array}{c}1800-1815 \\
n^{\circ}(\%)\end{array}$ & $\begin{array}{c}1816-1826 \\
n^{\circ}(\%)\end{array}$ & $\begin{array}{c}1827-1837 \\
\mathrm{n}^{\circ}(\%)\end{array}$ & $\begin{array}{c}1838-1848 \\
n^{\circ}(\%)\end{array}$ & $\begin{array}{c}1849-1859 \\
n^{\circ}(\%)\end{array}$ & $\begin{array}{c}1860-1871 \\
n^{\circ}(\%)\end{array}$ & $\begin{array}{c}1872-1888 \\
n^{\circ}(\%)\end{array}$ & $\begin{array}{c}\text { Total } \\
\mathrm{n}^{\circ}(\%)\end{array}$ \\
\hline $\begin{array}{l}\text { Famílias } \\
\text { separadas }\end{array}$ & 0 & $2(16,7)$ & $15(45,4)$ & $10(26,3)$ & $12(33,3)$ & $18(23,1)$ & $8(40,0)$ & $65(30,0)$ \\
\hline $\begin{array}{c}\text { Famílias não } \\
\text { separadas }\end{array}$ & 0 & $10(83,3)$ & $18(54,5)$ & $28(73,7)$ & $24(66,7)$ & $60(76,9)$ & $12(60,0)$ & $152(70,0)$ \\
\hline Total de FM & 0 & $12(100,0)$ & $33(100,0)$ & $38(100,0)$ & $36(100,0)$ & $78(100,0)$ & $20(100,0)$ & $217(100,0)$ \\
\hline $\begin{array}{l}\text { Parentes } \\
\text { separados }\end{array}$ & 0 & $2(5,3)$ & $59(53,6)$ & $35(29,9)$ & $36(37,1)$ & $59(25,9)$ & $24(32,0)$ & $215(32,3)$ \\
\hline $\begin{array}{c}\text { Parentes não } \\
\text { separados }\end{array}$ & 0 & $36(94,7)$ & $51(46,4)$ & $82(70,1)$ & $61(62,9)$ & $169(74,1)$ & $51(68,0)$ & $450(67,7)$ \\
\hline $\begin{array}{c}\text { Total de } \\
\text { parentes de } \\
\text { FM }\end{array}$ & 0 & $38(100,0)$ & $110(100,0)$ & $117(100,0)$ & $97(100,0)$ & $228(100,0)$ & $75(100,0)$ & $665(100,0)$ \\
\hline
\end{tabular}

FONTES: Inventários post-mortem de escravistas de Angra dos Reis, 1800-1888. Museu da Justiça do Estado do Rio de Janeiro, RJ.

NOTAS: FM=famílias matrifocais. Para trinta e seis famílias não havia informações acerca da partilha.

Entre 1800 e 1888, 70,0\% das famílias matrifocais continuaram juntas após a partilha. No intervalo de 1800-1848, 67,5\% e, de 1849 a 1888, o percentual chegou a 71,6\%. Portanto, a freqüência de manutenção dos ditos grupos parentais aumentou, ao longo dos anos.

Observamos, comparando os informes localizados para os dois tipos de famílias, que, na primeira metade do século, 68,4\% dos parentes pertencentes às famílias legitimadas continuaram juntos. Percentual semelhante foi encontrado entre os membros das matrifocais, 67,5\%. Havia, em geral, um comprometimento com a manutenção dos laços parentais entre os escravos. 
Na segunda metade dos oitocentos, 51,9\% dos escravos que faziam parte de famílias legítimas continuaram juntos após a partilha. Entre os membros que pertenciam às matrifocais, 71,6\% foram mantidos unidos.

A discrepância entre os percentuais calculados para os escravos do primeiro tipo de família e os do segundo chama a atenção. Impressiona principalmente a queda do percentual entre os parentes legitimados.

Pelo que parece, as famílias nucleares, após 1850, ficaram mais vulneráveis às separações. No entanto, o tipo de separação ${ }^{195}$ ocorrido entre os participantes dos grupos não legitimados e os formados a partir do casamento foi diferente.

\section{TABELA 86}

Tipo de separações ocorridas entre as famílias nucleares na partilha, por faixa de tamanho de propriedades e por subperíodos. Angra dos Reis, 1800-1888

\begin{tabular}{|c|c|c|c|}
\hline FTP & $\begin{array}{c}1800-1848 \\
\mathrm{n}^{\circ}(\%)\end{array}$ & $\begin{array}{c}1849-1888 \\
n^{\circ}(\%)\end{array}$ & $\begin{array}{c}1800-1888 \\
n^{\circ}(\%)\end{array}$ \\
\hline \multicolumn{4}{|l|}{$1-5$} \\
\hline Separação parcial & 0 & 0 & 0 \\
\hline Separação total & 0 & 0 & 0 \\
\hline Total de separações & 0 & 0 & 0 \\
\hline \multicolumn{4}{|l|}{$6-10$} \\
\hline Separação parcial & 0 & $1(100,0)$ & $1(100,0)$ \\
\hline Separação total & 0 & 0 & 0 \\
\hline Total de separações & 0 & $1(100,0)$ & $1(100,0)$ \\
\hline \multicolumn{4}{|l|}{$11-20$} \\
\hline Separação parcial & $1(100,0)$ & $3(75,0)$ & $4(80,0)$ \\
\hline Separação total & 0 & $1(25,0)$ & $1(20,0)$ \\
\hline Total de separações & $1(100,0)$ & $4(100,0)$ & $5(100,0)$ \\
\hline \multicolumn{4}{|l|}{21 ou mais } \\
\hline Separação parcial & $9(90,0)$ & $6(75,0)$ & $15(83,3)$ \\
\hline Separação total & $1(10,0)$ & $2(25,0)$ & $3(16,7)$ \\
\hline Total de separações & $10(100,0)$ & $8(100,0)$ & $18(100,0)$ \\
\hline \multicolumn{4}{|l|}{ Todas as FTP } \\
\hline Separação parcial & $10(90,9)$ & $10(76,9)$ & $20(83,3)$ \\
\hline Separação total & $1(9,1)$ & $3(23,1)$ & $4(16,7)$ \\
\hline Total de separações & $11(100,0)$ & $13(100,0)$ & $24(100,0)$ \\
\hline
\end{tabular}

FONTES: Inventários post-mortem de escravistas de Angra dos Reis, 1800-1888. Museu da Justiça do Estado do Rio de Janeiro, RJ.

Entre as famílias nucleares separadas durante a partilha, nos anos de 1800 até 1848, houve uma separação parcial, envolvendo uma família que vivia na FTP de 11-20; na FTP de 21 ou mais escravos, encontramos nove grupos familiares com separação

\footnotetext{
${ }^{195}$ Classificamos as separações em "separações parciais", quando houve o desmembramento de um ou dois familiares e "separações totais", quando o grupo familiar foi totalmente dividido entre os herdeiros.
} 
parcial e uma família onde todos foram separados. No total, das 11 famílias separadas, 10 $(90,1 \%)$ tiveram alguns dos membros afastados. Esse tipo de separação caracterizou-se pelo envio do casal para um mesmo herdeiro e um ou dois filhos, quase sempre os mais velhos, para outros herdeiros.

No caso das famílias matrifocais, entre 1800 e 1848, localizamos, na FTP de 1-5, duas famílias separadas totalmente; na FTP de 6-10, duas separadas parcialmente e uma, total; na FTP de 11-20, foram dois grupos familiares com separação parcial e dois, com separação total; na FTP de 21 ou mais escravos, oito grupos tiveram separação de um dos membros, e 10 famílias das quais todos os parentes foram separados. Portanto, das 27 famílias que tiveram seus membros afastados, 15 (55,5\%) grupos foram totalmente separados, contra 12 (44,4\%) com separação parcial.

\section{TABELA 87}

Tipo de separações ocorridas entre as famílias matrifocais na partilha, por faixa de tamanho de propriedades e por subperíodos. Angra dos Reis, 1800-1888

\begin{tabular}{ccccc}
\hline FTP & $\begin{array}{c}1800-1848 \\
\mathrm{n}^{\circ}(\%)\end{array}$ & $\begin{array}{c}1849-1888 \\
\mathrm{n}^{\circ}(\%)\end{array}$ & $\begin{array}{c}1800-1888 \\
\mathrm{~N}(\%)\end{array}$ \\
\hline $1-5$ & & $2(50,0)$ & $2(33,3)$ \\
Separação parcial & 0 & $2(50,0)$ & $4(66,7)$ \\
Separação total & $2(100,0)$ & $6(100,0)$ \\
Total de separações & $2(100,0)$ & $4(100,0)$ & 6 \\
\hline $6-10$ & & & \\
Separação parcial & $2(66,7)$ & $7(70,0)$ & $9(69,2)$ \\
Separação total & $1(33,3)$ & $3(30,0)$ & $4(30,8)$ \\
Total de separações & $3(100,0)$ & $10(100,0)$ & $13(100,0)$ \\
\hline 11-20 & & & \\
Separação parcial & $2(50,0)$ & $2(28,6)$ & $4(36,4)$ \\
Separação total & $2(50,0)$ & $5(71,4)$ & $7(63,6)$ \\
Total de separações & $4(100,0)$ & $7(100,0)$ & $11(100,0)$ \\
\hline 21 ou mais & & & \\
Separação parcial & $8(44,4)$ & $8(47,1)$ & $16(45,7)$ \\
Separação total & $10(55,6)$ & $9(52,9)$ & $19(54,3)$ \\
Total de separações & $18(100,0)$ & $17(100,0)$ & $35(100,0)$ \\
\hline Todas as FTP & & & \\
Separação parcial & $12(44,4)$ & $19(50,0)$ & $31(47,7)$ \\
Separação total & $15(55,5)$ & $19(50,0)$ & $34(52,3)$ \\
Total de separações & $27(100,0)$ & $38(100,0)$ & $65(100,0)$ \\
\hline
\end{tabular}

FONTES: Inventários post-mortem de escravistas de Angra dos Reis, 1800-1888. Museu da Justiça do Estado do Rio de Janeiro, RJ.

Portanto, as famílias matrifocais foram mais atingidas com a separação total, do que as nucleares. Ou seja, a legitimidade garantia, em parte, maior estabilidade aos núcleos parentais. 
Dentre as famílias nucleares, nos anos de 1849 e 1888, vimos que: na FTP de 6-10, um casal, no momento da partilha, continuou junto, mas foi separado do filho; na FTP de 11-20, houve três separações parciais e uma separação total; na FTP de 21 ou mais, encontramos seis grupos nos quais houve separação parcial, e duas famílias com separação total. Totalizando, na segunda metade do século XIX, das 13 famílias nucleares que foram separadas na partilha, 10 (76,9\%) foram afastadas parcialmente, sendo que nove casais foram encaminhados para o mesmo herdeiro, porém seus filhos foram recebidos por outros. Enquanto isso, três $(23,1 \%)$ grupos parentais foram totalmente desmembrados. Ou seja, as separações, geralmente, foram parciais.

Entre 1800 e 1888, as famílias nucleares foram mais preservadas que as matrifocais, durante a partilha dos bens. Todavia, na segunda metade dos oitocentos, a freqüência das primeiras diminuiu, mas, geralmente, a separação atingiu apenas um ou dois membros.

No caso das famílias matrifocais, entre 1849 e 1888, localizamos: na FTP 1-5, duas famílias afastadas parcialmente e duas, totalmente desmembradas; na FTP de 6-10, sete grupos parentais tiveram separação parcial e três, total; na FTP de 11-20, foram, respectivamente, duas e cinco famílias; na FTP de 21 ou mais cativos, oito famílias tiveram separação parcial e nove, separação total. No somatório 19 (50,0\%) e 19 (50,0\%), respectivamente, grupos parentais foram afastadas parcial e totalmente.

Confrontando os informes para os anos anteriores a 1850 e posteriores, no caso das matrifocais, 44,4\% tiveram um dos membros separados, entre 1800 e 1848, e 50,0\%, após 1849. Enfim, entre as famílias caracterizadas pela ilegitimidade, a separação total foi mais comum antes de 1850 e, depois equiparou-se às parciais.

Entre 1800-1888, 16,7\% das nucleares tiveram separações totais, enquanto em $52,3 \%$ das matrifocais, todos os membros se separaram ${ }^{196}$. Em geral, a legitimidade garantiu a permanência de um número de parentes.

Equiparando-se as freqüências de separações parciais entre as nucleares e as matrifocais, as primeiras foram mais beneficiadas. Isso foi verdade independentemente do recorte temporal.

${ }^{196}$ Cálculo realizado sobre as famílias desmembradas. 
Em geral, as famílias foram preservadas. E quando houve separação, predominaram as parciais.

As famílias fraternas também foram, freqüentemente, preservadas. Contudo, a incidência de separações foi maior nestas do que nas nucleares e nas matrifocais.

TABELA 88

Freqüência de separação de famílias fraternas e de seus parentes na partilha, por subperíodos. Angra dos Reis, 1800-1888

\begin{tabular}{|c|c|c|c|c|c|c|c|c|}
\hline Famílias & $\begin{array}{c}1800-1815 \\
n^{\circ}(\%)\end{array}$ & $\begin{array}{c}1816-1826 \\
n^{\circ}(\%)\end{array}$ & $\begin{array}{c}1827-1837 \\
\mathrm{n}^{\circ}(\%)\end{array}$ & $\begin{array}{c}1838-1848 \\
n^{\circ}(\%)\end{array}$ & $\begin{array}{c}1849-1859 \\
\mathrm{n}^{\circ}(\%)\end{array}$ & $\begin{array}{c}1860-1871 \\
\mathrm{n}^{\circ}(\%)\end{array}$ & $\begin{array}{c}1872-1888 \\
\mathrm{n}^{\circ}(\%)\end{array}$ & $\begin{array}{c}\text { Total } \\
\mathrm{n}^{\circ}(\%)\end{array}$ \\
\hline FF separadas & 0 & 0 & 0 & 0 & $1(100,0)$ & $4(80,0)$ & $3(27,3)$ & $8(44,4)$ \\
\hline $\begin{array}{c}\text { FF não } \\
\text { separadas }\end{array}$ & 0 & 0 & $1(100,0)$ & 0 & 0 & $1(20,0)$ & $8(73,7)$ & $10(55,6)$ \\
\hline Total de FF & 0 & 0 & $1(100,0)$ & 0 & $1(100,0)$ & $5(100,0)$ & $11(100,0)$ & $18(100,0)$ \\
\hline $\begin{array}{l}\text { Parentes } \\
\text { separados }\end{array}$ & 0 & 0 & 0 & 0 & $3(100,0)$ & $16(88,9)$ & $10(25,6)$ & $29(46,8)$ \\
\hline $\begin{array}{l}\text { Parentes não } \\
\text { separados }\end{array}$ & 0 & 0 & $2(100,0)$ & 0 & 0 & $2(11,1)$ & $29(74,4)$ & $33(53,2)$ \\
\hline $\begin{array}{c}\text { Total de } \\
\text { parentes de } \\
\text { FF }\end{array}$ & 0 & 0 & $2(100,0)$ & 0 & $3(100,0)$ & $18(100,0)$ & $39(100,0)$ & $62(100,0)$ \\
\hline
\end{tabular}

FONTES: Inventários post-mortem de escravistas de Angra dos Reis, 1800-1888. Museu da Justiça do Estado do Rio de Janeiro, RJ.

NOTA: FF=famílias fraternas.

Quase todas as famílias extensas, ao contrário das anteriores, foram separadas durante a partilha. Mas, também entre elas, as separações parciais foram mais comuns, garantindo a permanência, freqüentemente, dos laços entre mães e filhos, e afastamento de avôs e netos, tios e sobrinhos. 
TABELA 89

Freqüência de separação de famílias extensas e de seus parentes na partilha, por subperíodos. Angra dos Reis, 1800-1888

\begin{tabular}{|c|c|c|c|c|c|c|c|c|}
\hline Famílias & $\begin{array}{c}1800-1815 \\
\mathrm{n}^{\circ}(\%)\end{array}$ & $\begin{array}{c}1816-1826 \\
\mathrm{n}^{\circ}(\%)\end{array}$ & $\begin{array}{c}1827-1837 \\
\mathrm{n}^{\circ}(\%)\end{array}$ & $\begin{array}{c}1838-1848 \\
\mathrm{n}^{\circ}(\%)\end{array}$ & $\begin{array}{c}1849-1859 \\
\mathrm{n}^{\circ}(\%)\end{array}$ & $\begin{array}{c}1860-1871 \\
\mathrm{n}^{\circ}(\%)\end{array}$ & $\begin{array}{c}1872-1888 \\
\mathrm{n}^{\circ}(\%)\end{array}$ & $\begin{array}{c}\text { Total } \\
\mathrm{n}^{\circ}(\%)\end{array}$ \\
\hline FE separadas & 0 & 0 & $2(100,0)$ & $1(100,0)$ & 0 & $4(100,0)$ & $2(66,6)$ & $9(90,0)$ \\
\hline $\begin{array}{c}\text { FE não } \\
\text { separadas }\end{array}$ & 0 & 0 & 0 & 0 & 0 & 0 & $1(33,4)$ & $1(10,0)$ \\
\hline Total de FE & 0 & 0 & $2(100,0)$ & $1(100,0)$ & 0 & $4(100,0)$ & $3(100,0)$ & $10(100,0)$ \\
\hline $\begin{array}{l}\text { Parentes } \\
\text { separados }\end{array}$ & 0 & 0 & $13(100,0)$ & $3(100,0)$ & 0 & $27(100,0)$ & $22(75,9)$ & $65(90,3)$ \\
\hline $\begin{array}{l}\text { Parentes não } \\
\text { separados }\end{array}$ & 0 & 0 & 0 & 0 & 0 & 0 & $7(24,1)$ & $7(9,7)$ \\
\hline $\begin{array}{c}\text { Total de } \\
\text { parentes de } \\
\text { FE }\end{array}$ & 0 & 0 & $13(100,0)$ & $3(100,0)$ & 0 & $27(100,0)$ & $29(100,0)$ & $72(100,0)$ \\
\hline
\end{tabular}

FONTES: Inventários post-mortem de escravistas de Angra dos Reis, 1800-1888. Museu da Justiça do Estado do Rio de Janeiro, RJ.

NOTAS: FE=famílias extensas. Em inventários abertos entre os anos de 1872 e 1888 encontramos três famílias extensas. No entanto, não havia informações acerca da partilha, impossibilitando a inclusão da mesma na tabela e de seus 10 parentes, o mesmo acontecendo com uma família, e seus três membros, localizada entre os anos de 1827 e 1837.

A maior parte das famílias, excluindo as extensas, continuaram juntas após a partilha dos bens de seus proprietários. Isso foi mais comum entre as nucleares, na primeira metade do século e, entre as matrifocais, na segunda parte dos oitocentos.

Portanto, entre 1800 e 1888, em geral, houve a preservação dos grupos parentais. Este comportamento, ao que parece, foi comum às demais regiões. A afirmação seguinte foi feita para o agro fluminense:

“Três entre cada quatro famílias escravas certamente permaneceram unidas após a partilha entre os herdeiros, cifra que aumenta para quatro em cada grupo de cinco, considerando-se as famílias cujos destinos eram dados a conhecer pela fonte” (FLORENTINO \& GÓES, 1997, p. 116).

Entretanto, observando as separações ocorridas, concluímos que, de 1800 até 1848, as famílias nucleares foram menos atingidas, se comparadas às matrifocais. Mesmo havendo afastamento de parentes, predominavam as separações parciais. Já nas matrifocais, as separações totais foram mais comuns. O único grupo parental fraterno 
localizado naqueles anos também foi preservado, diferentemente do que ocorreu com as três famílias extensas.

Por conseguinte, num quadro econômico e demográfico mais "favorável", os herdeiros tenderam a respeitar os laços parentais de seus escravos.

Entre 1849 e 1888, o percentual de famílias legitimadas que foram atingidas pela separação aumentou ${ }^{197}$, acompanhado pela elevação numérica de mais duas famílias totalmente separadas, contra apenas uma, nos anos de 1800 até 1848. A freqüência de afastamento de membros de grupos matrifocais diminuiu, assim como equiparou-se a incidência de separações parciais e totais. As oito famílias fraternas foram divididas entre os herdeiros e as sete extensas, também. Ou seja, após 1849, embora a tendência geral fosse a da manutenção dos grupos familiares, as nucleares sofreram com a queda de sua "estabilidade", comparando-se os percentuais para os dois subperíodos (1800-1848 e 1849-1888).

Mesmo diante destas variações, a família escrava passou bem pelo momento da partilha. Isso significa que os grupos parentais, entendidos como a célula da comunidade escrava, eram preservados. Assim, a comunidade conseguiu perpetuar-se no tempo, à revelia das transformações ocorridas na localidade após 1850.

${ }^{197}$ Embora a maior parte daquelas famílias tenham sido respeitadas durante a distribuição dos bens. 


\section{CONCLUSÃO}

O presente estudo buscou oferecer uma pequena contribuição à produção do conhecimento sobre a escravidão e a história do litoral sul-fluminense.

A história de Angra dos Reis, no século XIX, caracterizou-se por dois momentos: a primeira metade do século XIX, definida como um momento propício à economia local, com importante atividade portuária, plantações de café e produção da aguardente; a segunda metade, quando ocorreram diminuição do movimento portuário e o fim do tráfico de escravo, caracterizada por uma crise econômica - neste momento houve a diminuição da população escrava, de africanos, de aumento da participação de crioulos e de equilíbrio entre os sexos.

Ao menos uma parcela daqueles escravistas estava conseguindo se manter enquanto tal, visto que, entre os poucos cativos existentes em 1872, a maior parte era formada por adultos, seguida pelos idosos e por crianças. Estas últimas, por sua vez, apresentaram percentuais em torno de 28\%, deixando implícita a existência da reprodução natural, nascimentos que se beneficiaram da diminuição da diferença numérica entre homens e mulheres, por exemplo.

Neste contexto, a freqüência de famílias legitimadas pelo casamento diminuiu, movimento acompanhado pelo aumento das famílias formadas por mães solteiras. Isto ocorreu em função da intervenção dos senhores, temerosos com o risco da interferência da Igreja nas suas relações com seus cativos. Buscavam evitar a interseção daquela instituição, caso fosse necessário vender um dos cônjuges separadamente, prática censurada. A intromissão senhorial se ampliou a outros aspectos da vida de seus escravos, como a delimitação do local, da coletividade e da hora das cerimônias matrimoniais e, principalmente, na proibição de casamentos entre escravos de diferentes donos.

A participação daquelas famílias diminuiu na localidade também porque o decréscimo do número de escravos, intenso entre 1856 e 1872, significou a diminuição do número de cativos nas propriedades, reduzindo a oferta de possíveis cônjuges. Já a "crioulização" elevou a freqüência de laços familiares entre os escravos, particularmente, dentre aqueles que viviam na mesma propriedade, diminuindo a oferta, também, de possíveis noivos. 
As famílias legitimadas foram assinaladas pela endogamia, inicialmente marcante entre os africanos, mas tendendo, após 1850, a conhecer um aumento da representatividade dos crioulos, e das uniões exogâmicas. O perfil foi compatível com o quadro demográfico traçado para o município em estudo.

A endogamia significou que durante a seleção de noivos, os escravos buscaram indivíduos que tivessem uma história e vivência de cativeiro parecidas, ou seja, os africanos, independentemente da procedência, tiveram trajetórias de vida semelhantes, como o desenraizamento, a viagem pelo Atlântico e a busca por refazer suas vidas. Experiência diversa dos crioulos. Estes já tinham nascido na condição de escravos, muito provavelmente naturais do próprio município e inseridos em redes de parentesco, de solidariedades e de amizades.

Em contrapartida, as famílias formadas por mães solteiras tornaram-se comuns. Elas eram, predominantemente africanas, na primeira metade do século XIX, e crioulas, na segunda. Destas, poucas conseguiram legalizar suas uniões e dentre as que conheceram o matrimônio, muitas tinham tido apenas um filho ilegítimo.

As mães casadas tiveram seus filhos em intervalos médios menores que as mães solteiras. Isto aconteceu porque as famílias legitimadas pelo casamento eram formadas por escravos pertencentes ao mesmo senhor, e portanto, facilitando o contato e o convívio entre marido e mulher.

Os filhos estavam praticamente distribuídos de forma equilibrada quanto ao sexo e definiam-se pela ilegitimidade.

As crianças foram batizadas em torno dos seus seis meses de vida e receberam nomes, algumas vezes, em homenagem a seus padrinhos, madrinhas, e em menor freqüência, a seus pais e mães. Prática que demonstrava a preocupação com a transmissão da memória familiar e de ampliação das famílias para além do matrimônio e da consangüinidade, envolvendo compadres e comadres.

Os padrinhos e as madrinhas de crianças legítimas foram predominantemente escravos, demonstrando a preocupação dos pais em ligar seus filhos à realidade e vivência do cativeiro, buscando criar e reforçar vínculos de parentesco, de parceria e de solidariedade entre seus "iguais". 
As mães solteiras buscaram com o compadrio e apadrinhamento, a associação com homens, na primeira e segunda metade do século, e mulheres, na primeira metade do século XIX, livres, respondendo pelo desejo de abertura dos contatos familiares para além da comunidade escrava.

Mesmo diante de um quadro de desânimo econômico, a prática do compadrio não foi alterada. As famílias legitimadas buscaram, em geral, compadres e comadres escravos; enquanto as famílias formadas por mães solteiras, compadres e comadres livres.

Entretanto, pais e mães solteiras, ao longo da segunda metade do século XIX, convidaram mais escravos para o compadrio. Após 1872, quando o número de escravos no município diminuiu, os casais e as mães solteiras selecionaram padrinhos e madrinhas livres, vinculado ao contato mais intenso com os livres.

As famílias foram, em geral, respeitadas no momento da partilha dos bens, facilitando a formação de famílias extensas, constituídas por três ou mais gerações.

Enfim, em meio às transformações econômicas e demográficas, os escravos de Angra dos Reis foram capazes de organizar famílias. Estas não se resumiram aos pais e filhos, mas englobavam avôs, tios, sobrinhos, padrinhos e madrinhas, garantindo a constituição de uma comunidade escrava onde todos, ou quase todos, se conheciam. 


\section{ANEXOS}

\section{ANEXO 1}

Origens e procedências dos noivos por freguesias e subperíodos, Angra dos Reis, 1830-1886

\begin{tabular}{|c|c|c|c|c|c|c|c|c|c|c|}
\hline \multirow[t]{2}{*}{$\begin{array}{l}\text { Origens/proce- } \\
\text { dências }\end{array}$} & \multicolumn{2}{|c|}{$\begin{array}{c}\text { Mambucaba } \\
1830-1849\end{array}$} & \multicolumn{2}{|c|}{$\begin{array}{c}\text { Mambucaba } \\
1850-1875\end{array}$} & \multicolumn{2}{|c|}{$\begin{array}{c}\text { Ilha Grande } \\
\text { 1851-1875 }\end{array}$} & \multicolumn{2}{|c|}{$\begin{array}{c}\text { Ribeira } \\
1851-1886\end{array}$} & \multicolumn{2}{|c|}{$\begin{array}{c}\text { Total } \\
1830-1886\end{array}$} \\
\hline & $\mathrm{HO}$ & MU & $\mathrm{HO}$ & UM & $\mathrm{HO}$ & MU & $\mathrm{HO}$ & MU & $\mathrm{HO}$ & MU \\
\hline Ausentes & 9 & 10 & 7 & 5 & 10 & 10 & 12 & 8 & 38 & 33 \\
\hline Africanos, sem & & & & & & & & & & \\
\hline procedência & 19 & 25 & 8 & 8 & 26 & 20 & 0 & 0 & 53 & 53 \\
\hline Mina & 1 & 0 & 0 & 0 & 0 & 0 & 0 & 0 & 1 & 0 \\
\hline Ambaca & 0 & 0 & 0 & 0 & 1 & 0 & 0 & 0 & 1 & 0 \\
\hline Angola & 1 & 0 & 0 & 0 & 0 & 0 & 0 & 0 & 1 & 0 \\
\hline Benguela & 2 & 5 & 0 & 0 & 3 & 0 & 0 & 0 & 5 & 5 \\
\hline Camundongo & 0 & 0 & 0 & 0 & 1 & 0 & 0 & 0 & 1 & 0 \\
\hline Cabinda & 0 & 0 & 0 & 0 & 2 & 1 & 1 & 1 & 3 & 2 \\
\hline Cassange & 2 & 0 & 0 & 0 & 1 & 2 & 0 & 0 & 3 & 2 \\
\hline Congo & 4 & 2 & 0 & 0 & 6 & 3 & 0 & 0 & 10 & 5 \\
\hline Rebola & 1 & 0 & 0 & 0 & 1 & 0 & 0 & 0 & 2 & 0 \\
\hline Moçambique & 4 & 0 & 0 & 0 & 7 & 0 & 0 & 0 & 11 & 0 \\
\hline Guiné & 11 & 17 & 0 & 0 & 0 & 0 & 30 & 29 & 41 & 46 \\
\hline $\begin{array}{l}\text { Crioulos, sem } \\
\text { procedências }\end{array}$ & 19 & 14 & 8 & 9 & 12 & 35 & 6 & 11 & 45 & 69 \\
\hline Guaratiba & 0 & 0 & 1 & 0 & 0 & 0 & 0 & 0 & 1 & 0 \\
\hline Mangaratiba & 0 & 0 & 0 & 1 & 1 & 0 & 1 & 0 & 2 & 1 \\
\hline Ilha Grande & 0 & 0 & 0 & 0 & 6 & 4 & 0 & 0 & 6 & 4 \\
\hline Conceição & 0 & 0 & 0 & 0 & 0 & 1 & 0 & 0 & 0 & 1 \\
\hline Mambucaba & 0 & 0 & 0 & 0 & 0 & 1 & 0 & 0 & 0 & 1 \\
\hline Ribeira & 0 & 0 & 0 & 1 & 0 & 0 & 0 & 1 & 0 & 2 \\
\hline Total & 73 & 73 & 24 & 24 & 77 & 77 & 50 & 50 & 224 & 224 \\
\hline
\end{tabular}

FONTES: Livro de casamentos de escravos de Mambucaba, 1830-1875; Livro de casamentos de escravos da Ribeira de 1851-1886; e Livro de casamentos de escravos da Ilha Grande de 1851-1875. Convento do Carmo e Igreja de Jacuecanga, Angra dos Reis, RJ.

NOTAS: HO=homens; MU=mulheres. 


\section{ANEXO 2}

Procedências dos adultos africanos batizados por freguesias e subperíodos, Angra dos Reis, 1830-1886

\begin{tabular}{|c|c|c|c|c|c|c|c|c|}
\hline Áreas & $\begin{array}{c}\text { IG } \\
1805- \\
1847\end{array}$ & $\begin{array}{c}\mathrm{R} \\
1824- \\
1826\end{array}$ & $\begin{array}{c}\mathrm{M} \\
1830-1849\end{array}$ & $\begin{array}{c}\mathrm{J} \\
1847-1849\end{array}$ & $\begin{array}{c}\text { IG } \\
1850- \\
1861\end{array}$ & $\begin{array}{c}\mathrm{J} \\
1850-1871\end{array}$ & $\begin{array}{c}\mathrm{M} \\
1850-1871\end{array}$ & Total \\
\hline \multicolumn{9}{|l|}{$\mathrm{AOC}$} \\
\hline Mina HO & 3 & 0 & 0 & 0 & 0 & 0 & 4 & 7 \\
\hline Mina MU & 0 & 0 & 2 & 0 & 0 & 0 & 0 & 2 \\
\hline Calabar HO & 0 & 0 & 0 & 0 & 0 & 0 & 0 & 0 \\
\hline Calabar MU & 0 & 0 & 0 & 0 & 0 & 0 & 0 & 0 \\
\hline Guiné H & 26 & 0 & 17 & 0 & 0 & 0 & 2 & 45 \\
\hline $\begin{array}{c}\text { Guiné MU } \\
\text { ACA }\end{array}$ & 15 & 0 & 11 & 0 & 0 & 0 & 0 & 26 \\
\hline Angola HO & 16 & 0 & 0 & 0 & 0 & 0 & 4 & 20 \\
\hline Angola MU & 5 & 0 & 1 & 0 & 0 & 0 & 0 & 6 \\
\hline Benguela HO & 1 & 0 & 3 & 0 & 0 & 0 & 1 & 5 \\
\hline Benguela MU & 0 & 0 & 1 & 0 & 0 & 0 & 0 & 1 \\
\hline Cabinda HO & 21 & 0 & 0 & 0 & 0 & 0 & 1 & 22 \\
\hline Cabinda MU & 10 & 0 & 2 & 0 & 0 & 0 & 0 & 12 \\
\hline Cassange HO & 5 & 0 & 1 & 0 & 0 & 0 & 0 & 6 \\
\hline Cassange MU & 5 & 0 & 1 & 0 & 0 & 0 & 0 & 6 \\
\hline $\begin{array}{c}\text { Camundongo } \\
\text { HO }\end{array}$ & 4 & 0 & 0 & 0 & 0 & 0 & 0 & 4 \\
\hline $\begin{array}{c}\text { Camundongo } \\
\text { MU }\end{array}$ & 1 & 0 & 0 & 0 & 0 & 0 & 0 & 1 \\
\hline Congo HO & 32 & 0 & 4 & 0 & 0 & 0 & 0 & 36 \\
\hline Congo MU & 14 & 0 & 2 & 0 & 0 & 0 & 0 & 16 \\
\hline Loanda HO & 1 & 0 & 0 & 0 & 0 & 0 & 0 & 1 \\
\hline Loanda MU & 0 & 0 & 0 & 0 & 0 & 0 & 0 & 0 \\
\hline Monjolo HO & 8 & 0 & 0 & 0 & 0 & 0 & 0 & 8 \\
\hline Monjolo MU & 4 & 0 & 0 & 0 & 0 & 0 & 0 & 4 \\
\hline Rebola HO & 1 & 0 & 0 & 0 & 0 & 0 & 1 & 2 \\
\hline $\begin{array}{c}\text { Rebola MU } \\
\text { AOR }\end{array}$ & 1 & 0 & 2 & 0 & 0 & 0 & 0 & 3 \\
\hline $\begin{array}{c}\text { Moçambique } \\
\text { HO }\end{array}$ & 69 & 0 & 5 & 0 & 0 & 0 & 2 & 76 \\
\hline $\begin{array}{c}\text { Moçambique } \\
\text { MU }\end{array}$ & 24 & 0 & 1 & 0 & 0 & 0 & 0 & 25 \\
\hline Quilimane HO & 0 & 0 & 0 & 0 & 0 & 0 & 0 & 0 \\
\hline $\begin{array}{c}\text { Quilimane } \\
\text { MU }\end{array}$ & 1 & 0 & 0 & 0 & 0 & 0 & 0 & 1 \\
\hline SI HO & 48 & 6 & 32 & 0 & 2 & 1 & 39 & 128 \\
\hline SI MU & 18 & 5 & 11 & 0 & 1 & 1 & 6 & 42 \\
\hline Total HO & 235 & 6 & 62 & 0 & 2 & 1 & 54 & 360 \\
\hline Total MU & 98 & 5 & 34 & 0 & 1 & 1 & 6 & 145 \\
\hline
\end{tabular}

FONTES: Livros de batismos de escravos da Ilha Grande, 1805-1847, de 1850-1861; de escravos de Mambucaba, 1830-1871; da Ribeira, de 1824-1826; e de Jacuecanga, 1800-1871. Convento do Carmo e Igreja de Jacuecanga, Angra dos Reis, RJ.

NOTAS: HO=homens; $\mathrm{MU}=$ =mulheres; IG=Ilha Grande; R=Ribeira; M=Mambucaba; J=Jacuecanga; SI=sem informações. 


\section{ANEXO 3}

Procedência dos africanos presentes nos Livros Paroquiais, Angra dos Reis, 1805-1888

\begin{tabular}{|c|c|c|c|c|c|}
\hline Áreas & Mambucaba & Ilha Grande & Ribeira & Jacuecanga & Total \\
\hline \multicolumn{6}{|l|}{ AOC } \\
\hline H Mina & 7 & 15 & 0 & 0 & 22 \\
\hline M Mina & 9 & 4 & 0 & 0 & 13 \\
\hline T Mina & 16 & 19 & 0 & 0 & 45 \\
\hline H Calabar & 0 & 1 & 0 & 0 & 1 \\
\hline M Calabar & 0 & 0 & 0 & 0 & 0 \\
\hline T Calabar & 0 & 1 & 0 & 0 & 1 \\
\hline H Guiné & 34 & 80 & 28 & 0 & 142 \\
\hline M Guiné & 56 & 120 & 28 & 4 & 208 \\
\hline $\begin{array}{c}\text { T Guiné } \\
\text { ACA }\end{array}$ & 90 & 200 & 56 & 4 & 350 \\
\hline H Congo & 18 & 81 & 0 & 0 & 99 \\
\hline M Congo & 21 & 61 & 0 & 0 & 82 \\
\hline T Congo & 21 & 142 & 0 & 0 & 181 \\
\hline H Cassange & 2 & 12 & 0 & 0 & 14 \\
\hline M Cassange & 5 & 29 & 0 & 0 & 34 \\
\hline T Cassange & 7 & 41 & 0 & 0 & 48 \\
\hline H Rebola & 3 & 15 & 0 & 0 & 18 \\
\hline M Rebola & 5 & 36 & 0 & 0 & 41 \\
\hline T Rebola & 8 & 51 & 0 & 0 & 59 \\
\hline H Cabinda & 3 & 40 & 1 & 0 & 44 \\
\hline M Cabinda & 10 & 46 & 1 & 0 & 57 \\
\hline T Cabinda & 13 & 86 & 2 & 0 & 101 \\
\hline H Benguela & 14 & 32 & 0 & 0 & 46 \\
\hline M Benguela & 31 & 79 & 0 & 0 & 110 \\
\hline T Benguela & 45 & 111 & 0 & 0 & 156 \\
\hline H Ambaca & 0 & 1 & 0 & 0 & 1 \\
\hline M Ambaca & 0 & 0 & 0 & 0 & 0 \\
\hline T Ambaca & 0 & 1 & 0 & 0 & 1 \\
\hline H Angola & 8 & 39 & 0 & 2 & 49 \\
\hline M Angola & 15 & 91 & 2 & 1 & 109 \\
\hline T Angola & 23 & 130 & 2 & 3 & 198 \\
\hline H Camundongo & 0 & 5 & 0 & 0 & 5 \\
\hline M Camundongo & 0 & 6 & 0 & 0 & 6 \\
\hline T Camundongo & 0 & 11 & 0 & 0 & 11 \\
\hline H Monjolo & 1 & 8 & 0 & 0 & 9 \\
\hline M Monjolo & 4 & 16 & 0 & 0 & 20 \\
\hline T Monjolo & 5 & 24 & 0 & 0 & 29 \\
\hline H Guanguela & 0 & 2 & 0 & 0 & 2 \\
\hline M Guanguela & 0 & 3 & 0 & 0 & 3 \\
\hline $\begin{array}{c}\text { T Guanguela } \\
\text { AOR }\end{array}$ & 0 & 5 & 0 & 0 & 5 \\
\hline H Moçambique & 16 & 182 & 0 & 0 & 98 \\
\hline M Moçambique & 14 & 54 & 2 & 0 & 168 \\
\hline T Moçambique & 30 & 136 & 2 & 0 & 266 \\
\hline H Quilimane & 0 & 0 & 0 & 0 & 0 \\
\hline
\end{tabular}




\begin{tabular}{clllll} 
M Quilimane & 0 & 1 & 0 & 0 & 1 \\
T Quilimane & 0 & 1 & 0 & 0 & 1 \\
H Inhambane & 1 & 0 & 0 & 0 & 1 \\
M Inhambane & 0 & 2 & 0 & 0 & 2 \\
T Inhambane & 1 & 2 & 0 & 0 & 3 \\
\hline
\end{tabular}

FONTES: Livro de casamentos de escravos de Mambucaba, 1830-1875; Livro de casamentos de escravos da Ribeira, 1851-1886; e Livro de casamentos de escravos da Ilha Grande, 1851-1875. Livros de batismos de escravos da Ilha Grande, de 1805-1847 e de 1850-1861; Livro de batismos de ingênuos da Ilha Grande, 1872-1888; Livro de batismos de escravos de Mambucaba, 1830-1871; Livro de batismos de escravos da Ribeira, de 1824-1826; e Livro de batismos, de casamentos e de óbitos de escravos e de livres de Jacuecanga, 1800-1871. Convento do Carmo e Igreja de Jacuecanga, Angra dos Reis, RJ.

NOTAS: H=Homens; $\mathrm{M}=$ Mulheres; $\mathrm{T}=$ Total. 


\section{ANEXO 4}

Pais de afilhados de Joaquim, crioulo, escravo de Antônio Pinto Soares de Oliveira

1-Ana, crioula, escrava de João Ribeiro Ferreira. Cerimônia realizada em Mambucaba, no ano de 1854.

2-Arcanzia, origem incerta, escrava do Comandante Antônio José Nogueira. Cerimônia realizada em Mambucaba, no ano de 1855.

3-Bárbara crioula, escrava de Manoel Ferreira da Cruz. Batismo realizado em Mambucaba, no ano de 1851.

4-Eleutéria, crioula, cativa de Manoel Jacinto Vieira. Cerimônia realizada em Mambucaba, em 1857.

5-Florinda, crioula, e seu marido, Pedro, escravos de José Jordão da Silva Vargas. Batismo realizado em 1857, em Mambucaba.

6-Ignácia, crioula, cativa de Mariano Ferreira Lousada. Batismo realizado em Mambucaba, em 1854.

7-Isabel, crioula, escrava de Hipólito Maria do Nascimento. Cerimônia realizada em Mambucaba, em 1853.

8-Joana, africana, cativa de João Ribeiro Ferreira. Batismo realizado em Mambucaba, em 1852.

9-A cativa citada acima. Cerimônia realizada em Mambucaba, em 1853.

10-Joana, africana, escrava de José Antônio de Lemos. Batismo realizado em Mambucaba, em 1857.

11-Josefa, africana, cativa de Antônio Alves Magalhães. Batismo ocorrido em Mambucaba, em 1852.

12-Maria, africana do Congo, e seu marido, Pedro, cativos de Francisco Antônio de Lemos. Batismo realizado em 1854, em Mambucaba.

13-Maria, africana, escrava de Francisco Antônio de Lemos. Cerimônia ocorrida em Mambucaba, em 1852.

14-Maria africana, escrava de João Ribeiro Ferreira. Batismo realizado em Mambucaba, em 1858. 
15-Simiana, crioula, escrava de José Jordão da Silva Vargas. Batismo ocorrido em Mambucaba, no ano de 1855.

16-A mesma escrava citada acima. Batismo realizado em Mambucaba, no ano de 1857.

17-Teresa, africana, e seu marido, Benedito, ambos escravos de José Jordão da Silva Vargas. Batismo realizado em Mambucaba, em 1854. 


\begin{abstract}
ANEXO 5
Pais de afilhados e adultos apadrinhados por Francisco Eugênio de Moura
\end{abstract}

1-Anacleta, africana, cativa de Pedro Jordão da Silva Vargas. Cerimônia realizada em Mambucaba, em 1864.

2-Apolinária, origem incerta, escrava de Florentina Guilhermina da Silva Vargas. Batismo realizado em Mambucaba, em 1870.

3-Benedita, crioula, cativa de Manoel Antônio de Oliveira Neves. Cerimônia realizada em Mambucaba, em 1862.

4-Edviges, crioula, cativa de Antônio Jordão da Silva Vargas. Batismo ocorrido em Mambucaba, em 1867.

5-Eva, africana de Moçambique, escrava do Doutor Paulino Corrêa Vidigal. Cerimônia realizada em Mambucaba, em 1864.

6-Felicidade, crioula, cativa do Doutor João Rodrigues Fernandes. Cerimônia realizada em Mambucaba, em 1864.

7-Flaurina, africana, cativa de José Antônio de Lemos. Batismo realizado em Mambucaba, em 1860.

8-Januária, crioula, escrava de Ignácio During. Batismo realizado em Mambucaba, em 1871.

9-Jesuína, crioula, escrava de Dona Mariana Joaquina de Jesus. Cerimônia realizada em Mambucaba, em 1863.

10-Maria, crioula, escrava de Rogéria Maria Antônia. Batismo realizado em Mambucaba, em 1860.

11-Raimunda, crioula, escrava de Vicente Jordão da Silva Vargas. Batismo realizado em Mambucaba, em 1868.

12-Rufina, crioula, pertencente a Pedro Jordão da Silva Vargas. Cerimônia ocorrida em Mambucaba, em 1864.

13-Josefa, africana, propriedade de Luis Antônio Paes de Almeida. Batismo ocorrido em Mambucaba no ano de 1853.

14-A mesma escrava citada acima. Cerimônia realizada em Mambucaba, em 1853. 
15-Alexandrina, de origem incerta, escrava do Capitão Tibúrcio Valeriano de Oliveira Pinto. Batismo ocorrido em Mambucaba, em 1858.

16-Clara, crioula, pertencente a Manoel Pedro Gomes. Batismo realizado em Mambucaba, em 1847.

17-A mesma escrava citada acima. Batismo ocorrido em Mambucaba, em 1852.

18-A mesma escrava citada acima. Cerimônia realizada em Mambucaba, em 1854.

19-Iria, crioula, e seu marido, Marcelino, escravos de Antônio Cordeiro da Silva Guerra. Batismo ocorrido em Mambucaba, em 1849.

20-Os mesmos escravos citados acima. Batismo realizado em Mambucaba, em 1852.

21-Isidora, crioula, cativa de Marcos José Gomes dos santos Pinto. Cerimônia realizada em Mambucaba, em 1853.

22-Joaquina, africana, escrava do Comandante Custódio Ramos Figueira. Batismo realizado em Mambucaba, em 1847.

23-Lucinda, crioula, escrava do Major José Luis Gomes. Cerimônia realizada em Mambucaba, em 1850.

24-Luisa, crioula, escrava de Gonçalo Ferreira do Vale. Batismo realizado em Mambucaba, em 1855.

25-Marcelina, crioula, cativa de Manoel Ferreira da Cruz. Cerimônia realizada em Mambucaba, em 1850.

26-Maria, de origem incerta, e seu marido, Ventura, cativos de José Jordão da Silva Vargas. Batismo realizado em Mambucaba, em 1851.

27-Os mesmos escravos citados acima. Cerimônia realizada em Mambucaba, em 1854.

28-Maria, africana do Congo, escrava de José Ramos. Batismo realizado em Mambucaba, em 1848.

29-Maria, crioula, cativa de Ignácio During. Cerimônia realizada em Mambucaba, em 1854.

30-Rita, africana, propriedade do comandante Custódio Ramos Figueira. Batismo realizado em Mambucaba, em 1847.

31-Um escravo adulto, pertencente a Manoel Luis Gonçalves. Batismo realizado em Mambucaba, em 1847. 
32-Um escravo adulto, propriedade de Luis Antônio Paes de Almeida. Batismo realizado em Mambucaba, em 1849.

33-Um escravo de idade desconhecida, propriedade de Júlio Dufrayer. Cerimônia realizada em Mambucaba, em 1855.

34-Outro escravo de idade desconhecida, cativo de Júlio Dufrayer. Batismo realizado em Mambucaba, em 1855. 
ANEXO 6

Listagem de senhores e respectivos números de propriedades

69 Antônio Alves de Oliveira Lara, Capitão

122 Antônio Francisco Gomes

148 Antônio José de Lemos

169 Antônio Manoel Ferreira da Cruz

236 Cândida Rosa da Conceição, Dona

250 Catarina da Conceição, preta forra

275 Delfim Caetano de Lima

279 Deonisio Fernandes

332 Fernando José da Rocha

351 Francisca das Chagas Figueira

419 Francisco Jordão da Silva Vargas

451 Francisco Pimenta Pontes

466 Geraldino José Fernandes

482 Hermenegildo Alves da Silva Barros

484 Hipólito do rosário

496 Ignácio During

499 Ignácio Gonçalves da Silva Susano

549 José do Rosário

612 João Muller

632 João Ribeiro Ferreira

635 João Rodrigues Fernandes, Doutor

648 Joaquim Antônio Martins Guimarães

678 Joaquim Jordão da Silva Vargas

714 Joaquina Nogueira Barbosa

722 José Alves de Sousa Santos

727 José Antônio de Lemos

732 José Antônio Travassos, Alferes

765 José During

775 José Ferreira da Cruz

812 José Joaquim de Oliveira Reis

814 José Joaquim da Silveira Pinto

818 José Joaquim Teixeira

821 José Jordão da Silva Vargas

822 José Jordão da Silva Vargas Júnior

862 José Rodrigues Pereira

877 Júlio Dufrayer

886 Laurindo Jordão da Silva Vargas

899 Luis Antônio Paes de Almeida

1024 Manoel Joaquim de São Boaventura

1028 Manoel Jordão da Silva Vargas, Tenente

1043 Manoel José Firme, Ajudante

1084 Marcos José Gomes dos Santos Pinto 
1104 Maria do Carmo de Jesus

1133 Vitoriano Marques de Freitas

1174 Paulino Corrêa Vidigal, Doutor

1190 Pedro Jordão da Silva Vargas

1193 Pedro José Travassos

1195 Manoel Ferreira da Cruz

1242 Sebastião, pardo, escravo do Capitão Pedro José Travassos

1278 Tomasia Maria de Jesus 


\author{
ANEXO 7 \\ Listagem de senhores e respectivos números de propriedades \\ 69 Antônio Alves de Oliveira Lara, Capitão \\ 139 Antônio Jordão da Silva Vargas \\ 148 Antônio José de Lemos \\ 169 Antônio Manoel Ferreira da Cruz \\ 250 Catarina da Conceição, preta forra \\ 279 Deonisio Fernandes \\ 332 Fernando José da Rocha \\ 359 Francisca Joaquina Travassos Mc Cormick, Dona \\ 411 Francisco Igidio Guimarães \\ 451 Francisco Pimenta Pontes \\ 466 Geraldino José Fernandes \\ 484 Hipólito do rosário \\ 496 Ignácio During \\ 549 José do Rosário \\ 612 João Muller \\ 632 João Ribeiro Ferreira \\ 635 João Rodrigues Fernandes, Doutor \\ 714 Joaquina Nogueira Barbosa, Dona \\ 727 José Antônio de Lemos \\ 732 José Antônio Travassos, Alferes \\ 765 José During \\ 775 José Ferreira da Cruz \\ 814 José Joaquim da Silveira Pinto \\ 818 José Joaquim Teixeira \\ 821 José Jordão da Silva Vargas \\ 822 José Jordão da Silva Vargas Júnior \\ 862 José Rodrigues Pereira \\ 877 Júlio Dufrayer \\ 894 Lúcio Antônio Barbosa \\ 899 Luis Antônio Paes de Almeida \\ 903 Luis de Carvalho Pinheiro \\ 1016 Manoel Jacinto Vieira \\ 1073 Manoel Rodrigues Fernandes \\ 1084 Marcos José Gomes dos Santos Pinto \\ 1142 Mariana Joaquina de Jesus, Dona \\ 1174 Paulino Corrêa Vidigal, Doutor \\ 1193 Pedro José Travassos \\ 1242 Sebastião, pardo, escravo do Capitão Pedro José Travassos \\ 1287 Vicente Jordão da Silva Vargas
}




\section{APÊNDICE}

\section{APÊNDICE METODOLÓGICO}

Para o estudo utilizamos todos os livros paroquiais referentes aos escravos, existentes no município de Angra dos Reis, datados do século XIX.

Os 10 livros trabalhados, envolvendo batismos e casamentos, foram encontrados no Convento de Nossa Senhora do Carmo de Angra dos Reis, no centro da cidade, e na Igreja de Jacuecanga, em Jacuecanga. Sobre os batismos, fizemos uso dos seguintes livros: livro de batismos de escravos da freguesia de Mambucaba, referente às cerimônias realizadas entre 1830 e 1859, somando 1.261 sacramentos e o livro de batismos de escravos, também de Mambucaba, de 1860 a 1871, totalizando 256 batismos. Para a freguesia da Ribeira, encontramos um livro que registrou os sacramentos realizados entre 1824 e 1826, totalizando 151. Para a freguesia da Ilha Grande localizamos três livros. O primeiro, com batismos entre 1805 e 1830, somando 1.253 sacramentos, o segundo, com 640 cerimônias entre 1847 e 1871 e o terceiro, de 1872 a 1888, com 400 batismos de ingênuos. Por fim, para a freguesia de Jacuecanga, encontramos um livro onde constam batismos, casamentos e óbitos de livres e escravos, datados, segundo informe existente na capa, de 1800 a 1871. Na verdade, os sacramentos que envolveram escravos ocorreram entre 1848 e 1871, somando 245 batismos. Sobre os casamentos, recolhemos os registros existentes em três livros: o livro de casamentos de escravos de Mambucaba, compreendendo 97 sacramentos realizados entre 1830 e 1875, o livro de casamentos de escravos da Ribeira, com 50 cerimônias realizadas entre 1851-1886 e o livro de casamentos de escravos da Ilha Grande, com 77 casamentos, de 1851 a 1875.

Com exceção dos registros onde constaram doações, alforrias e batismos em “perigo de vida”, eles seguiram o modelo apresentado abaixo: 
“Aos vinte e oito do mês de janeiro de mil oito centos e cincuenta e quatro nesta Igreja Matriz de Santa Ana da Ilha Grande baptizei e pus os santos óleos a Firmina nascida a sete de abril do ano passado, filha de pai incógnito e de Maria Antonia crioula escrava de Manoel Rodrigues. Foi Protetora Nossa Senhora e padrinho Antonio Manoel Felício. E para constar mandei fazer este assento que assignei.

Vigário José Teixeira de Matos”198

Deste material foram anotados os seguintes dados: data, local da cerimônia, nome do batizando, data de nascimento ou idade, cor (pouco citada), nome dos pais, suas origens (“de nação” ou crioulos), procedências (Angola, Mina etc), nomes de padrinhos e madrinhas, condições jurídicas (escravos, forros, livres), origens, procedências e nome de proprietários. Para os adultos batizandos foram recolhidos os mesmos informes, excluindo apenas os dados sobre os pais, visto que eram praticamente todos africanos. Anotamos também informações complementares que consideramos pertinentes.

No caso dos registros de ingênuos, a única diferença dizia respeito à especificação de que as crianças, embora filhas de escravas, eram livres pela Lei de 28 de setembro de 1871, decreto $n^{\circ} 2040$.

Os registros de casamentos, excluindo os casos de sacramentos realizados em oratórios e residências, foram semelhantes ao descrito a seguir:

“Aos seis dias do mês de novembro de mil oito centos e trinta e um, nesta provincial Igreja de Nossa Senhora do Rosário de Mambucaba, depois de proclamada em três dias santos, sem impedimentos e feitos as mais diligências na forma do Sagrado Concílio Tridentino e Constituição do Bispado em minha presença e das testemunhas Antônio Manoel Gomes e José Joaquim da Costa pela huma hora da tarde receberão em matrimônio com palavras do presente Antônio com Maria ambos de nação da Guiné, escravos do sargento mor José Joaquim Guimarães, receberão as bênçãos na forma do ritual romano e para constar fiz este assento.

Vigário Encomendado Antônio Norberto de Affonso”199.

\footnotetext{
${ }^{198}$ Livro de batismos de escravos da Ilha Grande, 1847-1871. Igreja de Jacuecanga, Angra dos Reis, RJ.

${ }^{199}$ Livro de casamentos de escravos de Mambucaba, 1830-1871. Convento do Carmo, Angra dos Reis, RJ.
} 
Os informes recolhidos foram: a data, o local da cerimônia, o nome dos cônjuges, as suas origens, a cor, as procedências, o nome dos pais, o nome dos proprietários e das testemunhas.

Os dois tipos de registros, marcando determinados momentos na vida de homens e mulheres escravizados, como o nascimento e o casamento, tiveram até a proclamação da República, em 1889, a função de registros civis.

Todo o material do qual usufruímos pode ser observado a partir do estado de conservação dos livros, do conteúdo dos registros e de suas distribuições cronológicas.

Acerca do estado de conservação dos livros, os de batismos estão, em geral, em “boas” condições, excluindo o livro de ingênuos que, embora mais recente, possui folhas em péssimo estado, impossibilitando a coleta de alguns registros. Situação mais complicada foi encontrada nos livros de casamentos, onde a umidade e as traças tornaram a leitura, muitas vezes, difícil. As condições de armazenamento dos livros, ao nosso ver, podem ser apontadas como o principal problema para a feitura do trabalho e, por certo, foi o motivo para a perda de muitos livros. Por exemplo, no que se refere a Mambucaba, não temos informações sobre os batismos realizados até 1829 e após 1871, havendo apenas informações para 41 anos e sobre casamentos foram cobertos apenas 45 anos, não existindo livros com registros datados até 1829 e após 1875. No que tange a Ribeira, existem informações para batismos realizados durante dois anos, faltando os registros datados até 1823 e os de 1827 em diante. No que se referem aos casamentos, os dados cobrem 35 anos, ficando de fora as cerimônias realizadas até 1850 e após 1871. No caso de Jacuecanga, freguesia criada na década de 1850, os registros de batismos existentes cobrem 23 anos, faltando informações para os anos anteriores a 1842 e posteriores a 1872, não havendo nenhuma alusão aos casamentos. Para a freguesia da Conceição, atual centro da cidade, não encontramos nenhum livro do século XIX relativo aos escravos. Em contrapartida, da Ilha Grande possuímos 70 anos de batismos de escravos e de ingênuos, ficando de fora os sacramentos efetuados até 1804 e de 1862 a 1871, enquanto no que se refere aos casamentos temos 24 anos, faltando os registros realizados até 1850 e após 1876.

Os dados que dispomos são como retratos sobre os batismos e os casamentos, e oferecem informações suficientes para a análise proposta. Ao mesmo tempo, a questão 
apresentada demonstra a falta de uma política efetiva de conservação da memória da Igreja, quer por falta de verbas quer por falta de interesse.

A segunda observação refere-se ao conteúdo dos registros. Os de batismos mostraram-se mais completos, havendo, inclusive, uma variação qualitativa dos informes, se diferenciando dos registros de Campos, no estado do Rio de Janeiro, menos informativos que os de casamentos (FARIA, 1998, p. 309).

Os livros que apresentam maior variedade de informações são o livro relativo à Ilha Grande, compreendendo os batismos de 1805-1830, onde 44,9\% (565 de 1299) das cerimônias possuíam dados relativos a, entre outros, batismos "em perigo de vida"; os estados conjugais, nomes dos pais, locais de residência e profissões de padrinhos e de madrinhas; alforrias de batizandos; entre outros. E o livro de batismos da Ribeira, de 1824 a 1826, onde 47,7\% (72 de 151) dos sacramentos traziam, por exemplo, os nomes dos avós paternos e maternos, doações e as condições conjugais dos proprietários.

No caso dos casamentos, os dados mais relevantes, além daqueles que geralmente constavam nos registros, dizem respeito aos nomes dos pais dos noivos. Embora raros, foram mais comuns entre os registros da Ilha Grande, onde 15,6\% (12 de 77) dos noivos e 20,8\% (16 de 77) das noivas tiveram seus pais indicados. Essas anotações não foram, por exemplo, comuns nos registros de Campos, estudados por Faria (1998, p. 309).

A respeito do sacramento vimos também em três cerimônias a indicação a quatro testemunhas e duas cerimônias com três testemunhas. O número excedia o estipulado pela Igreja, que exigia o comparecimento de duas testemunhas.

Enfim, a qualidade das informações resultava do cuidado do vigário na hora da redação dos registros. Pelo que parece, na comparação entre os livros trabalhados, o vigário responsável pela Ilha Grande demonstrou mais cuidado, anotando maior variedade de dados sobre os envolvidos nos sacramentos dos batismos e dos casamentos.

A terceira nota diz respeito à disposição cronológica dos registros. Os livros de casamentos, além do pior estado de conservação e menor quantidade de informes acerca dos envolvidos, possuíam maior freqüência de registros anotados sem nenhuma ordem cronológica. Temos, por exemplo, um registro de 20 de junho anotado antes de um casamento de janeiro do mesmo ano. Além de dois registros que pararam no meio, apontando para uma possível interrupção do vigário na hora da transcrição. Esses fatos 
nos levam a crer que foram passados a limpo de um outro livro ou de uma folha solta. Já os registros de batismos, por sua vez, estavam em ordem cronológica.

A anotação de muitos registros de casamentos sem ordenação cronológica e a interrupção de dois assentos no meio levantam a questão: os vigários tiveram algum cuidado na hora de passar os registros a limpo? Parece que não. Isto deixa implícito a possível fragilidade das fontes. Entretanto, a mesma foi amenizada após o cruzamento dos informes com os de outros registros de batismos e os constantes nos inventários.

A respeito de quem teria oferecido as informações anotadas pelos vigários, Faria (1998, p. 311), em seu estudo sobre Campos, considerou que foram apresentadas pelos cativos, parentes e padrinhos. A afirmação está baseada no fato de que nem sempre os senhores estiveram presentes nos sacramentos, visto que as cerimônias foram realizadas, geralmente, na igreja, e não compareceram, muitas vezes, na qualidade de padrinhos e madrinhas de seus escravos. Também não teriam sido dadas pelos vigários pois, possivelmente, não tinham conhecimento de todos os moradores das paróquias e nem das origens dos cativos. A interpretação e a redação final ficavam a cargo do vigário: “presumo terem sido os padres os verdadeiros filtros das informações dos registros. Além do mais, está claro que eles nem sempre transcreviam imediatamente para o livro a cerimônia realizada” (FARIA, 1998, p. 311).

Após o recolhimento do material, os escravos citados nos registros foram unidos em torno do nome de seus proprietários. No caso de senhores com nomes parecidos, como José Jordão Vargas e José Jordão da Silva Vargas, escravistas de Mambucaba e da Ilha Grande, comparamos os nomes e outros dados, como origem e procedência, de seus escravos. Havendo semelhanças nos informes, consideramos os proprietários com nomes parecidos, como sendo a mesma pessoa.

Proprietários que eram marido e mulher e que foram indicados como senhores de escravos com nomes, origens, procedências etc, semelhantes, tiveram seus escravos reunidos em torno do nome do cônjuge.

Posteriormente, numeramos os proprietários e seus cativos. Neste momento, foi possível preencher informações ausentes em alguns registros e que constaram em outros acerca de um mesmo escravo. Foi o caso, por exemplo, de Bonifácia, crioula, e seu marido João, também crioulo. Os dois batizaram o filho Vidal, em 1812, na Ilha Grande. 
No ano de 1818, compareceram ao batismo da filha Guiria dois cativos de nome Bonifácia e João, ambos com origem não determinada e escravos do mesmo proprietário do casal anteriormente mencionado, o Padre Antônio de Matos da Nóbrega. Observando a listagem dos cativos que compareceram aos sacramentos de batismo e de casamento e que pertenciam ao citado padre, verificamos a existência de dois casais de cativos com aqueles nomes. Ao lado da constatação que o intervalo entre o nascimento do primeiro filho, em 30 de abril de 1811, e do segundo, nascido em 20 de outubro de 1818, seria perfeitamente compatível, levou-nos a concluir que tratava-se das mesmas pessoas e acabamos considerando a origem dos segundos como crioulos.

Nos inventários, todos localizados no Museu da Justiça do Estado do Rio de Janeiro, anotamos as informações relativas ao patrimônio do inventariado, incluindo todos os informes acerca de seus escravos, quando possuíam. Nos processos posteriores a 1872, encontramos alguns onde constavam as matrículas de escravos, de 1872.

Após o levantamento dos inventários, cruzamos os dados localizados para os escravos, a partir dos nomes de seus proprietários e organizamos os plantéis, unindo o máximo de informações possíveis, existentes nos documentos paroquiais e cartorários. Consideramos, então, as fontes prontas para a realização do trabalho. 


\section{REFERÊNCIAS BIBLIOGRÁFICAS}

FONTES:

Almanak Laemmert, anos pares entre 1844 e 1882 e anos de 1883 e 1885. <uchicago.edu/info/brazil/almanak2.htm>; Biblioteca Nacional, Rio de Janeiro, RJ; Instituto Histórico e Geográfico Brasileiro (IHGB), Rio de Janeiro, RJ.

ANTONIL, André João. Cultura e Opulência do Brasil. Belo Horizonte/São Paulo: Itatiaia/Edusp, 1982.

ARAUJO, José de Souza Azevedo Pizarro e. Memórias históricas do Rio de Janeiro. Rio de Janeiro: Imprensa Nacional, 1945. vol.2.

CASAL, Aires de. Corografia Brasílica. Belo Horizonte/São Paulo: Itatiaia/Edusp, 1976.

Censo Nacional de 1872. Instituto Brasileiro de Geografia e Estatística (IBGE), Rio de Janeiro, RJ.

KIDDER, Daniel P. Reminiscências de viagens e permanências nas províncias do sul do Brasil (Rio de Janeiro e Província de São Paulo). Belo Horizonte/São Paulo: Itatiaia/Edusp, 1980.

Inventários post-mortem de Angra dos Reis, 1800-1888. Angra dos Reis, RJ. Museu da Justiça do Estado do Rio de Janeiro, RJ.

Jornal do Comércio, de 1827 a 1888. Biblioteca Nacional, Rio de Janeiro, RJ.

Livro de batismos de escravos da Freguesia da Ilha Grande, 1805-1830. Igreja de Jacuecanga, Angra dos Reis, RJ. 
Livro de batismos de escravos da Freguesia da Ilha Grande, 1847-1861. Igreja de Jacuecanga, Angra dos Reis, RJ.

Livro de batismos de filhos de escravas da Freguesia da Ilha Grande, 1872-1888. Igreja de Jacuecanga, Angra dos Reis, RJ.

Livro de casamentos de escravos da Freguesia da Ilha Grande, 1851-1875. Igreja de Jacuecanga, Angra dos Reis, RJ.

Livro de batismos de escravos da Freguesia de Mambucaba, 1830-1859. Convento do Carmo, Angra dos Reis, RJ.

Livro de batismos de escravos da Freguesia de Mambucaba, 1860-1871. Convento do Carmo, Angra dos Reis, RJ.

Livro de casamentos de escravos da Freguesia de Mambucaba, 1830-1875. Convento do Carmo, Angra dos Reis, RJ.

Livro de batismos de escravos da Freguesia da Ribeira, 1824-1826. Convento do Carmo, Angra dos Reis, RJ.

Livro de casamentos de escravos da Freguesia da Ribeira, 1851-1886. Convento do Carmo, Angra dos Reis, RJ.

Livro de batismos, casamentos e óbitos de livres e de escravos da Freguesia de Jacuecanga, 1800-1871. Igreja de Jacuecanga, Angra dos Reis, RJ.

LUCCOCK, John. Notas sobre o Rio de Janeiro e partes meridionais do Brasil. Belo Horizonte/São Paulo: Itatiaia/Edusp, 1975.

POHL, Johann Emanuel. Viagem ao interior do Brasil. Belo Horizonte: Itatiaia, 1976. 
SPIX \& MARTIUS. Viagem pelo Brasil (1817-1820). Belo Horizonte: Itatiaia, 1981. vol. 1

Relatórios de Presidentes de Província do Rio de Janeiro, anos de 1841, de 1851 e de 1858. Biblioteca Nacional, Rio de Janeiro, RJ.

RUGENDAS, João Maurício. Viagem pitoresca através do Brasil. Belo Horizonte/São Paulo: Editora Itatiaia/Edusp, 1979.

ZALUAR, Augusto Emílio. Peregrinação pela Província de São Paulo (1860-1861). Belo Horizonte/São Paulo: Itatiaia/Edusp, 1975.

LIVROS, ARTIGOS, DISSERTAÇÕES E TESES:

ALMADA, Vilma Paraíso Ferreira de. Escravismo e transição. O Espírito Santo (1850/1888). Rio de Janeiro: Graal, 1984.

ALMEIDA, Carla Maria C. de. Demografia e laços de parentesco na população escrava mineira: Mariana, 1750-1850. População e Família, São Paulo, vol. 1, n 1, p. 235-260, jan./jun. 1998.

ANDRADE, Rômulo Garcia de. Limites impostos pela escravidão à comunidade escrava e seus vínculos de parentesco: Zona da Mata de Minas Gerais, século dezenove. A subjetividade do escravo perante a coisificação social própria do escravismo. São Paulo: 1995. Tese (Doutorado em História Social)-USP.

Família escrava e estrutura agrária na Minas Gerais oitocentista. População e Família, São Paulo, vol. 1, n 1, p. 181-209, jan./jun. 1998. 
ARANTES, Antônio Augusto. Pais, padrinhos e o Espírito Santo. Um estudo do compadrio. In: ARANTES, Antônio Augusto et al. Colcha de retalhos. Estudos sobre a família no Brasil. Campinas: Editora da Unicamp, s.d. p. 195-206.

BACELLAR, Carlos de Almeida Prado. Viver e sobreviver em uma vila colonial. Sorocaba, séculos XVIII e XIX. São Paulo: Annablume/FAPESP, 2001.

BERGARD, Laird W. Escravidão e história econômica. Demografia de Minas Gerais, 1720-1888. São Paulo: EDUSC, 2004.

BOTELHO, Tarcísio Rodrigues. Famílias e escravarias. Demografia e família escrava no norte de Minas Gerais no século XIX. São Paulo: 1994. Dissertação (Mestrado em História Social)-USP.

.População e nação no Brasil do século XIX. São Paulo: 1998a. Tese (Doutorado em História Social)-USP.

Famílias e escravarias: demografia e família escrava no norte de Minas Gerais no século XIX. População e Família, São Paulo, vol. 1, n 1, p. 211-234, jan./jun. 1998b.

BRANDÃO, Sylvana. Ventre livre, mãe escrava. A reforma social de 1871 em Pernambuco. Recife: Ed.da UFPE, 1996.

CAPAZ, Camil. Memórias de Angra dos Reis. Rio de Janeiro: edição do autor, 1996.

CARDOSO, Ciro Flamarion \& VAINFAS, Ronaldo (orgs.). Domínios da História. Ensaios de Teoria e Metodologia. Rio de Janeiro: Campus, 1997. 
CARDOSO, Fernando Henrique. Capitalismo e escravidão no Brasil Meridional. O negro na sociedade escravocrata do Rio Grande do Sul. São Paulo: Difusão Européia do Livro, 1962.

CARVALHO, Marcus J. M. de. Liberdade. Rotinas e rupturas do escravismo. Recife, 1822-1850. Recife: Editora da UFPE, 1998.

CASTRO, Hebe Maria Mattos. Ao sul da história. Lavradores pobres na crise do trabalho escravo. São Paulo: Brasiliense, 1987.

Das cores do silêncio. Os significados da liberdade no sudeste escravista-Brasil, século XIX. Rio de Janeiro: Arquivo Nacional, 1995.

. Laços de família no final da escravidão. In: ALENCASTRO, Luiz Felipe de (org.) História da vida privada no Brasil. Império: A Corte e a Modernidade Nacional. São Paulo: Companhia das Letras, 1997. vol. 2, p. 337-383.

CHALHOUB, Sidney. Visões da liberdade. Uma história das últimas décadas da escravidão na corte. São Paulo: Companhia das Letras, 1990.

CYRANKA, Lúcia Furtado de Mendonça \& SOUZA, Vânia Pinheiro de. Orientações para normalização de trabalhos acadêmicos. 2 ed. Juiz de Fora: Editora da UFJF, 1997.

COSTA, Emília Viotti da. Da senzala à colônia. 3 ed. São Paulo: Unesp, 1998.

COSTA, Iraci del Nero. Vila Rica: população (1819-1826). São Paulo: IPE/USP, 1979.

, SLENES, Robert \& SCHWARTZ, Stuart B. A família escrava em Lorena (1801). Estudos Econômicos, São Paulo, vol. 17, n 2, p. 246-295, maio/ago. 1987. 
COSTA, Iraci del Nero \& NOZOE, Nelson. Elementos da estrutura de posse de escravos em Lorena no alvorecer do século XIX. Estudos Econômicos, São Paulo, vol. 19, n 2, p. 319-345, maio/ago. 1989.

\& GUTIÉRREZ, Horácio. Nota sobre casamentos de escravos em São Paulo e no Paraná (1830). História: Questões e Debates, Curitiba, vol. 5, n. 9, p. 313-321, dez. 1984.

\& LUNA, Francisco Vidal. Minas Gerais: economia e sociedade.

São Paulo: FIPE, 1982.

CUNHA, Antônio Geraldo de. Dicionário etimológico Nova Fronteira da língua portuguesa. 2 ed. Rio de Janeiro: Nova Fronteira, 1982.

DAIBERT JÚNIOR, Robert. Isabel. A “ redentora” dos escravos. São Paulo: EDUSC, 2004.

EL-KAREH, Almir Chaiban. Filha branca de mãe preta: A Companhia da Estrada de Ferro D. Pedro II (1855-1865). Petrópolis: Vozes, 1982.

Enciclopédia dos municípios brasileiros. Rio de Janeiro: IBGE, 1959. vol. 6.

FARIA, Sheila de Castro. Família escrava e legitimidade. Estratégias de preservação da autonomia. Estudos Afro-Asiáticos, Rio de Janeiro, n. 23, p. 113-131, dez. 1992. . História da família e demografia histórica. In: CARDOSO, Ciro Flamarion \& VAINFAS, Ronaldo (orgs.). Domínios da história. Ensaios de teoria e metodologia. Rio de Janeiro: Campus, 1997. p. 241-258.

.A colônia em movimento Fortuna e família no cotidiano colonial. Rio de Janeiro: Nova Fronteira, 1998. 
FARIA, Sheila de Castro. Negros de Guiné. In: VAINFAS, Ronaldo (org.). Dicionário do Brasil Colonial (1500-1808). Rio de Janeiro: Objetiva, 2001. p. 424.

FERNÁNDEZ, Ramón Vicente Garcia. Transformações econômicas no litoral nortepaulista (1778-1836). São Paulo: 1992. Tese (Doutorado em Economia)-USP.

FERREIRA, Aurélio Buarque de Holanda. Novo dicionário da língua portuguesa. 2 ed. Rio de Janeiro: Nova Fronteira, 1986.

FERREIRA, Roberto Guedes. Na pia batismal. Família e compadrio entre escravos na freguesia de São José do Rio de Janeiro (primeira metade do século XIX). Niterói: 2000. Dissertação (Mestrado em História)-UFF.

FLORENTINO, Manolo Garcia. Em costas negras: uma história do tráfico atlântico de escravos entre a África e o Rio de Janeiro (séculos XVIII e XIX). Rio de Janeiro: Arquivo Nacional, 1995.

\& GÓES, José Roberto. A paz das senzalas. Famílias escravas e tráfico atlântico, Rio de Janeiro, c. 1790-c. 1850. Rio de Janeiro: Civilização Brasileira, 1997.

Morfologias da infância escrava:

Rio de Janeiro, séculos XVIII e XIX. In: FLORENTINO, Manolo (org.). Tráfico, cativeiro e liberdade. Rio de Janeiro: Civilização Brasileira, 2005. p. 207-227.

Sobre minas, crioulos e a liberdade costumeira no Rio de Janeiro, 1789-1871. In: FLORENTINO, Manolo (org.). Tráfico, cativeiro e liberdade. Rio de Janeiro: Civilização Brasileira, 2005. p. 331-366. 
FLORENTINO, Manolo Garcia \& MACHADO, Cacilda. Migrantes portugueses, mestiçagem e alforrias no Rio de Janeiro imperial. In: FLORENTINO, Manolo (org.). Tráfico, cativeiro e liberdade. Rio de Janeiro: Civilização Brasileira, 2005. p. 367-388.

(orgs.). Ensaios sobre a escravidão.

Belo Horizonte: Editora UFMG, 2003.

FRAGOSO, João Luís. Homens de grossa aventura: acumulação e hierarquia na praça mercantil do Rio de Janeiro (1790-1830). Rio de Janeiro: Arquivo Nacional, 1992.

\& FLORENTINO, Manolo Garcia. Marcelino, filho de Inocência Crioula, neto de Joana Cabinda: um estudo sobre famílias escravas em Paraíba do Sul (1835-1872). Estudos Econômicos, São Paulo, n 17, vol. 2, p. 151-173, maio/ago. 1987.

\& RIOS, Ana Maria Lugão. Um empresário brasileiro do oitocentos. In: CASTRO, Hebe Maria Mattos de \& SCHNOOR, Eduardo (orgs.). Resgate: uma janela para o oitocentos. Rio de Janeiro: Toopbooks, 1995. p. 197-224.

FRANÇA, Júnia Lessa et al. Manual para normalização de publicações técnicocientíficas. 4 ed. Belo Horizonte: Editora da UFMG, 1999.

FREYRE, Gilberto. Casa grande e senzala. 28 ed. Rio de Janeiro: Record, 1992.

FRIDMAN, Fania. Donos do Rio em nome do Rei. Uma história fundiária da cidade do Rio de Janeiro. 2 ed. Rio de Janeiro: Jorge Zahar/Garamond, 1999.

GÓES, José Roberto. O cativeiro imperfeito. Um estudo sobre a escravidão no Rio de Janeiro da primeira metade do século XIX. Vitória: Lineart, 1993. 
GÓES, José Roberto. Escravos da paciência. Estudo sobre a obediência escrava no Rio de Janeiro (1790-1850). Niterói: 1998. Tese (Doutorado em História Social)-UFF.

GENOVESE, Eugene. A terra prometida. O mundo que os escravos criaram. Trad. Maria Inês Rolim, Donaldson Magalhães Garschagen. Rio de Janeiro: Paz e Terra, 1988.

GINZBURG, Carlo. A micro-história e outros ensaios. Lisboa/Rio de Janeiro: Difel/Bertrand, 1989.

GODOY, Marcelo Magalhães. Reconstituindo o movimento no tempo de uma estrutura da posse de escravos (Bonfim, 1832-1839). Revista de História, Ouro Preto, v. 3, n. 1, p. 67-79, 1992.

GORENDER, Jacob. O escravismo colonial. 6 ed. São Paulo: Ática, 1992.

A escravidão reabilitada. São Paulo: Ática, 1990.

Brasil em Branco \& Preto. O passado escravista que não passou. São Paulo: Editora SENAC, 2000.

GRAHAM, Richard. A família escrava no Brasil colonial. In.: . Escravidão, reforma e imperialismo. São Paulo: Perspectiva, 1979. p. 41-57.

GUDEMAN, Stephen \& SCHWARTZ, Stuart. Purgando o pecado original: compadrio e batismo de escravos na Bahia no século XVIII. In: REIS, João José (org.). Escravidão e invenção da liberdade. São Paulo: Brasiliense, 1988. p. 33-59.

GURGEL, Heitor \& AMARAL, Edelweiss. Paraty, caminho do ouro. Rio de Janeiro: Livraria São José, 1973. 
GUTIERRÉZ, Horácio. Senhores e escravos no Paraná, 1800-1830. São Paulo: 1986. Dissertação (Mestrado em Economia)-USP.

GUTMAN, Herbert. The black family in slavery and freedom, 1750-1925. New York: Pantheon, 1976.

HOLLANDA, Sérgio Buarque de (org.). HGCB. O Brasil Monárquico: Dispersão e unidade. São Paulo: Difel, 1985.

KARASCH, Mary C. A vida dos escravos no Rio de Janeiro, 1808-1850. São Paulo: Cia das Letras, 200a. . "Minha nação": identidades escravas no fim do Brasil Colonial. In: SILVA, Maria Beatriz Nizza da (org.). Brasil. Colonização e escravidão. Rio de Janeiro: Nova Fronteira, 2000b. p. 127-141.

KLEIN, Herbert S. A demografia do tráfico atlântico de escravos para o Brasil. Estudos Econômicos, São Paulo, vol. 17, n 2, p. 129-149, maio/ago. 1987.

KNOX, Miridan Brito. Escravos do sertão. Demografia, trabalho e relações sociais. Piauí, 1826-1888. São Paulo: 1993. Tese (Doutorado em História Social)-USP.

LAMEGO, Alberto Ribeiro. O Homem e a Guanabara. 2 ed. Rio de Janeiro: IBGE, 1964.

. O Homem e a Serra. 2 ed. Rio de Janeiro: IBGE, 1963.

LARA, Sílvia Hunold. Campos da violência. Escravos e senhores na Capitania do Rio de Janeiro, 1750-1808. Rio de Janeiro: Paz e Terra, 1988. 
LEBRUN, François. O sacerdote, o príncipe e a família. In: BURGUIÈRE, André et al. (orgs). $\mathbf{O}$ choque das modernidades. Ásia, África, América e Europa. Lisboa: Terramar, 1998. vol 3, p. 8-134.

LIBBY, Douglas Cole. Transformação e trabalho em uma economia escravista. Minas Gerais no século XIX. São Paulo: Brasiliense, 1988.

LIMA, Honório. Notícia histórica e geográfica de Angra dos Reis. 2 ed. Angra dos Reis: Prefeitura Municipal, 1972.

LOURENÇO, Luís Augusto Bustamante. A oeste das Minas. Escravos, índios e homens livres numa fronteira oitocentista. Triângulo Mineiro (1750-1861). Uberlândia: Editora da UFU, 2002.

LUNA, Francisco Vidal. Estrutura de posse de escravos e atividades produtivas em Jacareí (1777 a 1829). Revista do Instituto de Estudos Brasileiros, São Paulo, n 28, p. 23-35, 1988. . Casamento de escravos em São Paulo, 1776, 1804, 1825. In.: CONGRESSO SOBRE A HISTÓRIA DA POPULAÇÃO DA AMÉRICA LATINA, 1989, Ouro Preto. História e População: estudos sobre a América Latina. São Paulo. Fundação Sistema Estadual de Análise de Dados, 1990. p. 226-236.

Características demográficas dos escravos de São Paulo (17771829). Estudos Econômicos, São Paulo, vol. 22, n 3, p. 443-483, set./dez. 1992.

Areias: posse de escravos e atividades econômicas (18171836). São Paulo:NEHD-FEA/USP, 1995. 
LUNA, Francisco Vidal. São Paulo: população, atividades e posse de escravos em vinte e cinco localidades (1777-1829). Estudos Econômicos, São Paulo, v. 28, n. 1, p. 99-169, jan./mar. 1998.

\& COSTA, Iraci del Nero da. Vila Rica: notas sobre casamentos

de escravos (1727-1826). África. Revista do Centro de Estudos Africanos da USP, São Paulo, n. 4, p. 105-109, 1981.

\& KLEIN, Herbert S. Evolução da sociedade e economia escravista de São Paulo, de 1750 a 1850. São Paulo: EDUSP, 2005.

MACHADO, Lia Osório. História da ocupação. Rio de Janeiro: UFRJ, s. d. (mimeografado).

MACHADO, Maria Helena P. T. Crime e escravidão. Trabalho, luta e resistência nas lavouras paulistas, 1830-1888. São Paulo: Brasiliense, 1987.

. Em torno da autonomia escrava: uma nova direção para a história social da escravidão. Revista Brasileira de História, São Paulo, vol. 8, n. 16, p. 143-160, mar./ago. 1988.

MARCÍLIO, Maria Luiza. Caiçara: terra e população. Estudo da demografia histórica e história social de Ubatuba. São Paulo: Paulinas/CEDHAL, 1986.

A cidade de São Paulo. Povoamento e população. 1750-1850. São Paulo: Pioneira/Edusp, 1974.

. Caiçara: terra e população. Estudo de demografia histórica e da história social de Ubatuba. São Paulo: Paulinas/CEDHAL, 1986. 
MARCONDES, Renato Leite. O evolver demográfico e econômico nos espaços fluminenses (1789-1840). Estudos Econômicos, São Paulo, vol. 25, n 2, p. 235-270, maio/ago. 1995.

A arte de acumular na economia cafeeira. Vale do Paraíba, século XIX. Lorena: Stiliano, 1998.

A propriedade escrava no vale do Paraíba paulista durante a década de 1870. São Paulo:USP, 2000.

MARTINHO, Lenira Menezes \& GORENSTEIN, Riva. Negociantes e caixeiros na sociedade da Independência. Rio de Janeiro: Prefeitura da Cidade do Rio de Janeiro, 1993.

MENDES, Alípio. Ouro, incenso e mirra. Angra dos Reis: Gazeta de Angra, 1970.

A Santa Casa de Angra. Rio de Janeiro: Livraria São José, 1972.

.O Convento de Nossa Senhora do Carmo da Ilha Grande. Angra dos Reis: edição do autor, 1980.

. O Velho Convento. 2 ed. Angra dos Reis: edição do autor, 1991.

Angra dos Reis. Da criação da vila até sua transferência para a atual cidade (1502-1624). Angra dos Reis: Ateneu Angrense de Letras e Artes, 1995.

METCALF, Alida. Vida familiar dos escravos em São Paulo no século XVIII: o caso de Santana de Parnaíba. Estudos Econômicos, São Paulo, n. 17, p. 205-212, 1987.

A família escrava no Brasil colonial. In.: CONGRESSO SOBRE A HISTÓRIA DA POPULAÇÃO DA AMÉRICA LATINA, 1989, Ouro Preto. História e 
População: estudos sobre a América Latina. São Paulo. Fundação Sistema Estadual de Análise de Dados, 1990. p. 205-212.

MOTTA, José Flávio. Corpos escravos, vontades livres. Posse de escravos e família escrava em Bananal (1801-1829). São Paulo: FAPESP/Annablume, 1999a.

. The historical demography of Brazil at the $V$ centenary of its Discovery. Ciência e Cultura: Journal of the Brazilian Association for the Advancement of Science, vol. 51, n 5/6, p. 446-456, sept./dec. 1999b.

Demografia histórica, família escrava e historiografia: relações familiares em um plantel de escravos de Apiaí (SP). In: CONGRESSO BRASILEIRO DE HISTÓRIA ECONÔMICA E CONFERÊNCIA INTERNACIONAL DE HISTÓRIA DE EMPRESAS, IV e 5, 2001, São Paulo. CD Rom. São Paulo, 2001. p. 1-25.

A família escrava na historiografia brasileira. Os últimos vinte e cinco anos. In: SAMARA, Eni de Mesquita. Historiografia brasileira em debate: “olhares, recortes e tendências”. São Paulo: Humanitas, 2002. p. 235-254.

\& MARCONDES, Renato Leite. A família escrava em Lorena $e$ Cruzeiro (1874). População e Família, São Paulo, n 3, p. 93-128, 2000.

, NOZOE, Nelson \& COSTA, Iraci Del Nero da. Às vésperas da abolição. Um estudo sobre a estrutura de posse de escravos em São Cristóvão (RJ), 1870. São Paulo, s. d. (mimeografado).

MOURA, Clóvis. Dicionário da escravidão negra no Brasil. São Paulo: EDUSP, 2004.

NEVES, Maria de Fátima R. Ampliando a família escrava: compadrio de escravos em São Paulo do Século XIX. In.: CONGRESSO SOBRE A HISTÓRIA DA POPULAÇÃO DA AMÉRICA LATINA, 1989, Ouro Preto. História e População: estudos sobre a 
América Latina. São Paulo. Fundação Sistema Estadual de Análise de Dados, 1990. p. 237-243.

PAIVA, Clotilde Andrade. População e economia nas Minas Gerais do século XIX. São Paulo: 1996. Tese (Doutorado em História Social)-USP.

\& KLEIN, Herbert S. Escravos e livres nas Minas Gerais do século XIX: Campanha em 1831. Estudos Econômicos, São Paulo, vol. 22, n 1, p. 129151, jan./abr. 1992.

\& LIBBY, Douglas Cole. Caminhos alternativos: escravidão e reprodução em Minas Gerais no século XIX. Estudos Econômicos, São Paulo, vol. 25, n 2, p. 203-233, maio/ago. 1995.

PENA, Eduardo Spiller. Pagens da casa imperial. Jurisconsultos, escravidão e a lei de 1871. Campinas: Editora da Unicamp, 2001.

PEREIRA, Waldick. Cana, café \& laranja. História econômica de Nova Iguaçu. Rio de Janeiro: FGV, 1977.

POPULAÇÃO E FAMÍLIA. São Paulo: CEDHAL/USP/Humanitas, vol. 1, n. 1, jan./jun. 1998.

PRADO JÚNIOR, Caio. Formação do Brasil contemporâneo. São Paulo: Brasiliense, 1972.

PRIORE, Mary del (org.). História das crianças no Brasil. São Paulo: Contexto, 2000.

REIS, João José \& SILVA, Eduardo. Negociação e conflito. A resistência negra no Brasil escravista. São Paulo: Companhia das Letras, 1989. 
REIS, João José. Rebelião escrava no Brasil. A história do levante dos Malês em 1835. São Paulo: Cia das Letras, 2003.

RIOS, Ana Maria Lugão. Família e transição. Famílias negras em Paraíba do Sul, 18721920. Niterói: 1990. Dissertação (Mestrado em História Social)-UFF.

ROCHA, Cristiany Miranda. Histórias de famílias escravas em Campinas ao longo do século XIX. Campinas: 1999. Dissertação (Mestrado em História)-UNICAMP.

. Histórias de famílias escravas. Campinas: Editora da Unicamp, 2004.

RODRIGUES, Jaime. O infame comércio. Propostas e experiências no final do tráfico de africanos para o Brasil (1800-1850). Campinas: Editora da Unicamp, 2000.

RODRIGUES, Nina. Os africanos no Brasil. 7 ed. Brasília: Editora da UnB, 1988.

SAMPAIO, Antônio C. J. de. Magé na crise do escravismo. Sistema agrário e evolução econômica na produção de alimentos. Niterói: 1994. Dissertação (Mestrado em História)UFF.

A família escrava e a agricultura mercantil de alimentos: Magé, 1850-1872. População e Família, São Paulo, vol. 1, n. 1, p. 119-141, janeiro/junho 1998.

- Na encruzilhada do império. Hierarquias sociais e conjunturas econômicas no Rio de Janeiro (c. 1650-c. 1750). Rio de Janeiro: Arquivo Nacional, 2001. 
SAMPAIO, Antônio C. J. de. A produção da liberdade: padrões gerais das manumissões no Rio de Janeiro colonial, 1650-1750. In: FLORENTINO, Manolo (org.). Tráfico, cativeiro e liberdade. Rio de Janeiro: Civilização Brasileira, 2005. p. 287-329.

SCHWARCZ, Lília Moritz. O espetáculo das raças. Cientistas, instituições e questões raciais no Brasil: 1870-1930. 3 ed. São Paulo: Companhia das Letras, 1993.

SCHWARTZ, Stuart. Segredos internos. Engenhos e escravos na sociedade colonial. Trad. Laura Teixeira Motta. 2 ed. São Paulo: Companhia das Letras, 1995.

. Escravos, roceiros e rebeldes. Trad. Jussara Simões. Bauru: EDUSC, 2001. . Padrões de propriedade de escravos nas Américas: novas evidências para o Brasil. Estudos Econômicos, São Paulo, vol. 13, n. 1, p. 259-287, jan./abr. 1983.

SILVA, Ana Rosa Cloclet da. Tráfico interprovincial de escravos e seus impactos na concentração da população na província de São Paulo: século XIX. In: ENCONTRO NACIONAL DE ESTUDOS POPULACIONAIS, 8, 1992, São Paulo, vol. 1. Informações Demográficas. Fecundidade, demografia histórica. São Paulo: ABEP, 1992. p. 341-366.

SILVA, Maria Beatriz Nizza da. Sistema de casamento no Brasil Colonial. São Paulo: T. A. Queiroz/ Edusp, 1984.

História da família no Brasil Colonial. Rio de Janeiro:

Nova Fronteira, 1998.

SIMONATO, Andrea Jácome. A lógica demográfica da empresa escravista no contexto e fim do tráfico externo - uma visão comparativa entre os períodos 18231832 e 1843-1852. Rio de Janeiro: 1994. Monografia (Bacharelado em História)-UFRJ. 
SIMONATO, Andrea Jácome. O parentesco entre escravos no meio rural do Rio de janeiro em 1860. População e Família, São Paulo, vol. 1, n. 1, p. 143-179, jan.jun. 1998.

SLENES, Robert W. The demography and economics of brazilian slavery: 1850-1888. Stanford: 1976. Tese (Doutorado em História)-Stanford University.

. Escravidão e família: padrões de casamento e estabilidade familiar numa comunidade escravista (Campinas, século XIX). Estudos Econômicos, São Paulo, vol. 17, n 2, p. 217-227, maio/ago. 1987.

SLENES, Robert W. Lares negros, olhares brancos: histórias da família escrava no século XIX. Revista Brasileira de História, São Paulo, vol. 8, n. 16, p. 189-203, mar./ago. 1988.

Senhores e subalternos no oeste paulista. In: ALENCASTRO, Luiz

Felipe de. História da vida privada no Brasil. Império: a corte e a modernidade nacional. São Paulo: Cia das Letras, 1997. vol. 2. p. 233-290.

Na senzala, uma flor: as esperanças e recordações na formação da família escrava. Rio de Janeiro: Nova Fronteira, 1999.

SOARES, Mariza de Carvalho. Devotos da cor. Identidade étnica, religiosidade e escravidão no Rio de Janeiro, século XVIII. Rio de Janeiro: Civilização Brasileira, 2000.

SOUZA, Marina de Mello e. Parati: a cidade e as festas. Rio de Janeiro: Editora da UFRJ, 1994.

TEIXEIRA, Heloísa Maria. Reprodução e famílias escravas de Mariana, 1850-1888. São Paulo: 2001. Dissertação (Mestrado em História Econômica)-USP. 
VAINFAS, Ronaldo. Trópicos dos pecados. Moral, sexualidade e inquisição no Brasil. Rio de Janeiro: Nova Fronteira, 1997.

(org.). Dicionário do Brasil Imperial (1822-1889). Rio de Janeiro: Objetiva, 2002.

VALEnTIN, Agnaldo. Nem Minas, nem São Paulo. Economia e demografia na localidade paulista de Apiaí (1732-1835). São Paulo: 2001. Dissertação (Mestrado em História Econômica)-USP.

. Ouro paulista: estrutura domiciliar e posse de escravos em Apiaí (1732 a 1798). Estudos Econômicos, São Paulo, v. 31, n. 3, p. 551-585, jul./set. 2001.

Posse de escravos em Apiaí, São Paulo, 1732 a 1835. São Paulo: FFLCH/USP, 2001.

VASCONCELlOS, Marcia Cristina de. Nas bênçãos de Nossa Senhora do Rosário. Relações familiares entre escravos em Mambucaba, Angra dos Reis, 1830 a 1881. Niterói: 2001. Dissertação (Mestrado em História)-UFF.

. Pais e filhos nos limites da escravidão. São

Paulo: Nativa, 2002.

VENÂNCIO, Renato Pinto. Nos limites da sagrada família. In: VAINFAS, Ronaldo (org.). História e sexualidade no Brasil. São Paulo: Brasiliense, 1983. p. 107-123.

YAKEYA, Denise M. Comércio e Diplomacia: o corpo consular francês na expansão comercial da França para o Brasil no século XIX. Revista Pós-Graduação, Assis, vol. 2, p. 221-235, 1994. 